NIST Special Publication 1142

\title{
The Current State and Recent Trends of the U.S. Manufacturing Industry
}

Douglas S. Thomas

http://dx.doi.org/10.6028/NIST.SP.1142

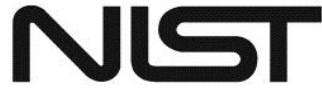

National Institute of Standards and Technology U.S. Department of Commerce 
NIST Special Publication 1142

\section{The Current State and Recent Trends of the U.S. Manufacturing Industry}

Douglas S. Thomas

Applied Economics Office

Engineering Labaratory

http://dx.doi.org/10.6028/NIST.SP.1142

December 2012

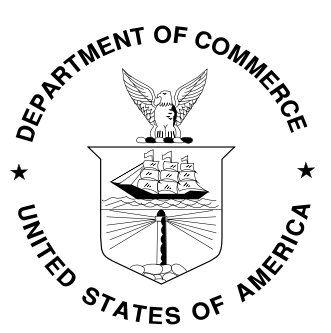

U.S. Department of Commerce Rebecca Blank, Acting Secretary

National Institute of Standards and Technology Patrick D. Gallagher, Under Secretary of Commerce for Standards and Technology and Director 
Certain commercial entities, equipment, or materials may be identified in this document in order to describe an experimental procedure or concept adequately. Such identification is not intended to imply recommendation or endorsement by the National Institute of Standards and Technology, nor is it intended to imply that the entities, materials, or equipment are necessarily the best available for the purpose.

National Institute of Standards and Technology Special Publication 1142 Natl. Inst. Stand. Technol. Spec. Publ. 1142, 150 pages (December 2012) http://dx.doi.org/10.6028/NIST.SP.1142

CODEN: NSPUE2 


\section{Abstract}

This report brings together multiple sources of aggregate manufacturing industry data and industry subsector data to develop a quantitative depiction of the U.S. manufacturing industry. It compares the U.S. manufacturing industry to its international counterparts in order to provide context to domestic activities. This approach promotes a better understanding of the U.S. manufacturing industry and provides an evidence-based depiction of both the industry and its subsectors. Domestic and international data on employment, compensation, output, value added, net income (profit), and research and development expenditures are explored and evaluated. A number of techniques are utilized to compare and analyze these data including input-output analysis. Many of the industry's subsectors are discussed individually with a focus on medium- and hightechnology sectors.

The U.S. produces approximately $18 \%$ of the world's manufactured goods, making it the largest manufacturing nation in the world, according to 2008 United Nations Statistics Division (UNSD) data. This data also shows that U.S. manufacturing growth lags behind that of many countries and is growing slower than the whole of the U.S. economy. Compound annual growth in U.S. manufacturing is below the $20^{\text {th }}$ percentile of 180 nations. Countries such as the United Kingdom, Japan, Canada, France, Germany, Australia, and Italy were among the many countries that had a higher growth rate than the U.S. This corresponds with data from the Bureau of Economic Analysis (BEA) that shows that U.S. manufacturing's average annual ten year growth has declined from around $4 \%$ in 1957 to $-1 \%$ in 2008 . While manufacturing value added is larger in the U.S. than in any other country, U.S. manufacturing per capita has lagged slightly behind some industrialized nations, such as Germany and Japan. At least 20 other nations had a higher manufacturing value added per capita than the U.S. in 2008, according to UNSD data. In 2005, the U.S. had a higher rate of manufacturing businesses exiting the market than entering it while other countries such as Canada had a higher rate of businesses entering the market. Seemingly, this trend has left the U.S. manufacturing industry with one of the lowest numbers of active employer enterprises per capita and having a share of total employment lower than Germany, Italy, Japan, France, Canada, and the United Kingdom. Despite slow growth, U.S. research and development expenditures in manufacturing, both nominal and per capita, are among the highest being greater than Germany, Canada, Australia, and China, according to OECD data. This is complimented by the fact that the U.S. is among the top publishers of scientific and technical journals as well as patent applications, both in nominal and per capita data from the World Bank. Additionally, manufacturing continues to play a significant role in the U.S. economy as it accounts for $23 \%$ of U.S. output according to BEA data and $28 \%$ according to OECD data.

Keywords: Competitiveness; Industry; Manufacturing; Statistics; Technology 


\section{Preface}

This study was conducted by the Applied Economics Office in the Engineering Laboratory at the National Institute of Standards and Technology. The study provides aggregate manufacturing industry data and industry subsector data to develop a quantitative depiction of the U.S. manufacturing industry.

\section{Disclaimer}

Certain trade names and company products are mentioned in the text in order to adequately specify the technical procedures and equipment used. In no case does such identification imply recommendation or endorsement by the National Institute of Standards and Technology, nor does it imply that the products are necessarily the best available for the purpose.

\section{Cover Photographs Credits}

Microsoft Clip Art Gallery Images used in compliance with Microsoft Corporation's non-commercial use policy. 


\section{Acknowledgements}

The author wishes to thank all those who contributed so many excellent ideas and suggestions for this report. Special appreciation is extended to Simon Frechette and Conrad Bock of the Engineering Laboratory's Systems Integration Division and to Frederick Proctor of the Engineering Laboratory's Intelligent Systems Division for their technical guidance, suggestions, and support. Additionally, the author would like to thank economists Stephen Campbell and Dr. Gregory Tassey of the Associate Director for Innovation and Industry Services' Economic Analysis Office for their insight and ideas. Special appreciation is also extended to Dr. David Butry, Dr. Stanley Gilbert, and Dr. Robert Chapman of the Engineering Laboratory's Applied Economics Office for their thorough reviews and many insights and to Ms. Carmen Pardo for her assistance in preparing the manuscript for review and publication. The author also wishes to thank Dr. Nicos Martys, Materials and Structural Systems Division, for his review. 


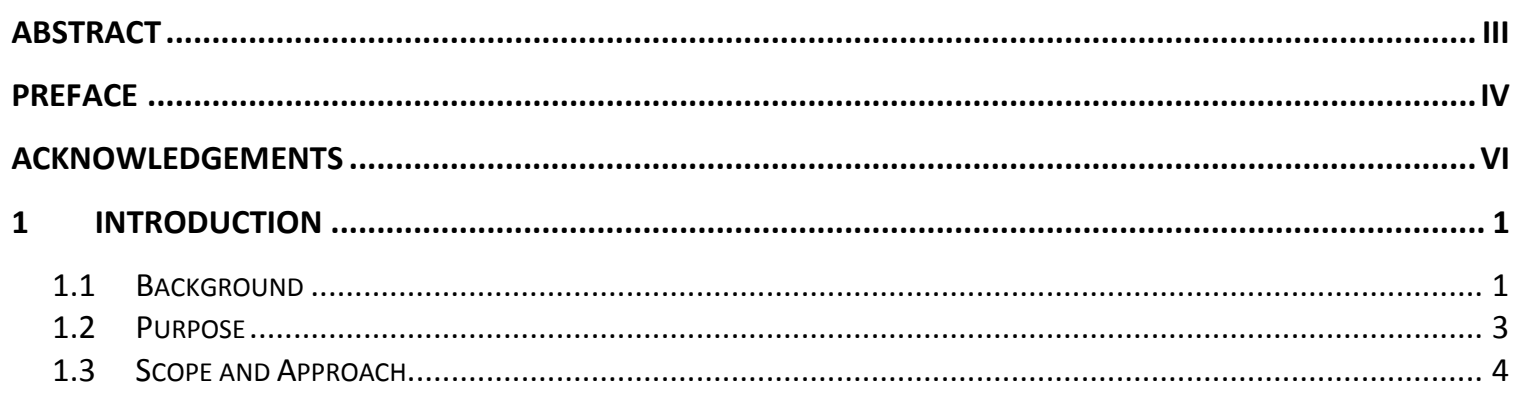

2 MANUFACTURING INDUSTRY STAKEHOLDERS, METRICS, AND DATA .......................................... 7

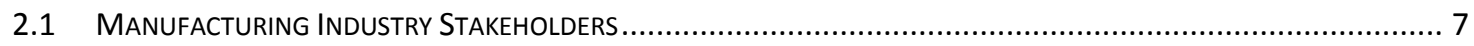

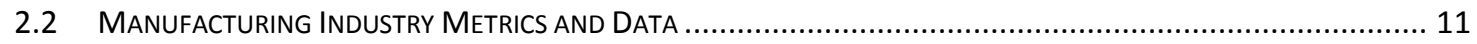

3 INTERNATIONAL DATA: HOW THE U.S. COMPARES TO THE REST OF THE WORLD ........................ 15

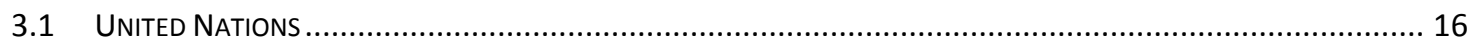

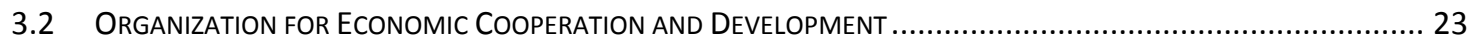

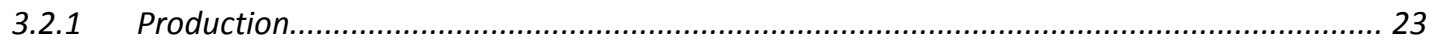

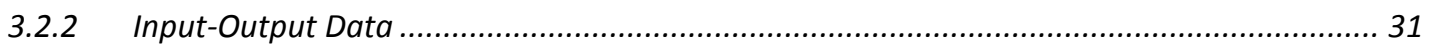

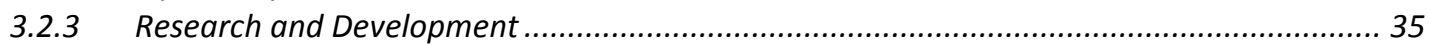

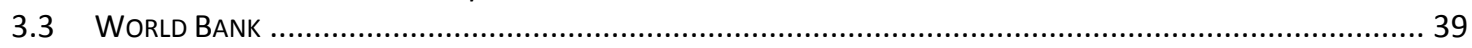

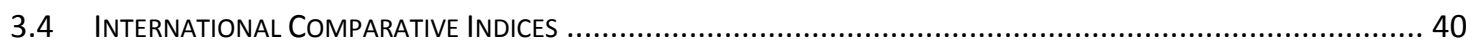

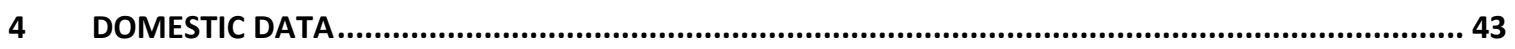

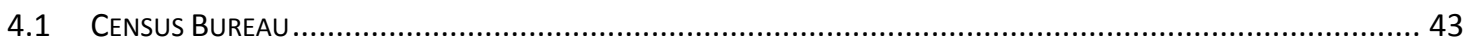

4.1.1 Annual Survey of Manufactures and the Economic Census .............................................. 44

4.1.2 Manufacturers' Shipments, Inventories, and Orders Survey.............................................. 49

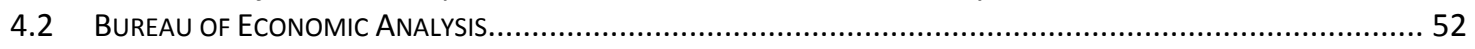

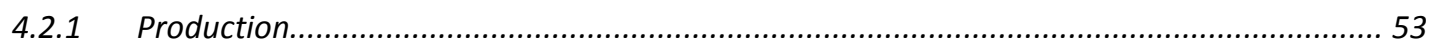

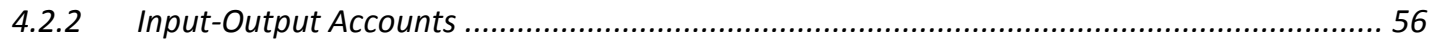

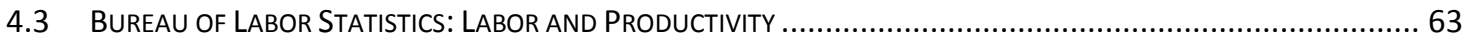

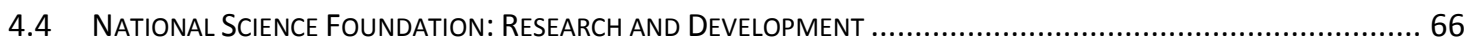

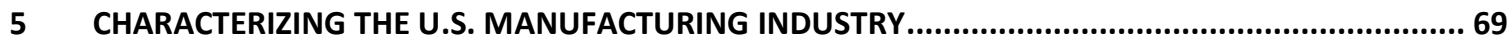

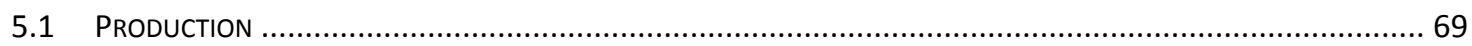

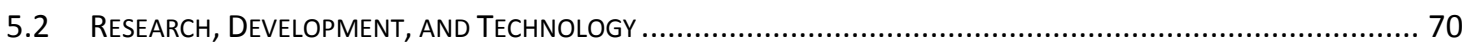

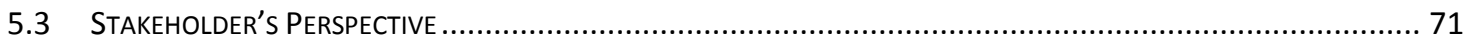

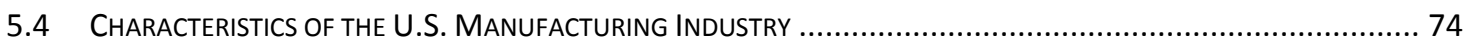

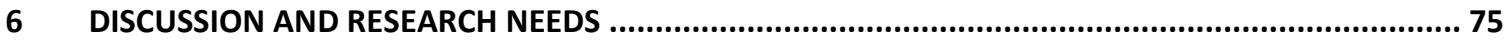

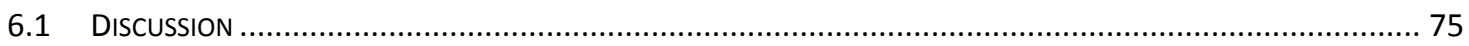

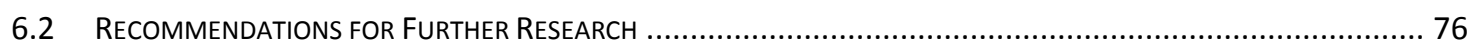

APPENDIX A: GLOBAL COMPETITIVENESS INDEX RANKINGS (WORLD ECONOMIC FORUM) .................... 83

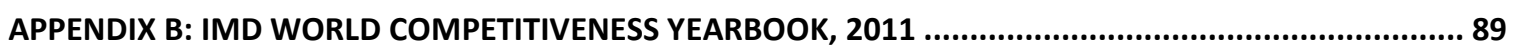

APPENDIX C: ANNUAL SURVEY OF MANUFACTURES, MEDIUM- AND HIGH-TECH SECTORS (2009) ......... 91

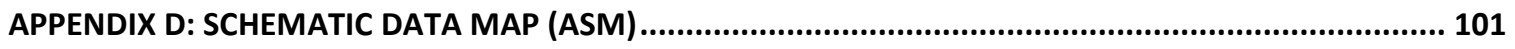

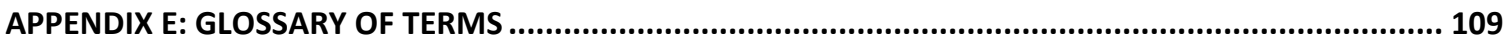




\section{LIST OF FIGURES}

Figure 2.1: Manufacturing Supply Chain ................................................................... 8

Figure 3.1: UNSD Manufacturing GDP by Nation (\$billions 2009).............................. 17

Figure 3.2: UNSD Manufacturing Value Added for 180 Countries, Compound Annual

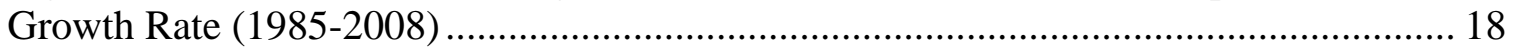

Figure 3.3: UNSD Manufacturing GDP per Capita........................................................ 19

Figure 3.4: UNSD Manufacturing as a Percent of GDP (1970-2008) ............................. 20

Figure 3.5: Selected Manufacturing Subsectors: Value Added and Value Added per

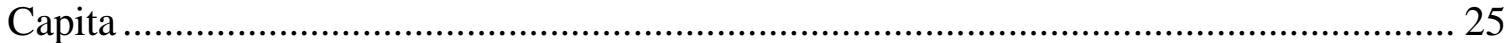

Figure 3.6: U.S. Manufacturing Value Added (excluding ISIC 15-22, 36, and 37) by

Subsector (OECD Structural Analysis Database) .......................................................... 26

Figure 3.7: Manufacturing Share of Employment (OECD SDBS Business Demography

Database)

Figure 3.8: Global Competitiveness Index Ranking (139 countries) by Category, 20102011

Figure 4.1: Value Added and Employment for Select Manufacturing Subsectors, Annual

Survey of Manufactures (adjusted using industry specific PPI)

Figure 4.2: Value Added and Employment for Semiconductor and Other Computer Component Manufacturing

Figure 4.3: Manufacturing Employment and Valued Added, 2009................................ 48

Figure 4.4: Manufacturing as a Percent of GDP (BEA) ………................................... 49

Figure 4.5: Manufacturing Industry Supply Chain, 2009 ……………......................... 50

Figure 4.6: Manufacturing Shipments, 1958-2000 (Manufacturers' Shipments, Inventories, and Orders Survey) ............................................................................... 51

Figure 4.7: Manufacturing Shipments, 1992-2009 (Manufacturers' Shipments,

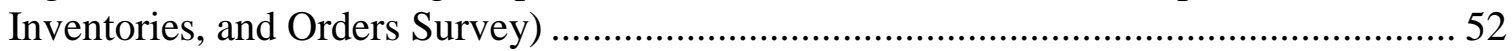

Figure 4.8: U.S. GDP by Industry (\$billions 2009), BEA ............................................. 53

Figure 4.9: 10 Year Moving Average of Annual Growth in the Manufacturing Industry and Ratio of Imported Goods to Manufacturing Value Added........................................ 54

Figure 4.10: Ratio of BEA Value Added to Shipments from the Manufacturers'

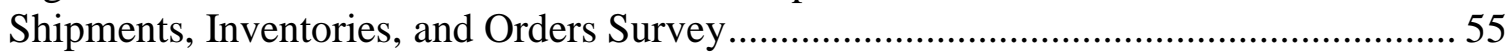

Figure 4.11: Manufacturing GDP (BEA), 1977-2009 ................................................ 55

Figure 4.12: Selected Manufacturing Industries GDP by Industry (BEA), 1986-2009... 56

Figure 4.13: Output per Unit of Labor (aggregate percent increase of BLS Index) ......... 63

Figure 4.14: Manufacturing Employment as a Percent of Total Non-Farm Employment

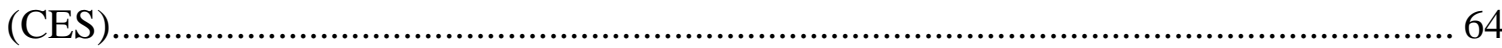

Figure 4.15: Employment in Manufacturing and Select Subsectors, 1919-2010 (Current

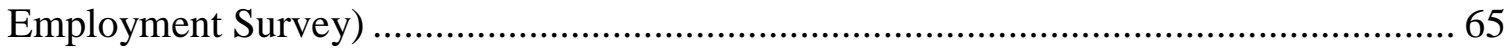

Figure 4.16: Wages in Manufacturing and Select Subsectors, 1919-2010 (Current

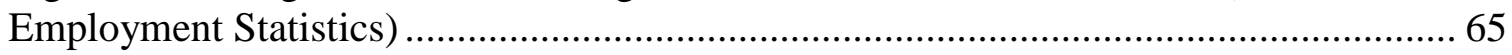

Figure 4.17: Company and Other Research and Development by Industry ..................... 67

Figure 4.18: Company and Other Research and Development by Industry (subsectors of the chemical industry and computer and electronic industry) .............................................6 68

Figure 4.19: Research and Development by Source of Funds .......................................... 68 
Table 2.1: Stakeholders......................................................................................... 9

Table 2.2: Stakeholder's Expected Returns and Associated Metrics ............................... 12

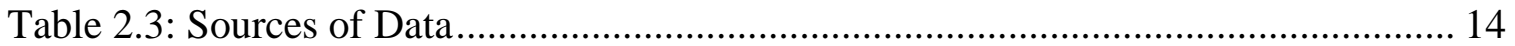

Table 3.1: Annual Wages by Select Manufacturing Subsectors, \$2006 (UNIDO Statistical

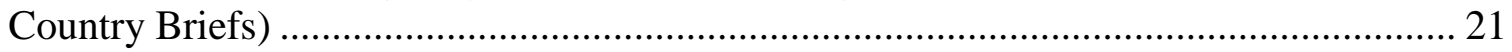

Table 3.2: Detailed Manufacturing Value Added Industry Comparisons, 2006 (UNIDO

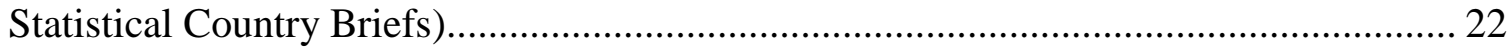

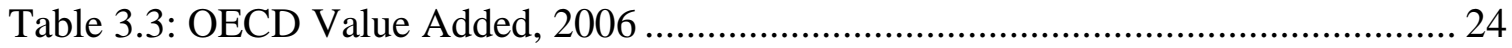

Table 3.4: U.S. Value Added per Capita by Year, Percentile (OECD Structural Analysis

Database) .................................................................................................... 27

Table 3.5: U.S. Rank of Gross Operating Surplus per Dollar of Expenditure (OECD

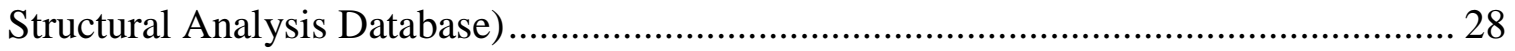

Table 3.6: U.S. Rank of the Ratio of Value Added to Hours of Work (OECD Structural

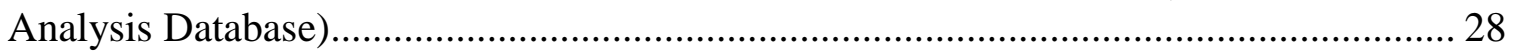

Table 3.7: Wages by Year, Percentile (OECD Structural Analysis Database)................ 29

Table 3.8: Employer Enterprises in Manufacturing (OECD SDBS Business Demography

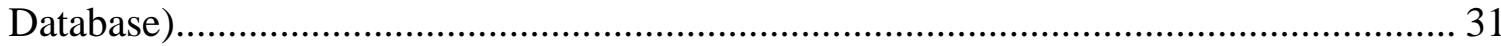

Table 3.9: Value Added from the STAN Input-Output Data........................................ 33

Table 3.10: Compensation, Gross Operating Surplus, and Taxes as a Percent of Value

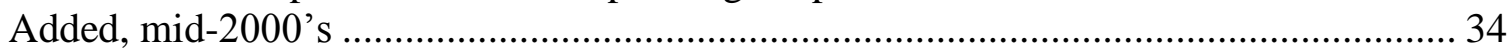

Table 3.11: Input-Output Analysis using OECD STAN Data, mid-2000's ................... 35

Table 3.12: Research and Development Expenditures by Country, 2006 (OECD STAN

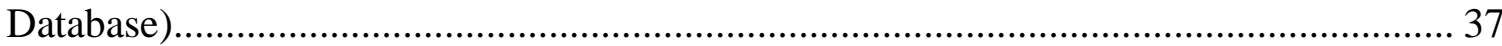

Table 3.13: U.S. Research and Development Expenditures by Year, Percentile (OECD

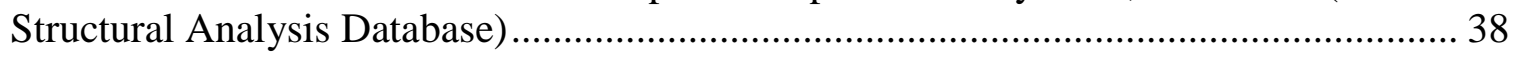

Table 3.14: U.S. Research and Development per Capita by Year, Percentile (OECD

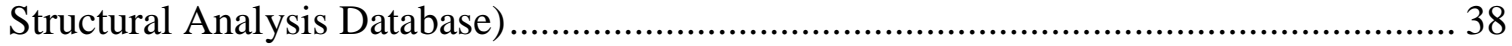

Table 3.15: U.S. Patents (OECD Patent Database) ....................................................... 39

Table 3.16: U.S. Science and Technology Indicators, Percentile (World Bank)............. 40

Table 3.17: U.S. Competitive Industrial Performance Index Rankings (121 countries

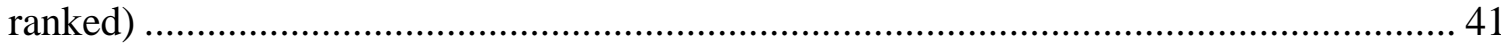

Table 4.1: Subsectors of Manufacturing, Annual Survey of Manufactures 2009 ........... 46

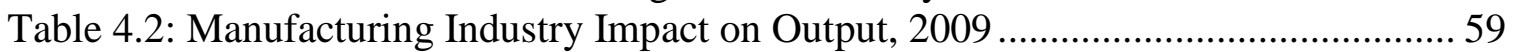

Table 4.3: Products Used by Manufacturing Subsectors (\$millions 2009) ...................... 60

Table 4.4: Manufacturing Products Used by Other Industries (\$million 2009) ............... 61

Table 4.5: Manufacturing Industry Impact on Value Added, 2009 ................................ 62

Reading Figures and Tables: Figures in this report frequently have two images and one legend. The legend applies to both images. Tables frequently have colored bars (red or green). These bars provide comparisons between other figures in the table, often between countries or industries. Red bars signify instances where a lower value is preferred such as rankings (i.e., being $1^{\text {st }}$ is preferred over $31^{\text {st }}$ ). 
ASM - Annual Survey of Manufactures

BEA - Bureau of Economic Analysis

BLS - Bureau of Labor Statistics

BOY - Beginning of Year

CES - Current Employment Statistics

CIP - Competitive Industrial Performance Index

CPI - Consumer Price Index

CPS - Current Population Survey

EIN - Employer Identification Number

EOY - End of Year

EPO - European Patent Office

FDI - Foreign Direct Investment

FOB - Free on Board

GDP - Gross Domestic Product

GNP - Gross National Product

IBRD - International Bank for Reconstruction and Development

IDA - International Development Association

IMD - International Institute for Management Development

IMF - International Monetary Fund

ISIC - International Standard Industrial Classification

NAICS - North American Industry Classification System

NCSES - National Center for Science and Engineering Statistics

NSF - National Science Foundation

OECD - Organization for Economic Co-operation and

Development

PCT - Patent Co-operation Treaty

PEO - Professional Employer Organizations

PPP - Purchasing Power Parity

SDBS - Structural and Demographic Business Statistics

SNA - System of National Accounts

STAN - Structural Analysis Database

UN - United Nations

UNIDO - United Nations Industrial Development Organization

UNSD - United Nations Statistics Division

USPTO - United States Patent and Trademark Office 


\section{Introduction}

\subsection{Background}

The U.S. produces approximately $18 \%$ of the world's manufactured goods, making it the largest manufacturing nation in the world, according to 2008 United Nations Statistics Division (UNSD) data. Medium and high technology goods, as defined by the United Nations Industrial Development Organization (UNIDO), account for $56 \%$ of U.S. manufacturing value added in 2003. ${ }^{1}$ Additionally, the industry impacts $23 \%$ of U.S. output, according to 2009 data from the Bureau of Economic Analysis. Thus, the manufacturing industry is indispensable to the U.S. economy; however, numerous media articles have discussed the decline of U.S. manufacturing with many proposing that the U.S. has lost its competitive edge in manufacturing. ${ }^{2}$ According to industry data, however, it is unclear whether the U.S. manufacturing industry is declining. After controlling for inflation, the industry grew 21\% between 1980 and 2007, as measured in value added from the Bureau of Economic Analysis; thus, the industry is actually growing in terms of the value of the goods being produced. It is likely that at least some of this concern is due to changes in manufacturing employment, ${ }^{3}$ which, in recent years, has steadily decreased. ${ }^{4}$ This trend, however, pervades internationally and is, to some extent, due to significant increases in productivity. Declining employment is easily observed by the average individual. Stories of lost jobs, unemployed workers, and outsourcing overseas are more common news stories than increases in productivity. While employment has decreased, many people would be surprised to learn that General Motors employed over 96,000 workers in the U.S. during $2008^{5}$ or that some business consultants are advising companies to locate manufacturing plants in the U.S. because it is more cost effective. ${ }^{6,7}$ And, while there has been concern that semiconductor fabrication plants are being moved overseas, ${ }^{8}$ Intel has at least 6 semiconductor fabrication plants in the U.S. with one of them being built as recently as 2007. As of 2010 , other companies are building or planning to build additional fabrication plants in the U.S. ${ }^{9}$ This does not mean that the U.S. manufacturing industry does not have deficiencies, but it does mean that the current state and recent trends of the U.S. industry

\footnotetext{
${ }^{1}$ UNIDO Strategic Research Database. Competitive Industrial Performance Index. 2003. <http://www.unido.org/index.php?id=5058>

2 Sirkin, Harold L. "Made in the USA Still Means Something." Bloomberg Businessweek. April 10, 2009. <http://www.businessweek.com/managing/content/apr2009/ca20090410_054122.htm>

${ }^{3}$ US-China Business Council. “US Manufacturing: Dying... Or Still Going Strong?” 2006.

<https://www.uschina.org/public/documents/2006/09/us-manufacturing.pdf>

${ }^{4}$ Congressional Budget Office. "Factors Underlying the Decline in Manufacturing Employment Since 2000." December 23, 2008. <http://www.cbo.gov/ftpdocs/97xx/doc9749/12-23-Manufacturing.pdf>

${ }^{5}$ Carbaugh, Robert J. International Economics. (Mason, OH: South Western Cengage Learning, 2011$), 78$.

${ }^{6}$ Economist. "The Dwindling Allure of Building Factories Offshore." May 12, 2011.

<http://www.economist.com/node/18682182?fsrc=rss\&story_id=18682182>

${ }^{7}$ Sirkin, Harold L. "Manufacturers: Rethink Your Bond with China." Bloomberg Businessweek. February 13, 2009. <http://www.businessweek.com/managing/content/feb2009/ca20090213_657126.htm>

${ }^{8}$ Center for Public Policy Innovation. "The Decline in Semiconductor Manufacturing in the United States." June 2010. <http://cppionline.org/docs/The-Decline-of-Semiconductor-Manufacturing.pdf>

${ }^{9}$ SEMI. Semiconductor, LED, and MEMS Fabs and Foundries. <http://www.semi.org/en/>
} 
are not obviously apparent. In addition to employment trends, there are numerous other worries concerning the industry: research and development expenditures, ${ }^{10,11}$ U.S. labor costs, globalization, availability of qualified workers, ${ }^{12}$ U.S. corporate taxes ${ }^{13}$ the ability to acquire funding for business ventures, location of industry supply chains, ${ }^{14}$ and lower growth rates to name a few.

Many industry experts have endorsed media claims in suggesting that the U.S. manufacturing industry is losing its competitive edge; however, many disagree on what it means for a nation to be competitive and what metrics are appropriate for measuring competitiveness. Commentary by Tassey, Krugman, and others has illustrated divergent views in regard to competitiveness. ${ }^{15,16,17,18,19,20}$ This makes it all the more important to track a variety of aspects of the industry. This can be challenging, however, as the industry can appear to be contracting or expanding depending on what aspect of the industry one is examining and depending on the methods used to adjust industry data. Employment, for example, has steadily decreased, ${ }^{21}$ while value added has increased.

Over time manufacturing processes have changed dramatically. Robotic arms and other machinery have radically changed the manufacturing environment. For instance, just a few decades ago a company such as Standard Motor Products, which produces replacement parts for car engines, had a number of employees who were illiterate. Today, many of the employees at Standard Motor Products not only need to be able to read, they

\footnotetext{
${ }^{10}$ Tassey Gregory. "Rationales and Mechanisms for Revitalizing U.S. Manufacturing R\&D Strategies." Journal of Technology Transfer. 35 (2010): 283-333.

${ }^{11}$ Pisano, Gary P. and Willy C. Shih. Restoring American Competitiveness. Harvard Business Review. July-August (2009).

${ }^{12}$ Committee on Prospering in the Global Economy of the 21st Century: An Agenda for American Science and Technology, National Academy of Sciences, National Academy of Engineering, Institute of Medicine.

"Rising Above the Gathering Storm: Energizing and Employing America for a Brighter Economic Future." National Academies Press. <http://www.nap.edu/catalog.php?record_id=11463>

${ }^{13}$ Engardio, Pete. "Can the Future Be Built in America." Bloomberg Businessweek. April 26, 2009

<http://www.businessweek.com/magazine/content/09_38/b4147046115750.htm>

${ }^{14}$ Bhatnagar, Rohit and Amrik S. Sohal. "Supply Chain Competitiveness: Measuring the Impact of Location Factors, Uncertainty and Manufacturing Practices." Technovation. 25 (2005): 443-456.

15 Tassey Gregory. "Rationales and Mechanisms for Revitalizing U.S. Manufacturing R\&D Strategies." Journal of Technology Transfer. 35 (2010): 283-333.

${ }^{16}$ Krugman, Paul. "Making Sense of the Competitiveness Debate." Oxford Review of Economic Policy. Vol. -12 no. 3 (1996): 17-25.

${ }^{17}$ Krugman, Paul. "Competitiveness, A Dangerous Obsession.” Foreign Affairs. Vol 73. Num 2. March/April (1994): 28-44.

${ }^{18}$ US-China Business Council. “US Manufacturing: Dying... Or Still Going Strong?” 2006.

<https://www.uschina.org/public/documents/2006/09/us-manufacturing.pdf>

${ }^{19}$ World Economic Forum. The Global Competitiveness Report. 2010-2011.

<http://www3.weforum.org/docs/WEF_GlobalCompetitivenessReport_2010-11.pdf>

${ }^{20}$ Toder, Eric. “International Competitiveness: Who Competes Against Whom and for What?" Tax Policy

Center: Urban Institute and Brookings Institution. January (2012).

<http://www.taxpolicycenter.org/UploadedPDF/412477-international-competitiveness.pdf>

${ }^{21}$ Congressional Budget Office. "Factors Underlying the Decline in Manufacturing Employment Since

2000." December 23, 2008. <http://www.cbo.gov/ftpdocs/97xx/doc9749/12-23-Manufacturing.pdf>
} 
need to know the computer language of the machinery producing the parts. ${ }^{22,23}$ The increase in productivity that is often the result of these changes means fewer employees are needed to make the same products, possibly resulting in lower employment levels in manufacturing. And, while American manufacturing efficiency is improving, other nations have been developing and improving their own manufacturing industries. Emerging economies such as China have gone from producing some manufactured goods to producing a significant amount of goods. Understanding the current state and recent trends of the U.S. manufacturing industry in light of these issues is difficult. Tassey's "Rationales and Mechanisms for Revitalizing U.S. Manufacturing R\&D Strategies" 24 and the commentaries that follow it, illustrate that determining the current and future state of U.S. manufacturing is controversial. Some experts have stated that U.S. multinationals have "abandoned" the U.S. and their global expansion "tends to "hollow out" U.S. operations while exporting jobs abroad. Others counter that operations and investment of U.S. multinationals are highly concentrated in the U.S. and maintain a large presence while increasing overseas activities. ${ }^{25,26,27}$ Determining the current state and recent trends of the U.S. manufacturing industry is complex and there is a need for an assemblage of data that measures components of the industry.

\subsection{Purpose}

The purpose of this report is to track domestic manufacturing activity in order to develop a quantitative depiction of U.S. manufacturing in context of the global industry. The report first discusses the primary data available on the industry, both nationally and internationally, and then provides a synopsis of the data. As displayed in Table 2.3, numerous sources of data are used to depict the manufacturing industry, including data from the Organization for Economic Co-operation and Development (OECD), United Nations (UN), and U.S. Bureau of Labor Statistics (BLS). There are two aspects that can be discussed that relate to the U.S. manufacturing industry. The first includes the trends and current state of the industry. This includes the quality and quantity of production along with expenditures on research and development activities. The second is the environment in which the manufacturing industry must operate. This includes taxes, regulations, infrastructure, the labor market, and current economic conditions among other things. This report largely focuses on the current state and recent trends of U.S.

\footnotetext{
22 Davidson, Adam. "The Transformation of American Factory Jobs, In One Company." NPR. January 13, 2012. <http://www.npr.org/blogs/money/2012/01/13/145039131/the-transformation-of-american-factoryjobs-in-one-company? $\mathrm{ft}=1 \& \mathrm{f}=100>$

${ }^{23}$ Davidson, Adam. "Making It in America." The Atlantic. January/February (2012). <http://www.theatlantic.com/magazine/archive/2012/01/making-it-in-america/8844/?single_page=true>

${ }^{24}$ Tassey Gregory. "Rationales and Mechanisms for Revitalizing U.S. Manufacturing R\&D Strategies." Journal of Technology Transfer. 35 (2010): 283-333.

${ }^{25}$ Slaughter, Matthew J. "How U.S. Multinational Companies Strengthen the U.S. Economy." United States Council for International Business. (March 2010). <http://www.uscib.org/docs/foundation_multinationals.pdf>

${ }^{26}$ National Science Foundation. “Asia’s Rising Science and Technology Strength.” May 2007. <http://www.nsf.gov/statistics/nsf07319/>

${ }^{27}$ Sirkin, Harold L. "Made in the USA Still Means Something." Bloomberg Businessweek. April 10, 2009. <http://www.businessweek.com/managing/content/apr2009/ca20090410_054122.htm>
} 
manufacturing domestically and as compared to its international counterparts such as major trading partners and those countries that are often considered as competitors.

\subsection{Scope and Approach}

This report brings together multiple datasets on the current state of the U.S. manufacturing industry. It then uses various strategies to compare these data internationally to develop a quantitative depiction of the U.S. manufacturing industry in context of its international counterparts. Data and information on the manufacturing industry is extensive. Understanding these resources and identifying the relevant statistics that can be extracted from them requires both familiarity with and an understanding of industry data. In order to understand the current state and recent trends in manufacturing, data is needed on both the domestic and international manufacturing industries. There are many sources of information that provide data on individual nations. Unfortunately, identifying, adjusting, and accumulating these data would require a considerable amount of time and resources. Therefore, this report relies on sources that provide data on multiple nations to make international comparisons. However, in depth data on the U.S. is used to understand the details of the domestic manufacturing industry. In order to make meaningful comparisons of international data a variety of factors, such as population and exchange rates, need to be considered. For instance, the U.S. may be the largest producer of manufactured goods in the world; however, it may not be the largest on a per capita basis. These types of issues are important in examining U.S. manufacturing.

National economies are often compared to companies competing for market share. This is a common analogy made when discussing the U.S. manufacturing industry; unfortunately, this comparison can be rather misleading. ${ }^{28,29,30,31,32}$ A national economy is the primary supplier of goods and services to its labor force while a single company, generally, is not the primary supplier of goods and services to its employees. Additionally, a national economy provides the income for the majority of the nation's consumers while a business, generally, does not provide the income for the majority of its customers. Moreover, a national economy represents a system of exchange in which a company operates as one entity of that system. Companies can go out of business while

\footnotetext{
${ }^{28}$ Krugman, Paul R. "Making Sense of the Competitiveness Debate." Oxford Review of Economic Policy. Vol 12, no. 3 (1996): 17-25. Paul Krugman won the 2008 Nobel Memorial Prize in Economic Sciences for his work on international trade and economic geography.

${ }^{29}$ Krugman, Paul R. "Competitiveness, A Dangerous Obsession.” Foreign Affairs. Vol 73. Num 2. March/April (1994): 28-44.

${ }^{30}$ The World Economic Forum defines competitiveness of a nation as "the set of institutions, policies, and factors that determine the level of productivity of a country." This definition relates to productivity and is not consistent with the idea of countries competing for market share. World Economic Forum. The Global Competitiveness Report. 2010-2011.

<http://www3.weforum.org/docs/WEF_GlobalCompetitivenessReport_2010-11.pdf〉

${ }^{31}$ Porter, Michael E. The Competitive Advantage of Nations. $1^{\text {st }}$ ed. (New York: The Free Press, 1990).

${ }^{32}$ Porter asserts that competitiveness is measured by productivity and that measuring a country's competitiveness as its share of world markets is "deeply flawed." Porter, Michael E. "Building the Microeconomic Foundations of Prosperity: Findings from the Business Competitiveness Index." In Porter, Michael E., Klaus Schwab, Xavier Sala-i-Martin, and Augusta Lopez-Claros. The Global Competitiveness Report 2003-2004. (New York: Oxford University Press, 2004).
} 
nations do not. Domestic demand for goods and services constitutes a great proportion of the demand for a nation's domestically-produced products where the demand for goods and services from a company is primarily external. In addition to these analogies, frequently, anecdotal observations are used to characterize the manufacturing industry; ${ }^{33}$ however, the insight from these types of observations is somewhat limited, as the manufacturing industry includes hundreds of thousands of establishments with millions of employees making trillions of dollars worth of goods. Anecdotal observations provide a limited narrow scope of the industry that does not necessarily reflect or apply to the industry as a whole. This report will largely avoid these types of comparisons and anecdotes as they can add confusion to complex matters. This approach reduces the possibility of mischaracterizing the industry and provides an evidence-based depiction of the manufacturing industry and its subsectors.

Although this report depicts the manufacturing industry with a focus on medium- and high-tech industry, the sectors included in these categories are only generally identified. There does not seem to exist a well-established criteria for identifying what types of manufacturing are high-tech, medium-tech, or low-tech; however, the definition by the OECD is commonly used, which utilizes research and development intensities. ${ }^{34}$ It is often the case that authors refer to medium- and high-tech manufacturing and simply specify the industries to which they are referring. For the purpose of this report, mediumtech manufacturing includes chemical, mechanical, and electronic equipment manufacturing while high-tech manufacturing includes computer and related product manufacturing, which is consistent with the definition provided in the RAND Technical Report on High Technology Manufacturing and with the definition used by the United Nations Industrial Development Organization. ${ }^{35}$ This broader definition allows for an examination of medium- and high-tech industries while also being able to examine the manufacturing industry as a whole. It also allows for a more general comparison between countries, as international data is often limited.

This report begins by identifying stakeholders and metrics for the manufacturing industry. It is then followed with a presentation of international and domestic data relating to stakeholder's vested interests. International data tends to be broader in nature, which allows for some comparison of U.S. manufacturing to its international counterparts. Although limited in nature, this comparison provides critical context in which to view the U.S. manufacturing industry and its subsectors. In contrast, domestic data is much more detailed in nature, which allows for a more comprehensive discussion on medium and high tech manufacturing. Following the chapters on international and domestic data is a chapter that discusses the data as a whole in order to characterize the

\footnotetext{
${ }^{33}$ Greenwald, Bruce C.N. and Judd Kahn. Globalization: The Irrational Fear that Someone in China will Take Your Job. (Hoboken, NJ: John Wiley \& Sons 2009).

${ }^{34}$ OECD. "Measuring Globalisation: OECD Handbook on Economic Globalisation Indicators.” May 2005. <http://www.oecd-ilibrary.org/economics/measuring-globalisation-oecd-handbook-on-economicglobalisation-indicators-2005_9789264108103-en >

${ }^{35}$ Kelley, Charles, Mark Wang, Gordon Bitko, Michael Chase, Aaron Kofner, Julia Lowell, James Mulvenon, David Ortiz, and Kevin Pollpeter. "High-Technology Manufacturing and U.S.

Competitiveness.” RAND Technical Report. March 2004.

<http://www.rand.org/pubs/technical_reports/2004/RAND_TR136.pdf>
} 
U.S. manufacturing industry. The final chapter discusses data needs. The report includes five appendices. Appendix A and Appendix B present two competitiveness indices.

Appendix $\mathrm{C}$ and Appendix D provide detailed data from the Annual Survey of Manufactures while Appendix E contains a glossary of terms. 


\section{Manufacturing Industry Stakeholders, Metrics, and Data}

To track the current state and recent trends in the U.S. manufacturing industry it is necessary to determine what types of data are relevant and provide some context for the data. There are many datasets that track the U.S. manufacturing industry, but they do not all have equal importance. This report identifies manufacturing industry stakeholders and tracks stakeholder costs and benefits. To provide context to the level of costs and benefits, they are compared to their international counterparts.

Individual manufacturing stakeholders are affected by the industry in different ways. Therefore, it is useful to identify individual stakeholders and classify them into stakeholder groups. This classification can then be used to identify the primary investment each stakeholder has in the manufacturing industry along with their expected return. Stakeholders evaluate benefits and costs of manufacturing industry investments purely from their "stakeholder" point of view; therefore, it is important to identify each stakeholder's investment and expected return. These "points of view" can provide some guidance as to what metrics might be used to characterize the manufacturing industry.

\subsection{Manufacturing Industry Stakeholders}

There are a number of stakeholders for the manufacturing industry. The most direct and obvious ones are the owners and employees; these are the individuals directly responsible for production. As seen in the manufacturing supply chain in Figure 2.1, there are many suppliers of goods and services that also have a stake in the industry; these include resellers, providers of transportation and warehousing, raw material suppliers, suppliers of intermediate goods, and suppliers of professional services. The items in the figure colored in blue represent suppliers of services, computer hardware, software, and other costs. Gold represents refuse removal, intermediate goods, and recycling while orange represents machinery, structures, and compensation with red being the repair of the machinery and structures. Green represents the suppliers of materials. These items all feed into the design and production of manufactured goods which are inventoried and/or shipped. The depreciation of capital and net income are also included in the figure, which affect the market value of shipments. In addition to the stakeholders in the figure, there are also public vested interests, the end users, and financial service providers.

As seen in Table 2.1, stakeholders may have a direct investment in manufacturing, such as industry owners and employees, or an indirect investment through supply chains or industry outputs. Each stakeholder is associated with a primary form of investment. For example, employees invest their labor while owners invest land and capital. Owners often have labor and/or intellectual property invested as well; however, their primary investment is in the form of land and capital as seen in Table 2.1. Each stakeholder has invested these items with the expectation of receiving compensation or a return on investment. Employees, for instance, expect to be compensated for their labor and owners 
Figure 2.1: Manufacturing Supply Chain

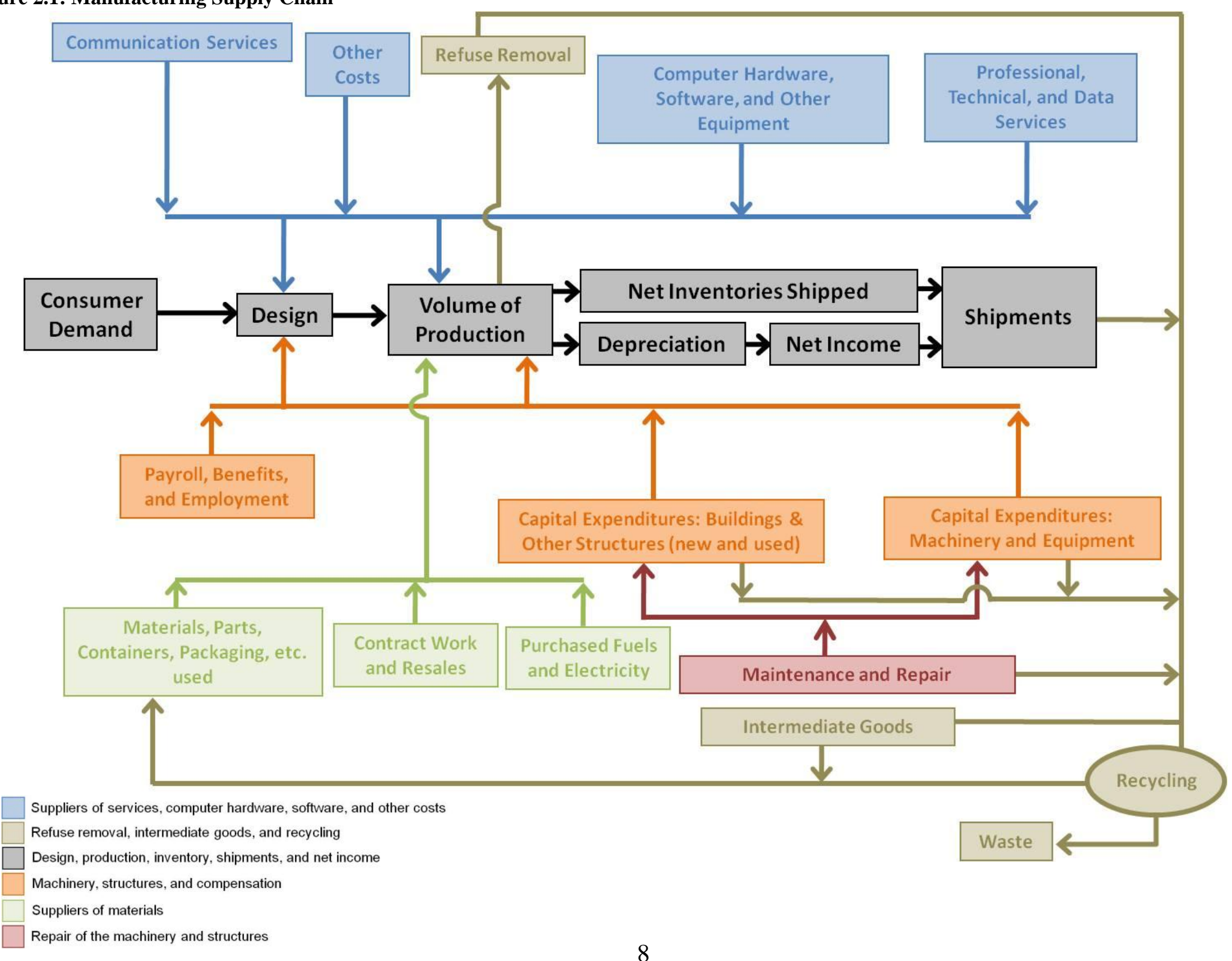




\section{Table 2.1: Stakeholders}

\begin{tabular}{|c|c|c|c|}
\hline Stakeholders & Affiliation & Primary Investment & Expected Return \\
\hline Owners & Private Producers & Land, Capital Goods, and Financial Capital & Profit From Sales \\
\hline Employees (manufacturing industry and suppliers) & Laborers & Labor & Income \\
\hline Resellers & Private Distributer & Land, Capital Goods, and Labor & Profit From Markup \\
\hline Retailers & Private Distributer & Land, Capital Goods, and Labor & Profit From Markup \\
\hline Wholesalers & Private Distributer & Land, Capital Goods, and Labor & Profit From Markup \\
\hline Standards and Codes Organizations & Public/Private Interest & Labor and Intellectual Property & Economic Success \\
\hline Transportation and Warehousing & Support Service & Land, Capital Goods, and Labor & Profit From Fees \\
\hline Air Transportation Providers & Transportation & Land, Capital Goods, and Labor & Profit From Fees \\
\hline Ground Transportation Providers & Transportation & Land, Capital Goods, and Labor & Profit From Fees \\
\hline Warehousing and Storage Providers & Storage Facility & Land and Capital Goods & Profit From Fees \\
\hline Professional Societies & Public/Private Support Services & Labor and Intellectual Property & Economic Success and Profit from Fees \\
\hline Finance Services & Insurance and Finance & Financial Capital & Profit From Fees \\
\hline Insurance Providers & Insurance & Financial Capital & Profit From Fees \\
\hline Health and Medical Insurance Providers & Insurance & Financial Capital & Profit From Fees \\
\hline Financiers & Financier & Financial Capital & Capital Gains \\
\hline Public Vested Interests & Public & Labor and Financial Capital & Economic Success \\
\hline Policy Makers & Public & Labor and Financial Capital & Economic Success \\
\hline Tax Payers & Public & Financial Capital & Economic Success \\
\hline Industry Suppliers & Public/Private Suppliers & Land, Capital Goods, and Labor & Profit \\
\hline Mining Material Suppliers & Private Suppliers & Land, Capital Goods, and Labor & Profit From Sales \\
\hline Agriculture Product Suppliers & Private Suppliers & Land, Capital Goods, and Labor & Profit From Sales \\
\hline Electric Utility Suppliers & Private Suppliers & Land, Capital Goods, and Labor & Profit From Sales \\
\hline Water Utility Suppliers & Public/Private Suppliers & Land, Capital Goods, and Labor & Profit From Sales \\
\hline Natural Gas Suppliers & Private Suppliers & Land, Capital Goods, and Labor & Profit From Sales \\
\hline Facility Construction Providers & Private Suppliers & Land, Capital Goods, and Labor & Profit From Sales \\
\hline Maintenance and Repair Providers & Private Suppliers & Land, Capital Goods, and Labor & Profit From Sales \\
\hline Communication Services Providers & Private Support Services & Land, Capital Goods, and Labor & Profit From Fees \\
\hline Other Fuel Suppliers & Private Suppliers & Land, Capital Goods, and Labor & Profit From Sales \\
\hline Refuse Removal Service Providers & Private Support Services & Land, Capital Goods, and Labor & Profit From Fees \\
\hline Professional Services & Public/Private Support Services & Land, Capital Goods, Labor, and Intellectual Property & Profit From Fees \\
\hline Legal Service Providers & Public/Private Support Services & Labor & Profit From Fees \\
\hline Information Service Providers & Private Support Services & Land, Capital Goods, and Labor & Profit From Fees \\
\hline Research Organizations & Public/Private Suppliers & Labor and Intellectual Property & Profit From Fees \\
\hline Accounting Service Providers & Private Support Services & Labor & Profit From Fees \\
\hline Engineering Service Providers & Private Support Services & Labor and Intellectual Property & Profit From Fees \\
\hline Computer Service Providers & Private Support Services & Labor & Profit From Fees \\
\hline Scientific and Technical Service Providers & Private Support Services & Labor and Intellectual Property & Profit From Fees \\
\hline Advertisers & Private Support Services & Labor and Intellectual Property & Profit From Fees \\
\hline Other Professional Services & Private Support Services & Labor and Intellectual Property & Profit From Fees \\
\hline Consumers & End User & Product Purchasing Price & Final Product Utilization \\
\hline
\end{tabular}


expect to receive a profit. There are six different categories of assets used in Table 2.1 that can be vested into the industry: financial capital, capital goods, land, labor, intellectual property, and the end users purchasing price. A successful industry might be considered one that has a suitable magnitude of production that results in competitive net benefits for its stakeholders. The expected returns from the industry include profits from sales, markup, or fees; income; industry success; capital gains; and utility from the final use of the product. The expected returns for each stakeholder are categorized in Table 2.1 .

\section{Summary of Primary Investments}

Land: Naturally-occurring goods such as water, air, soil, mineral, and flora used in the production of products (i.e., the totality of goods or services that a company makes available).

Labor: Human effort used in production, which includes technical and marketing expertise.

Capital Goods: Human made goods used in the production of products.

Financial Capital: Funds provided by investors to purchase capital goods for production of products.

Intellectual Property: Ideas, trademarks, copyrights, trade secrets, and patents used to produce products

Purchasing Price: Market value of products sold

\section{Summary of Expected Returns}

Profit from sales: The financial benefit realized when revenues exceed costs and taxes for a product.

Capital Gains: An increase in the value of a capital asset

Income: Compensation for an individual's service or labor

Profit from Markup: The difference between the cost of a product and its selling price.

Economic Success: A constant and suitable magnitude of production resulting in competitive benefits (profits, capital gains, income, and product utilization) for an industry's stakeholders.

Profit from Fees: The financial benefit realized when revenues exceed costs and taxes for a service. 
Final Product Utilization: The utility gained from the end user of a product.

\subsection{Manufacturing Industry Metrics and Data}

As previously discussed, a successful industry might be considered one that has a suitable magnitude of production that results in competitive net benefits for its stakeholders; however, measuring the magnitude of production as well as the benefits for stakeholders is complicated. It is not clear what level of production is a suitable magnitude of production. A suggested approach is to compare U.S. production to production in other developed and emerging economies, which will provide context for U.S. levels of production. For example, the decline of U.S. production of product $\mathrm{x}$ may appear as though U.S. manufacturing is moving to other nations; however, production of product $\mathrm{x}$ may be declining globally and may have little to do with the health of the U.S. manufacturing industry. Alternatively, the U.S. may be declining in production of product $x$, but is increasing its production of product $y$ in its place. In light of these possibilities it is important to determine the context of production levels of U.S. manufacturing.

In addition to measuring production levels, it is also useful to measure stakeholder's costs and benefits. These costs and benefits, like production levels, also require context and comparison to other developed and emerging economies. Furthermore, there are many stakeholders involved, as seen in Table 2.1. Each stakeholder has costs and benefits that may or may not have well-developed metrics and available data. Furthermore, the data must be separated to reflect national and international costs and benefits. For example, in order to examine retailer's and wholesaler's costs and benefits from the U.S. manufacturing industry, the costs and benefits to retailers and wholesalers of domestically produced products must be separated from products produced abroad. In many instances, this type of data is not fully developed; however, there are some estimates that can be made using Leontief's input-output model. ${ }^{36}$ As seen in Table 2.2, there are a number of metrics available for each stakeholder's benefits and costs. In regards to manufacturing, several types of expected returns have well established datasets that can be utilized. The remaining ones must often be measured using indirect metrics.

There are three aspects of U.S. manufacturing data to consider: (1) how the current industry compares to other countries, (2) the trends in the domestic industry, and (3) the industry trends compared to other countries trends. A number of data sets must be utilized to make these comparisons; however, the various data sets available are not all published in the same format. International data tends to be in the International Standard Industrial Classification (ISIC) version 3.1, a revised United Nations system for classifying economic data. Manufacturing is broken into 23 major categories (ISIC 15 through 37) with additional subcategories. For the purposes of this report, categories 15 through 22 are often aggregated; these include food, beverages, tobacco, textiles, apparel,

\footnotetext{
${ }^{36}$ Miller, Ronald E. and Peter D. Blair. Input-Output Analysis: Foundations and Extensions. (New York: Cambridge University Press, 2009): 16.
} 
Table 2.2: Stakeholder's Expected Returns and Associated Metrics

\begin{tabular}{|c|c|c|c|}
\hline Expected Return & Description & Contributing factors & Primary Metrics \\
\hline Profit from sales (owners) & Revenue less production costs & $\begin{array}{l}\text { Revenue (sales) } \\
\text { Labor costs and/or wages } \\
\text { Cost of land } \\
\text { Cost of capital } \\
\text { Productivity }\end{array}$ & $\begin{array}{l}\text { Sales } \\
\text { Labor costs and/or wages } \\
\text { Capital expenditures } \\
\text { Value added per expenditure dollar } \\
\text { Value added per unit of labor } \\
\text { Productivity indices }\end{array}$ \\
\hline Capital Gains & $\begin{array}{l}\text { Compensation for the use of } \\
\text { assets }\end{array}$ & Rate of return & Interest rates \\
\hline Income & $\begin{array}{l}\text { Compensation for labor } \\
\text { (manufacturing industry and } \\
\text { suppliers) }\end{array}$ & Productivity & $\begin{array}{l}\text { Labor costs and/or wages } \\
\text { Value added per unit of labor } \\
\text { Productivity indices } \\
\text { Number of employed workers }\end{array}$ \\
\hline Profit from Markup & Market selling price less cost & $\begin{array}{l}\text { Costs } \\
\text { Sales }\end{array}$ & $\begin{array}{l}\text { Costs } \\
\text { Sales }\end{array}$ \\
\hline Economic Success & $\begin{array}{l}\text { Levels of production and } \\
\text { productivity that result in } \\
\text { economic prosperity }\end{array}$ & $\begin{array}{l}\text { Production } \\
\text { Productivity } \\
\text { Product quality } \\
\text { Technological intensity }\end{array}$ & $\begin{array}{l}\text { Industry value added } \\
\text { Subsector value added } \\
\text { Research and development expenditures } \\
\text { Innovation metrics (patents and journal articles) } \\
\text { Productivity } \\
\text { Product quality metrics }\end{array}$ \\
\hline $\begin{array}{l}\text { Profit from fees and sales by } \\
\text { non-manufacturing industries }\end{array}$ & $\begin{array}{l}\text { Profit (revenue less production } \\
\text { costs) from products purchased } \\
\text { from non-manufacturing } \\
\text { industries }\end{array}$ & $\begin{array}{l}\text { Revenue (sales) } \\
\text { Labor costs and/or wages } \\
\text { Cost of land } \\
\text { Cost of capital } \\
\text { Productivity }\end{array}$ & $\begin{array}{l}\text { Sales } \\
\text { Labor costs and/or wages } \\
\text { Capital expenditures } \\
\text { Value added per expenditure dollar } \\
\text { Value added per unit of labor } \\
\text { Productivity indices } \\
\text { Value of products supplied }\end{array}$ \\
\hline Final product utilization & Utility & $\begin{array}{l}\text { Price } \\
\text { Quality } \\
\text { Technological intensity }\end{array}$ & $\begin{array}{l}\text { Consumer Price Index } \\
\text { Product quality metrics } \\
\text { Research and development expenditures } \\
\text { Innovation metrics (patents and journal articles) }\end{array}$ \\
\hline
\end{tabular}

leather, wood, and media products. This allows for more detailed analysis of mediumand high-tech products. Domestic data tends to be in the North American Industry Classification System (NAICS). It is the standard used by Federal statistical agencies classifying business establishments in the U.S. NAICS was jointly developed by the U.S. Economic Classification Policy Committee, Statistics Canada, and Mexico's Instituto Nacional de Estadistica y Geografia and was adopted in 1997. Similar to ISIC, NAICS has several major categories each with subcategories. Historic data and some organizations continue to use the predecessor of NAICS, which is the Standard Industrial Classification system.

As seen in Table 2.3, there are a number of sources for data both domestically and internationally. Domestic sources include the U.S. Census Bureau, Bureau of Economic Analysis (BEA), National Science Foundation (NSF), and Bureau of Labor Statistics (BLS). International sources include the United Nations (UN), the Organization for Economic Co-operation and Development (OECD), World Economic Forum, and the International Institute for Management Development's (IMD) World Competitiveness Center. There are, of course, additional sources of data; however, those listed in Table 2.3 are many of the most prominent and cited sources of data on the domestic and international manufacturing industries.

Industry data being compared over time or between national currencies must be adjusted to a common comparable metric. Time series data is adjusted for inflation using a price 
index. The most suitable price index for tracking trends in the physical volume of production is the producer price index for the specific industry being discussed as it reflects the average change in the selling prices received by domestic producers for their output. It is typically used to measure real growth in output. ${ }^{37}$ However, industry specific producer price indices may not cover the entire span of time being discussed. In these cases, an approximation is used if the missing time span is relatively short. If the missing data spans a longer period of time, a closely related producer price index is selected. It is important to note that when multiple time series industry data are adjusted using different price indices the values no longer represent proportional changes in the value of production between industries. There are two primary factors that affect the aggregate value of manufactured goods: the physical volume of goods and the price (i.e., the product of price and physical volume equals aggregate value of goods). Data adjusted using the same price index accurately reflects proportional changes in the value of production because the original proportional magnitude is maintained between industries; however, it does not accurately reflect changes in the volume of production for each industry over time (e.g., declining cost of computer and electronic products). Thus, caution should be used when discussing the trends in manufacturing over time as the price index used to adjust manufacturing industry and subsector data can have a significant effect on the appearance of these trends. For this report, if a producer price index is not available then a consumer price index is used. In addition to adjusting for inflation, data in different currencies must be converted to a common currency. Some data sets used in this report, such as data from the United Nations Statistics Division (UNSD), are already converted to U.S. dollars using the International Monetary Fund's (IMF) market exchange rates. Other data sets, such as that from the OECD, are not converted. These data were converted using the OECD purchasing power parity (PPP) rates. This conversion eliminates the differences in price levels between countries; thus, in effect the resulting values reflect only differences in the volume of goods and services purchased. In some cases the time span of the data extends beyond OECD PPP data availability; therefore, the PPP rate from the Center for International Comparisons at the University of Pennsylvania was used.

\footnotetext{
${ }^{37}$ Bureau of Labor Statistics. "Producer Price Indexes: How Does the Producer Price Index Differ from the Consumer Price Index.” <http://www.bls.gov/ppi/ppicpippi.htm>
} 
Table 2.3: Sources of Data

\begin{tabular}{|c|c|c|}
\hline & Domestic Data and Information & International Data and Information \\
\hline \multirow{7}{*}{$\begin{array}{l}\text { Production } \\
\text { and Processes } \\
\text { of Production }\end{array}$} & Annual Survey of Manufactures (U.S. Census & \\
\hline & Bureau) & Gross Domestic Product (UN) \\
\hline & Economic Census (U.S. Census Bureau) & Manufacturing Value Added (OECD) \\
\hline & Gross Domestic Product (BEA) & Manufacturing Value Added (UN) \\
\hline & Manufacturers'Shipments, Inventories, and Orders & \\
\hline & (U.S. Census Bureau) & competitive industriai Pertormance index(UIV) \\
\hline & & Foreign Trade (U.S. Census Bureau) \\
\hline \multirow{6}{*}{$\begin{array}{l}\text { Research and } \\
\text { Development }\end{array}$} & Research and Development (National Science & \\
\hline & Foundation) & and Development Expenditures (OECD) \\
\hline & Producer Price Index (BLS) & Unit Labor Costs (OECD) \\
\hline & Manufacturing Employment (BLS) & Labor Compensation per Employee (OECD) \\
\hline & Productivity Index (BLS) & Labor Compensation per hour (OECD) \\
\hline & Pay and Benefits (BLS) & Hours Worked in Manufacturing (OECD) \\
\hline \multirow[t]{5}{*}{ Labor } & & Education Attainment (OECD) \\
\hline & & Employment (UN) \\
\hline & & Wages (UN) \\
\hline & & Population (U.S. Census Bureau International \\
\hline & & Database) \\
\hline \multirow{3}{*}{ Technology } & Research and Development (National Science & Patent Applications (OECD) \\
\hline & Foundation) & \\
\hline & & Percent of Patents that are Foreign Owned (OECD) \\
\hline \multirow{4}{*}{ All Categories } & & Global Competitiveness Report (World Economic \\
\hline & & Forum) \\
\hline & & Competitiveness Yearbook (IMD World \\
\hline & & Competitiveness Center) \\
\hline
\end{tabular}




\section{International Data: How the U.S. Compares to the Rest of the World}

This chapter discusses international data, which includes data on production in the U.S. and abroad. It lays out the principal data available on the manufacturing industry and then discusses the definitions used and trends in the data. There are many sources of information that provide data on individual nations. Unfortunately, identifying, adjusting, and accumulating this data would require a considerable amount of time and resources. Therefore, this report relies on sources that provide data on multiple nations to make international comparisons. These sources include the United Nations, Organization for Economic Cooperation and Development, World Bank, and a selection of international comparative indices.

As previously discussed, a successful industry might be considered one that has a suitable magnitude of production that results in competitive net benefits for its stakeholders. It is on this basis that data was selected to be incorporated into this chapter. Data was selected to compare net benefits of U.S. stakeholders to those abroad. This includes the total value added, net income, compensation, and employment among other things. Without this comparison, it is difficult to find meaning in many of the trends in U.S. manufacturing. For instance, it is difficult to argue that one rate of growth is sound and another rate is unsound without some comparison to the international community. In some instances rankings or percentiles are used to compare U.S. stakeholders to those abroad. Data related to research and development expenditures are also presented as these items reflect advancements in the industry.

It is important to note that although the U.S. proportion of research and production activities has declined, it is necessary to examine the nation's nominal and real performance relative to its population and resources to gain an understanding of what is happening. It should be expected that as emerging economies make progress in becoming developed countries that U.S. and other developed nation's proportion of production and research will decline due to the growth of total global production and research activities. ${ }^{38}$ That is, it is not to be expected that the U.S. will keep up with the aggregate growth of global research and production as much of these increases are the result of utilizing previously idle or under-utilized resources in emerging economies. A decline in the proportion of U.S. activities, therefore, is not unexpected and is not necessarily a decline in the performance of the domestic industry. A greater concern is its nominal and real performance relative to its population and/or resources. It is in this context that this report will compare U.S. manufacturing activity to that of other nations.

\footnotetext{
${ }^{38}$ Mandel, Benjamin R. "Why is the U.S. Share of World Merchandise Exports Shrinking." Federal Reserve Bank of New York: Current Issues. Vol. 18, No. 1. 2012. <http://www.newyorkfed.org/research/current_issues/ci18-1.pdf>
} 


\subsection{United Nations}

The United Nations (UN) is an international organization founded by 51 nations in 1945; the organization now has 193 member states. In addition to its commitment to maintaining peace and security, the UN compiles and disseminates statistical information on the global economy. It provides these statistics through the United Nations Statistics Division and the United Nations Industrial Development Organization. Data from these two entities are characterized below.

United Nations Statistics Division (UNSD) National Accounts Main Aggregates Database: The UNSD disseminates global statistics, develops standards for statistical activities, and provides assistance to nations developing statistical data. Their National Accounts Main Aggregates Database provides annual collections of official national accounts data. This information is collected via the United Nations National Accounts Questionnaire. For some countries a full set of official data is not reported. For these instances estimation procedures are employed to estimate the data. These data were converted from national currencies into U.S. Dollars by applying market exchange rates as reported by the International Monetary Fund (IMF). ${ }^{39}$

According to the UNSD data, as of 2008, the U.S. produced the largest volume of manufactured goods compared to all nations as seen in Figure 3.1. This figure contains manufacturing value added for the ten largest manufacturing nations and illustrates the magnitude and importance of the U.S. manufacturing industry to the global economy as well as the domestic economy. China produced about $2 \%$ less than the U.S. in 2008, but is expected to continue to grow rapidly. As seen in the pie charts in Figure 3.1, the U.S. produced $28 \%$ of the worlds manufactured goods in 1985 and declined to $18 \%$ in 2008 . Although significant, this decline may not be a point of concern. It is important to note that in order for underdeveloped countries to become developed countries, their production and income will need to approach that of the developed world. This, inevitably, results in a decline in the proportion or market share that each developed country represents. Thus, a decline in the U.S. share of global manufacturing is not by itself a point of concern. A decline may simply be the result of progress in emerging economies. Concern about such a decline often stems from the misleading analogy of the U.S. being compared to a company losing market share. When companies expand their market share it is often at the cost of another company. When an emerging economy increases production, however, it creates more demand for goods and services which increases the total market size. Thus, the increase in market share from increased production in one country may or may not be at the cost of another country.

Between 1985 and 2008, the U.S. manufacturing industry grew at a compound annual growth rate of approximately $1.1 \%$, according to UN data; consequently, it is growing slower than the whole of the U.S. economy, which grew at a $2.3 \%$ rate. Manufacturing in Canada, Japan, Germany, and the U.K grew faster at rates of $2.7 \%, 1.9 \%, 3.6 \%$ and

\footnotetext{
${ }^{39}$ United Nations Statistics Division. "National Accounts Main Aggregates Database." <http://unstats.un.org/unsd/snaama/Introduction.asp>
} 


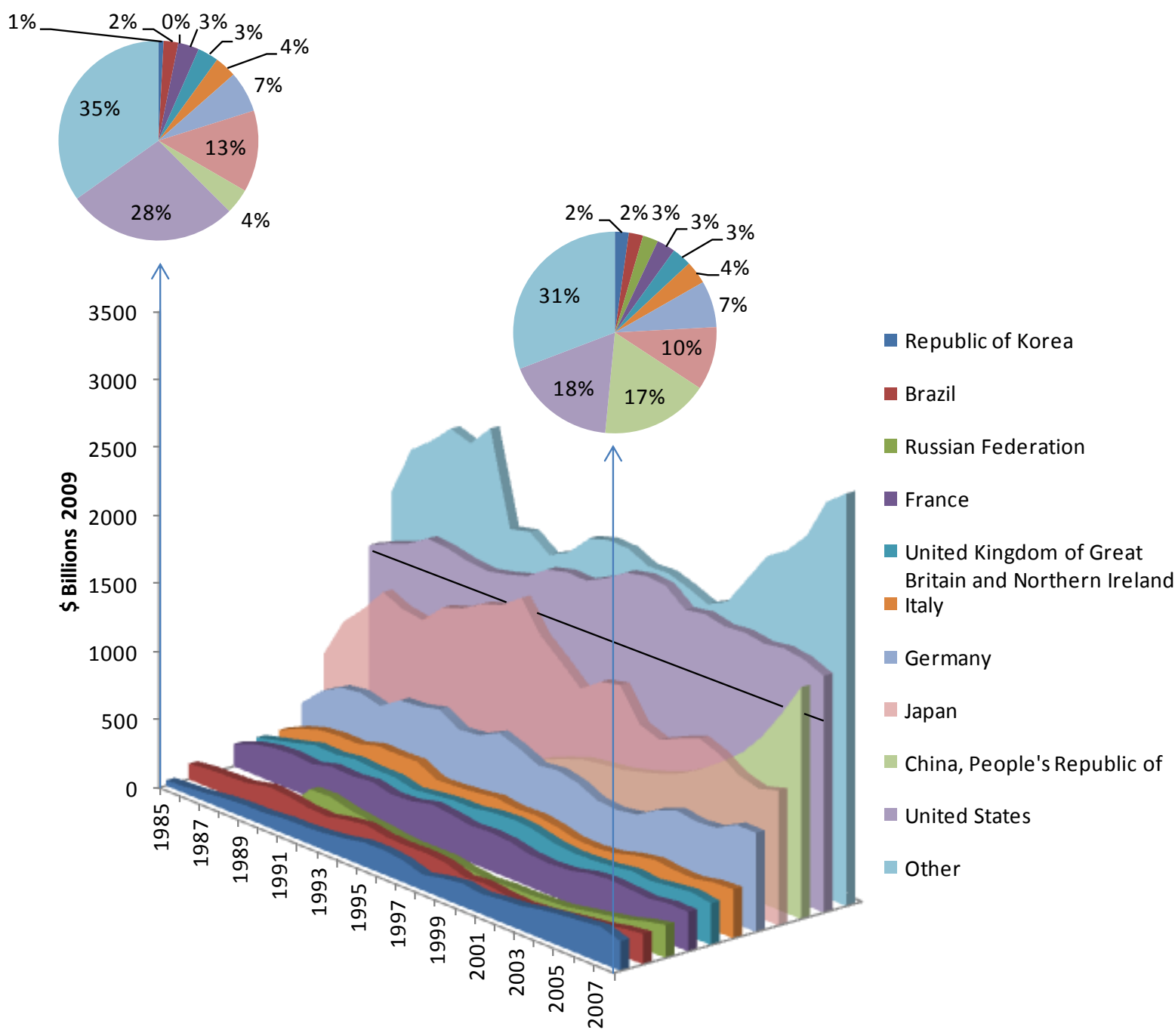

Figure 3.1: UNSD Manufacturing GDP by Nation (\$billions 2009)

Note: Converted to U.S. dollars using market exchange rates as reported by the International Monetary Fund (IMF) and adjusted to 2009 dollars using the BLS producer price index for manufacturing. UNSD data begins in 1970; however, the producer price index begins in 1985.

Note: The pie charts represent the percent of global manufacturing GDP that each nation represents for the year indicated.

$2.8 \%$ respectively. India and China grew much faster at rates of $5.1 \%$ and $9.8 \%$; emerging economies, such as these, can employ idle or underutilized resources and adopt technologies that are already proven in other nations to achieve high growth rates. Developed countries are already utilizing resources and are employing advanced technologies; thus, comparing U.S. growth to growth in China or India has limited meaning.

U.S. manufacturing growth from 1985 to 2008 is among the slowest with 151 out of 180 countries having a larger compound annual growth rate, putting it below the $20^{\text {th }}$ percentile (see Figure 3.2). It is important to note, however, that the U.S. was in the midst of a recession in 2008; therefore, it is useful to examine growth to the peak of U.S. 


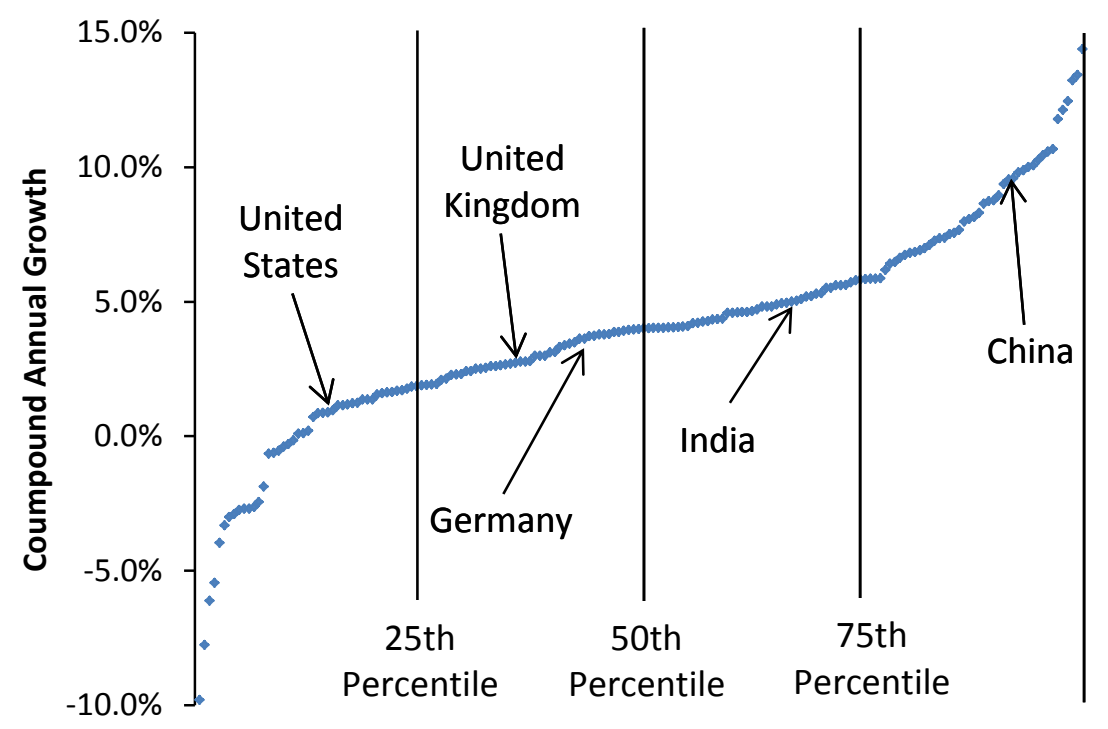

Figure 3.2: UNSD Manufacturing Value Added for 180 Countries, Compound Annual Growth Rate (1985-2008)

manufacturing. Accordingly, the industry grew $45 \%$ between 1985 to the peak of U.S. manufacturing in 1999. At least 156 countries had larger growth from 1985 to their manufacturing peak (growth from 1985 to the highest level of manufacturing for each country); this puts the U.S. below the $15^{\text {th }}$ percentile of 182 nations.

While manufacturing value added is larger in the U.S. than in any other country, U.S. manufacturing per capita has lagged slightly behind some industrialized nations, such as Germany and Japan. Out of 199 countries, at least 20 other nations had a higher manufacturing value added per capita than the U.S. in 2008, according to UNSD data. This ranking is down from being $2^{\text {nd }}$ in 1985. Between 1985 and 1995, the rank had slipped to $16^{\text {th }}$; however, it slowly climbed to $7^{\text {th }}$ between 1995 and 2000 . From there it slowly declined to $21^{\text {st }}$ in 2008 . As illustrated in Figure 3.3, U.S. per capita

manufacturing value added has fluctuated slightly between 1985 and 2008; however, the level in 2008 is only $1.5 \%$ higher than it was in 1985. Many countries had much higher increases; such as Germany and the United Kingdom, which increased $114.9 \%$ and $72.1 \%$, respectively. Out of 172 countries, the U.S. ranks as the $130^{\text {th }}$ largest increase, putting it below the $25^{\text {th }}$ percentile.

Manufacturing as a percent of total Gross Domestic Product (GDP) has declined in the U.S. as it has declined in many industrialized nations across the globe. In 1970, manufacturing was approximately $24.3 \%$ of U.S. GDP. By 2008, it represented approximately $13.0 \%$ as illustrated in Figure 3.4, which contains the same top ten manufacturing nations shown in Figure 3.1. During this same period, total manufacturing GDP for all countries for which data is available went from $26.7 \%$ to $17.1 \%$ of total GDP. This percentage declined for 111 out of 179 countries $(62.0 \%)$. In 1970, approximately $87.0 \%$ of 185 countries listed in the UNSD data had a lower manufacturing to GDP ratio than the U.S. In 2008, approximately $59.8 \%$ of 209 had a lower ratio. 


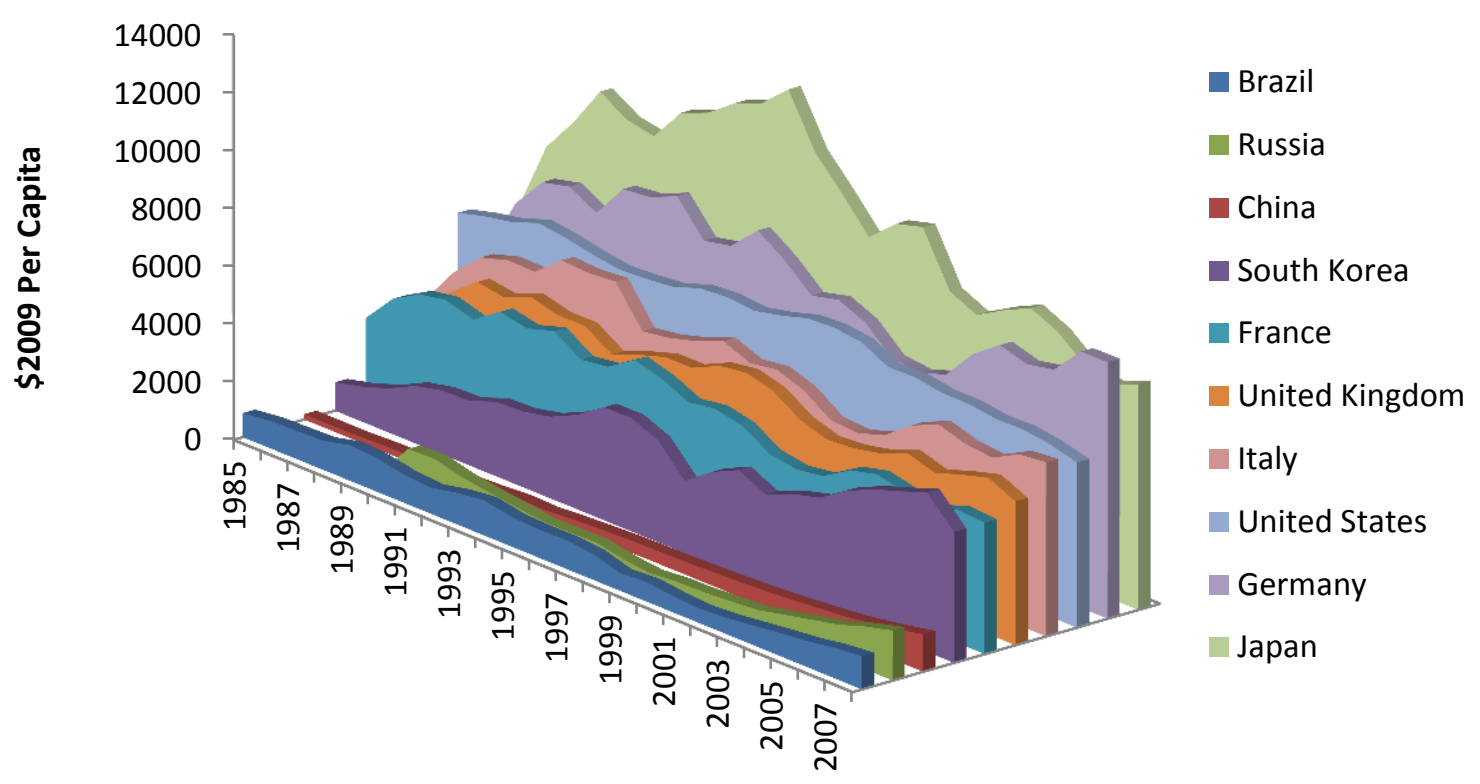

Figure 3.3: UNSD Manufacturing GDP per Capita

Note: population data is based on U.S. Census Bureau estimates of international population

United Nations Industrial Development Organization's (UNIDO) Statistical Country Briefs: The Statistical Country Briefs include national account data and industrial statistics compiled from various databases maintained by UNIDO. Industrial data on manufacturing are defined at the two (sometimes three) digit level of the International Standard Industrial Classification, Revision 3 (ISIC Rev. 3) system. National data has been converted to current U.S. dollars using the average period exchange rate in the IMF International Financial Statistics. ${ }^{40}$

Manufacturing employees exchange their time for income or wages. U.S. wages in the manufacturing industry are not the highest; however, they are not the lowest either. Among the nations shown in Table 3.1, the U.S. had the second highest level of wages slightly behind Germany, in 2006. This is the case for many of the subsectors shown in the table. Among those subsectors shown, the U.S. has the highest wages for other chemical product manufacturing, insulated wire and cable manufacturing, television and radio transmitter manufacturing, and transport equipment manufacturing. It is important to note that China's wages are among the lowest.

U.S. manufacturing industry stakeholders rely not only on the size of the industry, but the technology level of the products being produced. UNIDO data provides an opportunity to compare various aspects of U.S. manufacturing to other nations. Unfortunately, access to UNIDO data for all nations is somewhat limited; therefore, a selection of countries is used in Table 3.2 for comparison. These countries represent major U.S. trading partners,

${ }^{40}$ UNIDO. "Statistical Country Briefs." < http://www.unido.org/index.php?id=1000313> 


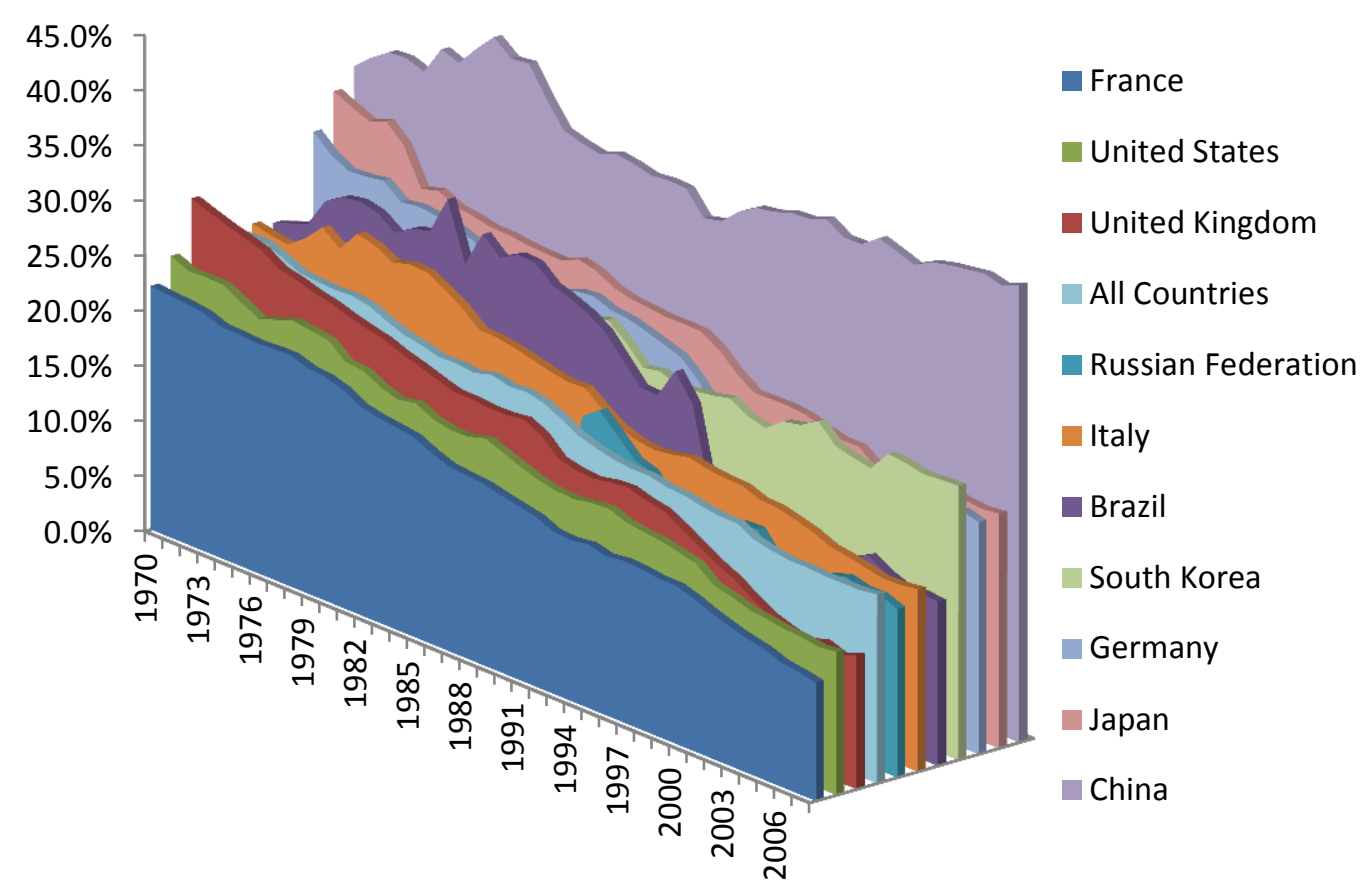

Figure 3.4: UNSD Manufacturing as a Percent of GDP (1970-2008)

countries that are often considered competitors with the U.S., and nations that are similar to the U.S. As seen in Table 3.2, data are unavailable for some industries for some countries. Among the countries shown in the table, the U.S. has the largest value added for ISIC codes 24, 25, 26, 28, 29, 30, 31, 32, 33, and 34-35 (note that data for ISIC 15-22, 23, and 36-37 are unavailable for the U.S.). In terms of the percent of total national value added, the U.S. is within 11 percentage points of all the countries listed for all the types of manufacturing listed with the largest gaps being in ISIC codes 24, 27, 29, and 34-35. The total value added, value added per capita, and value added per employee for all manufacturing exceeds that of all the other countries listed as is the case for ISIC codes 24, 30, and 33. China, however, has more employees involved with all types of manufacturing listed in the table while having a lower value added. This employment phenomenon may be a result of Chinese labor laws, the remnants of a command economy, or the types of products being produced. ${ }^{41}$ For the U.S., chemical manufacturing represents the largest percent of total value added for those industries shown with transportation being the second largest.

Per capita value added for all manufacturing is larger in the U.S. than the other countries listed in Table 3.2. The largest per capita sector of U.S. manufacturing is chemical manufacturing. Among the countries listed, the U.S. has the highest per capita manufacturing for ISIC codes 24, 26, 30, and 33. U.S. Employment in manufacturing exceeds that of Germany, India, Japan, Mexico, and the United Kingdom; however,

\footnotetext{
${ }^{41}$ Shepherd, Robert J. “The People's Dynasty: Culture and Society in Modern China." Modern Scholar. Lecture Series. (2010).
} 
China has more than five times as many employees. China's large employment numbers result in very low value added per employee, which is approximately $10 \%$ of the corresponding value for total manufacturing in the U.S. Among those listed, the U.S. has the largest value added per employee for ISIC codes 24, 25, 30, 31, 33, and 34-35.

Table 3.1: Annual Wages by Select Manufacturing Subsectors, \$2006 (UNIDO Statistical Country Briefs)

\begin{tabular}{|c|c|c|c|c|c|c|c|c|c|c|}
\hline ISIC & & 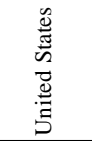 & $\underset{\frac{\pi}{\pi}}{\stackrel{.0}{\pi}}$ & 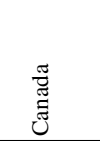 & $\stackrel{\widetilde{\Xi}}{\Xi}$ & $\underset{\Xi}{\stackrel{\Xi}{\Xi}}$ & 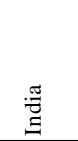 & Е & 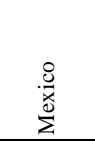 & 岁 \\
\hline 241 & Basic chemicals & 65446 & 23435 & 44103 & 2961 & 51943 & 3543 & 53073 & 14705 & 137197 \\
\hline 242 & Other chemical products & 59745 & 21470 & 35966 & 3373 & 57691 & 2223 & 45239 & 8845 & 55913 \\
\hline 243 & Man-made fibres & 44316 & - & 33839 & 2657 & 52736 & 3420 & 45650 & 5977 & 54290 \\
\hline 291 & General-purpose machinery & 47230 & - & 35203 & 3132 & 53395 & 2823 & 35743 & 4970 & 45267 \\
\hline 292 & Special-purpose machinery & 50827 & 18472 & 34600 & 3074 & 50892 & 2670 & 30779 & 5619 & 45282 \\
\hline 293 & Domestic appliances n.e.c. & 37923 & 17638 & 29843 & 3043 & 53630 & 1833 & 35212 & 4984 & 40303 \\
\hline 300 & Office, accounting, and computing machinery & 59817 & 11343 & 37729 & 4147 & 70390 & 3480 & 43515 & 5320 & 45685 \\
\hline 311 & Electric motors, generators, and transformers & 38990 & 21186 & 36320 & 3133 & 44936 & 3214 & 33759 & 6727 & 37010 \\
\hline 312 & Electricity distribution and control apparatus & 46087 & - & 30732 & 3435 & 62388 & 2430 & 32865 & 5081 & 38607 \\
\hline 313 & Insulated wire and cable & 44887 & 28126 & 42403 & 3118 & 43053 & 2054 & 43020 & 5838 & 37510 \\
\hline 314 & $\begin{array}{l}\text { Accumulators, primary cells, and primary } \\
\text { batteries }\end{array}$ & 42015 & 13072 & 29501 & 3090 & 51851 & 2320 & 48597 & 6686 & 39297 \\
\hline 315 & Electric lamps and lighting & 40876 & 18427 & 26292 & 2567 & 45296 & 1512 & 36820 & 3742 & 37524 \\
\hline 319 & Other electrical equipment & 48021 & - & 31073 & 3016 & 51849 & 2059 & 34669 & 5356 & 40521 \\
\hline 321 & $\begin{array}{l}\text { Electronic valves and tubes and other } \\
\text { components }\end{array}$ & 55543 & 26475 & 33892 & 3565 & 55980 & 3099 & 45244 & 5505 & 43609 \\
\hline 322 & $\begin{array}{l}\text { Television and radio transmitters and apparatus } \\
\text { for line telephony and line telegraphy }\end{array}$ & 67472 & 16401 & 38514 & 5642 & 61505 & 3073 & 48407 & 3551 & 59603 \\
\hline 323 & $\begin{array}{l}\text { Television and radio receivers, sound or video } \\
\text { recording or reproducing apparatus, and } \\
\text { associated goods }\end{array}$ & 46191 & - & 31765 & 3931 & 53013 & 2918 & 39034 & 6655 & 39793 \\
\hline 341 & Motor vehicles & 58581 & 16823 & 51412 & 4903 & 74085 & 5132 & 67092 & 11669 & 54979 \\
\hline 342 & Motor vehicle bodies, trailers, and semi-trailers & 36128 & 17122 & 26187 & 4461 & 38978 & 1391 & 57883 & 4729 & 35933 \\
\hline 343 & Motor vehicle parts, accessories, and engines & 50106 & 18596 & 34735 & 3013 & 56674 & 2318 & 43575 & 5463 & 43468 \\
\hline 351 & Building and repairing of ships and boats & 42304 & 25202 & 26690 & 4629 & 48154 & 2645 & 37076 & 4764 & 42845 \\
\hline 352 & $\begin{array}{l}\text { Railway and tramway locomotives and rolling } \\
\text { stock }\end{array}$ & 47708 & 22369 & 34042 & 3706 & 52651 & 1942 & 39345 & 7066 & 65370 \\
\hline 353 & Aircraft and spacecraft & 69177 & 59865 & 41670 & 4455 & 74180 & 7349 & 53046 & 6402 & 59247 \\
\hline 359 & Transport equipment & 48259 & - & 31042 & 2580 & 38689 & 2429 & 27510 & 5057 & 28202 \\
\hline $15-37$ & Total Manufacturing & 47204 & - & 30824 & 2899 & 47720 & 1781 & 30486 & 4847 & 41929 \\
\hline
\end{tabular}

Note: The green bars represent a visual comparison between countries. For example, the UK has the highest annual wages for ISIC 241; therefore, it has the longest bar for ISIC 241. 
Table 3.2: Detailed Manufacturing Value Added Industry Comparisons, 2006 (UNIDO Statistical Country Briefs)
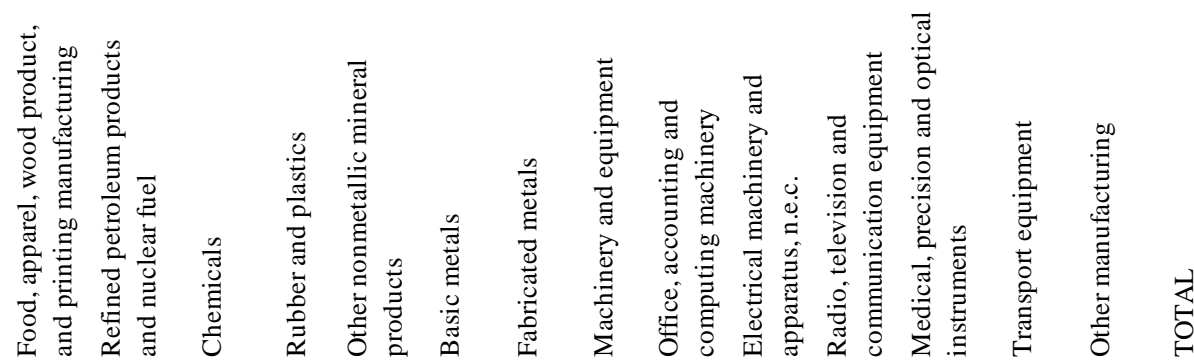

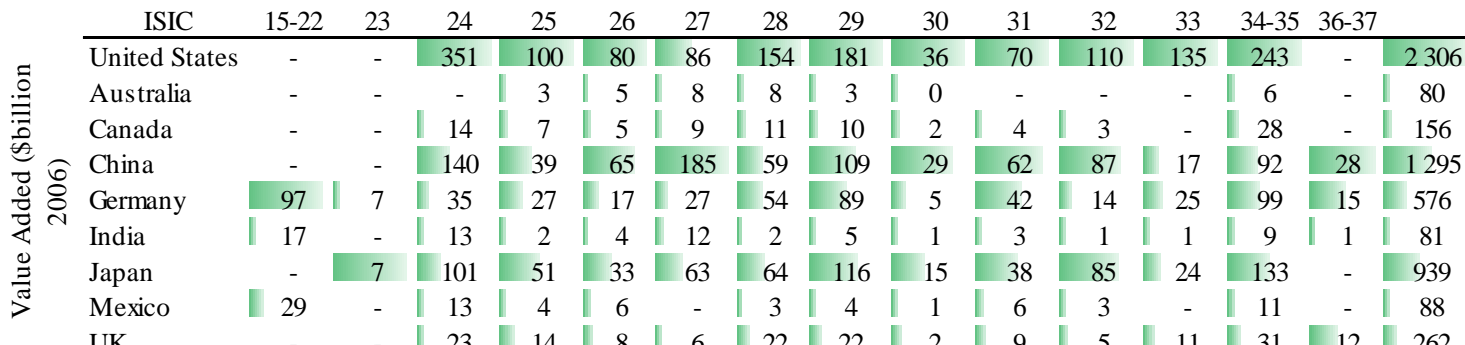

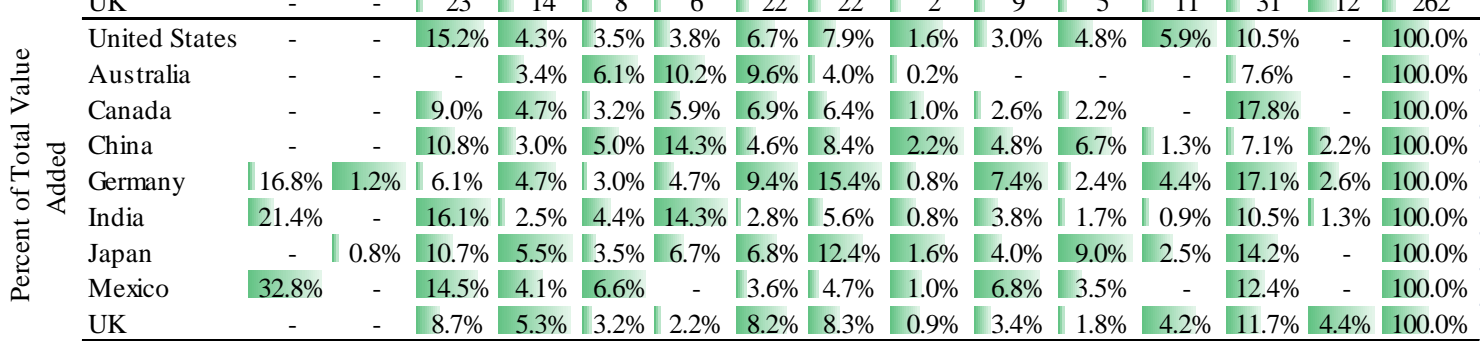

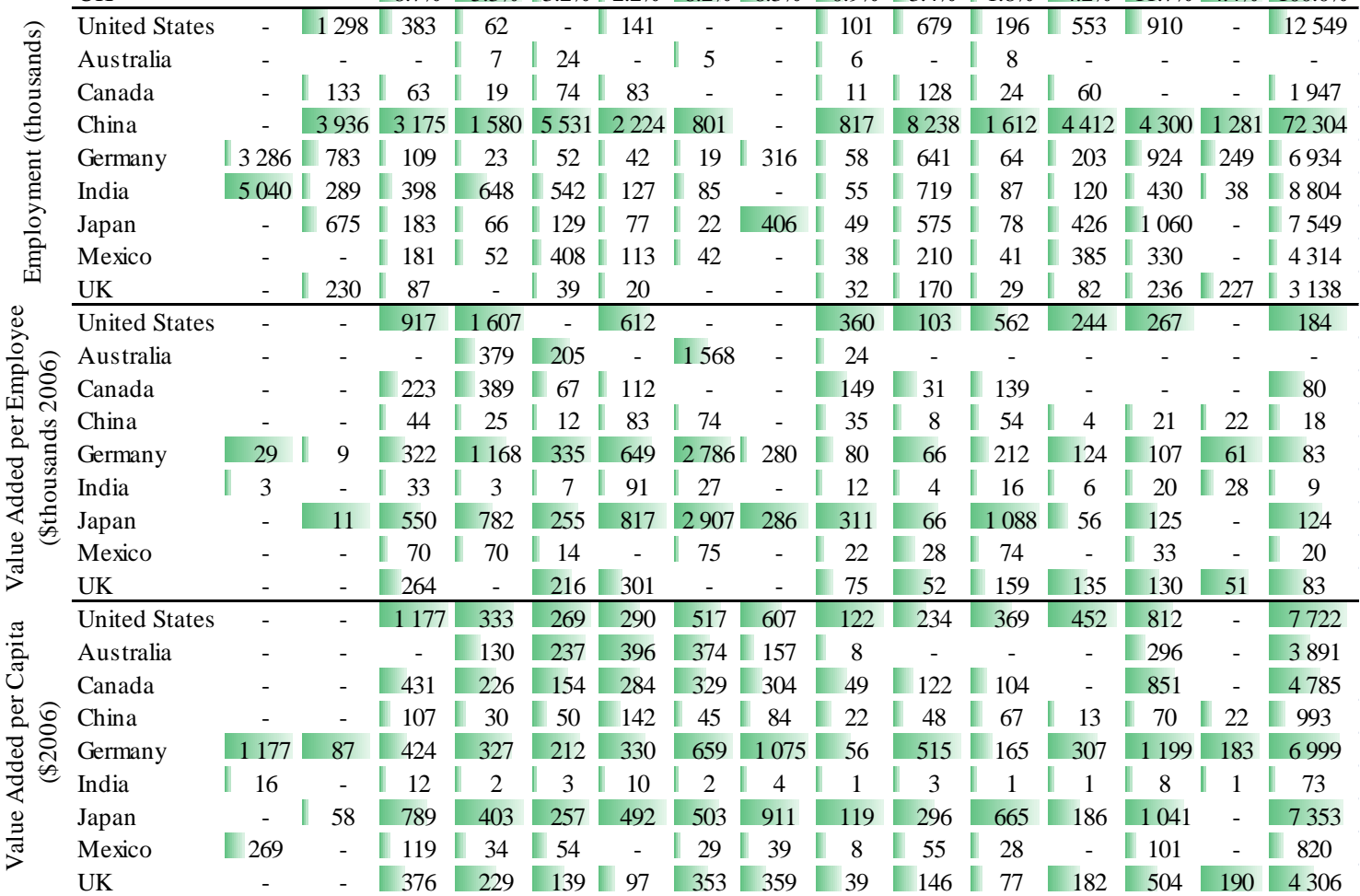

Note: The green bars represent a visual comparison between countries for each category (listed in the far left column) and subsector (listed in the top row) combination. For example, the U.S. has the largest value added for ISIC 15-22; therefore, it also has the longest green bar within the value added category for the ISIC 15-22 subsector. 


\subsection{Organization for Economic Cooperation and Development}

The Organization for Economic Cooperation and Development contains 34 member countries and was founded in 1961 in order to advance the economic and social wellbeing of people from across the globe. The OECD assembles and disseminates data characterizing its member countries along with non-member countries. A selection of OECD data is described below.

\subsubsection{Production}

Organization for Economic Co-operation and Development's (OECD) Structural Analysis (STAN) Data: The OECD StatExtracts provides various economic data, including value added by industry for OECD member countries. The STAN database provides detailed industrial data across a number of countries. It includes annual measures of output, labor input, investment, and international trade. Similar to data from the United Nations, some observations are estimates and are not official member country submissions and data is organized based on the International Standard Industrial Classification, Revision 3 (ISIC Rev. 3). ${ }^{42}$ National currencies are converted to dollars using the OECD purchasing power parity (PPP) rates for gross domestic product. This conversion eliminates the differences in price levels between countries; thus, in effect the resulting values reflect only differences in the volume of goods and services purchased.

Table 3.3 below presents STAN data for 9 countries; these are the same countries presented in Table 3.2. They represent major U.S. trading partners, countries that are often considered competitors with the U.S., and nations that are similar to the U.S. Unfortunately, STAN data is unavailable for three of the nations shown. Among the OECD countries for which data is shown in Table 3.3, the U.S. has the largest value added for all the manufacturing categories except basic metal and other manufacturing, which emphasizes the importance of U.S. manufacturing for the global economy. With the exception of ISIC 15-22, the percent of total value added in the U.S. for each manufacturing category is within 9 percentage points of the other nations. This shows some consistency which suggests that the sectors of U.S. manufacturing are not all that different from the other countries listed. That is, the proportion of manufacturing that each sector represents is similar to proportions in the other nations. Among the nations listed in Table 3.3, the U.S. has the largest value added per capita for refined petroleum products and nuclear fuel manufacturing along with office, accounting, and computing machinery manufacturing. Figure 3.5 provides a graph for three of the manufacturing subsectors: office, accounting, and computing machinery (ISIC 30); transportation equipment plus machinery and equipment (ISIC 29, 34-35); and chemicals (ISIC24). The U.S. has the largest value added for each sector shown for nearly the whole time period with the exception of 1991 where Japan exceeded the U.S. for office, accounting and computing machinery. In terms of value added per capita, the U.S. does not maintain the largest position.

${ }^{42}$ OECD. "StatExtracts." <http://stats.oecd.org/Index.aspx> 
Chemical manufacturing has been a large component of U.S. manufacturing as seen in Figure 3.6 and has grown significantly between 1985 and 2008. The largest component of total manufacturing is food, apparel, wood product, and printing manufacturing (ISIC 1522), which is not shown in the figure. Refined petroleum products and nuclear fuel increased $42 \%$ between 2000 and 2009. This increase is likely due in part to pressure to increase domestic oil production, technological advances in oil extraction using hydraulic fracturing, and increases in price.

Table 3.3: OECD Value Added, 2006

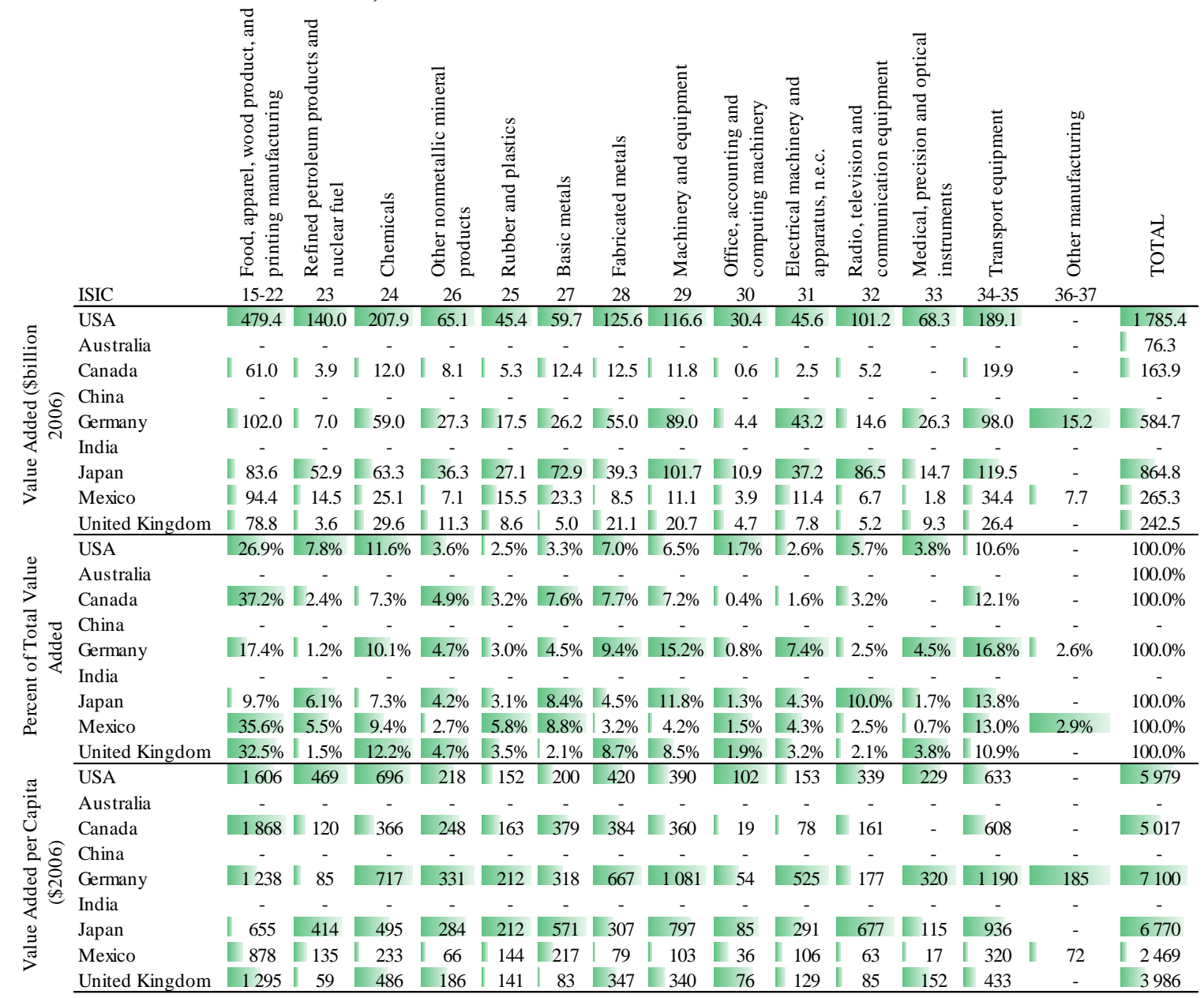

Note: The green bars represent a visual comparison between countries for each category (listed in the far left column) and subsector (listed in the top row) combination. For example, the U.S. has the largest value added for ISIC 15-22; therefore, it also has the longest green bar within the value added category for the ISIC $15-22$ subsector. 

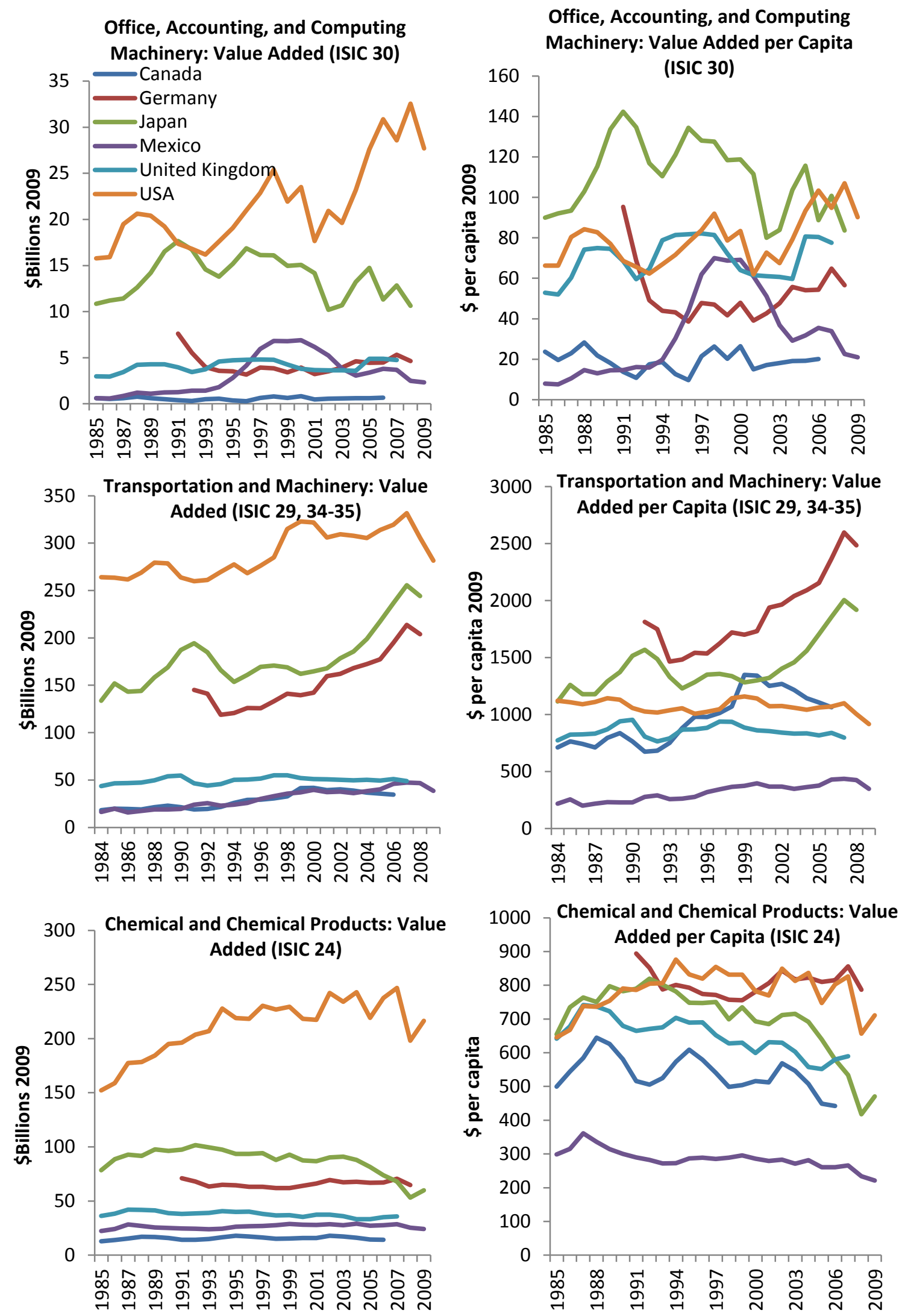

Figure 3.5: Selected Manufacturing Subsectors: Value Added and Value Added per Capita 
Among all OECD countries for which data is available in 2009, the U.S. ranks above the $70^{\text {th }}$ percentile in value added per capita for the following manufacturing sectors (see Table 3.4): food, apparel, wood product, and printing; refined petroleum products and nuclear fuel; chemicals; office, accounting, and computing machinery; radio, television and communication equipment; medical, precision, and optical instruments; transport equipment; and other manufacturing. The remaining sectors in manufacturing are below the $50^{\text {th }}$ percentile: other nonmetallic mineral products; rubber and plastics; basic metals; fabricated metals; machinery and equipment; and electrical machinery and apparatus. Between 2000 and 2009, some sectors had significant changes in their ranking while others remained relatively stable. It is important to note, in Table 3.4, that the number of countries for which data is available changes from year to year, which affects the percentile calculations.

Some U.S. sectors of manufacturing may rank high among OECD countries in terms of value added per capita; however, they may not rank high in terms of their return on investment in capital and labor. Earning a profit is a primary motivator for establishing a business. If a sector of U.S. manufacturing has a low return on investment, a company may decide to establish its production elsewhere. Table 3.5 uses the gross operating

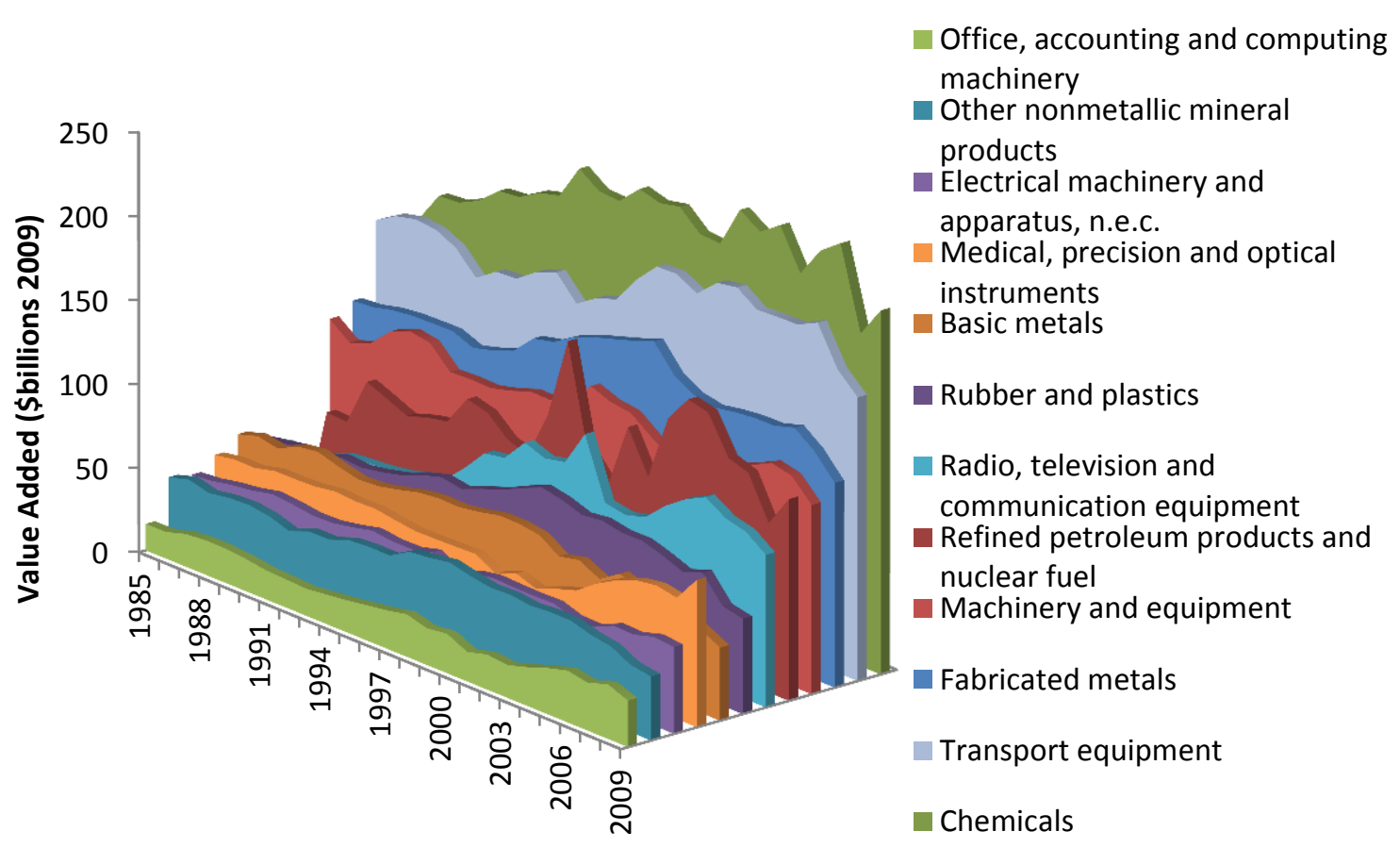

Figure 3.6: U.S. Manufacturing Value Added (excluding ISIC 15-22, 36, and 37) by Subsector (OECD Structural Analysis Database)

Note: Data for this figure was adjusted using the PPI for all manufacturing and the PPI for NAICS 324, $325,326,327,331,332,3332,3342$, and 336991 . 
surplus per expenditure dollar to proxy as a return on investment in a particular sector of manufacturing. Gross operating surplus is gross output less a subset of costs (i.e., intermediate expenditures, compensation, and taxes less subsidies) and does not take into account the depreciation of capital; therefore, it does not fully represent a return on investment. The OECD data does not contain U.S. values for depreciation. Expenditures is the sum of intermediate expenditures, compensation, and taxes less subsidies. As seen in the table, the U.S. is above the $70^{\text {th }}$ percentile for four sectors of manufacturing in 2009 and total manufacturing; however, data for 2009 is available from only a few countries. Unfortunately, data was not available for four of the sectors. Although there is some fluctuation in the rankings between 2001 and 2009 a number of the sectors never rise above the $70^{\text {th }}$ percentile: food, apparel, wood product, and printing; other nonmetallic mineral products; basic metals; and fabricated metals.

Productivity in the U.S. is considered to be quite high and this is reflected in Table 3.6, which shows the U.S. rank of the ratio of value added to the number of hours worked in manufacturing among OECD countries; unfortunately, a number of sectors do not have data available. In this table, total manufacturing in the U.S. is ranked above the $90^{\text {th }}$ percentile in 2009 and has consistently ranked above the $80^{\text {th }}$ percentile in other years. Additionally, four of the six sectors for which there is data are ranked above the $80^{\text {th }}$ percentile in 2009: food, apparel, wood product, and printing; refined petroleum products and nuclear fuel; chemicals; and machinery and equipment. U.S. wages consistently rank above the $70^{\text {th }}$ percentile and often above the $90^{\text {th }}$ percentile as seen in Table 3.7. In 2009, the highest rankings were in chemicals, other nonmetallic mineral products, fabricated metals, and machinery and equipment.

Table 3.4: U.S. Value Added per Capita by Year, Percentile (OECD Structural Analysis Database)

\begin{tabular}{|c|c|c|c|c|c|c|c|c|c|c|c|c|c|c|c|}
\hline & & 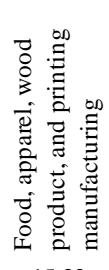 & 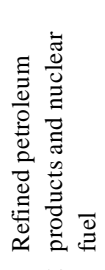 & $\begin{array}{l}\frac{\infty}{J} \\
. \stackrel{\Xi}{E} \\
\text { ల }\end{array}$ & 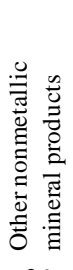 & 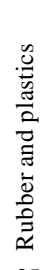 & 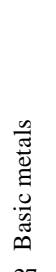 & 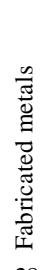 & 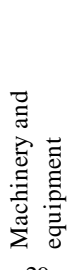 & 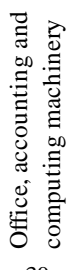 & 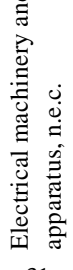 & 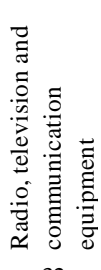 & 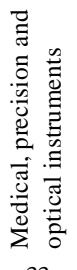 & 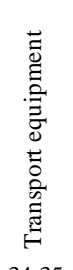 & 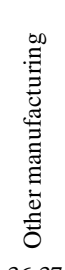 \\
\hline \multirow{9}{*}{ 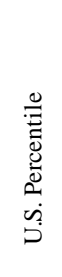 } & ISIC & $15-22$ & 23 & 24 & 26 & 25 & 27 & 28 & 29 & 30 & 31 & 32 & 33 & $34-35$ & $36-37$ \\
\hline & 2001 & 80.6 & 92.3 & 72.4 & 76.7 & 29.0 & 41.9 & 64.5 & 56.7 & 86.2 & 40.0 & 80.0 & 62.1 & 80.6 & 93.5 \\
\hline & 2002 & 80.6 & 88.5 & 75.9 & 70.0 & 29.0 & 45.2 & 54.8 & 50.0 & 86.2 & 46.7 & 80.0 & 62.1 & 80.6 & 93.5 \\
\hline & 2003 & 80.6 & 92.3 & 69.0 & 66.7 & 25.8 & 41.9 & 51.6 & 43.3 & 86.2 & 43.3 & 80.0 & 69.0 & 80.6 & 93.5 \\
\hline & 2004 & 80.6 & 92.3 & 69.0 & 66.7 & 22.6 & 45.2 & 61.3 & 50.0 & 90.0 & 36.7 & 76.7 & 72.4 & 77.4 & 93.5 \\
\hline & 2005 & 80.6 & 96.2 & 69.0 & 66.7 & 19.4 & 45.2 & 58.1 & 46.7 & 89.7 & 40.0 & 80.0 & 72.4 & 74.2 & 93.5 \\
\hline & 2006 & 70.0 & 96.0 & 67.9 & 55.2 & 13.3 & 43.3 & 56.7 & 44.8 & 92.9 & 37.9 & 75.9 & 71.4 & 73.3 & 93.3 \\
\hline & 2007 & 74.1 & 95.7 & 65.4 & 55.6 & 3.7 & 37.0 & 48.1 & 40.7 & 88.5 & 25.9 & 77.8 & 70.4 & 70.4 & 92.6 \\
\hline & 2008 & 72.0 & 90.5 & 58.3 & 40.0 & 0.0 & 33.3 & 33.3 & 36.0 & 95.5 & 27.3 & 81.8 & 73.9 & 56.0 & 84.0 \\
\hline \multirow{10}{*}{ 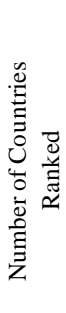 } & 2009 & 72.7 & 88.9 & 71.4 & 45.5 & 0.0 & 31.6 & 36.8 & 36.4 & 93.8 & 33.3 & 80.0 & 88.9 & 72.7 & 81.8 \\
\hline & 2001 & 31 & 26 & 29 & 30 & 31 & 31 & 31 & 30 & 29 & 30 & 30 & 29 & 31 & 31 \\
\hline & 2002 & 31 & 26 & 29 & 30 & 31 & 31 & 31 & 30 & 29 & 30 & 30 & 29 & 31 & 31 \\
\hline & 2003 & 31 & 26 & 29 & 30 & 31 & 31 & 31 & 30 & 29 & 30 & 30 & 29 & 31 & 31 \\
\hline & 2004 & 31 & 26 & 29 & 30 & 31 & 31 & 31 & 30 & 30 & 30 & 30 & 29 & 31 & 31 \\
\hline & 2005 & 31 & 26 & 29 & 30 & 31 & 31 & 31 & 30 & 29 & 30 & 30 & 29 & 31 & 31 \\
\hline & 2006 & 30 & 25 & 28 & 29 & 30 & 30 & 30 & 29 & 28 & 29 & 29 & 28 & 30 & 30 \\
\hline & 2007 & 27 & 23 & 26 & 27 & 27 & 27 & 27 & 27 & 26 & 27 & 27 & 27 & 27 & 27 \\
\hline & 2008 & 25 & 21 & 24 & 25 & 25 & 24 & 24 & 25 & 22 & 22 & 22 & 23 & 25 & 25 \\
\hline & 2009 & 22 & 18 & 21 & 22 & 22 & 19 & 19 & 22 & 16 & 15 & 15 & 18 & 22 & 22 \\
\hline
\end{tabular}


Table 3.5: U.S. Rank of Gross Operating Surplus per Dollar of Expenditure (OECD Structural Analysis Database)

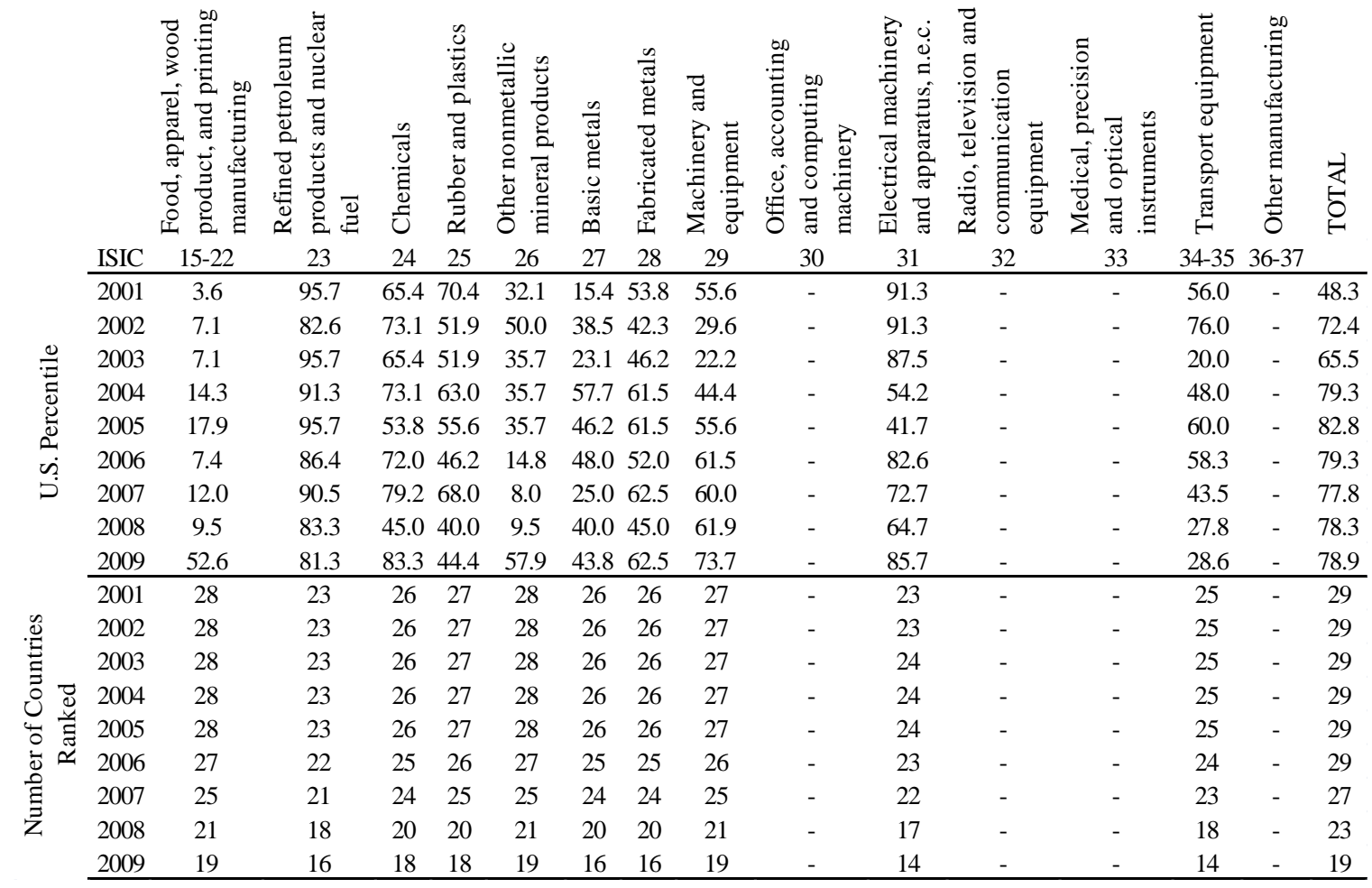

Table 3.6: U.S. Rank of the Ratio of Value Added to Hours of Work (OECD Structural Analysis Database)

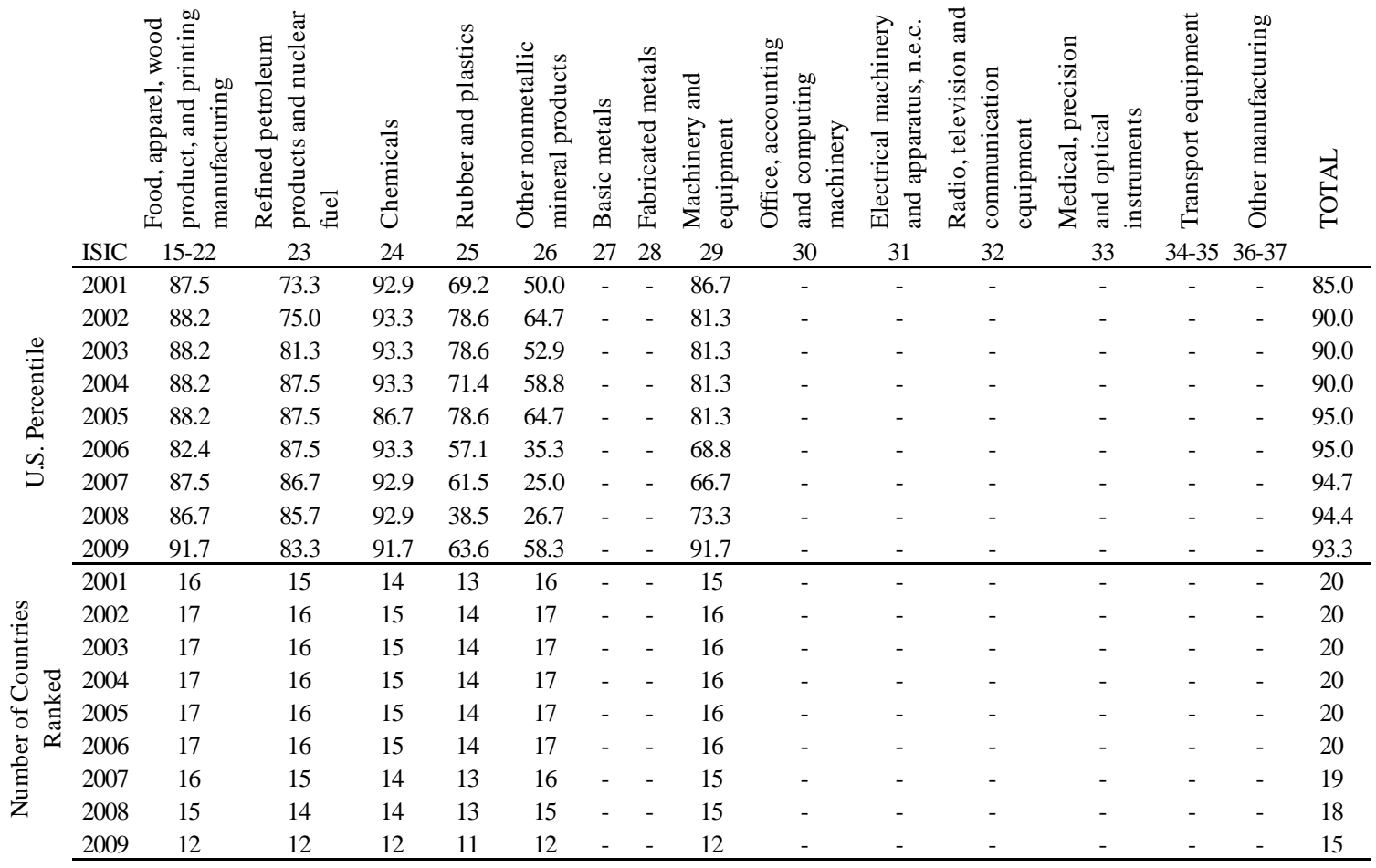


Table 3.7: Wages by Year, Percentile (OECD Structural Analysis Database)

\begin{tabular}{|c|c|c|c|c|c|c|c|c|c|c|c|c|c|c|c|c|}
\hline & & 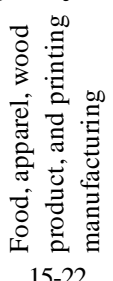 & 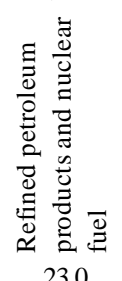 & 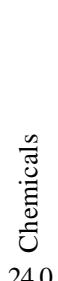 & 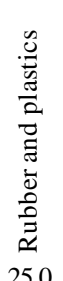 & 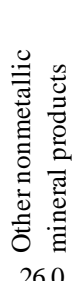 & 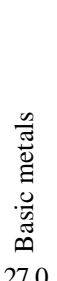 & 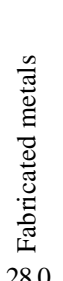 & 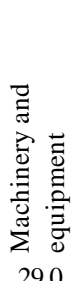 & 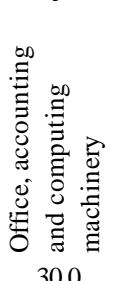 & 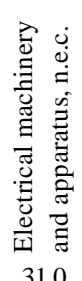 & 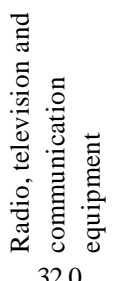 & 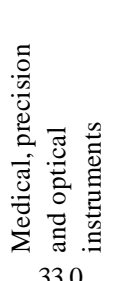 & 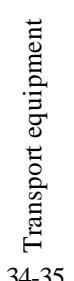 & 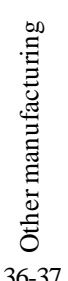 & 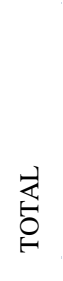 \\
\hline & Year & $15-22$ & 23.0 & 24.0 & 25.0 & 26.0 & 27.0 & 28.0 & 29.0 & 30.0 & 31.0 & 32.0 & 33.0 & 34-35 & 36-37 & \\
\hline \multirow{8}{*}{ 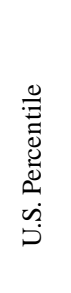 } & 2001 & 86.4 & 84.2 & 95.2 & 86.4 & 90.9 & 88.9 & 94.4 & 95.5 & 94.4 & 94.1 & 94.1 & 94.4 & 94.4 & - & 95.5 \\
\hline & 2002 & 86.4 & 84.2 & 95.2 & 86.4 & 95.5 & 89.5 & 94.7 & 95.5 & 94.4 & 94.1 & 94.1 & 94.4 & 94.4 & - & 95.5 \\
\hline & 2003 & 86.4 & 84.2 & 95.2 & 86.4 & 95.5 & 94.7 & 94.7 & 95.5 & 94.4 & 94.1 & 94.1 & 94.4 & 94.4 & - & 95.5 \\
\hline & 2004 & 86.4 & 84.2 & 95.2 & 86.4 & 95.5 & 89.5 & 94.7 & 95.5 & 88.9 & 88.2 & 94.1 & 94.4 & 94.4 & - & 95.5 \\
\hline & 2005 & 85.7 & 83.3 & 95.0 & 85.7 & 95.2 & 89.5 & 94.7 & 95.2 & 94.4 & 88.2 & 94.1 & 94.4 & 94.4 & - & 95.5 \\
\hline & 2006 & 90.5 & 88.9 & 95.0 & 81.0 & 90.5 & 89.5 & 89.5 & 95.2 & 94.4 & 88.2 & 94.1 & 94.4 & 94.4 & - & 95.5 \\
\hline & 2007 & 90.0 & 88.2 & 94.7 & 80.0 & 95.0 & 88.9 & 88.9 & 95.0 & 94.1 & 87.5 & 93.8 & 94.1 & 94.1 & - & 95.2 \\
\hline & 2008 & 86.7 & 84.6 & 93.3 & 86.7 & 87.5 & 84.6 & 92.3 & 93.3 & 91.7 & 81.8 & 90.9 & 91.7 & 91.7 & - & 94.1 \\
\hline \multirow{10}{*}{ 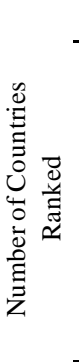 } & 2009 & 76.9 & 81.8 & 92.3 & 84.6 & 92.9 & 80.0 & 90.0 & 92.3 & 88.9 & 87.5 & 87.5 & 88.9 & 88.9 & - & 93.8 \\
\hline & 2001 & 22 & 19 & 21 & 22 & 22 & 18 & 18 & 22 & 18 & 17 & 17 & 18 & 18 & - & 22 \\
\hline & 2002 & 22 & 19 & 21 & 22 & 22 & 19 & 19 & 22 & 18 & 17 & 17 & 18 & 18 & - & 22 \\
\hline & 2003 & 22 & 19 & 21 & 22 & 22 & 19 & 19 & 22 & 18 & 17 & 17 & 18 & 18 & - & 22 \\
\hline & 2004 & 22 & 19 & 21 & 22 & 22 & 19 & 19 & 22 & 18 & 17 & 17 & 18 & 18 & - & 22 \\
\hline & 2005 & 21 & 18 & 20 & 21 & 21 & 19 & 19 & 21 & 18 & 17 & 17 & 18 & 18 & - & 22 \\
\hline & 2006 & 21 & 18 & 20 & 21 & 21 & 19 & 19 & 21 & 18 & 17 & 17 & 18 & 18 & - & 22 \\
\hline & 2007 & 20 & 17 & 19 & 20 & 20 & 18 & 18 & 20 & 17 & 16 & 16 & 17 & 17 & - & 21 \\
\hline & 2008 & 15 & 13 & 15 & 15 & 16 & 13 & 13 & 15 & 12 & 11 & 11 & 12 & 12 & - & 17 \\
\hline & 2009 & 13 & 11 & 13 & 13 & 14 & 10 & 10 & 13 & 9 & 8 & 8 & 9 & 9 & - & 16 \\
\hline
\end{tabular}

As previously discussed, manufacturing as a percent of GDP decreased for many countries and the aggregate of all countries (see Figure 3.4). During the same 1970 to 2008 period, manufacturing share of employment has decreased for many countries as seen in Figure 3.7, which shows all OECD countries for which data is available. Meanwhile production for many of these countries has remained relatively constant or increased during the 1984 to 2008 period (see Figure 3.3). Since employment is declining and output is remaining relatively constant or increasing, then, manufacturing labor productivity is increasing faster than the growth in demand for domestically produced manufactured products. Additionally, since manufacturing as a percent of GDP has decreased, then, the economy is growing faster than the demand for domestically manufactured products.

There is some discussion as to whether productivity increases directly explain declines in manufacturing employment in the U.S. According to Schweitzer and Zaman as well as Nordhaus, productivity increases do not explain the decreases in manufacturing employment. ${ }^{43,44}$ However, Ward claims that $80 \%$ of the job losses in the U.S. economy since 1990 are due to productivity increases $;{ }^{45}$ other authors also assert that increased productivity is the major reason for the decreased manufacturing employment

\footnotetext{
${ }^{43}$ Schweitzer, Mark and Saeed Zaman. "Are we Engineering Ourselves out of Manufacturing Jobs." Federal Reserve Bank of Cleveland. January 2006.

<http://www.clevelandfed.org/research/commentary/2006/0101.pdf>

${ }^{44}$ Nordhaus, William. "The Sources of the Productivity Rebound and the Manufacturing Employment Puzzle.” NBER Working Paper. May 2005. <http://www.nber.org/papers/w11354>

${ }^{45}$ Ward, William A. "Manufacturing Productivity and the Shifting US, China, and Global Job Scenes1990 to 2005." Clemson University Center for International Trade Working Paper 052507. August 2005. <http://ageconsearch.umn.edu/bitstream/112948/2/citpaper12.pdf>
} 


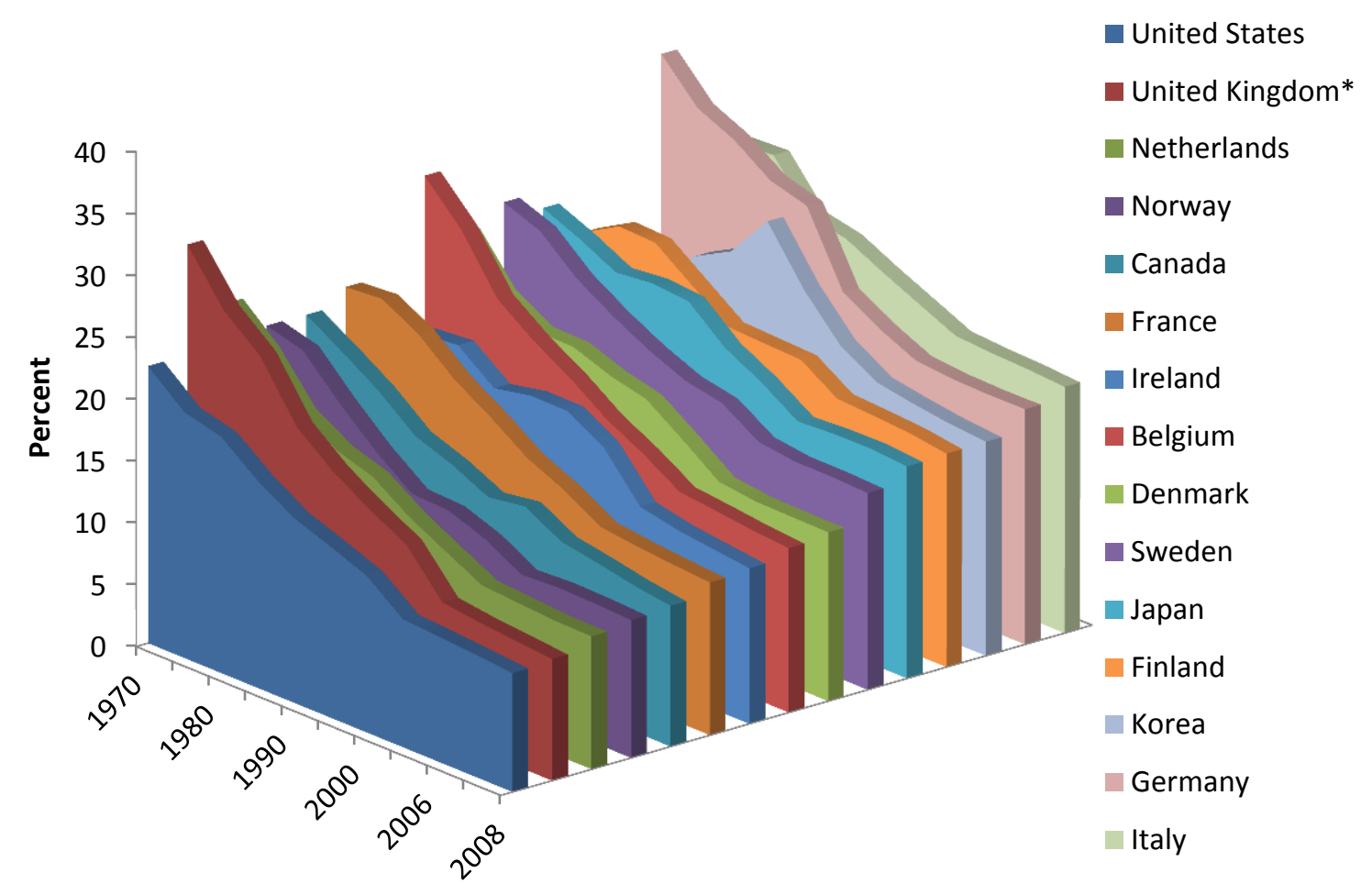

Figure 3.7: Manufacturing Share of Employment (OECD SDBS Business Demography Database) * The 1970 value for the United Kingdom was estimated using a rolling 10 year average change

numbers. ${ }^{46,47,48}$ These contrasting views need to be reconciled before any solid conclusions can be drawn concerning the decrease in manufacturing employment.

In addition to employment and production data, OECD also maintains data on the number of businesses started and ending during the year. As seen in Table 3.8, the 2005 U.S. employer enterprise birth rate (number of new enterprises divided by the number of existing enterprises) is less than the death rate; thus, more businesses were eliminated from manufacturing than were created. Seemingly, this trend has left the U.S. manufacturing industry with one of the lowest numbers of active employer enterprises per capita and also having a share of total employment lower than Germany, Italy, Japan, France, Canada, and the United Kingdom (not shown).

\footnotetext{
${ }^{46}$ Kelley, Charles, Mark Wang, Gordon Bitko, Michael Chase, Aaron Kofner, Julia Lowell, James Mulvenon, David Ortiz, and Kevin Pollpeter. March 2004. "High-Technology Manufacturing and U.S. Competitiveness." RAND Technical Report.

<http://www.rand.org/pubs/technical_reports/2004/RAND_TR136.pdf>

${ }^{47}$ Krugman, Paul R. and Robert Z. Lawrence. "Trade, Jobs, and Wages," Scientific American, April 1994: 22-27.

${ }^{48}$ Rowthorn, Robert and Ramana Ramaswamy. "Deindustrialization: Causes and Implications," April 1997. International Monetary Fund Working Paper WP/97/42.
} 
Table 3.8: Employer Enterprises in Manufacturing (OECD SDBS Business Demography Database)

\begin{tabular}{|c|c|c|c|c|c|c|}
\hline & $\begin{array}{c}\text { Employer } \\
\text { Enterprise } \\
\text { Birth Rate } \\
\text { (2005) } \\
\end{array}$ & $\begin{array}{c}\text { Employer } \\
\text { Enterprise } \\
\text { Death Rate } \\
\text { (2005) }\end{array}$ & $\begin{array}{c}\text { 2-Year } \\
\text { Survival } \\
\text { Rate (2006) }\end{array}$ & $\begin{array}{l}\text { Number of } \\
\text { Active } \\
\text { Employer } \\
\text { Enterprises } \\
(2005)\end{array}$ & $\begin{array}{c}\text { Number of } \\
\text { Active } \\
\text { Employer } \\
\text { Enterprises Per } \\
\text { Capita (2005) } \\
\text { (thousands) }\end{array}$ & $\begin{array}{l}\text { Employment } \\
\text { Shares in } \\
\text { Total Economy } \\
\text { (percent) } \\
\text { (2005) }\end{array}$ \\
\hline Australia & - & - & - & 56883 & 2.81 & 10.65 \\
\hline Austria & 4.74 & 5.62 & $79.85 * * *$ & | 22602 & 2.76 & 16.08 \\
\hline Belgium & $1.67 * *$ & $1.59 * *$ & - & | $20903^{* *}$ & $2.01 * *$ & 14.24 \\
\hline Brazil & 9 & 6.73 & - & 241370 & 1.30 & - \\
\hline Bulgaria & 8.36 & 4.49 & 61.90 & 21327 & 2.86 & - \\
\hline Canada & 7.32 & 7.24 & 73.88 & 58580 & 1.81 & 12.97 \\
\hline Czech Republic & 8.49 & - & - & 37850 & 3.70 & 27.46 \\
\hline Denmark & 6.45 & 9.28 & - & 11549 & 2.13 & 14.14 \\
\hline Estonia & 8.31 & 7.16 & 77.96 & 5057 & 3.79 & 22.97 \\
\hline Finland & 6.54 & 6.8 & 68.77 & 14424 & 2.76 & 18.11 \\
\hline Hungary & 7.55 & 8.97 & 61.93 & 39423 & 3.92 & 22.35 \\
\hline Israel & 6.3 & 4.74 & $68.53 * * *$ & 16447 & 2.44 & 13.15 \\
\hline Italy & 5.71 & 7.08 & 72.28 & 297531 & 5.04 & 20.45 \\
\hline Latvia & 7.77 & 3.8 & $77.65 * * *$ & 5815 & 2.54 & - \\
\hline Lithuania & 8.82 & - & - & 8054 & 2.24 & - \\
\hline Luxembourg & 6.62 & 4.5 & 85.29 & 755 & 1.61 & 11.53 \\
\hline Netherlands & 6.2 & 7.12 & 47.62 & 29898 & 1.83 & 11.25 \\
\hline New Zealand & - & - & 65.53 & - & - & 14.92 \\
\hline Norway & 4.39 & 2.96 & - & 11030 & 2.40 & 11.22 \\
\hline Portugal & 12.05 & 13.79 & $49.91 * * *$ & 99113 & 9.38 & 18.38 \\
\hline Romania & 12.42 & 8.2 & 75.03 & 51108 & 2.30 & - \\
\hline Slovak Republic & 9.93 & 7.13 & 74.96 & 23237 & 4.28 & 24.46 \\
\hline Slovenia & 5.68 & 5.54 & $80.54 * * *$ & 10487 & 5.21 & 26.05 \\
\hline Spain & 6.21 & 6.42 & 76.38 & 170923 & 3.91 & 16.12 \\
\hline Sweden & $5.61 * *$ & - & - & I26211 ** & $2.91 * *$ & 16.46 \\
\hline United States & 7.28 & 8.32 & 83.89 & 352181 & 1.19 & 10.35 \\
\hline
\end{tabular}

\subsubsection{Input-Output Data}

OECD STAN Input-Output Data: The STAN input-output data ${ }^{49}$ is collected and assembled in a different manner than the STAN data previously discussed; however, the input-output data has within it estimates of value added for various manufacturing subsectors. This data contains estimates for China, Australia, and India whereas previously discussed STAN data did not have them. Input-Output tables describe the sales and purchases of final and intermediate goods and services within an economy.

\footnotetext{
${ }^{49}$ The STAN input-output data and other input-output data presented in this report are based on a framework developed by Wassily Leontief. Leontief was awarded the Nobel Memorial Prize in Economic Sciences in 1973 for his pioneering work on input-output analysis.
} 
Data in the STAN tables are categorized by industry and are available for the mid-2000's, early 2000's, and the mid-1990's. The mid-2000's data are available for 39 countries representing over $90 \%$ of global GDP while the mid-1990's data is available for 36 countries representing over $70 \%$ of global GDP. ${ }^{50}$ These data have been converted to U.S. dollars using the OECD National Accounts Exchange rates.

The input-output data from the STAN database provide an estimate of value added for each two digit ISIC code in manufacturing. Table 3.9 provides the mid-2000's value as well as gross operating surplus per dollar of expenditure. Out of all 39 countries, the U.S. has the largest value added in the mid-2000's for all manufacturing subsectors except ISIC 27, 30, and 31 as seen in the rankings. According to the table, U.S. manufacturing value added is $13.1 \%$ of GDP while China is $34.2 \%$. In terms of value added per capita, the U.S. ranks $4^{\text {th }}$ in office, accounting, and computing machinery and $11^{\text {th }}$ for all manufacturing. The U.S. does not rank first for any subsector in terms of value added per capita. Gross operating surplus per dollar of expenditure, as seen in Table 3.9, proxies as a measure of the return on investment as gross operating surplus is similar to profit except it does not take into account the depreciation of capital. Expenditures include compensation of employees, taxes, and intermediate goods and services. The gross operating surplus per dollar of expenditure is 0.15 for the whole of U.S. manufacturing. Among the countries shown, India and Mexico have larger ratios at 0.19 and 0.27 . The largest ratio among the U.S. subsectors is 0.26 for ISIC 26, which includes the production of glass, ceramics, and other non-metallic mineral products. Table 3.10 breaks value added into three components: compensation, gross operating surplus, and taxes. The sum of these three items is equal to value added. Approximately $58.1 \%$ of U.S. manufacturing value added goes to the compensation of employees, $38.7 \%$ is gross operating surplus, and $3.1 \%$ is taxes. Only $31.2 \%$ of China's value added goes to the compensation of employees while $48.5 \%$ is gross operating surplus and $20.3 \%$ is taxes. Gross operating surplus being nearly 10 percentage points higher in China poses as a continued incentive for manufacturers to establish factories in China rather than in the U.S. In terms of gross operating surplus per dollar of expenditure, the U.S. ranks $14^{\text {th }}$ for total manufacturing and $9^{\text {th }}$ for office, accounting, and computing machinery (not shown).

\footnotetext{
${ }^{50}$ Yamano, Norihiki and Nadim Ahmad. "The OECD Input-Output Database: 2006 Edition. DSTI/DOC(2006)8. October 2006. STI Working Paper 2006/8. <http://www.oecd.org/dataoecd/46/54/37585924.pdf>
} 
Table 3.9: Value Added from the STAN Input-Output Data

\begin{tabular}{|c|c|c|c|c|c|c|c|c|c|c|c|c|c|c|c|c|}
\hline & ISIC & 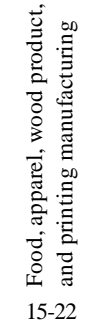 & 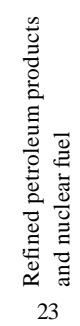 & $\begin{array}{l}\text { 岂 } \\
\text { हूँ } \\
\text { हूँ } \\
24 \\
24\end{array}$ & 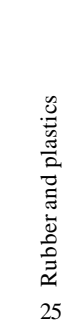 & 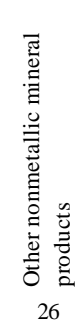 & 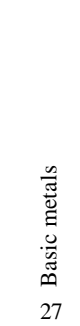 & 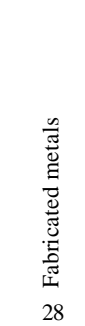 & 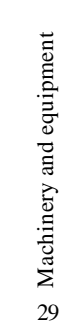 & 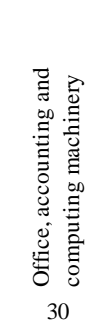 & 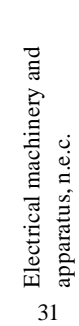 & 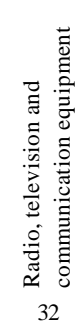 & 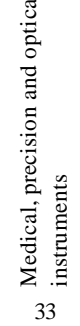 & 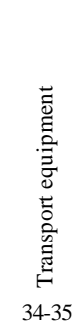 & 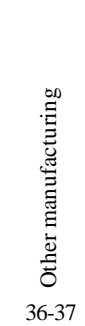 & 槖 \\
\hline \multirow{9}{*}{ 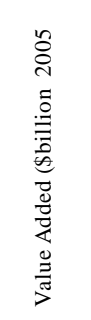 } & United Stat & 481 & 71 & 201 & 67 & 53 & 56 & 124 & 120 & 20 & 38 & 66 & 45 & 179 & 103 & 1624 \\
\hline & Australia & 28 & 2 & 5 & 3 & 3 & 7 & 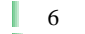 & 4 & 0 & 2 & 0 & 1 & 7 & 3 & 71 \\
\hline & Canada & || 61 & 4 & 12 & II 9 & 5 & 11 & 12 & I 11 & I & 3 & & 0 & 22 & 9 & 164 \\
\hline & China & 222 & 32 & 110 & 24 & 29 & 81 & 29 & 92 & 23 & 42 & 18 & 7 & 48 & 31 & 789 \\
\hline & Germany & 104 & I 6 & 59 & 27 & 17 & 26 & 51 & 86 & 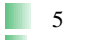 & 40 & 14 & 25 & 92 & 14 & 566 \\
\hline & In & 24 & 7 & | 14 & | 2 & | 4 & I 10 & 3 & ॥ 5 & 4 & | 3 & 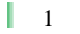 & 1 & 5 & 0 & 83 \\
\hline & $\mathrm{J}$ & 233 & 54 & 58 & 43 & 27 & 64 & 48 & 117 & 12 & 84 & 17 & 14 & 105 & 21 & 898 \\
\hline & $\mathrm{N}$ & I) 48 & 4 & || 12 & | 3 & I 8 & 7 & 4 & 3 & 7 & 4 & & & I 19 & 4 & 123 \\
\hline & UK & 88 & 5 & 30 & 13 & 10 & 6 & 23 & 22 & 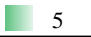 & 9 & & 10 & 29 & 12 & 269 \\
\hline \multirow{9}{*}{ 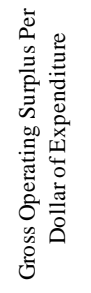 } & United St: & 0.15 & 0.14 & 0.24 & 0.15 & 0.26 & 0.13 & 0.16 & 0.13 & 0.19 & 0.22 & 0.16 & 0.05 & 0.06 & 0.19 & 0 \\
\hline & lia & 0.16 & 0.09 & 0.15 & 0.13 & $\| 0.15$ & 0.14 & 0.12 & 0.10 & - & 0.10 & & 0.10 & 0.10 & 0.11 & 0.14 \\
\hline & da & 0.17 & 0.05 & 0.15 & 0.15 & 0.24 & 0.14 & 14 & 0.16 & ॥ 0.01 & 0.10 & 0.09 & & 0.08 & 0.19 & 0.13 \\
\hline & China & 0.13 & 0.10 & 0.13 & 0.11 & 0.26 & 0.12 & 0.12 & 0.13 & 0.08 & 0.11 & 0.10 & 0.13 & 0.10 & 0.38 & 13 \\
\hline & Germany & 0.13 & 0.05 & 0.16 & 0.14 & 0.12 & 0.11 & 0.13 & 0.11 & 0.10 & 0.06 & 0.13 & 0.19 & 0.05 & 0.11 & 11 \\
\hline & $\mathrm{Ir}$ & 0.18 & 0.18 & 0.26 & 0.15 & 0.33 & 0.20 & 0.36 & 0.19 & 0.22 & 0.13 & 0.08 & 0.27 & 0.11 & - & 9 \\
\hline & Jap & 0.18 & 0.03 & 0.15 & 0.12 & 0.21 & 0.10 & 0.15 & 0.15 & 0.12 & 0.14 & 0.11 & 0.13 & 0.07 & ॥ 0.11 & 0.12 \\
\hline & $\mathrm{M}$ & 0.37 & 0.11 & 0.26 & 0.21 & 0.61 & 0.37 & 0.23 & 0.11 & 0.10 & 0.16 & & & 0.25 & 0.25 & 0.27 \\
\hline & $\underline{\mathrm{UK}}$ & 0.12 & 0.02 & 0.15 & 0.08 & 0.13 & 0.04 & 0.12 & 0.09 & 0.16 & 0.10 & 0.09 & 0.20 & 0.05 & 0.16 & 0.11 \\
\hline \multirow{9}{*}{ 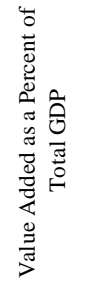 } & $\overline{\mathrm{u}}$ & $3.87 \%$ & $0.57 \%$ & $1.62 \%$ & $0.54 \%$ & $0.43 \%$ & $0.45 \%$ & $1.00 \%$ & $0.97 \%$ & 0.16 & $0.30 \%$ & $0.53 \%$ & $0.36 \%$ & $1.44 \%$ & $0.83 \%$ & 13 \\
\hline & lia & $4.67 \%$ & $0.26 \%$ & | $0.87 \%$ & $0.43 \%$ & $0.58 \%$ & 1.1 & $0.96 \%$ & $0.66 \%$ & | $0.00 \%$ & $0.41 \%$ & $0.00 \%$ & 0. & $\| 1.09 \%$ & $0.44 \%$ & | 11 \\
\hline & Inada & $5.76 \%$ & $0.36 \%$ & $\llbracket 1.14 \%$ & $0.82 \%$ & $0.47 \%$ & $1.00 \%$ & $1.15 \%$ & $1.07 \%$ & $0.05 \%$ & 【 $0.25 \%$ & $0.52 \%$ & $\%$ & $2.08 \%$ & $0.82 \%$ & $15.50 \%$ \\
\hline & China & $9.65 \%$ & $1.40 \%$ & $4.79 \%$ & $1.05 \%$ & $1.25 \%$ & $3.52 \%$ & $1.26 \%$ & $4.00 \%$ & $1.00 \%$ & $1.81 \%$ & $0.76 \%$ & $0.31 \%$ & $2.08 \%$ & $1.34 \%$ & $34.21 \%$ \\
\hline & ny & $4.15 \%$ & 0. & $2.34 \%$ & $1.07 \%$ & $0.67 \%$ & 1. & $2.02 \%$ & $3.41 \%$ & $0.19 \%$ & $1.57 \%$ & 0. & & $3.66 \%$ & $0.57 \%$ & 22 \\
\hline & In & $4.37 \%$ & 1. & $2.48 \%$ & 0.3 & $0.78 \%$ & 1. & 0. & $0.89 \%$ & $0.71 \%$ & $0.63 \%$ & 0. & $\%$ & 0. & 0 & 1. \\
\hline & $\mathrm{J}$ & $5.15 \%$ & $1.18 \%$ & $1.27 \%$ & 0.9 & $0.59 \%$ & 1. & 1. & $2.59 \%$ & 0.27 & $1.86 \%$ & 0. & 0 & $2.32 \%$ & 0. & 1 \\
\hline & Mexico & $7.16 \%$ & $0.57 \%$ & $1.86 \%$ & $0.52 \%$ & $1.19 \%$ & $1.08 \%$ & $0.56 \%$ & $0.42 \%$ & $1.04 \%$ & $0.58 \%$ & $0.00 \%$ & | $0.00 \%$ & $2.83 \%$ & $0.66 \%$ & 18 \\
\hline & UK & $4.35 \%$ & $0.22 \%$ & $1.50 \%$ & $0.66 \%$ & $0.47 \%$ & $0.29 \%$ & $1.16 \%$ & $1.10 \%$ & $0.26 \%$ & $0.42 \%$ & $0.28 \%$ & $0.51 \%$ & $1.45 \%$ & $0.59 \%$ & $13.26 \%$ \\
\hline \multirow{9}{*}{ 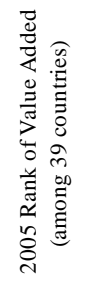 } & Un & 1 & 1 & 1 & 1 & 1 & 3 & 1 & 1 & T & 4 & 1 & 1 & 1 & 1 & \\
\hline & ralia & 14 & 21 & 19 & 16 & 14 & 13 & 13 & 19 & 34 & 15 & 36 & 19 & 14 & 17 & 17 \\
\hline & Canada & 8 & 17 & 15 & 9 & 12 & 7 & 10 & 10 & 17 & 14 & 11 & 36 & 8 & & 9 \\
\hline & $\mathrm{Ch}$ & 3 & 13 & 2 & 4 & II 2 & 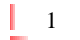 & 5 & 3 & 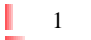 & I 2 & 4 & & & 12 & \\
\hline & $\mathrm{Ge}$ & 4 & & 3 & II 3 & 5 & 4 & 2 & 4 & 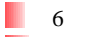 & II 3 & 6 & 2 & I 3 & I 5 & \\
\hline & India & 16 & 8 & 11 & 19 & 13 & 10 & 20 & 16 & I & 13 & 19 & 23 & 16 & 39 & 14 \\
\hline & Jap & ॥ 2 & I 2 & 4 & ॥ 2 & 3 & I 2 & II 3 & 2 & I & | 1 & 5 & 13 & | 2 & 3 & \\
\hline & & 11 & 18 & 14 & 12 & 9 & 14 & 19 & 24 & I & 12 & 36 & 36 & 9 & 12 & 12 \\
\hline & $\mathrm{UK}$ & 5 & 13 & 5 & 6 & 8 & 16 & 7 & 7 & D & 8 & 10 & & 6 & 6 & \\
\hline \multirow{9}{*}{ 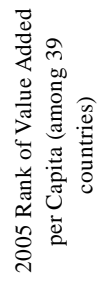 } & $\overline{\mathrm{U}}$ & 11 & 5 & 7 & 11 & 14 & 15 & 11 & 12 & I & 18 & 7 & 12 & 6 & 2 & \\
\hline & Australia & 15 & 18 & 22 & 21 & 15 & 9 & 19 & 22 & 34 & 19 & 36 & 20 & 14 & 18 & 21 \\
\hline & anada & 4 & 11 & 16 & I 5 & 22 & 10 & 15 & 17 & 16 & 23 & II 10 & 36 & I 5 & & 13 \\
\hline & China & 37 & 30 & 31 & 37 & 36 & 29 & 35 & 30 & 15 & 33 & 29 & 32 & 35 & 35 & 36 \\
\hline & German & 16 & 20 & 6 & I 3 & | 11 & 11 & 4 & 1 & E & 113 & I 9 & 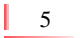 & 1 & 12 & \\
\hline & India & 39 & 35 & 38 & 39 & 38 & 37 & 38 & 38 & 31 & 39 & 35 & 35 & 39 & 39 & 39 \\
\hline & Japan & I 6 & 2 & 13 & 2 & 10 & 2 & 16 & 2 & I & 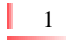 & 12 & 15 & 113 & 14 & 3 \\
\hline & & 29 & 29 & 27 & 32 & 29 & 27 & 33 & 36 & ! & 32 & 36 & 36 & 22 & 32 & 30 \\
\hline & UK & 14 & 19 & 1 9 & 12 & 19 & 22 & 13 & 14 & 1 & 16 & 17 & & 9 & 9 & 16 \\
\hline
\end{tabular}

Note: This data was adjusted using the PPI for all manufacturing for ISIC 15-22, 33, and 36-37; NAICS 324 for ISIC 23; NAICS 325 for ISIC 24; NAICS 326 for ISIC 25; NAICS 327 for ISIC 26; NAICS 331 for ISIC 27; NAICS 332 for ISIC 28; NAICS 3332 for ISIC 29; NAICS 3342 for ISIC 30; NAICS 3352 for ISIC 31; NAICS 3342 for ISIC 32; and NAICS 336991 for ISIC 34-35.

Note: The green and red bars represent a visual comparison between countries for each category (listed in the far left column) and subsector (listed in the top row) combination. Higher values have longer bars. Red bars signify instances where a lower value is preferred such as rankings (i.e., being $1^{\text {st }}$ is preferred over $\left.31^{\text {st }}\right)$. 
Table 3.10: Compensation, Gross Operating Surplus, and Taxes as a Percent of Value Added, mid2000's

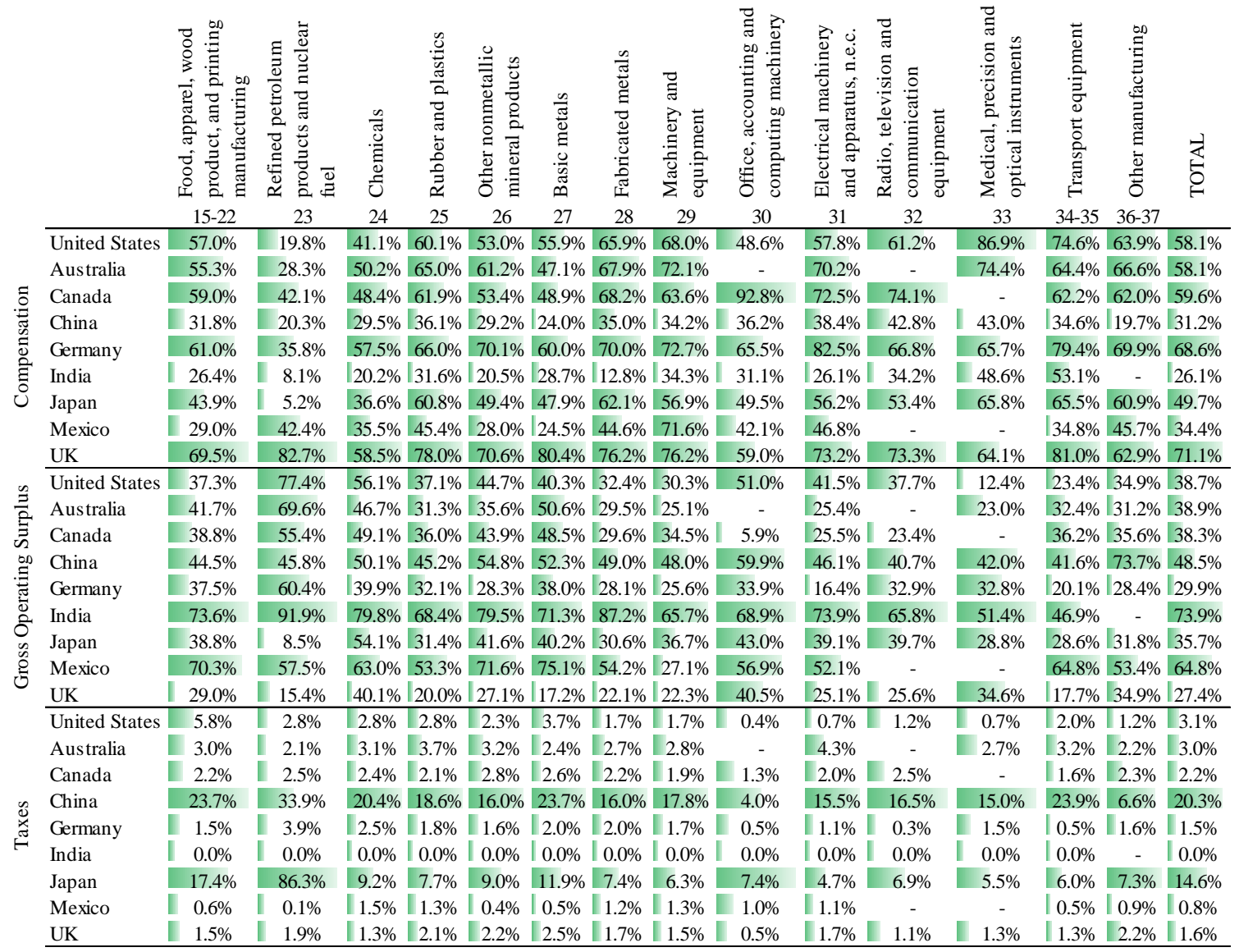

Note: The green bars represent a visual comparison between countries for each category (listed in the far left column) and subsector (listed in the top row) combination. Higher values have longer bars.

In using OECD data in input-output analysis, economies of scale are ignored; thus, it operates under constant returns to scale. The model also assumes that a sector uses inputs in fixed proportions. ${ }^{51}$ Table 3.11 uses this model to estimate the output of the manufacturing industry and the domestically produced goods and services used to produce that output. The U.S. output for electronics was $\$ 335$ billion with $\$ 115$ billion of non-manufactured goods and services used domestically in their production. The total impact from electronics is $\$ 450$ billion or $1.9 \%$ of total output. The total impact from machinery is $\$ 1511$ billion or $6.5 \%$ of total output. The whole of the U.S. manufacturing industry impacts $\$ 6446$ billion or $27.9 \%$ of total output. This percentage is lower than in other countries such as China, Germany, India, and Japan which have impacts of $62.1 \%$, $44.9 \%, 45.3 \%$, and $41.2 \%$ respectively. According to these data, the U.S.

manufacturing industry uses $18.3 \%$ of total U.S. research and development output (not shown).

\footnotetext{
${ }^{51}$ Miller, Ronald E. and Peter D. Blair. Input-Output Analysis: Foundations and Extensions. (New York: Cambridge University Press, 2009): 16
} 
Table 3.11: Input-Output Analysis using OECD STAN Data, mid-2000's

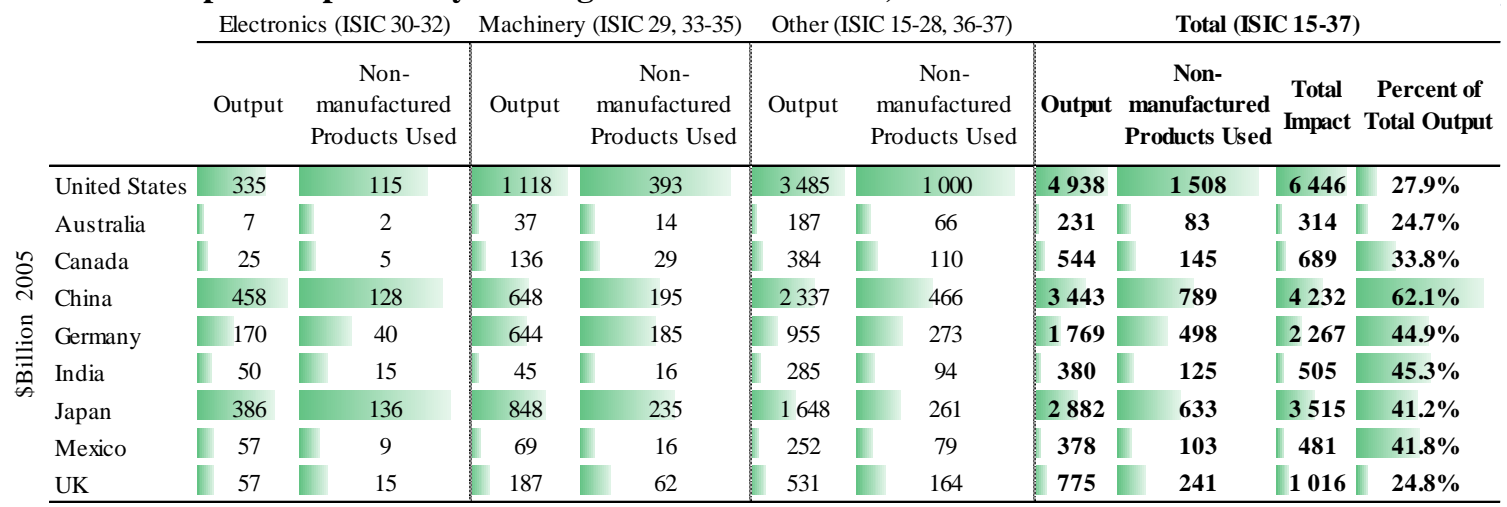

Note: The green bars represent a visual comparison between each country for each category (listed in the top row). Higher values have longer bars.

\subsubsection{Research and Development}

Research and Development Expenditures: In addition to data on production, the STAN database provides estimates on research and development expenditures by nation. Similar to production data, national currencies are converted to dollars using the OECD purchasing power parity (PPP) rates for gross domestic product. Research and development data is available for 1999 through 2006.

To maintain a strong manufacturing environment, the U.S. must have a healthy investment in the research and development of new products. Significant concern has been expressed in regards to U.S. research and development expenditures compared to those abroad. ${ }^{52}$ This concern is primarily in regards to its proportion of global research and development expenditures. ${ }^{53}$ There is also concern that the share of U.S. patents filed by inventors residing in the U.S. has decreased in recent years as have peer-reviewed publications. ${ }^{54}$ As previously mentioned, it is important to examine the nation's nominal and real performance relative to its resources. It should be expected that as emerging economies make progress in becoming developed countries that U.S. and other developed nation's proportion of production and research will decline due to the growth of total global production and research activities. That is, it is not to be expected that the U.S. will keep up with the aggregate growth of global research and production as much of these increases are the result of utilizing previously idle or under-utilized resources. A decline of the proportion of U.S. activities, therefore, is not unexpected. A greater concern is its nominal and real performance relative to its population and/or resources. It is in this context that this report will compare U.S. research and development to that of other nations.

\footnotetext{
52 Atkinson, Robert D. and David B. Audretsch. "Economic Doctrines and Policy Differences: Has the Washington Policy Debate Been Asking the Wrong Questions?" The Information Technology and Innovation Foundation. September 2008. < http://www.itif.org/files/EconomicDoctrine.pdf>

53 Tassey Gregory. "Rationales and Mechanisms for Revitalizing U.S. Manufacturing R\&D Strategies." Journal of Technology Transfer. 35 (2010). 283-333.

${ }^{54}$ National Science Board. "Research and Development: Essential Foundation for U.S. Competitiveness in a Global Economy.” 2008. <http://www.nsf.gov/statistics/nsb0803/nsb0803.pdf>
} 
Although data is available on research and development, there have been calls for improvements in statistics on research and development along with innovation. Data on this subject has been identified as insufficient and underutilized. ${ }^{55}$ It is also important to note that there are concerns in the linkage of moving innovation into domestic manufacturing. That is, there are occasions where U.S. research and development produces a new technology only for that technology to be utilized in manufacturing overseas. It has been identified that in at least some cases this transfer was not the result of lower production costs, but rather a result of other market factors. The production of Lithium-ion batteries is an example of this type of issue. ${ }^{56}$ Concern has been expressed in that as some manufacturing activities move abroad that supporting activities may follow.

According to the adjusted OECD STAN data in Table 3.12, the U.S. has the largest research and development expenditure for ISIC 15-22, 23, 24, 28, 29, 32, 33, 34-35, and for total manufacturing among those countries shown. In per capita terms, the U.S. has the largest research and development expenditures for ISIC 23, 24, 32, and 33. Germany spends nearly as much as the U.S. in per capita research and development for all manufacturing while Japan exceeds the U.S. expenditure by more than $30 \%$.

As seen in Table 3.13, among all OECD countries for which data are available the U.S. ranks above the 95th percentile for total manufacturing research and development expenditures for all years. From 2001 through 2007, it was above the 90th percentile for all subsectors of manufacturing. In terms of per capita research and development expenditures, 2007 U.S. values rank above the 70th percentile for ISIC codes 15-22, 23, 24, 29, 30, 32, 33, 34-35, 36-37, and total manufacturing (see Table 3.14).

Patents: OECD patent data includes the number of patents filed by the inventor's country of residence for 48 countries including China and India as well as a world estimate. The OECD patent database includes applications to the European Patent Office (EPO) and U.S. Patent and Trademark Office (USPTO) as well as those filed under the Patent Cooperation Treaty (PCT) and Triadic Patent Families. Patents reflect inventive performance and, therefore, are a key measure of innovation. There are, however, some drawbacks in using patents to measure innovation. Many patents have no industrial application. Also, many inventions are not patented either because they are not patentable or the inventor uses other means of intellectual property protection such as secrecy. Finally, patent laws change over time and vary between countries making it difficult to draw solid conclusions from data comparisons. ${ }^{57}$ In contrast to these shortcomings, research by de Rassenfosse and van Pottelsberghe has shown a high correlation between patent numbers and R\&D performance. ${ }^{58}$

\footnotetext{
${ }^{55}$ National Science Foundation. “Advancing Measures of Innovation.” June 2006.

<http://www.nsf.gov/statistics/nsf07306/>

${ }^{56}$ Brodd, Ralph J. "Factors Affecting U.S. Production Decisions: Why are There No Volume Lithium-Ion Battery Manufacturers in the United States.” ATP Working Paper 05-01. June 2005.

<http://www.atp.nist.gov/eao/wp05-01/wp05-01.pdf>

${ }^{57}$ OECD. OECD Patent Statistics Manual. OECD 2009.

<http://browse.oecdbookshop.org/oecd/pdfs/free/9209021e.pdf>

${ }^{58}$ De Rassenfosse, G. and B. van Pottelsberghe "A Policy Insight into the R\&D Patent Relationship." ULB Working Paper. 2008.
} 
According to OECD patent data, as seen in Table 3.15, between 1999 and 2007 the U.S. has ranked above the $90^{\text {th }}$ percentile in terms of total number of patents and above the $80^{\text {th }}$ percentile in terms of patents per capita. During that same period, U.S. patents represented between $30 \%$ and $41 \%$ of total patents worldwide. This data is consistent with a patent analysis conducted by Thomson Reuters, which suggested that approximately $40 \%$ of the top 100 global innovator companies are located in the United States. ${ }^{59}$ According to the OECD data, Japan is the only country that occasionally produced more patents than the U.S. while Luxembourg, Switzerland, and Japan produced more patents per capita in 2007.

Table 3.12: Research and Development Expenditures by Country, 2006 (OECD STAN Database)

\begin{tabular}{|c|c|c|c|c|c|c|c|c|c|c|c|c|c|c|c|c|}
\hline & & 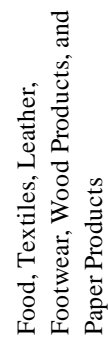 & 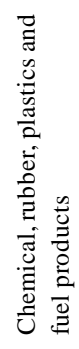 & 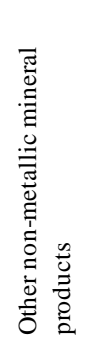 & 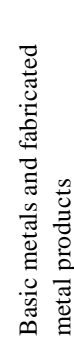 & 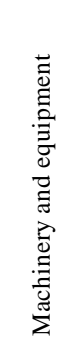 & 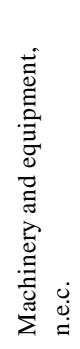 & 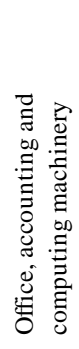 & 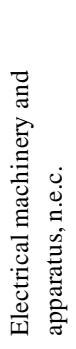 & 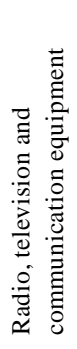 & 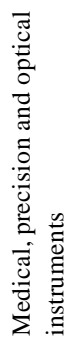 & 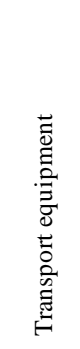 & 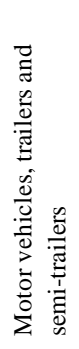 & 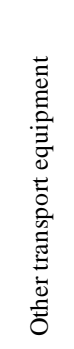 & 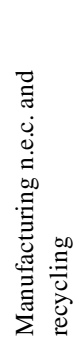 & 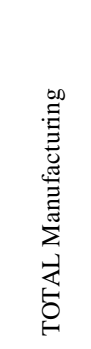 \\
\hline & ISIC & $15-22$ & 23 & 24 & 26 & 25 & 27 & 28 & 29 & 30 & 31 & 32 & 33 & $34-35$ & $36-37$ & \\
\hline \multirow{9}{*}{$\begin{array}{l}0 \\
8 \\
0 \\
\text { ते } \\
0 \\
0 \\
0 \\
0\end{array}$} & United States & 4.52 & 1.44 & 46.33 & 1.01 & 2.25 & 0.65 & 1.50 & 9.85 & 7.37 & 2.28 & 31.18 & 22.40 & 37.26 & - & 172.73 \\
\hline & Australia & 0.52 & 0.07 & 0.37 & 0.07 & 0.05 & 0.35 & 0.09 & 0.17 & 0.04 & 0.03 & 0.16 & 0.30 & 0.61 & 0.02 & 2.86 \\
\hline & Canada & 1.07 & 0.11 & 1.22 & 0.05 & 0.04 & 0.21 & 0.15 & 0.42 & 0.30 & 0.11 & 2.09 & 0.19 & 1.30 & - & 7.56 \\
\hline & China* & 1.33 & 0.42 & 2.42 & 0.47 & 0.38 & 1.32 & 0.30 & 1.92 & 0.58 & 1.48 & 3.26 & 0.43 & 1.73 & - & 16.16 \\
\hline & Germany & 0.78 & 0.08 & 8.51 & 0.32 & 0.86 & 0.48 & 0.59 & 5.13 & | 0.66 & 1.50 & 4.21 & 3.59 & 17.70 & 0.21 & 44.62 \\
\hline & India & - & - & - & - & - & - & - & - & - & - & - & - & - & - & - \\
\hline & Japan & 1.36 & 0.47 & 17.01 & 1.19 & 2.55 & 2.61 & 0.94 & 9.36 & 14.58 & 9.18 & 12.62 & 4.76 & 19.34 & - & 99.74 \\
\hline & Mexico & - & - & - & - & - & - & - & - & - & - & - & - & - & - & - \\
\hline & UK & - & - & - & - & - & - & - & - & - & - & - & - & - & - & - \\
\hline \multirow{9}{*}{ 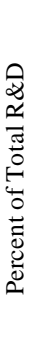 } & United States & $2.6 \%$ & $0.8 \%$ & $26.8 \%$ & $10.6 \%$ & $1.3 \%$ & $0.4 \%$ & $0.9 \%$ & $5.7 \%$ & $4.3 \%$ & $1.3 \%$ & $18.1 \%$ & $13.0 \%$ & $21.6 \%$ & - & $100.0 \%$ \\
\hline & Australia & $18.3 \%$ & $2.5 \%$ & $13.1 \%$ & $2.5 \%$ & $1.7 \%$ & $12.3 \%$ & $3.2 \%$ & $6.0 \%$ & | $1.3 \%$ & $1.1 \%$ & $5.5 \%$ & $10.5 \%$ & $21.4 \%$ & $0.7 \%$ & $100.0 \%$ \\
\hline & Canada & $14.2 \%$ & $1.5 \%$ & $16.2 \%$ & $0.6 \%$ & $0.6 \%$ & $2.8 \%$ & $2.0 \%$ & | $5.5 \%$ & $3.9 \%$ & $1.4 \%$ & $27.6 \%$ & $2.5 \%$ & $17.2 \%$ & - & $100.0 \%$ \\
\hline & China* & $8.2 \%$ & $2.6 \%$ & $15.0 \%$ & $2.9 \%$ & $2.4 \%$ & $8.2 \%$ & $1.8 \%$ & $11.9 \%$ & $3.6 \%$ & $9.2 \%$ & $20.2 \%$ & | $2.6 \%$ & $10.7 \%$ & - & $100.1 \%$ \\
\hline & Germany & $1.8 \%$ & $0.2 \%$ & $19.1 \%$ & $0.7 \%$ & $1.9 \%$ & I.1\% & $1.3 \%$ & $11.5 \%$ & | $1.5 \%$ & $3.4 \%$ & $9.4 \%$ & $8.0 \%$ & $39.7 \%$ & | $0.5 \%$ & $100.0 \%$ \\
\hline & India & - & - & - & - & - & - & - & - & - & - & - & - & - & - & - \\
\hline & Japan & $1.4 \%$ & $0.5 \%$ & $17.1 \%$ & $1.2 \%$ & $2.6 \%$ & $2.6 \%$ & $0.9 \%$ & $9.4 \%$ & $14.6 \%$ & $9.2 \%$ & $12.7 \%$ & $4.8 \%$ & $19.4 \%$ & & $100.0 \%$ \\
\hline & Mexico & - & - & - & - & - & - & - & - & - & - & - & - & - & - & - \\
\hline & UK & - & - & - & - & - & - & - & - & - & - & - & - & - & - & - \\
\hline \multirow{9}{*}{ 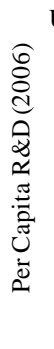 } & United States & 15.14 & 4.82 & 155.16 & 3.40 & 7.52 & 2.18 & 5.02 & 32.98 & 24.68 & 7.64 & 104.44 & 75.01 & 124.79 & - & 578.47 \\
\hline & Australia & 25.51 & 3.52 & 18.21 & 3.49 & 2.33 & 17.11 & 4.39 & 8.39 & 1.76 & 1.57 & | 7.66 & 14.61 & 29.81 & 1.00 & 139.36 \\
\hline & Canada & 32.74 & 3.49 & 37.49 & 1.39 & 1.28 & 6.39 & 4.58 & 12.82 & 9.04 & 3.22 & 63.95 & 5.73 & 39.80 & - & 231.37 \\
\hline & China & 1.02 & 0.33 & 1.86 & 0.36 & 0.29 & $\mid 1.01$ & 0.23 & 1.47 & $\mid 0.44$ & $\mid 1.14$ & 2.50 & 0.33 & 1.33 & - & 12.39 \\
\hline & Germany & 9.51 & 0.97 & 103.29 & 3.83 & 10.48 & 5.77 & 7.20 & 62.20 & 8.01 & 18.23 & 51.08 & 43.53 & 214.74 & 2.51 & 541.35 \\
\hline & India & - & - & - & - & - & - & - & - & - & - & - & - & - & - & - \\
\hline & Japan & 10.70 & 3.68 & 133.37 & 9.30 & 20.02 & 20.45 & 7.38 & 73.42 & 114.31 & 72.01 & 98.96 & 37.35 & 151.66 & - & 782.21 \\
\hline & Mexico & - & - & - & - & - & - & - & - & - & - & - & - & . & - & - \\
\hline & UK & - & - & - & - & - & - & . & - & - & - & - & - & - & - & - \\
\hline
\end{tabular}

$* \mathrm{R} \& \mathrm{D}$ data from China was unavailable for 2006. The data shown is adjusted from 2000 .

Note: The green bars represent a visual comparison between countries. For example, the U.S. has the largest $R \& D$ value for ISIC 15-22; therefore, it also has the longest green bar.

${ }^{59}$ Thomson Reuters. “Top 100 Global Innovators, 2011." < http://www.top100innovators.com/overview> 
Table 3.13: U.S. Research and Development Expenditures by Year, Percentile (OECD Structural Analysis Database)

\begin{tabular}{|c|c|c|c|c|c|c|c|c|c|c|c|c|c|c|c|c|}
\hline & & 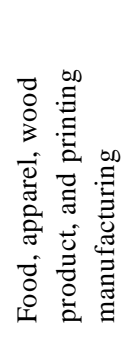 & 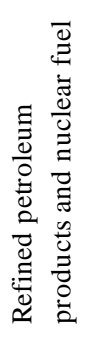 & 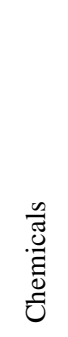 & 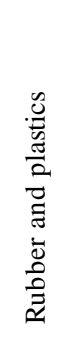 & 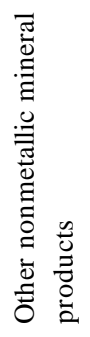 & 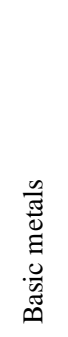 & 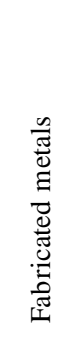 & 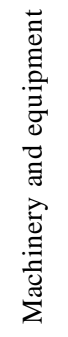 & 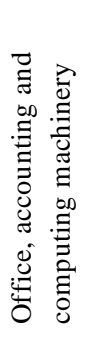 & 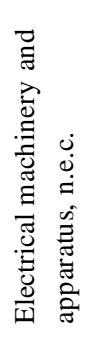 & 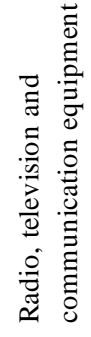 & 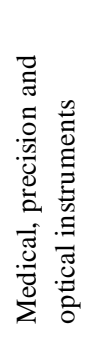 & 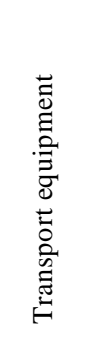 & 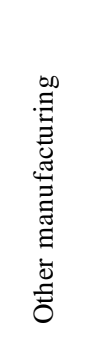 & 崖 \\
\hline \multirow{8}{*}{$\begin{array}{l}\stackrel{0}{\Xi} \\
\overrightarrow{0} \\
0 \\
0 \\
0 \\
\dot{0} \\
\dot{D} \\
\dot{D}\end{array}$} & ISIC & $15-22$ & 23 & 24 & 25 & 26 & 27 & 28 & 29 & 30 & 31 & 32 & 33 & $34-35$ & $36-37$ & \\
\hline & 2001 & 95.8 & 94.1 & 95.7 & 95.5 & 91.7 & 91.3 & 95.5 & 95.7 & 94.4 & 91.3 & 95.5 & 95.7 & 95.5 & 95.5 & 96.0 \\
\hline & 2002 & 95.8 & 95.2 & 95.8 & 91.3 & 91.7 & 91.7 & 95.5 & 95.8 & 94.7 & 91.7 & 95.7 & 95.8 & 95.7 & 95.5 & 96.0 \\
\hline & 2003 & 96.0 & 94.7 & 95.8 & 91.3 & 92.0 & 92.0 & 95.8 & 91.7 & 94.7 & 91.7 & 95.7 & 95.8 & 95.7 & 95.7 & 96.3 \\
\hline & 2004 & 96.2 & 94.4 & 96.0 & 91.3 & 91.7 & 91.7 & 95.8 & 91.7 & 94.7 & 92.0 & 96.0 & 96.0 & 95.8 & 95.7 & 96.2 \\
\hline & 2005 & 96.2 & 94.7 & 95.8 & 91.3 & 92.0 & 92.0 & 95.8 & 96.0 & 94.7 & 92.0 & 95.8 & 96.0 & 95.8 & 95.8 & 96.3 \\
\hline & 2006 & 96.0 & 94.7 & 95.8 & 91.3 & 92.0 & 92.0 & 95.8 & 95.8 & 94.7 & 92.0 & 95.8 & 96.0 & 95.7 & 95.5 & 96.0 \\
\hline & 2007 & 96.3 & 94.7 & 95.8 & 91.3 & 92.6 & 92.6 & 96.0 & 95.8 & 95.0 & 92.0 & 96.0 & 96.0 & 95.8 & 95.7 & 96.3 \\
\hline \multirow{9}{*}{ 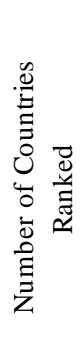 } & 2008 & 90.5 & - & 95.2 & 94.7 & 85.0 & 85.0 & 95.0 & 90.0 & 93.3 & 85.0 & 95.0 & - & 94.4 & - & 95.2 \\
\hline & 2001 & 24 & 17 & 23 & 22 & 24 & 23 & 22 & 23 & 18 & 23 & 22 & 23 & 22 & 22 & 25 \\
\hline & 2002 & 24 & 21 & 24 & 23 & 24 & 24 & 22 & 24 & 19 & 24 & 2 & 24 & 23 & 22 & 25 \\
\hline & 2003 & 25 & 19 & 24 & 23 & 25 & 25 & 24 & 24 & 19 & 24 & 23 & 24 & 23 & 23 & 27 \\
\hline & 2004 & 26 & 18 & 25 & 23 & 24 & 24 & 24 & 24 & 19 & 25 & 25 & 25 & 24 & 23 & 26 \\
\hline & 2005 & 26 & 19 & 24 & 23 & 25 & 25 & 24 & 25 & 19 & 25 & 24 & 25 & 24 & 24 & 27 \\
\hline & 2006 & 25 & 19 & 24 & 23 & 25 & 25 & 24 & 24 & 19 & 25 & 2 & 25 & 23 & 22 & 25 \\
\hline & 2007 & 27 & 19 & 24 & 23 & 27 & 27 & 25 & 24 & 20 & 25 & 25 & 25 & 24 & 23 & 27 \\
\hline & 2008 & 21 & 14 & 21 & 19 & 20 & 20 & 20 & 20 & 15 & 20 & 20 & 19 & 18 & 17 & 21 \\
\hline
\end{tabular}

Table 3.14: U.S. Research and Development per Capita by Year, Percentile (OECD Structural Analysis Database)

\begin{tabular}{|c|c|c|c|c|c|c|c|c|c|c|c|c|c|c|c|c|}
\hline & & 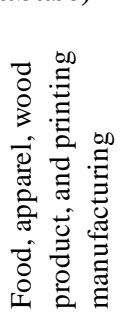 & 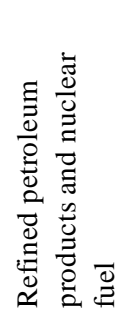 & $\begin{array}{l}\frac{n}{\tilde{J}} \\
.0 \\
\tilde{D} \\
\tilde{U}\end{array}$ & 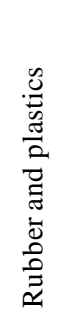 & 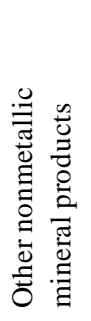 & 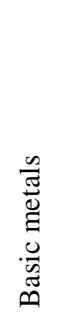 & 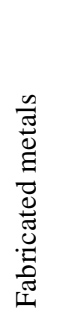 & 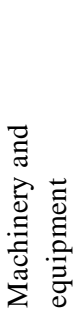 & 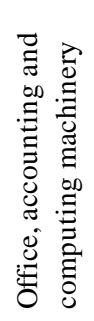 & 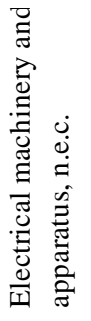 & 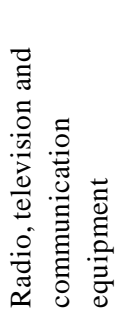 & 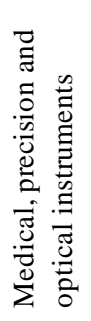 & 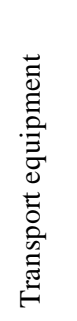 & 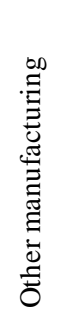 & $\begin{array}{l}\text { 它 } \\
\text { ○ } \\
\text { O }\end{array}$ \\
\hline \multirow{9}{*}{ 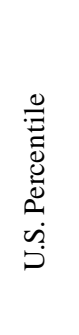 } & ISIC & $15-22$ & 23 & 24 & 25 & 26 & 27 & 28 & 29 & 30 & 31 & 32 & 33 & $34-35$ & $36-37$ & \\
\hline & 2001 & 87.5 & 82.4 & 73.9 & 81.8 & 79.2 & 39.1 & 86.4 & 82.6 & 83.3 & 87.0 & 81.8 & 91.3 & 86.4 & 81.8 & 92.0 \\
\hline & 2002 & 87.5 & 90.5 & 75.0 & 73.9 & 41.7 & 41.7 & 81.8 & 75.0 & 89.5 & 62.5 & 73.9 & 91.7 & 82.6 & 90.9 & 88.0 \\
\hline & 2003 & 88.0 & 89.5 & 79.2 & 73.9 & 56.0 & 56.0 & 70.8 & 75.0 & 89.5 & 58.3 & 73.9 & 91.7 & 91.3 & 82.6 & 88.9 \\
\hline & 2004 & 84.6 & 88.9 & 92.0 & 73.9 & 66.7 & 50.0 & 75.0 & 66.7 & 89.5 & 68.0 & 76.0 & 92.0 & 91.7 & 87.0 & 88.5 \\
\hline & 2005 & 88.5 & 84.2 & 95.8 & 69.6 & 60.0 & 52.0 & 66.7 & 80.0 & 89.5 & 60.0 & 75.0 & 92.0 & 87.5 & 87.5 & 92.6 \\
\hline & 2006 & 88.0 & 89.5 & 95.8 & 69.6 & 60.0 & 44.0 & 70.8 & 79.2 & 89.5 & 56.0 & 75.0 & 92.0 & 87.0 & 86.4 & 92.0 \\
\hline & 2007 & 88.9 & 94.7 & 95.8 & 69.6 & 55.6 & 51.9 & 68.0 & 75.0 & 85.0 & 56.0 & 76.0 & 92.0 & 87.5 & 87.0 & 92.6 \\
\hline & 2008 & 71.4 & - & 90.5 & 78.9 & 90.0 & 35.0 & 75.0 & 70.0 & 80.0 & 60.0 & 70.0 & - & 83.3 & - & 81.0 \\
\hline \multirow{8}{*}{ 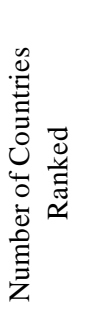 } & 2001 & 24 & 17 & 23 & 22 & 24 & 23 & 22 & 23 & 18 & 23 & 22 & 23 & 22 & 22 & 25 \\
\hline & 2002 & 24 & 21 & 24 & 23 & 24 & 24 & 22 & 2 & 10 & 24 & 23 & 2 & 23 & 22 & 25 \\
\hline & 2003 & 25 & 19 & 24 & 23 & 25 & 25 & 24 & 24 & 19 & 24 & 23 & 24 & 23 & 23 & 27 \\
\hline & 2004 & 26 & 18 & 25 & 23 & 24 & 24 & 24 & 24 & 19 & 25 & 25 & 25 & 24 & 23 & 26 \\
\hline & 2005 & 26 & 19 & 24 & 23 & 25 & 25 & 24 & 25 & 19 & 25 & 24 & 25 & 24 & 24 & 27 \\
\hline & 2006 & 25 & 19 & 24 & 23 & 25 & 25 & 24 & 24 & 19 & 25 & 24 & 25 & 23 & 22 & 25 \\
\hline & 2007 & 27 & 19 & 24 & 23 & 27 & 27 & 25 & 24 & 20 & 25 & 25 & 25 & 24 & 23 & 27 \\
\hline & 2008 & 21 & 14 & 21 & 19 & 20 & 20 & 20 & 20 & 15 & 20 & 20 & 19 & 18 & 17 & 21 \\
\hline
\end{tabular}


Table 3.15: U.S. Patents (OECD Patent Database)

\begin{tabular}{ccccc} 
Year & $\begin{array}{c}\text { Percent of } \\
\text { Total Patents }\end{array}$ & $\begin{array}{c}\text { Total Patents } \\
\text { Ranked } \\
\text { (Percentile) }\end{array}$ & $\begin{array}{c}\text { Patents per } \\
\text { Capita Rank } \\
\text { (Percentile) }\end{array}$ & $\begin{array}{c}\text { Number of } \\
\text { Countries } \\
\text { Ranked }\end{array}$ \\
\hline 1999 & $32.6 \%$ & $97.9 \%$ & $85.1 \%$ & 47 \\
2000 & $30.7 \%$ & $95.8 \%$ & $83.3 \%$ & 48 \\
2001 & $31.3 \%$ & $95.8 \%$ & $83.3 \%$ & 48 \\
2002 & $32.4 \%$ & $97.9 \%$ & $87.2 \%$ & 47 \\
2003 & $32.9 \%$ & $97.9 \%$ & $87.2 \%$ & 47 \\
2004 & $34.3 \%$ & $97.8 \%$ & $89.1 \%$ & 46 \\
2005 & $37.9 \%$ & $97.9 \%$ & $93.8 \%$ & 48 \\
2006 & $40.6 \%$ & $97.7 \%$ & $93.0 \%$ & 43 \\
2007 & $37.6 \%$ & $94.1 \%$ & $88.2 \%$ & 34
\end{tabular}

\subsection{World Bank}

The World Bank assists developing countries in financial and technical matters; however, it is not a bank in the traditional use of the term. It constitutes two institutions owned by 187 member countries: the International Bank for Reconstruction and Development (IBRD) and the International Development Association (IDA). The World Bank provides low-interest loans, interest-free credits, and grants to developing countries to invest in education, health, public administration, infrastructure, financial and private sector development, agriculture, and environmental and natural resource management. It also provides international data on various topics, including science and technology. The sources used to assemble this data includes the UNESCO Institute for Statistics, the U.S. National Science Board, the UN Statistics Division, the International Monetary Fund, and the World Intellectual Property Organization. ${ }^{60}$

As seen in Table 3.16, the U.S. ranks above the $85^{\text {th }}$ percentile for all 2000-2009 science and technology indicators shown with many indicators being above the $95^{\text {th }}$ percentile. The table also shows that the U.S. has the largest number of nonresident patent applications and the $2^{\text {nd }}$ largest number of resident applications (third largest for 2009) during the same time period with Japan having the largest. In per capita terms, the U.S. had the $4^{\text {th }}$ largest number of resident applications in 2000 and the $3^{\text {rd }}$ largest for 2001 to 2009. The U.S. maintains the largest number of scientific and technical journal articles ${ }^{61}$ between 2000 and 2007; however, it ranks between $12^{\text {th }}$ and $15^{\text {th }}$ in per capita terms. Although these statistics do not directly measure research and development or innovation performance, it provides a proxy for comparing the U.S. to nations abroad.

\footnotetext{
${ }^{60}$ World Bank. World Development Indicators. Washington DC, World Bank, 2011. <http://www.worldbank.org/>

${ }^{61}$ Scientific and technical journal articles are from journals classified by the Institute for Scientific Information. Specifically, it is from their Science Citation Index and Social Science Citation Index. Articles with authors from different countries are allocated proportionately. World Bank. World Development Indicators. Washington DC, World Bank, 2011. 314-317.
} 
Table 3.16: U.S. Science and Technology Indicators, Percentile (World Bank)

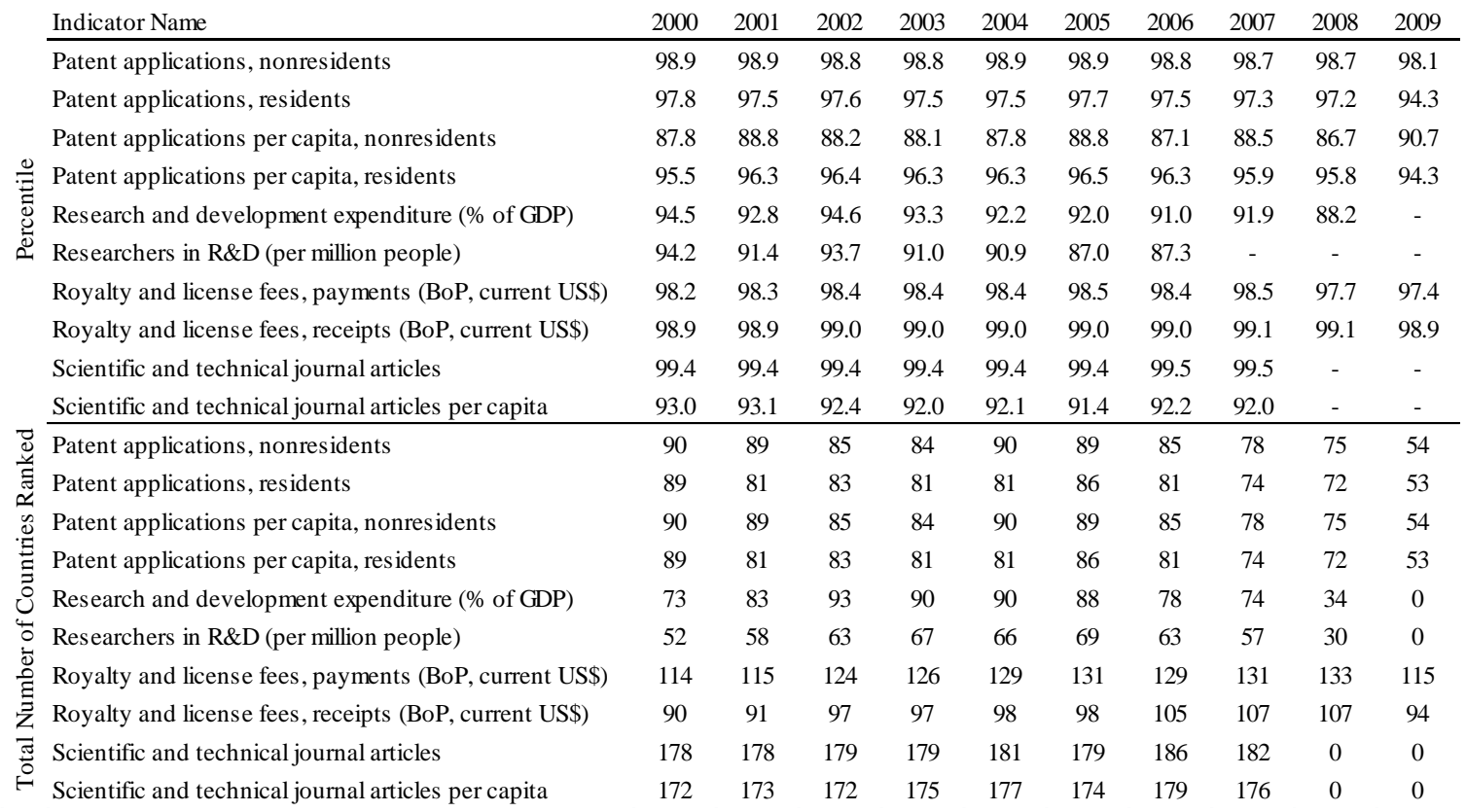

\subsection{International Comparative Indices}

A number of organizations assemble and publish comparative indices on national economies and manufacturing activities. These include UNIDO, the World Economic Forum, and the World Bank to name a few. These indices can be used to gain additional insight into the U.S. economy and the manufacturing industry. Data from some of the primary indices are discussed below. Many of the issues covered by these indices bleed into the category of the environment in which the manufacturing industry must operate rather than the trends and current state of manufacturing. However, these indices provide an international comparison of industry performance, labor productivity, and innovation among other things, providing a quantitative depiction of items related to the U.S. manufacturing industry.

UNIDO's Competitive Industrial Performance Index (CIP): The CIP index uses four variables to benchmark industrial activity at the country level. These variables include manufacturing value added per capita, manufacturing exports per capita, industrialization intensity (simple average of the share of manufacturing value added in gross domestic product and the share of medium and high-technology activities in manufacturing value added), and export quality (simple average of the share of manufactured exports in total exports and the share of medium and high-technology activities in manufactured exports). ${ }^{62}$

\footnotetext{
${ }^{62}$ UNIDO. "Industrial Development Scoreboard: Technical Notes." $<$ http://www.unido.org/index.php?id=5058>
} 
In 2003, Singapore was ranked number one in the Competitive Industrial Performance Index followed by Ireland, Switzerland, Japan, Belgium, Sweden, Finland, Germany, Korea, Taiwan Province, and France. The United States was ranked $12^{\text {th }}$ or around the $90^{\text {th }}$ percentile, as seen in Table 3.17. In terms of manufactured value added per capita, the U.S. ranked just below the $90^{\text {th }}$ percentile in 2003. The lowest ranking for the U.S. is its rank in the share of manufacturing value added in gross domestic product (GDP), which was below the $60^{\text {th }}$ percentile in 2003. With the exception of this category, the U.S. ranked above the $70^{\text {th }}$ percentile for all categories for all years.

Table 3.17: U.S. Competitive Industrial Performance Index Rankings (121 countries ranked)

\begin{tabular}{lccc|ccc} 
& \multicolumn{3}{c}{ Percentile } & \multicolumn{4}{c}{ Number of Countries Ranked } \\
& 1993 & 1998 & 2003 & 1993 & 1998 & 2003 \\
\hline Industrial Performance Index & 91.0 & 91.5 & 90.0 & 100 & 118 & 120 \\
Manufactured Value Added per Capita & 90.9 & 90.1 & 89.3 & 121 & 121 & 121 \\
Share of Manufacturing Value Added in GDP (Percentage) & 55.4 & 59.5 & 53.7 & 121 & 121 & 121 \\
Industrialization Intensity Indicator & 92.6 & 93.4 & 90.1 & 121 & 121 & 121 \\
Share of Medium- and High-tech Value Added in & 93.3 & 96.6 & 94.1 & 120 & 119 & 119
\end{tabular}

World Economic Forum's Global Competitiveness Report: The Global Competitiveness Report is a yearly report published by the World Economic Forum that ranks the world's nations according to the Global Competitiveness Index. This report is commonly cited inreference to competitiveness issues. The ranking uses a weighted average of multiple components, which are categorized into 12 pillars of economic competitiveness: institutions, infrastructure, macroeconomic environment, health and primary education, higher education and training, goods market efficiency, labor market efficiency, financial market development, technological readiness, market size, business sophistication, and innovation. ${ }^{63}$ Each pillar includes subcategories and the most recent ranking included 139 countries. Although this index measures the economy as a whole, it does provide insight into areas related to manufacturing.

The overall 2010-2011 Global Competitiveness Index rank for the U.S. was $4^{\text {th }}$ out of 139 countries. This is down from $2^{\text {nd }}$ in 2009-2010 and $1^{\text {st }}$ in 2008-2009. Figure 3.8 illustrates the rankings of the U.S. among the twelve pillars and the overall rank. The outer edge of the wheel represents a high ranking such as $1^{\text {st }}$ or $2^{\text {nd }}$ while the inner part represents a low ranking. Each spoke on the wheel has four tick marks representing $1^{\text {st }}, 47^{\text {th }}, 93^{\text {rd }}$, and $139^{\text {th }}$. Also included in this figure are nations that are the same countries listed in Table 3.2. These countries represent major U.S. trading partners, countries that are often considered competitors with the U.S., and nations that are similar to the U.S. Figure 3.8 is organized so that the overall rank is at the top followed by the 12 pillars in order from the highest ranking items for the U.S. to the lowest ranking items going in a clockwise fashion. The lowest ranking item is the macroeconomic environment and the highest ranking item is market size. The U.S. ranks $4^{\text {th }}$ in innovation, $4^{\text {th }}$ in labor market efficiency, and $17^{\text {th }}$ in technological readiness.

\footnotetext{
${ }^{63}$ World Economic Forum. The Global Competitiveness Report. 2010-2011. <http://www3.weforum.org/docs/WEF_GlobalCompetitivenessReport_2010-11.pdf>
} 
A more comprehensive table of the rankings is available in Appendix A. This table is organized into the twelve pillars and their subcategories ordered from highest ranking to lowest ranking. Subcategories ranking below the $70^{\text {th }}$ percentile are highlighted in yellow and subcategories ranking below the $50^{\text {th }}$ percentile are highlighted in red.

\section{IMD World Competitiveness Center's World Competitiveness Yearbook: The}

International Institute for Management Development (IMD) is a non-profit business school in Switzerland that has gained international recognition. The World Competitiveness Yearbook is a product of IMD's World Competitiveness Center. The Yearbook is a ranking of nations based on their ability to create and maintain an environment where enterprises can compete. This environment is broken into 4 factors: economic performance, government efficiency, business efficiency, and infrastructure. Each of these factors is broken into 5 sub-factors for a total of 20, which are given equal weight in determining overall rank among the 59 countries evaluated. There are over 300 criteria used to determine the sub-factors. According to the Yearbook, the U.S. ranked $1^{\text {st }}$ in overall competitiveness in 2011. It also ranked $1^{\text {st }}$ in domestic economy and scientific infrastructure. Its ranking for technology infrastructure was $2^{\text {nd }}$. A complete ranking of the U.S. and a selection of nations is available in Appendix B.

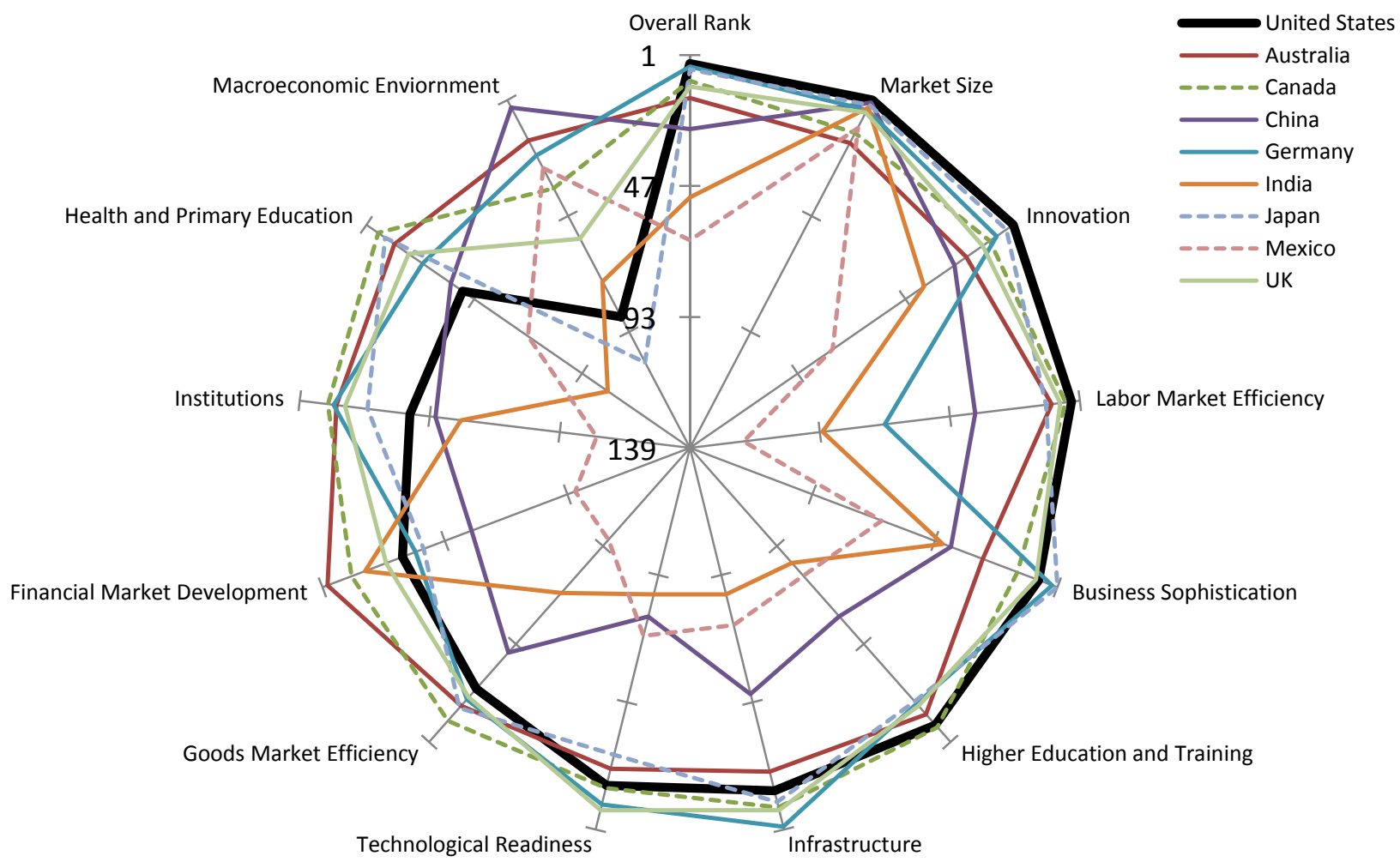

Figure 3.8: Global Competitiveness Index Ranking (139 countries) by Category, 2010-2011

Note: The outer edge of the wheel represents a high ranking such as $1^{\text {st }}$ or $2^{\text {nd }}$ while the inner part represents a low ranking. Each spoke on the wheel has four tick marks representing $1^{\text {st }}, 47^{\text {th }}, 93^{\text {rd }}$, and $139^{\text {th }}$. 


\section{Domestic Data}

This chapter presents data on the domestic U.S. manufacturing industry. The international data provided valuable context to the U.S. industry; however, more exhaustive data is available on the U.S. industry alone. These details include goods and services used by the industry; trends in subsector value added, net income, employment, and compensation; and subsector research and development expenditures. These items each contribute to depicting the U.S. manufacturing industry by providing more detailed information than is provided through international data.

As previously discussed, a successful industry might be considered one that has a suitable magnitude of production that results in competitive net benefits for its stakeholders. It is on this basis, to examine net benefits of U.S. stakeholders, that data was selected to be incorporated into this chapter. The data includes the total manufacturing value added, net income, compensation, and employment among other things. Although there are a number of sources for data, a few of them provide considerably more detail than others. The sources of data to be examined in this chapter include the Census Bureau; Bureau of Economic Analysis; Bureau of Labor Statistics; and the National Science Foundation. These are some of the most cited sources of domestic manufacturing data available. The Annual Survey of Manufactures from the Census Bureau provides detailed subsector data on value added, shipments, net income, depreciation of assets, compensation, and goods and services purchased by the manufacturing industry. It is among the most comprehensive datasets on the industry. The Census Bureau also provides shipment data through its Manufacturers' Shipments, Inventories, and Orders Survey. The Bureau of Economic Analysis provides a detailed accounting of manufacturing activity through its Annual Industry Accounts, including value added by industry and input-output data. This data provides a detailed account of the intermediate goods and services used by each subsector of the manufacturing industry. The Bureau of Labor Statistics provides data related to the compensation of employees, including employment, productivity, and wages. Finally, the National Science Foundation provides data on research and development expenditures, which reflects the advancement of the manufacturing industry. Each dataset in this chapter provides indispensable data relating to the net benefits received by manufacturing stakeholders.

\subsection{Census Bureau}

The Census Bureau has played a central role in tracking U.S. economic and demographic information since 1902 when it officially "opened its doors." The mission of the organization is "to serve as the leading source of quality data about the nation's people and economy." The Bureau provides three datasets relating to manufacturing activity: the Annual Survey of Manufactures, Economic Census, and the Manufacturers' Shipments, Inventories, and Orders Survey. 


\subsubsection{Annual Survey of Manufactures and the Economic Census}

The Annual Survey of Manufactures (ASM) is conducted every year except for years ending in 2 or 7 when the Economic Census is conducted. The ASM provides statistics on employment, payroll, supplemental labor costs, cost of materials consumed, operating expenses, value of shipments, value added, fuels and energy used, and inventories. It uses a sample survey of approximately 50000 establishments with new samples selected at 5year intervals. The ASM data allows the examination of multiple factors (value added, payroll, energy use, and more) of manufacturing at a detailed subsector level. The Economic Census, used for years ending in 2 or 7 , is a survey of all employer establishments in the U.S. that has been taken as an integrated program at 5-year intervals since 1967. Both the ASM and the Economic Census use NAICS classification; however, prior to NAICS the Standard Industrial Classification system was used. ${ }^{64}$

In 2009 , the total value of shipments in manufacturing was $\$ 4.44$ trillion. This figure represents the net selling value of products sold, transferred, or shipped on consignment. These products were made by or for an establishment (an establishment is a single physical location where manufacturing is conducted; this should not be confused with an enterprise or company) from material owned by the establishment. The figure for shipments requires careful interpretation as it includes the sale of intermediate as well as finished goods, which results in counting the value of some products twice. For instance, the value of an alternator for a car may be counted once when it is shipped to an auto assembly plant and once when the finished car is sold. The total value added is the best measure available for comparing the relative economic importance of manufacturing among other industries. Value added is equal to the value of shipments less the cost of materials, supplies, containers, fuel, purchased electricity, and contract work. It is adjusted by the addition of value added by merchandising operations plus the net change in finished goods and work-in-process goods. Value added avoids the duplication caused from the use of products of some establishments as materials. It is important to note that the BEA and the ASM calculate value added differently. The BEA calculates value added as "gross output (sales or receipts and other operating income, plus inventory change) less intermediate inputs (consumption of goods and services purchased from other industries or imported). ${ }^{\prime 65}$ Moreover, the difference is that ASM's calculation of value added includes purchases from other industries such as mining and construction while BEA's does not include it.

The ASM value added for all manufacturing was \$1 978.0 billion in 2009 . Approximately $9.8 \%$ of this value is computer and electronic product manufacturing as can be calculated from the data in Table 4.1. This sector increased $15.5 \%$ from $\$ 214.3$ billion in 1997 to $\$ 247.6$ billion in 2000. During the early 2000's recession it declined to a low of $\$ 182.9$ billion in 2002, but increased until the late 2000's recession as illustrated in Figure 4.1. It is important to note that the values in this figure were adjusted using the producer price index for each industry (sectors 333, 334, 335, and 336 were estimated for

\footnotetext{
${ }^{64}$ Census Bureau. "Annual Survey of Manufactures." < http://www.census.gov/manufacturing/asm/>

${ }^{65}$ Horowitz, Karen J. and Mark A. Planting. Concepts and Methods of the U.S. Input-Output Accounts. Bureau of Economic Analysis. 2006.
} 
1997 to 2002 using an average rate of change between 2003 and 2009). The selection of a price index is particularly important for sector 334 as the prices of computer and electronic products have declined while most other prices have increased. This sector is considered to be the high-tech manufacturing sector. ${ }^{66}$ If an increasing price index were used to adjust sector 334, it would appear as though the industry were in a constant decline. This is also the case for the semiconductor and related device manufacturing sector in Figure 4.2. This issue is complicated by uncertainty in the accuracy of the price

Figure 4.1: Value Added and Employment for Select Manufacturing Subsectors, Annual Survey of Manufactures (adjusted using industry specific PPI)

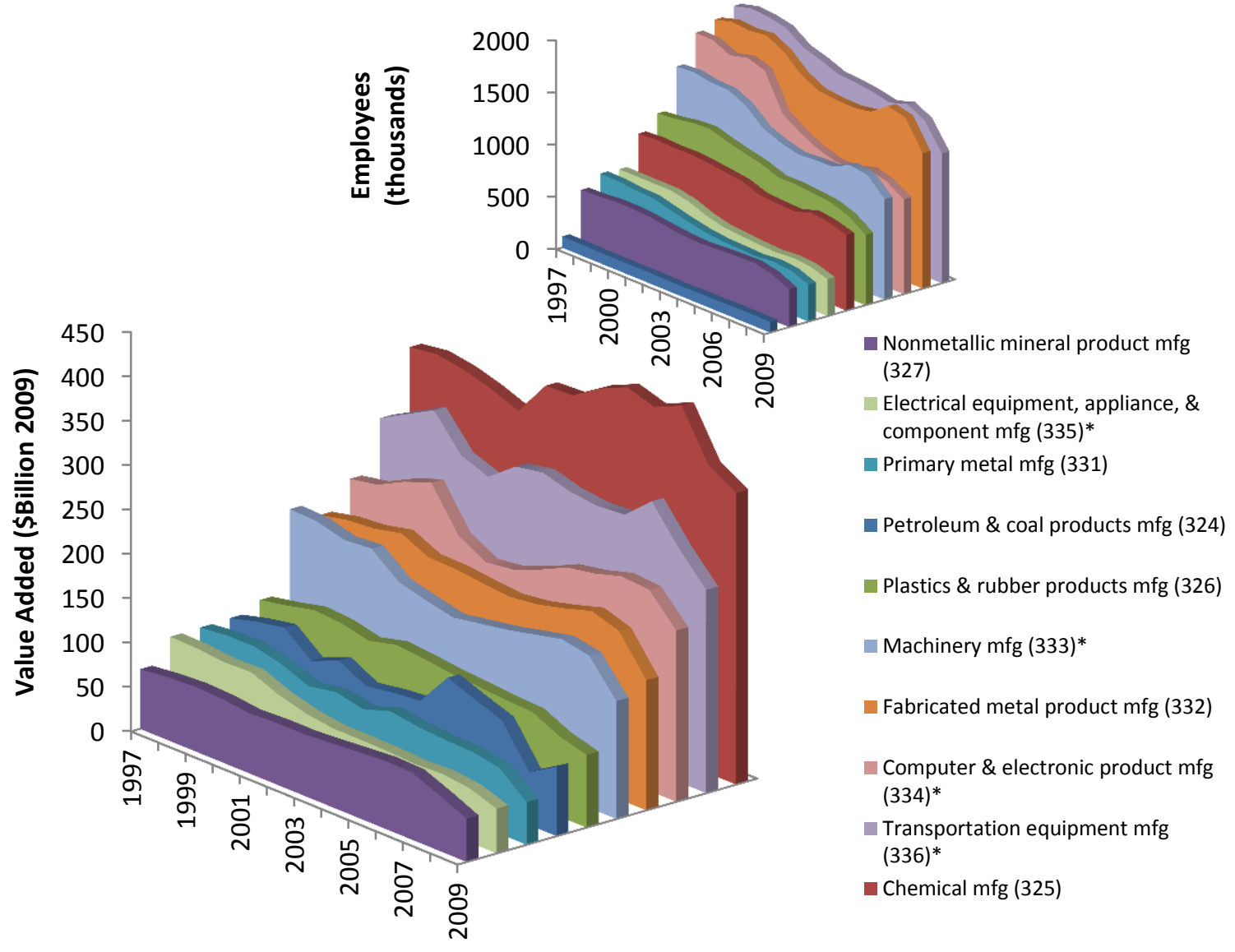

* The 1997 to 2002 PPI was estimated using the average annual price change between 2002 and 2009 Note: NAICS 311-323 (food, beverage, textile, apparel, paper, and printing), 337 (furniture and related products), and 339 (miscellaneous manufacturing) were omitted in order to allow a more detailed view of sectors related to medium- and high-tech manufacturing

\footnotetext{
${ }^{66}$ Kelley, Charles, Mark Wang, Gordon Bitko, Michael Chase, Aaron Kofner, Julia Lowell, James Mulvenon, David Ortiz, and Kevin Pollpeter. "High-Technology Manufacturing and U.S.

Competitiveness." RAND Technical Report. March 2004.

<http://www.rand.org/pubs/technical_reports/2004/RAND_TR136.pdf>
} 
Table 4.1: Subsectors of Manufacturing, Annual Survey of Manufactures 2009

\begin{tabular}{|c|c|c|c|c|c|c|c|c|c|}
\hline NAICS & & $\begin{array}{l}\text { Number of } \\
\text { Employees }\end{array}$ & $\begin{array}{l}\text { Compensation, } \\
\text { Payroll and } \\
\text { Benefits }(\$ 1000)\end{array}$ & $\begin{array}{l}\text { Value Added } \\
\qquad(\$ 1000)\end{array}$ & $\begin{array}{l}\text { Net Income } \\
\qquad(\$ 1000)\end{array}$ & $\begin{array}{c}\text { Compensation } \\
\text { per Employee } \\
(\$ 1000)\end{array}$ & $\begin{array}{c}\text { Value Added } \\
\text { per Employee } \\
(\$ 1000)\end{array}$ & $\begin{array}{c}\text { Net Income } \\
\text { per Employee } \\
(\$ 1000)\end{array}$ & $\begin{array}{l}\text { Net Income per } \\
\text { Expenditure } \\
\text { Dollar }\end{array}$ \\
\hline $311-323$ & Food, beverages, textiles, apparel, paper, and printing mfg & 3124186 & 156465345 & 511953541 & 213288376 & 50.1 & 163.9 & 68.3 & 0.24 \\
\hline 324 & Petroleum \& coal products mfg & 101559 & 11218562 & 78558603 & 23661442 & 110.5 & 773.5 & 233.0 & 0.05 \\
\hline 325 & Chemical mfg & 724683 & 62223691 & 328870852 & 181231086 & 85.9 & 453.8 & 250.1 & 0.43 \\
\hline 326 & Plastics \& rubber products mfg & 672794 & 35422443 & 82294714 & 17425905 & 52.6 & 122.3 & 25.9 & 0.12 \\
\hline 327 & Nonmetallic mineral product mfg & 360426 & 20716516 & 48899753 & 8520169 & 57.5 & 135.7 & 23.6 & 0.11 \\
\hline 331 & Primary metal mfg & 354831 & 24746316 & 48169964 & -4420471 & 69.7 & 135.8 & -12.5 & -0.03 \\
\hline 332 & Fabricated metal product mfg & 1296600 & 73269815 & 146876281 & 28875280 & 56.5 & 113.3 & 22.3 & 0.12 \\
\hline 333 & Machinery mfg & 962083 & 63539945 & 133056578 & 24575525 & 66.0 & 138.3 & 25.5 & 0.10 \\
\hline 334 & Computer \& electronic product mfg & 908299 & 76790501 & 193242334 & 51326615 & 84.5 & 212.8 & 56.5 & 0.19 \\
\hline 335 & Electrical equipment, appliance, \& component mfg & 352940 & 21800021 & 50498178 & 13768429 & 61.8 & 143.1 & 39.0 & 0.16 \\
\hline 336 & Transportation equipment $\mathrm{mfg}$ & 1240320 & 97895792 & 229642082 & 65962477 & 78.9 & 185.1 & 53.2 & 0.14 \\
\hline 337 & Furniture \& related product mfg & 360210 & 15968585 & 32235361 & 5710641 & 44.3 & 89.5 & 15.9 & 0.11 \\
\hline 339 & Miscellaneous mfg & 592410 & 35502295 & 93719105 & 29925935 & 59.9 & 158.2 & 50.5 & 0.27 \\
\hline $31-33$ & TOTAL Manufacturing & 11051341 & 695559827 & 1978017346 & 659851409 & 62.9 & 179.0 & 59.7 & 0.18 \\
\hline NAICS & & $\begin{array}{l}\text { Total Value of } \\
\text { Shipments } \\
(\$ 1000)\end{array}$ & $\begin{array}{l}\text { Value of } \\
\text { Production } \\
\text { (\$1000) }\end{array}$ & $\begin{array}{l}\text { Total Cost of } \\
\text { Materials } \\
(\$ 1000)\end{array}$ & $\begin{array}{c}\text { Cost of } \\
\text { Buildings and } \\
\text { Structures } \\
(\$ 1000)\end{array}$ & $\begin{array}{c}\text { Cost of } \\
\text { Machinery and } \\
\text { Equipment } \\
(\$ 1000)\end{array}$ & $\begin{array}{l}\text { Other Costs } \\
\qquad(\$ 1000)\end{array}$ & $\begin{array}{c}\text { Net } \\
\text { Inventories } \\
(\$ 1000)\end{array}$ & $\begin{array}{c}\text { Total } \\
\text { Depreciation of } \\
\text { Assets }(\$ 1000)\end{array}$ \\
\hline $311-323$ & Food, beverages, textiles, apparel, paper, and printing mfg & 1126141857 & 881701643 & 610779377 & 10066479 & 25426153 & 78964289 & -3180432 & 27971406 \\
\hline 324 & Petroleum \& coal products mfg & 497875474 & 467291734 & 419743225 & 2110750 & 16212310 & 18006887 & 480910 & 7403208 \\
\hline 325 & Chemical mfg & 628945803 & 425708250 & 296725926 & 5527042 & 17979903 & 43251688 & -3383289 & 18623178 \\
\hline 326 & Plastics \& rubber products mfg & 171185548 & 145963337 & 87355685 & 2176701 & 5144301 & 15864207 & -1561292 & 6235014 \\
\hline 327 & Nonmetallic mineral product mfg & 90395938 & 75662944 & 40196667 & 1012045 & 3871031 & 9866685 & -1272312 & 4940513 \\
\hline 331 & Primary metal mfg & 168297912 & 162676210 & 115973007 & 1476227 & 6917667 & 13562993 & -4190486 & 5851687 \\
\hline 332 & Fabricated metal product mfg & 281316544 & 240771991 & 130624569 & 4069076 & 7307373 & 25501158 & -3833336 & 7835937 \\
\hline 333 & Machinery mfg & 287634198 & 253369592 & 151115284 & 3244628 & 6531819 & 28937916 & -3345367 & 6343714 \\
\hline 334 & Computer \& electronic product mfg & 327991364 & 264672505 & 133896248 & 5625231 & 9830986 & 38529539 & -719347 & 11272897 \\
\hline 335 & Electrical equipment, appliance, \& component mfg & 106650713 & 88655438 & 54562019 & 1108437 & 2473749 & 8711212 & -1584368 & 2642478 \\
\hline 336 & Transportation equipment mfg & 545018370 & 469077710 & 319871616 & 3795734 & 11197690 & 36316878 & 4167802 & 14145985 \\
\hline 337 & Furniture \& related product mfg & 60826897 & 53375231 & 27927766 & 939685 & 859572 & 7679623 & -596674 & 1144351 \\
\hline 339 & Miscellaneous mfg & 143915487 & 110124550 & 49655914 & 2183976 & 3255938 & 19526427 & -562405 & 3302597 \\
\hline $31-33$ & TOTAL Manufacturing & 4436196105 & 3639051135 & 2438427303 & 43336011 & 117008492 & 344719502 & -19580596 & 117712965 \\
\hline
\end{tabular}

Note: The green bars represent a visual comparison between subsectors (listed in the left column) for each category (listed in the top row). Higher values have longer bars. 
Figure 4.2: Value Added and Employment for Semiconductor and Other Computer Component Manufacturing

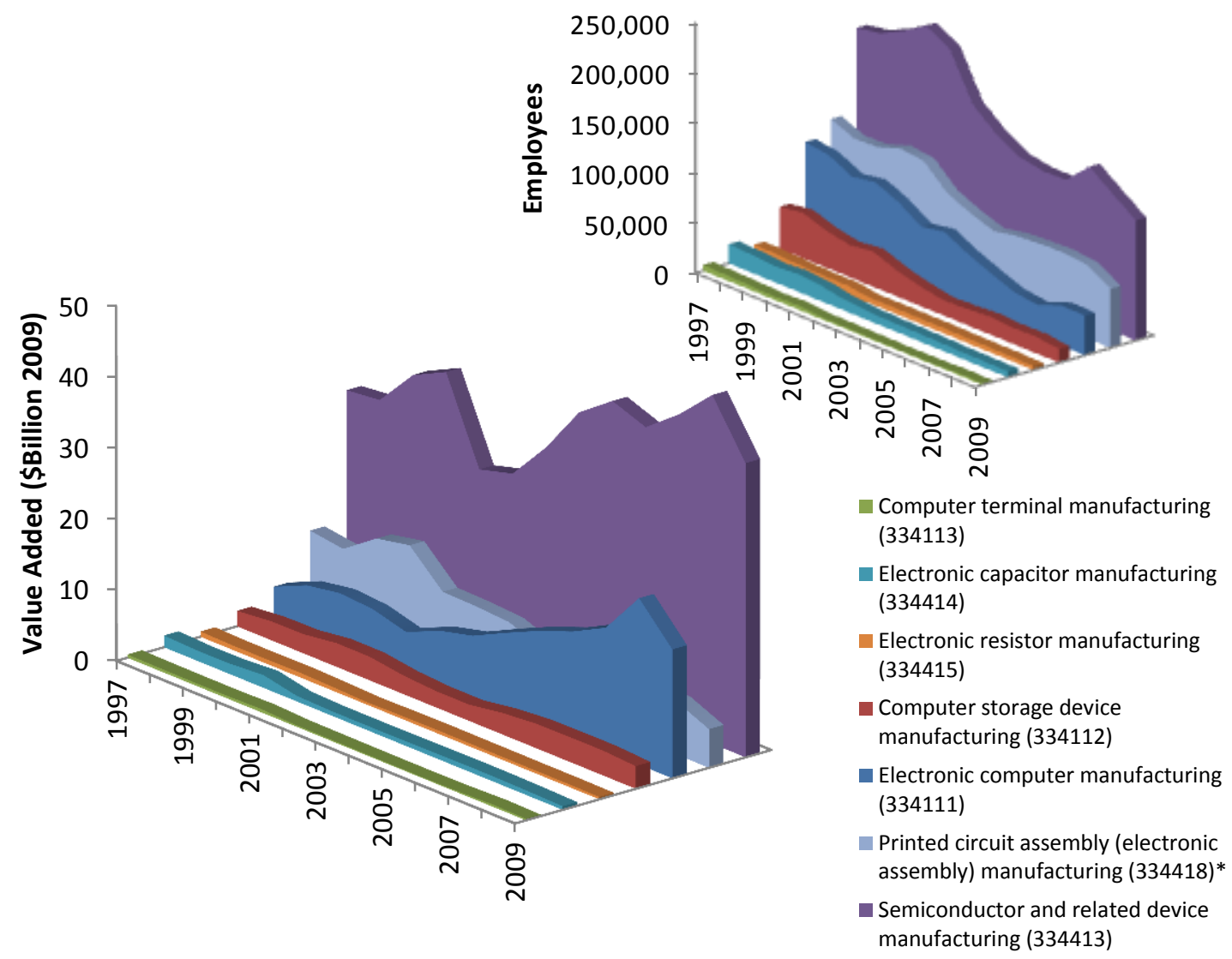

* The 1997 to 2002 PPI was estimated using the average annual price change between 2002 and 2009

indices available. Research by Houseman et $\mathrm{al}^{67}$ as well as Byrne et al ${ }^{68}$ has brought into question the accuracy of price measurement and its effect on measuring value added. For the time being, the BLS price indices are the best available for broad examination of the manufacturing industry.

Employment in semiconductor and related device manufacturing, as seen in Figure 4.2, has experienced a significant decline as have a number of other sectors. During the 1997 to 2009 period employment declined for all sectors shown in Figure 4.1: petroleum and coal products declined $6 \%$; chemicals $18 \%$; plastics and rubber $34 \%$; nonmetallic mineral products $28 \%$; primary metals $41 \%$; fabricated metal $26 \%$; machinery $32 \%$; computer and electronic products $46 \%$; electrical equipment, appliance, and components $41 \%$; and transportation $33 \%$. As seen in Figure 4.3, each subsector's 2009 proportion

\footnotetext{
${ }^{67}$ Houseman, Susan, Christopher Kurz, Paul Lengermann, and Benjamin Mandel. "Offshoring and the State of American manufacturing.” W.E. Upjohn Institute for Employment Research. June 2010 <http://www.upjohn.org/publications/wp/10-166.pdf>

${ }^{68}$ Byrne, David, Brian K. Kovak, and Bryan Michaels, "Offshoring and Price Measurement in the Semiconductor Industry." In Susan N. Houseman and Kenneth F. Ryder, eds., Measurement Issues Arising from the Growth of Globalization. (Washington, DC: National Academy of Public Administration, 2010): 169-194.
} 
Figure 4.3: Manufacturing Employment and Valued Added, 2009
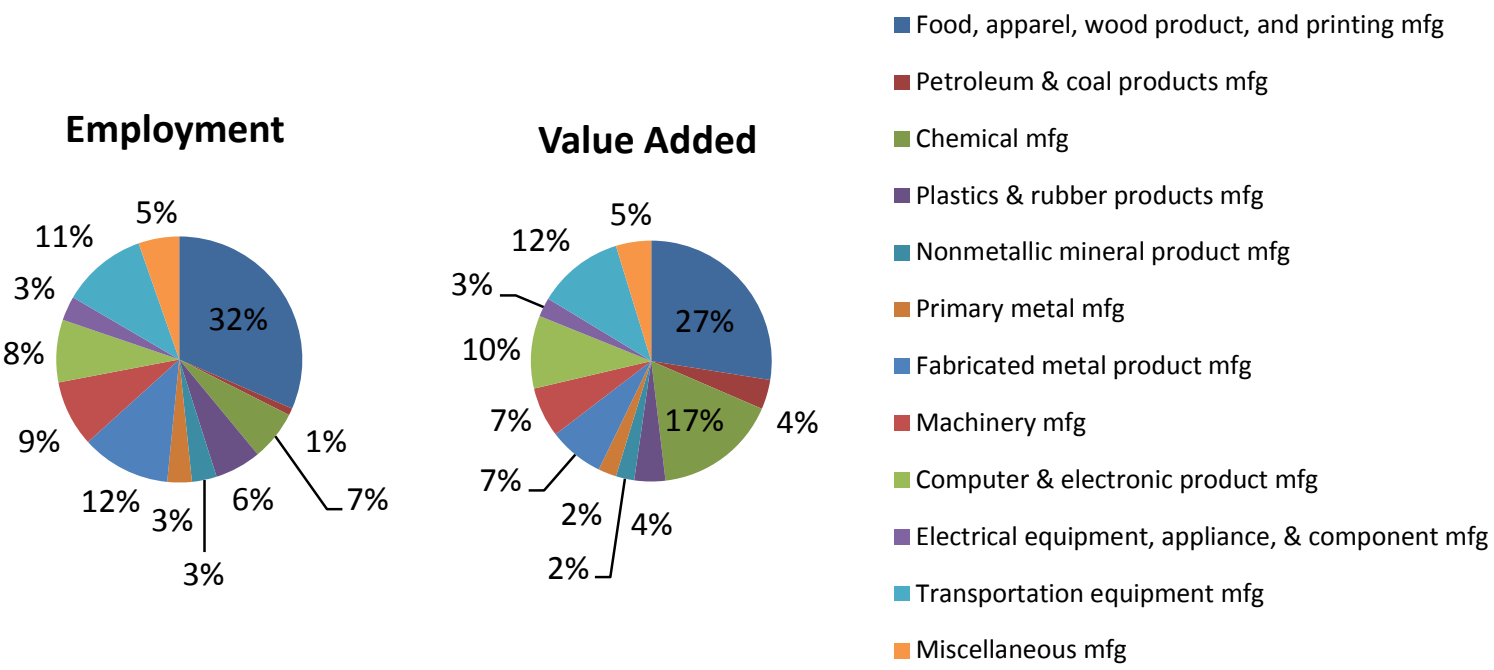

of employment and value added vary considerably. Computer and electronic manufacturing, for example, represents $8 \%$ of employment but $10 \%$ of value added. Chemical manufacturing represents $7 \%$ of employment and $17 \%$ of value added.

There has been some concern regarding the decline of manufacturing's share of GDP; however, this downward trend seems to pervade as far back as BEA data is available in 1947 through the manufacturing golden era of the 1950's and 1960's, ${ }^{69}$ as seen in Figure 4.4. During the same time period, expenditures on manufactured goods as a share of total expenditures declined. These downward trends suggest that the recent decline in manufacturing's share of GDP is not the sole result of recent trends in offshoring manufacturing activity. During the same time period, manufacturing value added has had an upward trend. As discussed later in this report, employment as a share of total employment has also had a downward trend (with the exception of the World War II era) going back as far as 1919.

Broad data covering the entire manufacturing industry is shown in Table 4.1 while detailed 2009 data is available in Appendix C, which contains the number of employees, value added, total value of shipments, net income, and other metrics for chemical manufacturing (NAICS 325); machinery manufacturing (NAICS 333); computer and electronic products manufacturing (NAICS 334); electrical equipment, appliance, and component manufacturing (NAICS 335); and transportation equipment manufacturing (NAICS 336) along with all the subsectors. According to this data, semiconductor and other electronic components manufacturing (NAICS 3344) is $3.0 \%$ of the manufacturing industry and has a net income per expenditure dollar ratio of 0.173 . Net income is the total value of shipments less all costs, depreciation, and compensation. Similar to previous tables, the green colored bars in Table 4.1 provide a visual comparison between industries. Chemical manufacturing represents a large proportion of manufacturing net

\footnotetext{
${ }^{69}$ Hopp, Wallace J. and Mark L. Spearman Factory Physics. Third Edition. (Long Grove, IL: Waveland Press, 2011): 37-38.
} 
Figure 4.4: Manufacturing as a Percent of GDP (BEA)

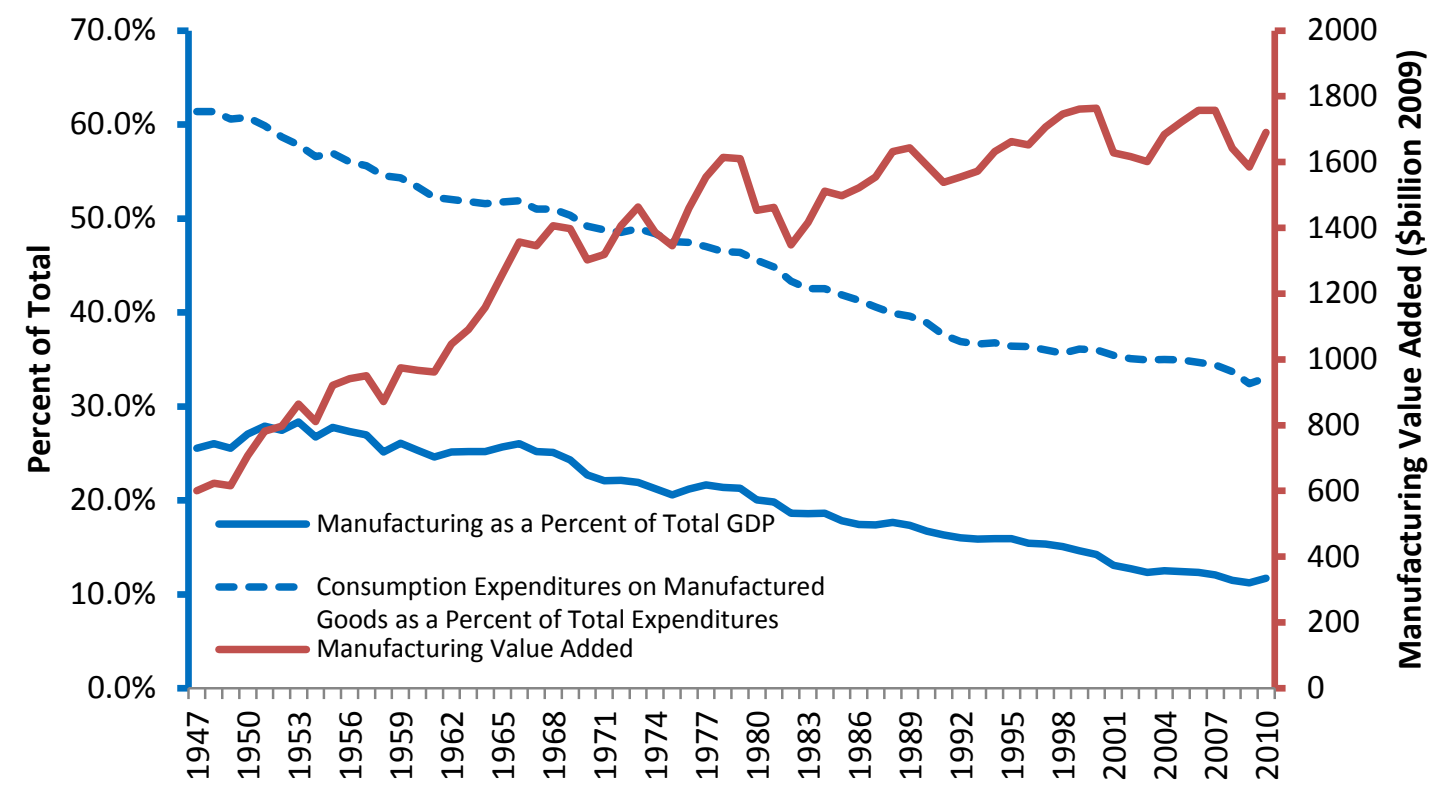

income and value added when compared to other manufacturing sectors. It also maintains the highest net income per expenditure dollar. Petroleum and coal products

manufacturing has the highest compensation per employee as well as the highest value added per employee. The value of production is the sum of all costs, including compensation. Sectors 311-323 have the largest value of production followed by transportation (336) and petroleum and coal (324). Net inventories is the sum of all end of year inventories less the sum of all the beginning of year inventories. Inventories need to be accounted for, as some sales are due to products produced in previous years.

Figure 4.5 brings together manufacturing data in a diagram of the manufacturing industry supply chain. The net income for all manufacturing is $\$ 777.6$ billion. The total value of production is $\$ 3639.1$ billion with $\$ 43.4$ billion for buildings. The items in blue represent purchased services, computer hardware, software, and other costs. Gold represents refuse removal, intermediate goods, and recycling while orange represents machinery, structures, and compensation with red being the repair of the machinery and structures. Green represents the total cost of materials. These items all feed into the design and production of goods that are inventoried and/or shipped. Purchased objects such as structures and computer equipment depreciate as shown in grey.

\subsubsection{Manufacturers' Shipments, Inventories, and Orders Survey}

The Manufacturers' Shipments, Inventories, and Orders survey provides monthly statistical data on current economic conditions and future production commitments in manufacturing. It includes establishments with $\$ 500$ million or more in annual shipments. The survey has been conducted monthly since 1957. Data in NAICS format are only available from 1992 onwards. Data between 1958 and 2000 is available in SIC format. Although these data provide information on inventories and orders, this report focuses on 
Figure 4.5: Manufacturing Industry Supply Chain, 2009

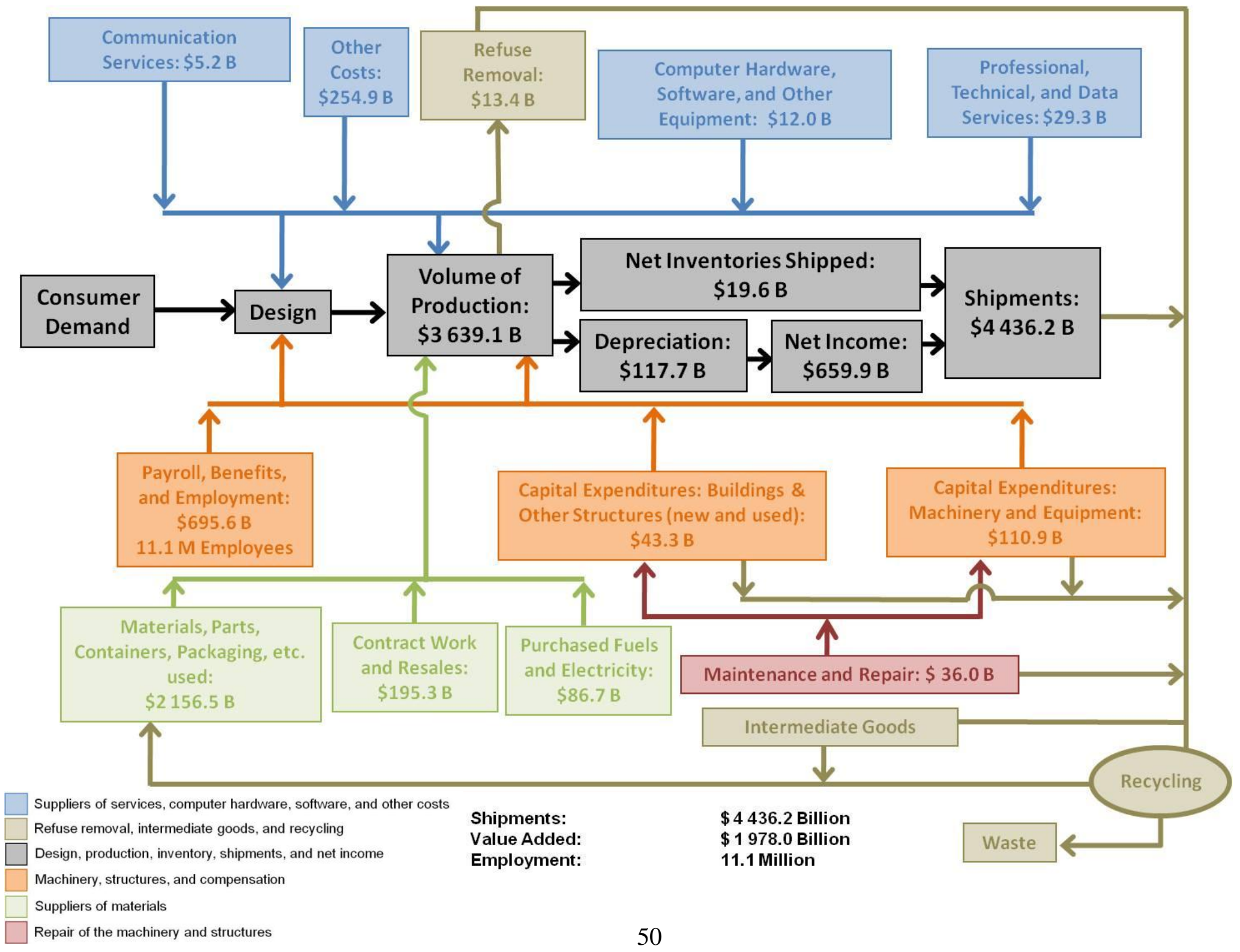


shipments. These data are more consistent with the annual survey of manufactures and BEA data, which also track shipments. ${ }^{70}$

As seen in Figure 4.6, manufacturing shipments have varied between 1958 and 2000; however, these have a general upward trend. Machinery and equipment as well as computer and office equipment manufacturing also appears to have a general upward trend as well. Automotive equipment seems to be increasing slightly. Although this figure is adjusted using the CPI for all goods and therefore does not accurately represent changes in the physical volume of production, it is the best representation possible since the PPI is not available for the same time span. The consumer price index has a strong upward trend with the exception of the 2008-2009 period where it decreased slightly. As mentioned previously, some products have decreased in price; these include computer and electronic products. It is possible, therefore, that shipments of computer and office equipment in Figure 4.6 have increased more rapidly than otherwise shown.

As seen in Figure 4.7, food, apparel, wood product, and printing manufacturing represents a significant proportion of the manufacturing industry, which is consistent with previous data sets discussed. In 2009, it represented $26 \%$ of manufacturing (see pie charts in Figure 4.7); this is down from $31 \%$ in 1992. With the exception of food, apparel, wood product, and printing manufacturing, data was adjusted using sector specific PPI. As noted in the figure, sectors 333, 334, 335, 336 were adjusted using related subsectors. These PPI values were used because the PPI for the listed sector is available only for 2003 onwards. The pie charts were generated using unadjusted data so

Figure 4.6: Manufacturing Shipments, 1958-2000 (Manufacturers' Shipments, Inventories, and Orders Survey)

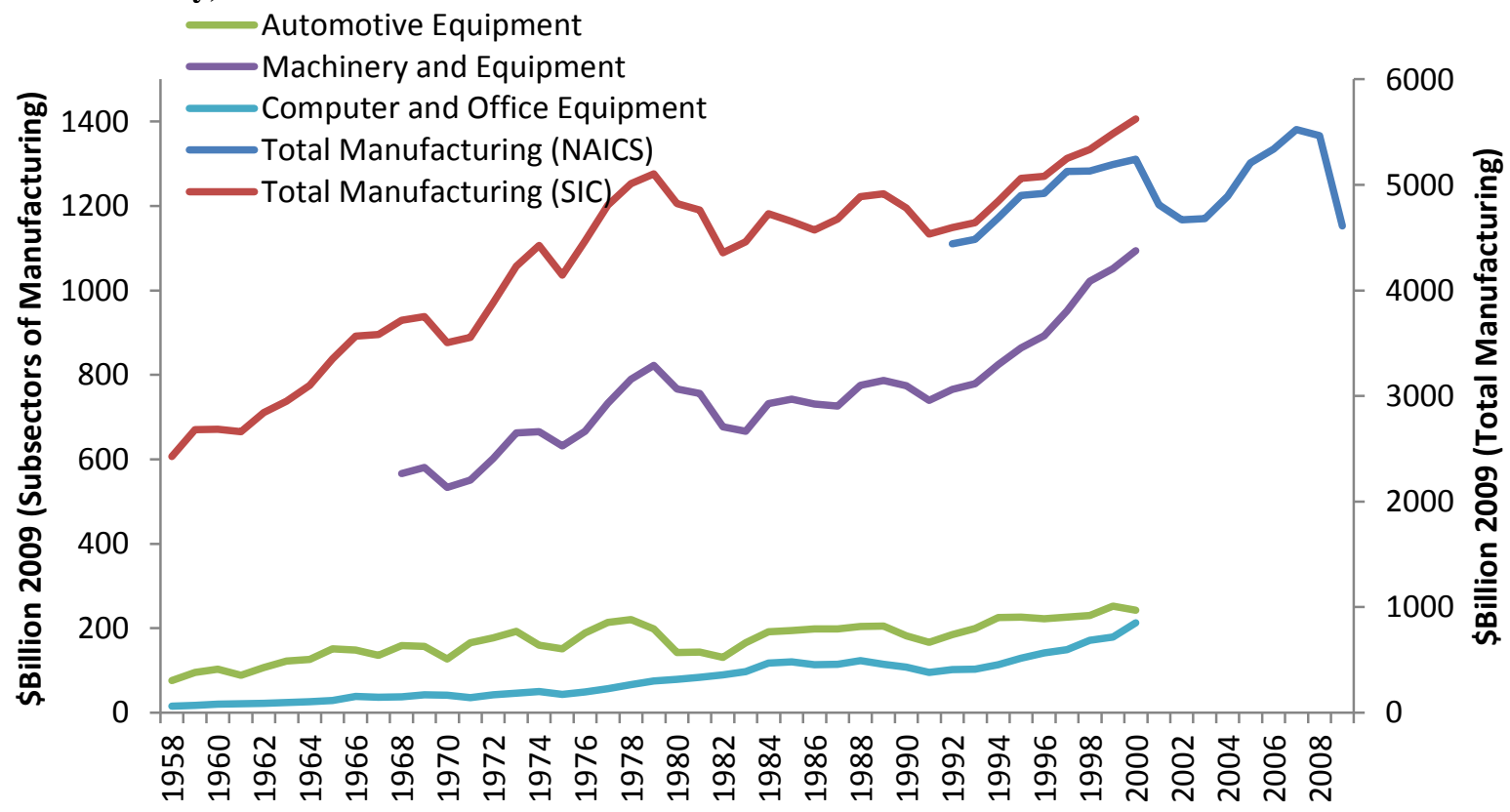

Note: Adjusted using the Consumer Price Index.

\footnotetext{
${ }^{70}$ Census Bureau. "Manufacturers' Shipments, Inventories, and Orders." <http://www.census.gov/manufacturing/m3/>
} 
Figure 4.7: Manufacturing Shipments, 1992-2009 (Manufacturers' Shipments, Inventories, and Orders Survey)
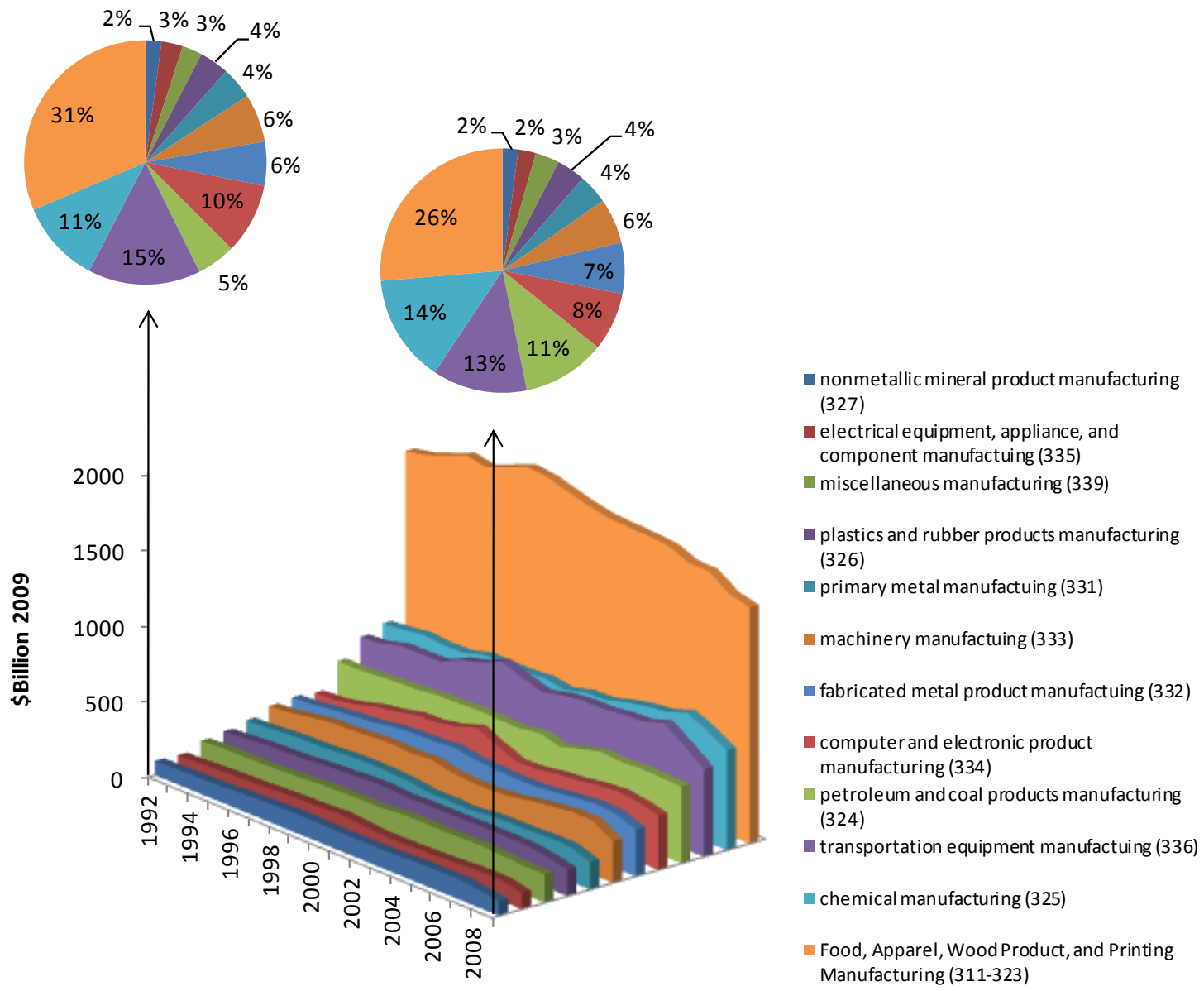

nonmetallic mineral product manufacturing
$(327)$
electrical equipment, appliance, and
component manufactuing (335)
miscellaneous manufacturing (339)
plastics and rubber products manufacturing
(326)
primary metal manufactuing (331)
machinery manufactuing (333)
fabricated metal product manufactuing (332)
computer and electronic product
manufacturing (334)
petroleum and coal products manufacturing
(324)
transportation equipment manufactuing (336)
chemical manufacturing (325)
Food, Apparel, Wood Product, and Printing
Manufacturing (311-323)

* Sectors 333, 334, 335, and 336 were adjusted using the PPI for sectors 3332, 3342, 3352, and 336991 Note: Pie charts were created using unadjusted data

as to maintain proportional relationships. Computer and electronic product manufacturing represents $8 \%$ of manufacturing shipments down from $10 \%$ in 1992 . This decline may be due to changes in the price of computer and electronic product manufacturing and not due to a decline in the volume of physical production. This industry grew by $47 \%$ between 1992 and 2009, faster than any other industry shown in Figure 4.7.

Transportation equipment manufacturing; machinery manufacturing; and electrical equipment, appliances, and component manufacturing represent $13 \%$ (down from $15 \%$ in 1992), $6 \%$ (the same as 1992), and $2 \%$ (down from $3 \%$ in 1992), respectively. These industries grew $10.5 \%, 14.0 \%$, and $19.4 \%$, respectively.

\subsection{Bureau of Economic Analysis}

The Bureau of Economic Analysis (BEA) is an entity of the Department of Commerce that produces national, regional, and industry data that depict economic growth and 
interindustry relationships. ${ }^{71}$ This report utilizes two BEA data sets: gross domestic product by industry and the input-output accounts. The GDP by industry accounts provide estimates of value added by industry, which is defined as gross sales (sales or receipts and other operating income, commodity taxes, and inventory change) less intermediate inputs (energy, raw materials, semi-finished goods, and purchased services). The BEA input-output data provides data on the interrelationships between industries. It provides data on how industries provide inputs and use outputs from each other to produce final goods and services to the end user. The Leontief input-output model provides a framework for utilizing BEA's input-output data; however, the data must be modified to be used in this type of analysis.

\subsubsection{Production}

BEA GDP by industry is available from 1947 to 2009; however, as discussed previously the producer price index is not available prior to 1985. Therefore, the consumer price index is used to adjust the values in Figure 4.8. As illustrated in this figure, U.S. GDP

Figure 4.8: U.S. GDP by Industry (\$billions 2009), BEA
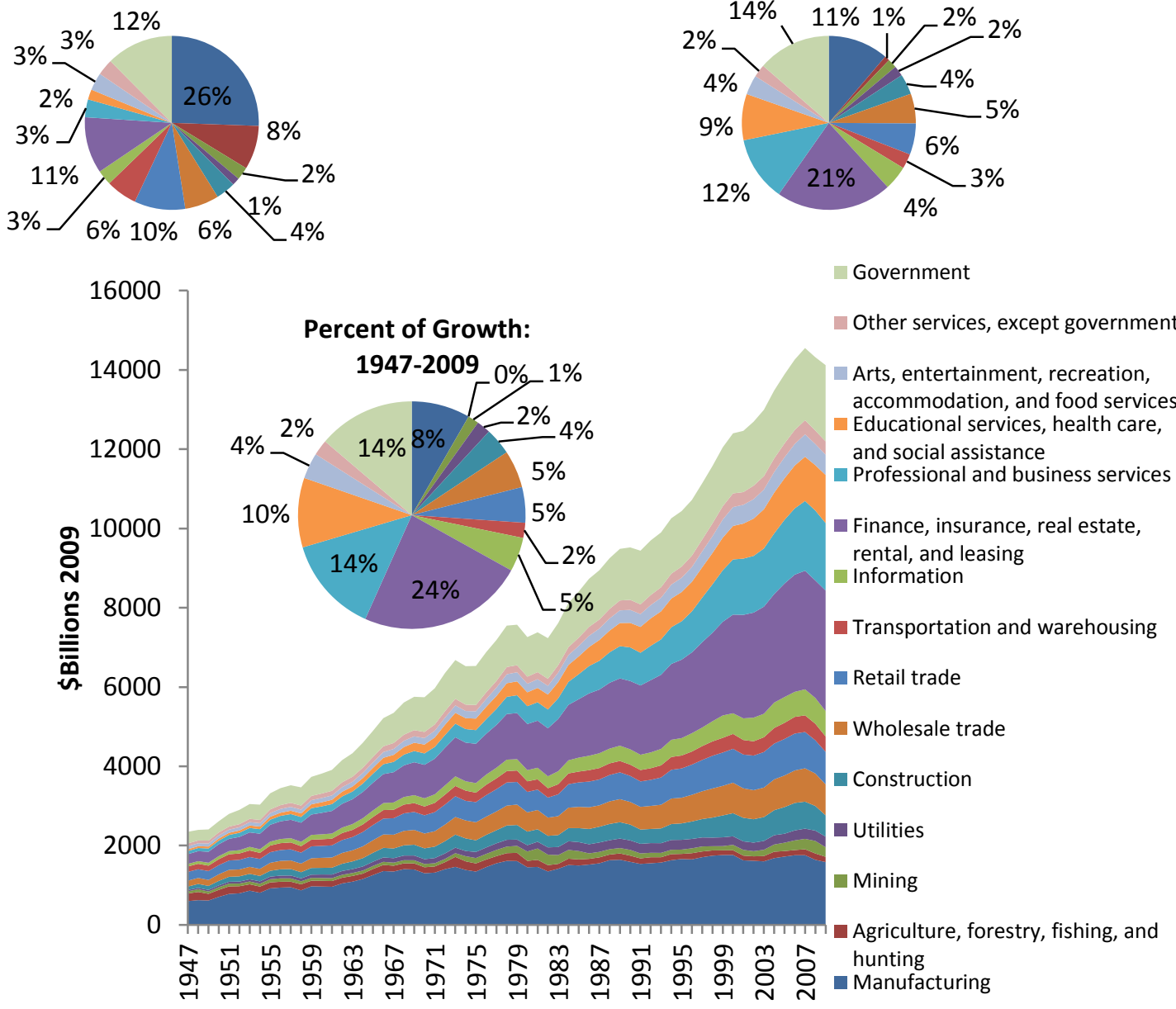

${ }^{71}$ Bureau of Economic Analysis. "U.S. Economic Accounts." <http://www.bea.gov/> 
grew $501 \%$ between 1947 and 2009 while manufacturing grew $164 \%$. As seen in Figure 4.9 , manufacturing's average annual ten year growth (10 year moving average) has declined from around $5 \%$ in 1957 to $-1 \%$ in 2009. During nearly the same period, the ratio of imported goods to manufacturing value added has increased from 0.11 in 1960 to 0.99 in 2009. Since manufacturing grew slower than the whole of the U.S. economy, it went from representing $26 \%$ of GDP to $11 \%$ of GDP (see Figure 4.8). Manufacturing represented $8 \%$ of growth while the largest growth sector was the finance, insurance, real estate, rental, and leasing sector with real estate representing the majority of this growth. The fastest growing sector was the educational services, health care, and social assistance sector followed by the professional and business services sector, growing $2641 \%$ and $2083 \%$. Approximately $63 \%$ of the professional and business services sector is professional, scientific, and technical services such as computer system design. Although the finance, insurance, real estate, rental, and leasing sector accounted for a larger percent of growth, it was the third fastest growing sector at $1134 \%$. With other industries growing faster and the real estate industry having grown to be larger than the whole of the manufacturing industry, it is important to note that in a world of limited and scarce resources that the growth of one industry may result in a decline in another industry. That is, resources might be diverted from one industry to be invested into another industry. ${ }^{72}$ It is also interesting to note that although real estate has grown by $148 \%$ between 1977 and 2009 , construction has only grown by $64 \%$. That is, the real estate industry is growing at a rapid rate while the constructed part of real estate seems to be changing a bit slower. Manufacturing value added as a ratio of shipments, as seen in Figure 4.10, provides a proxy for tracking U.S. activities involved in producing manufactured goods. As seen in the figure, this ratio has varied somewhat over time dipping during or near times of recession. Note that there was a recession in 1973-1975, 1980, 2001, and 2007-2009 during which times the ratio dips and recovers.

Food, apparel, wood product, and printing manufacturing made up $29 \%$ of manufacturing in 1977, as seen in Figure 4.11. It is important to note that this figure was adjusted using the consumer price index; therefore, it maintains proportional relationships

Figure 4.9: 10 Year Moving Average of Annual Growth in the Manufacturing Industry and Ratio of Imported Goods to Manufacturing Value Added

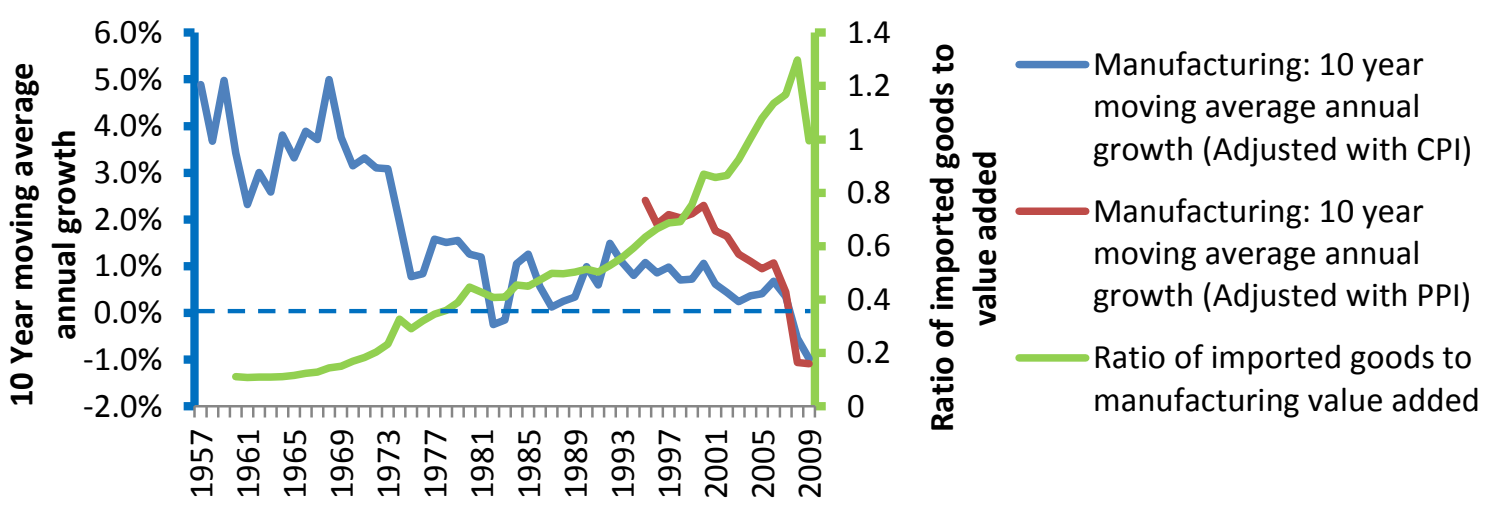

\footnotetext{
72 National Public Radio. “Stopping the 'Brain Drain' of the U.S. Economy.” February 6, 2012. <http://www.npr.org/2012/02/05/146434854/stopping-the-brain-drain-of-the-u-s-economy?ft=1\&f=100>
} 
but does not reflect changes in the physical volume of production over time. For example, comparing computer and electronic products manufacturing in Figure 4.11 with that of Figure 4.12, which uses the PPI for each industry, reveals that using the CPI for all items makes it appear that this industry declined $3.7 \%$ between 2000 and 2009. According to

Figure 4.10: Ratio of BEA Value Added to Shipments from the Manufacturers' Shipments, Inventories, and Orders Survey

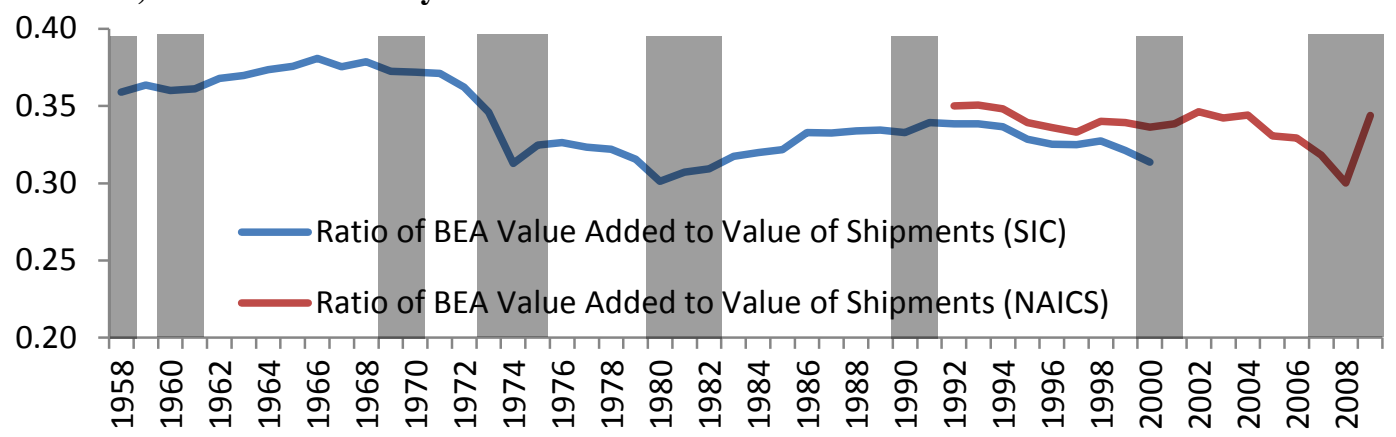

Note: Periods of recession are shown in grey.

Figure 4.11: Manufacturing GDP (BEA), 1977-2009

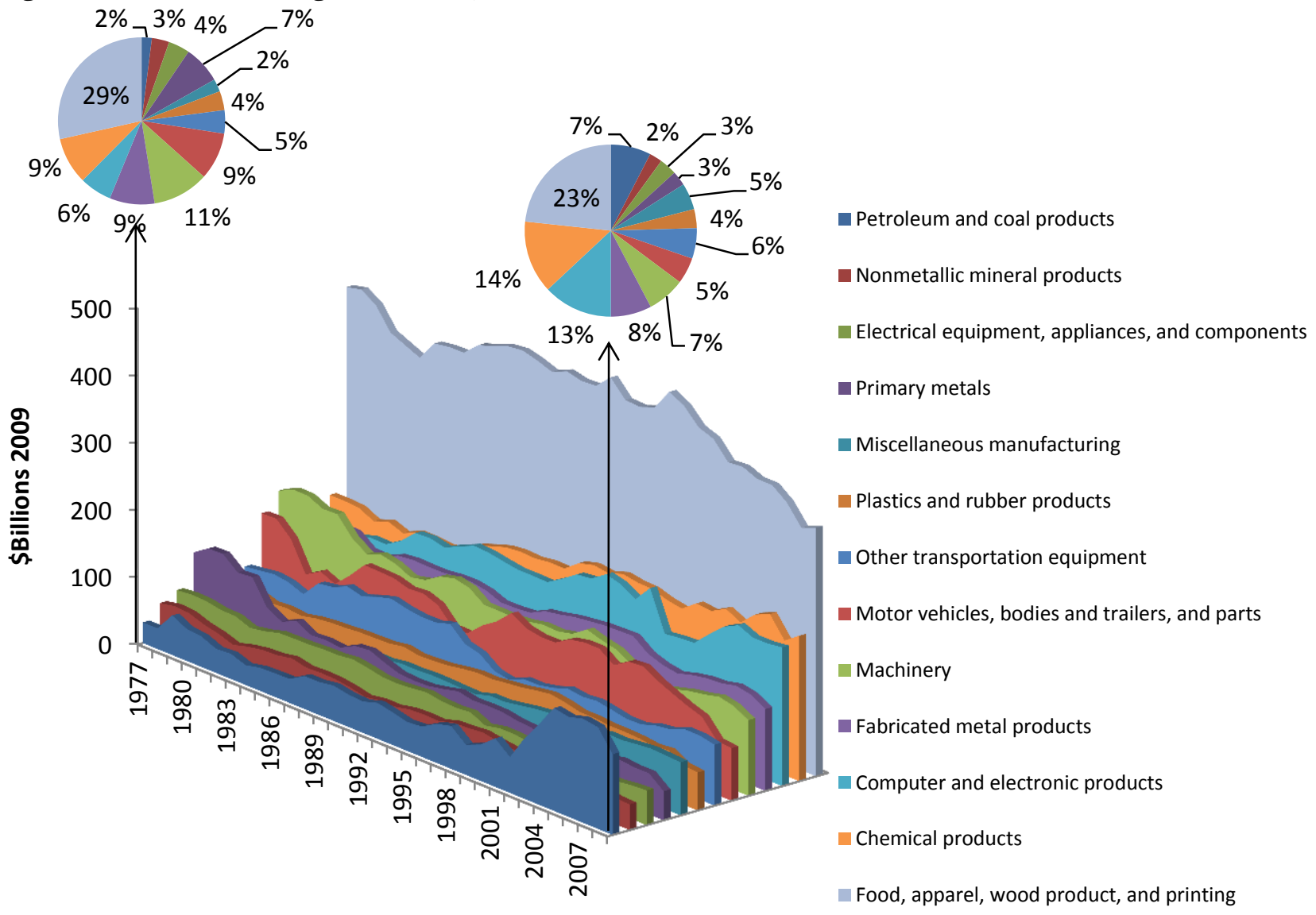

Note: Adjusted using the CPI for All Items 
Figure 4.12, however, the industry grew by $36.2 \%$ because of enhanced productivity. There is also a marked difference in petroleum and coal product manufacturing. Computer and electronic products represented $13 \%$ of manufacturing in 2009 up from $6 \%$ in 1977 and $12 \%$ in 2000 (not shown in Figure 4.11). Machinery was $7 \%$ in 2009, down from $11 \%$ in 1977 and $8 \%$ in 2000 (not shown in Figure 4.11). The manufacturing of motor vehicles, bodies and trailers, and parts was $5 \%$ in 2009 down from $9 \%$ in 1977 and $8 \%$ in 2000 (not shown in Figure 4.11). As discussed in the next section, according to Figure 4.12, which contains data adjusted using the PPI by industry, the computer and electronic product manufacturing industry grew by $36.2 \%$ between 2000 and 2009 . During this period, only the petroleum and coal products industry grew faster at $41.9 \%$. Between 1986 and 2009 computer and electronic products manufacturing grew $182.5 \%$, the largest growth of all manufacturing industries shown. Petroleum and coal were the second largest at $101.8 \%$. During this same period, motor vehicle, bodies and trailers, and parts manufacturing declined $12.7 \%$; however, most of this decline occurred between its peak in 2003 and 2009 where it declined $42.1 \%$.

Figure 4.12: Selected Manufacturing Industries GDP by Industry (BEA), 1986-2009
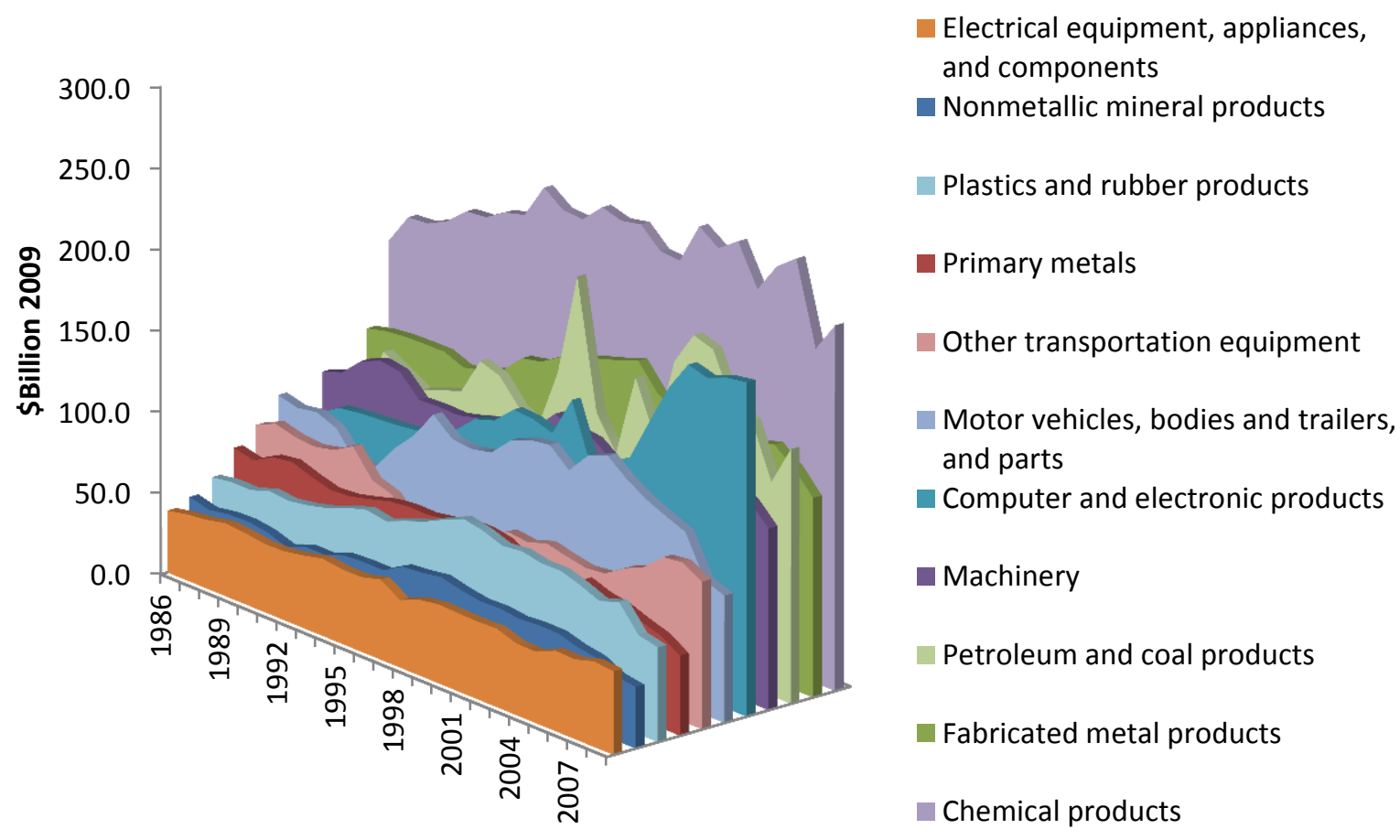

Note: Adjusted using the PPI by subsector

\subsubsection{Input-Output Accounts}

Annual input-output data is available from the BEA for the years 1998 through 2009. Prior to 1998, the data is available for every fifth year starting in 1967 . There is also data available for the years 1947, 1958, and 1963. More detailed data is available for years ending in two or seven. The input-output accounts provide data to analyze inter-industry relationships. 
BEA input-output data is provided in the form of make and use tables. Make tables show the production of commodities (products) by industry. Use tables show the components required for producing the output of each industry. There are two types of make and use tables: "standard" and "supplementary." Standard tables closely follow NAICS and are consistent with other economic accounts and industry statistics, which classify data based on establishment. Note that an "establishment" is a single physical location where business is conducted. This should not be confused with an "enterprise" such as a company, corporation, or institution. Establishments are classified into industries based on the primary activity within the NAICS code definitions. Establishments often have multiple activities. For example, a hotel with a restaurant has income from lodging, a primary activity, and from food sales, a secondary activity. An establishment is classified based on its primary activity. Data for an industry reflects all the products made by the establishments within that industry; therefore, secondary products are included.

Supplementary make-use tables reassign secondary products to the industry in which they are primary products. The data in this report utilizes supplementary make-use tables. ${ }^{73,74}$ The make-use tables are used for input-output analysis as developed by Wassily Leontief. Within this model, economies of scale are ignored; thus, it operates under constant returns to scale. The model also assumes that a sector uses inputs in fixed proportions. ${ }^{75}$ This report uses an industry-by-commodity format as outlined in Horowitz and Planting. This accounts for the fact that an industry may produce more than one commodity or product such as secondary and by-products. This calculation, however, does not take into account the fact that competitive imports are included in the make-use tables; therefore, to analyze the domestic manufacturing industry's interindustry relationships imports must be removed. This is done by subtracting imports proportionally throughout the use matrix.

Each manufacturing sector has two impacts: there are the goods and services purchased for use in the specified sector and then there are the goods and services that use products of the specified sector. The primary measure of output in the input-output accounts is gross output, which is similar to shipments from the Annual Survey of Manufactures. In general, gross output includes the value of both intermediate product and final product measured using market value (revenues received) for goods and services. With much of the data being from the Economic Census, the basic measure used for each industry varies, but is often referred to as "receipts." It is identified as shipments for mining and manufacturing, revenue for utilities, sales for merchant wholesale trade and retail trade, receipts for most services, and commissions for commodity brokerage. For the purpose of this report, it will simply be called output.

\footnotetext{
${ }^{73}$ Over the years BEA has made improvements to its methods. This includes redefining secondary products. The data discussed in this section utilizes the data BEA refers to as "after redefinitions."

${ }^{74}$ Horowitz, Karen J. and Mark A. Planting "Concepts and Methods of the U.S. Input-Output Accounts." 2009. <http://www.bea.gov/papers/pdf/IOmanual_092906.pdf>

${ }^{75}$ Miller, Ronald E. and Peter D. Blair. Input-Output Analysis: Foundations and Extensions. (New York: Cambridge University Press, 2009): 16.
} 
As seen in Table 4.2, the total impact of computer and electronic product manufacturing is $\$ 457.9$ billion or $1.9 \%$ of total output. That is, if all domestic computer and electronic manufacturing ceased to exist, total output would be $1.9 \%$ less. Food, beverage, and tobacco products have the largest impact with $\$ 1319.7$ billion or $5.3 \%$ of total output. Chemical product manufacturing is the second largest and petroleum and coal products are the third largest. Manufacturing's total impact on output is $\$ 5705.2$ billion or $23 \%$ of total output. It is important to note that the last entry of the column labeled "manufacturing products used" is left blank because this value is already accounted for in the column labeled "products used in the manufacturing industry." That is, the column labeled "B" has both the products an industry uses from other manufacturing industries as well as the products an industry uses from itself; thus, the sum of column " $\mathrm{D}$ " would represent the products an industry uses from itself, which is already accounted for in column "B." The item that is similar to shipments from the ASM is the total industry output, which is $\$ 4476$ billion. Table 4.3 provides a more detailed account of products used by the manufacturing industry; thus, the sum of the last row of the table (excluding the last column labeled manufacturing products, which is blank) equals the total in the column labeled "non-manufacturing products used" in Table 4.2. The last column is exactly the same as the column labeled "manufacturing products used" in Table 4.2. As seen in Table 4.3, the computer and electronic products sector used $\$ 975.8$ million of construction products, \$1 487.2 million of non-manufactured materials, \$14 339.5 million wholesale and retail trade services, $\$ 4875.5$ million in utilities, \$45 426.3 million of professional services, \$4 291.5 million of transportation and warehousing, \$12 271.7 million of other non-manufacturing, and \$35 169.4 million of manufacturing products (excluding computer and electronic products). The green colored bars in the table visually compare the value of the goods and services consumed by each manufacturing sector. For example, the computer and electronic products sector consumed more professional services than any other good or service; therefore, it has the longest bar. Table 4.4 has similar information for manufacturing products used by other industries. As seen in this table, professional services used \$15 542.7 million of computer and electronic products in 2009 and the manufacturing industry used \$276 061.9 million of computer and electronic products (including those products purchased from the computer and electronic industry for itself). As seen in Table 4.5, the manufacturing industry impacts $16.2 \%$ of value added with computer and electronic products impacting $1.8 \%{ }^{76}$

It is important to note, that there are additional services that support manufactured products in the marketplace. That is, technology support such as software and computer system design services purchased directly in the market place are not accounted for in Tables 4.2 through 4.5 because these purchases are not related to the manufacturing industry. These goods and services support both domestically produced goods and overseas produced goods. The computer systems design and related services sector (NAICS 5415) produced \$340 488.2 million in output associated with non-manufacturing

\footnotetext{
${ }^{76}$ The value added calculation assumes that the ratio of value added to output is constant for each subsector
} 
Table 4.2: Manufacturing Industry Impact on Output, 2009

\begin{tabular}{|c|c|c|c|c|c|c|c|c|c|c|c|c|c|}
\hline \multirow[b]{2}{*}{ NAICS } & \multirow[b]{2}{*}{ Industry } & A & $W$ & B & \multicolumn{2}{|c|}{$X \quad=\mathbf{A}+\mathbf{B}$} & $=W+X$ & $\mathbf{C}$ & $Y$ & D & $Z$ & $=\mathrm{A}+\mathrm{B}+\mathrm{C}+\mathrm{D}$ & $=W+X+Y+Z$ \\
\hline & & $\begin{array}{l}\text { Product Used in } \\
\text { Non- } \\
\text { Manufacturing } \\
\text { Industries } \\
\text { (\$million) }\end{array}$ & $\begin{array}{l}\text { As a } \\
\text { Percent } \\
\text { of Total } \\
\text { Output }\end{array}$ & $\begin{array}{l}\text { Product Used } \\
\text { in the } \\
\text { Manufacturing } \\
\text { Industry } \\
\text { (\$millions)* }\end{array}$ & $\begin{array}{l}\text { As a } \\
\text { Percent } \\
\text { of Total } \\
\text { Output }\end{array}$ & $\begin{array}{c}\text { Total Industry } \\
\text { Output } \\
\text { (\$millions) }\end{array}$ & $\begin{array}{l}\text { As a } \\
\text { Percent } \\
\text { of Total } \\
\text { Output }\end{array}$ & $\begin{array}{c}\text { Non- } \\
\text { Manufacturing } \\
\text { Products Used } \\
\text { (\$million) }\end{array}$ & $\begin{array}{c}\text { As a } \\
\text { Percent } \\
\text { of Total } \\
\text { Output }\end{array}$ & $\begin{array}{c}\text { Manufacturing } \\
\text { Products Used } \\
\text { (\$million)** }\end{array}$ & $\begin{array}{l}\text { As a } \\
\text { Percent } \\
\text { of Total } \\
\text { Output }\end{array}$ & $\begin{array}{c}\text { Total } \\
\text { Impact on } \\
\text { Output } \\
\text { (\$million) }\end{array}$ & $\begin{array}{c}\text { As a Percent } \\
\text { of Total } \\
\text { Output }\end{array}$ \\
\hline 321 & Wood products & 56252 & $0.23 \%$ & 22500 & $0.09 \%$ & 78751 & $0.32 \%$ & 5690 & $0.02 \%$ & 1677 & $0.01 \%$ & 86117 & $0.35 \%$ \\
\hline 327 & Nonmetallic mineral products & 63338 & $0.26 \%$ & 28212 & $0.11 \%$ & 91549 & $0.37 \%$ & 8548 & $0.03 \%$ & 2808 & $0.01 \%$ & 102905 & $0.41 \%$ \\
\hline 331 & Primary metals & 61153 & $0.25 \%$ & 117747 & $0.47 \%$ & 178901 & $0.72 \%$ & 9036 & $0.04 \%$ & 3323 & $0.01 \%$ & 191260 & $0.77 \%$ \\
\hline 332 & Fabricated metal products & 144349 & $0.58 \%$ & 155972 & $0.63 \%$ & 300321 & $1.21 \%$ & 21739 & $0.09 \%$ & 16342 & $0.07 \%$ & 338403 & $1.36 \%$ \\
\hline 333 & Machinery & 42356 & $0.17 \%$ & 213675 & $0.86 \%$ & 256031 & $1.03 \%$ & 82030 & $0.33 \%$ & 85909 & $0.35 \%$ & 423971 & $1.71 \%$ \\
\hline 334 & Computer and electronic products & 63024 & $0.25 \%$ & 276062 & $1.11 \%$ & 339086 & $1.37 \%$ & 83665 & $0.34 \%$ & 35169 & $0.14 \%$ & 457920 & $1.85 \%$ \\
\hline 335 & Eectrical equipment, appliances, and components & 30215 & $0.12 \%$ & 71481 & $0.29 \%$ & 101696 & $0.41 \%$ & 20821 & $0.08 \%$ & 23231 & $0.09 \%$ & 145749 & $0.59 \%$ \\
\hline 3361MV & Motor vehicles, bodies and trailers, and parts & 53069 & $0.21 \%$ & 294474 & $1.19 \%$ & 347543 & $1.40 \%$ & 104039 & $0.42 \%$ & 106156 & $0.43 \%$ & 557738 & $2.25 \%$ \\
\hline 3364OT & Other transportation equipment & 48256 & $0.19 \%$ & 195052 & $0.79 \%$ & 243308 & $0.98 \%$ & 80977 & $0.33 \%$ & 53282 & $0.21 \%$ & 377567 & $1.52 \%$ \\
\hline 337 & Furniture and related products & 13754 & $0.06 \%$ & 46211 & $0.19 \%$ & 59966 & $0.24 \%$ & 24047 & $0.10 \%$ & 18666 & $0.08 \%$ & 102679 & $0.41 \%$ \\
\hline 339 & Miscellaneous manufacturing & 33335 & $0.13 \%$ & 116073 & $0.47 \%$ & 149408 & $0.60 \%$ & 44217 & $0.18 \%$ & 34472 & $0.14 \%$ & 228096 & $0.92 \%$ \\
\hline $311 \mathrm{FT}$ & Food and beverage and tobacco products & 146379 & $0.59 \%$ & 629686 & $2.54 \%$ & 776065 & $3.13 \%$ & 431574 & $1.74 \%$ & 112025 & $0.45 \%$ & 1319664 & $5.32 \%$ \\
\hline 313TT & Textile mills and textile product mills & 8771 & $0.04 \%$ & 36306 & $0.15 \%$ & 45077 & $0.18 \%$ & 10497 & $0.04 \%$ & 10288 & $0.04 \%$ & 65863 & $0.27 \%$ \\
\hline 315AL & Apparel and leather and allied products & 1177 & $0.00 \%$ & 15818 & $0.06 \%$ & 16995 & $0.07 \%$ & 4295 & $0.02 \%$ & 3143 & $0.01 \%$ & 24433 & $0.10 \%$ \\
\hline 322 & Paper products & 68506 & $0.28 \%$ & 89693 & $0.36 \%$ & 158200 & $0.64 \%$ & 20875 & $0.08 \%$ & 10808 & $0.04 \%$ & 189882 & $0.77 \%$ \\
\hline 323 & Printing and related support activities & 76632 & $0.31 \%$ & 15374 & $0.06 \%$ & 92006 & $0.37 \%$ & 4929 & $0.02 \%$ & 2728 & $0.01 \%$ & 99663 & $0.40 \%$ \\
\hline 324 & Petroleum and coal products & 219928 & $0.89 \%$ & 253656 & $1.02 \%$ & 473583 & $1.91 \%$ & 95416 & $0.38 \%$ & 10440 & $0.04 \%$ & 579439 & $2.34 \%$ \\
\hline 325 & Chemical products & 154278 & $0.62 \%$ & 446413 & $1.80 \%$ & 600691 & $2.42 \%$ & 156909 & $0.63 \%$ & 68586 & $0.28 \%$ & 826185 & $3.33 \%$ \\
\hline 326 & Plastics and rubber products & 75908 & $0.31 \%$ & 91754 & $0.37 \%$ & 167662 & $0.68 \%$ & 19061 & $0.08 \%$ & 21391 & $0.09 \%$ & 208113 & $0.84 \%$ \\
\hline $32-33$ & TOTAL Manufacturing & 1360680 & $5.49 \%$ & 3116159 & $12.56 \%$ & 4476839 & $18.05 \%$ & 1228364 & $4.95 \%$ & - & - & 5705203 & $23.00 \%$ \\
\hline
\end{tabular}


Table 4.3: Products Used by Manufacturing Subsectors (\$millions 2009)

\begin{tabular}{|c|c|c|c|c|c|c|c|c|c|}
\hline NAICS & Industry & Construction & $\begin{array}{c}\text { Non- } \\
\text { Manufactured } \\
\text { Materials } \\
\end{array}$ & $\begin{array}{c}\text { Wholesale and } \\
\text { Retail Trade }\end{array}$ & Utilities & $\begin{array}{l}\text { Professional } \\
\text { Services }\end{array}$ & $\begin{array}{c}\text { Transportation } \\
\text { and } \\
\text { Warehousing }\end{array}$ & $\begin{array}{c}\text { Other Non- } \\
\text { Manufacturing }\end{array}$ & $\begin{array}{c}\text { Manufacturing } \\
\text { Products } \\
\text { (\$million)* }\end{array}$ \\
\hline 321 & Wood products & 122.5 & 1188.5 & 786.1 & 444.1 & 2043.2 & 597.7 & 507.4 & 1676.7 \\
\hline 327 & Nonmetallic mineral products & 208.8 & 1316.9 & 681.0 & 967.1 & 3311.3 & 1310.1 & 752.5 & 2807.7 \\
\hline 331 & Primary metals & 280.4 & 1338.4 & 1010.6 & 1041.4 & 3398.3 & 1173.9 & 793.1 & 3323.0 \\
\hline 332 & Fabricated metal products & 498.2 & 1039.2 & 2607.6 & 2049.2 & 11609.7 & 1910.8 & 2024.7 & 16342.3 \\
\hline 333 & Machinery & 1586.7 & 3039.2 & 14507.9 & 6342.7 & 42695.2 & 6790.0 & 7068.6 & 85909.1 \\
\hline 334 & Computer and electronic products & 975.8 & 1487.2 & 14339.5 & 4875.5 & 45423.3 & 4291.5 & 12271.7 & 35169.4 \\
\hline 335 & Electrical equipment, appliances, and components & 420.6 & 1157.7 & 4182.1 & 1735.0 & 9746.0 & 1848.1 & 1732.0 & 23231.2 \\
\hline 3361MV & Motor vehicles, bodies and trailers, and parts & 1944.2 & 5466.4 & 21291.1 & 8088.4 & 49360.4 & 9719.6 & 8169.0 & 106156.4 \\
\hline 3364OT & Other transportation equipment & 1129.8 & 2011.2 & 9136.1 & 5182.1 & 51006.0 & 5491.3 & 7020.1 & 53281.9 \\
\hline 337 & Furniture and related products & 510.8 & 1169.2 & 3800.1 & 2032.8 & 11828.5 & 2499.1 & 2206.2 & 18666.1 \\
\hline 339 & Miscellaneous manufacturing & 762.0 & 1591.9 & 6236.3 & 3442.0 & 24485.2 & 3746.0 & 3953.1 & 34472.2 \\
\hline 311FT & Food and beverage and tobacco products & 5875.5 & 158251.2 & 54359.0 & 25882.6 & 131437.5 & 33487.8 & 22280.5 & 112025.2 \\
\hline 313TT & Textile mills and textile product mills & 207.0 & 1053.8 & 1921.6 & 1173.8 & 4211.5 & 1048.2 & 881.6 & 10288.0 \\
\hline 315AL & Apparel and leather and allied products & 55.2 & 248.1 & 859.1 & 326.2 & 2134.8 & 361.5 & 309.8 & 3143.3 \\
\hline 322 & Paper products & 590.3 & 1877.4 & 3218.1 & 2877.1 & 7906.7 & 2379.7 & 2025.4 & 10808.1 \\
\hline 323 & Printing and related support activities & 113.4 & 146.1 & 535.7 & 453.9 & 2726.3 & 405.6 & 547.9 & 2727.6 \\
\hline 324 & Petroleum and coal products & 3229.5 & 63007.6 & 7604.4 & | 2593.6 & 13072.8 & 3864.6 & 2043.5 & 10439.9 \\
\hline 325 & Chemical products & 3281.5 & 18048.1 & 21600.3 & 15435.9 & 74999.9 & 11794.7 & 11748.1 & 68585.6 \\
\hline 326 & Plastics and rubber products & 466.9 & 1284.1 & 2693.2 & 2080.2 & 9033.0 & 1688.7 & 1814.8 & 21390.6 \\
\hline 32-33 & TOTAL Manufacturing & 22259.1 & 264722.3 & 171369.9 & 87023.7 & 500429.6 & 94408.8 & 88150.1 & - \\
\hline
\end{tabular}

* Excluding specified industry

Note: For the purposes of this Table, construction is NAICS 23; non-manufactured materials is 111CA, 113FF, 211, 212, and 213; wholesale and retail trade is 42 and44RT; utilities is 22,513 , and 562; professional services is 514, 521CI, 523, 524, 525, 531, 532RL, 5411, 5415, 5412OP, 55, 561, 61, 621, and 622HO; transportation and warehousing is 481, 482, 483, 484, 485, 486, 487OS, and 493; and other includes 511, 512, 624, 711 AS, 713, 721, 722, 81, and government entities

Note: The green bars represent a visual comparison within each subsector (e.g., wood products) between categories (e.g., construction). Higher values have longer bars (e.g., the wood products sector uses more professional services than any other category; therefore, it has the longest green bar). 
Table 4.4: Manufacturing Products Used by Other Industries (\$million 2009)

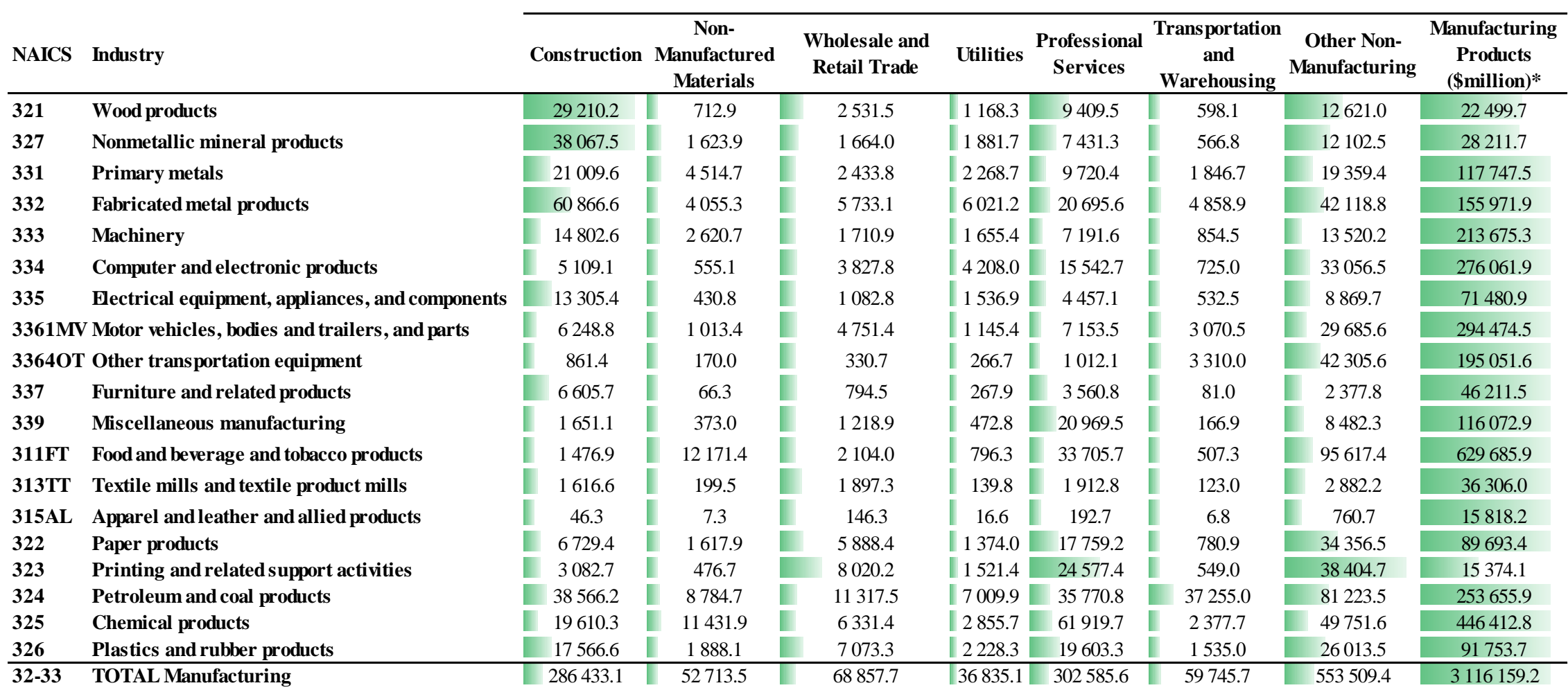

Note: For the purposes of this Table, construction is NAICS 23; non-manufactured materials is 111CA, 113FF, 211, 212, and 213; wholesale and retail trade is 42 and44RT; utilities is 22, 513, and 562; professional services is 514, 521CI, 523, 524, 525, 531, 532RL, 5411, 5415, 5412OP, 55, 561, 61, 621, and 622HO; transportation and warehousing is 481, 482, 483, 484, 485, 486, 487OS, and 493; and other includes 511, 512, 624, 711AS, 713, 721, 722, 81, and government entities

Note: The green bars represent a visual comparison within each subsector (e.g., wood products) between categories (e.g., construction). Higher values have longer bars. 
Table 4.5: Manufacturing Industry Impact on Value Added, 2009

\begin{tabular}{|c|c|c|c|c|c|c|c|c|c|c|c|c|c|}
\hline & & $\mathbf{A}$ & $W$ & B & $x$ & $=\mathbf{A}+\mathbf{B}$ & $=W+X$ & $\mathbf{C}$ & $Y$ & D & $Z$ & $=A+B+C+D$ & $=W+X+Y+Z$ \\
\hline NAICS & Industry & $\begin{array}{l}\text { Product Used in } \\
\text { Non- } \\
\text { Manufacturing } \\
\text { Industries } \\
\text { (\$million) }\end{array}$ & $\begin{array}{c}\text { As a } \\
\text { Percent } \\
\text { of Total } \\
\text { Value } \\
\text { Added }\end{array}$ & $\begin{array}{c}\text { Product Used } \\
\text { in the } \\
\text { Manufacturing } \\
\text { Industry } \\
\text { (\$millions)* }\end{array}$ & $\begin{array}{c}\text { As a } \\
\text { Percent } \\
\text { of Total } \\
\text { Value } \\
\text { Added }\end{array}$ & $\begin{array}{l}\text { Total Industry } \\
\text { Value Added } \\
\text { (\$millions) }\end{array}$ & $\begin{array}{c}\text { Asa } \\
\text { Percent } \\
\text { of Total } \\
\text { Value } \\
\text { Added }\end{array}$ & $\begin{array}{c}\text { Non- } \\
\text { Manufacturing } \\
\text { Products Used } \\
\text { (\$million) }\end{array}$ & $\begin{array}{c}\text { As a } \\
\text { Percent } \\
\text { ofTotal } \\
\text { Value } \\
\text { Added }\end{array}$ & $\begin{array}{c}\text { Manufacturing } \\
\text { Products Used } \\
\text { (\$million)** }\end{array}$ & $\begin{array}{c}\text { As a } \\
\text { Percent } \\
\text { of Total } \\
\text { Value } \\
\text { Added }\end{array}$ & $\begin{array}{c}\text { Total } \\
\text { Impact on } \\
\text { Value } \\
\text { Added } \\
\text { (\$million) }\end{array}$ & $\begin{array}{c}\text { As a Percent } \\
\text { of Total } \\
\text { Value Added }\end{array}$ \\
\hline 321 & Wood products & 14581 & $0.10 \%$ & 5832 & $0.04 \%$ & 20413 & $0.14 \%$ & 3661 & $0.03 \%$ & 594 & $0.00 \%$ & 24668 & $0.17 \%$ \\
\hline 327 & Nonmetallic mineral products & 25771 & $0.18 \%$ & 11479 & $0.08 \%$ & 37250 & $0.26 \%$ & 5303 & $0.04 \%$ & 965 & $0.01 \%$ & 43517 & $0.31 \%$ \\
\hline 331 & Primary metals & 14522 & $0.10 \%$ & 27961 & $0.20 \%$ & 42483 & $0.30 \%$ & 5618 & $0.04 \%$ & 1264 & $0.01 \%$ & 49365 & $0.35 \%$ \\
\hline 332 & Fabricated metal products & 56910 & $0.40 \%$ & 61493 & $0.44 \%$ & 118403 & $0.84 \%$ & 13646 & $0.10 \%$ & 4872 & $0.03 \%$ & 136921 & $0.97 \%$ \\
\hline 333 & Machinery & 17685 & $0.13 \%$ & 89217 & $0.63 \%$ & 106902 & $0.76 \%$ & 52410 & $0.37 \%$ & 30103 & $0.21 \%$ & 189415 & $1.34 \%$ \\
\hline 334 & Computer and electronic products & 36187 & $0.26 \%$ & 158506 & $1.12 \%$ & 194693 & $1.38 \%$ & 53354 & $0.38 \%$ & 12125 & $0.09 \%$ & 260172 & $1.84 \%$ \\
\hline 335 & Hectrical equipment, appliances, and components & 14811 & $0.10 \%$ & 35039 & $0.25 \%$ & 49850 & $0.35 \%$ & 13408 & $0.09 \%$ & 7875 & $0.06 \%$ & 71132 & $0.50 \%$ \\
\hline 3361MV & Motor vehicles, bodies and trailers, and parts & 11747 & $0.08 \%$ & 65183 & $0.46 \%$ & 76930 & $0.54 \%$ & 66964 & $0.47 \%$ & 37541 & $0.27 \%$ & 181435 & $1.29 \%$ \\
\hline $33640 T$ & Other transportation equipment & 16966 & $0.12 \%$ & 68576 & $0.49 \%$ & 85542 & $0.61 \%$ & 51314 & $0.36 \%$ & 21174 & $0.15 \%$ & 158030 & $1.12 \%$ \\
\hline 337 & Furniture and related products & 5321 & $0.04 \%$ & 17878 & $0.13 \%$ & 23199 & $0.16 \%$ & 15246 & $0.11 \%$ & 6084 & $0.04 \%$ & 44528 & $0.32 \%$ \\
\hline 339 & Miscellaneous manufacturing & 17557 & $0.12 \%$ & 61135 & $0.43 \%$ & 78692 & $0.56 \%$ & 27994 & $0.20 \%$ & 12089 & $0.09 \%$ & 118775 & $0.84 \%$ \\
\hline 311FT & Food and beverage and tobacco products & 39048 & $0.28 \%$ & 167973 & $1.19 \%$ & 207021 & $1.47 \%$ & 235885 & $1.67 \%$ & 37652 & $0.27 \%$ & 480558 & $3.40 \%$ \\
\hline 313TT & Textile mills and textile product mills & 3303 & $0.02 \%$ & 13671 & $0.10 \%$ & 16974 & $0.12 \%$ & 6617 & $0.05 \%$ & 3678 & $0.03 \%$ & 27270 & $0.19 \%$ \\
\hline 315AL & Apparel and leather and allied products & 713 & $0.01 \%$ & 9587 & $0.07 \%$ & 10300 & $0.07 \%$ & 2752 & $0.02 \%$ & 1089 & $0.01 \%$ & 14140 & $0.10 \%$ \\
\hline 322 & Paper products & 24073 & $0.17 \%$ & 31519 & $0.22 \%$ & 55592 & $0.39 \%$ & 13323 & $0.09 \%$ & 3642 & $0.03 \%$ & 72557 & $0.51 \%$ \\
\hline 323 & Printing and related support activities & 27730 & $0.20 \%$ & 5563 & $0.04 \%$ & 33293 & $0.24 \%$ & 3119 & $0.02 \%$ & 959 & $0.01 \%$ & 37372 & $0.26 \%$ \\
\hline 324 & Petroleum and coal products & 54454 & $0.39 \%$ & 62805 & $0.44 \%$ & 117259 & $0.83 \%$ & 68769 & $0.49 \%$ & 3658 & $0.03 \%$ & 189686 & $1.34 \%$ \\
\hline 325 & Chemical products & 51712 & $0.37 \%$ & 149633 & $1.06 \%$ & 201345 & $1.43 \%$ & 100991 & $0.72 \%$ & 21659 & $0.15 \%$ & 323996 & $2.29 \%$ \\
\hline 326 & Plastics and rubber products & 24667 & $0.17 \%$ & 29817 & $0.21 \%$ & 54484 & $0.39 \%$ & 12154 & $0.09 \%$ & 7380 & $0.05 \%$ & 74019 & $0.52 \%$ \\
\hline $32-33$ & TOTAL Manufacturing & 457758 & $3.24 \%$ & 1072865 & $7.60 \%$ & 1530624 & $10.84 \%$ & 752528 & $5.33 \%$ & - & - & 2283152 & $16.17 \%$ \\
\hline
\end{tabular}


activity while the software publishing sector (NAICS 511200) produced $\$ 128380.1$ million. ${ }^{77}$

\subsection{Bureau of Labor Statistics: Labor and Productivity}

The Bureau of Labor Statistics (BLS), an agency within the Department of Labor, measures labor market activity, working conditions, and price changes in the economy. There are two measures provided by the BLS that measure productivity: labor productivity and multifactor productivity. Labor productivity relates output to labor hours used to produce output while multifactor productivity relates output to a combined set of inputs such as labor and capital. The BLS also tracks employment through two surveys: Current Employment Statistics (CES) program and the Current Population Survey (CPS). The CES surveys approximately 140000 businesses and government agencies to provide data on employment, hours, and earnings. The CPS is a monthly survey of households conducted by the Bureau of the Census. ${ }^{78}$

Productivity: Manufacturing labor productivity has increased significantly in recent decades. As seen in Figure 4.13, labor productivity in manufacturing increased $105.1 \%$ between 1987 and 2008 while private non-farm business increased $64.9 \%$; thus, manufacturing labor productivity is increasing faster than the whole of the U.S. economy. The industry with the largest productivity gains is the computer and electronics sector (NAICS 334) which increased $1009.3 \%$ (not shown), more than 10 times larger than any other manufacturing subsector shown in Figure 4.13. Between 1987 and 2009, multifactor productivity (not shown) increased $26.3 \%$ for all manufacturing and $661.2 \%$

Figure 4.13: Output per Unit of Labor (aggregate percent increase of BLS Index)

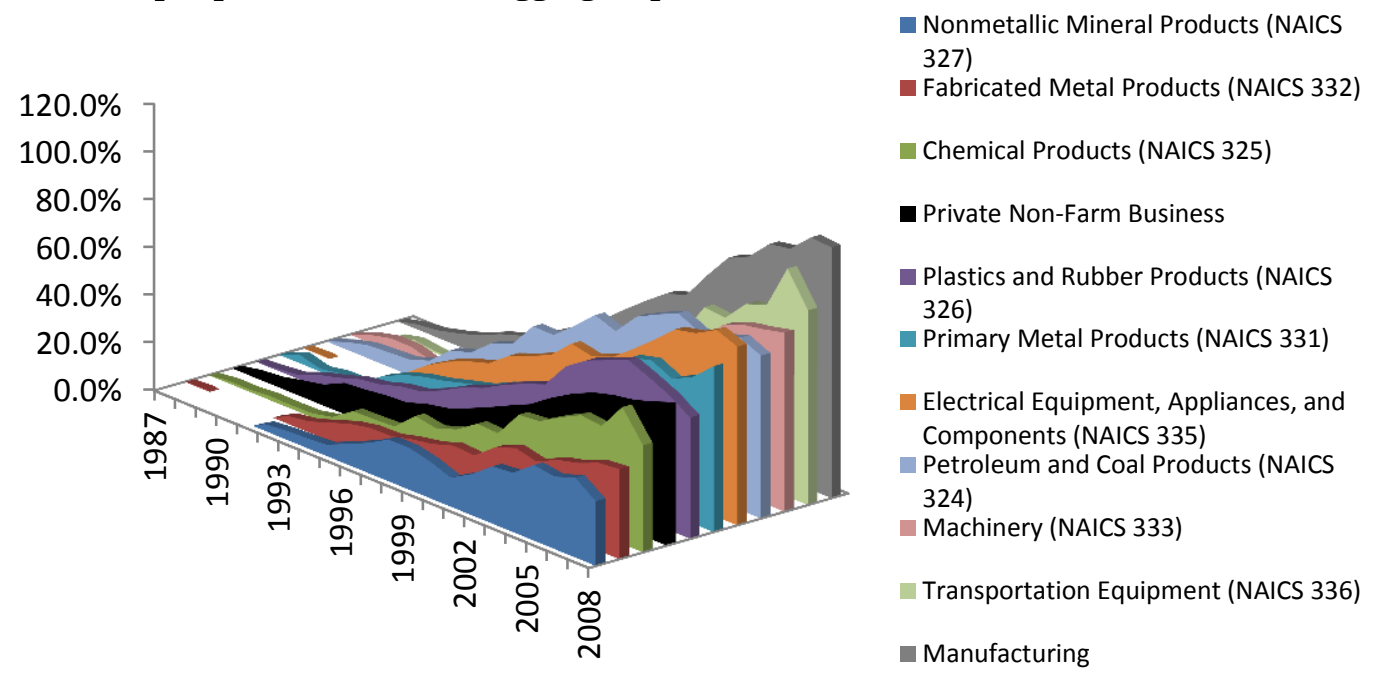

\footnotetext{
${ }^{77}$ Software publishing was estimated as the 2002 ratio of the value of software publishing industry output (NAICS 511200) to the value of the publishing industry output (NAICS 511) multiplied by the value of the publishing industry output for non-manufacturing industries in 2009.

${ }^{78}$ Bureau of Labor Statistics. "BLS Productivity Statistics." <http://www.bls.gov/bls/productivity.htm>
} 
for computer and electronic products. During the same period machinery (NAICS 333); electrical equipment, appliances, and components (NAICS 335); and transportation equipment (NAICS 336) declined 7.2\%, 18.2 \%, and $3.3 \%$ respectively. It is important to note that the source of productivity gains in manufacturing have been questioned somewhat. It has been suggested that the source of at least some of these gains are due to outsourcing. ${ }^{79}$

Employment: Employment levels for manufacturing have fluctuated somewhat in recent decades and have recently declined significantly. As seen in Figure 4.14, manufacturing as a percent of total non-farm employment has had a downward trend since 1919 with the exception of a period during World War II when the U.S. was manufacturing military supplies. According to NAICS CES data, 15.0 million workers were employed in manufacturing in 1961. Employment peaked in 1979 to 19.4 million and declined $41 \%$ to 11.5 million in 2010, as seen in Figure 4.15. Many of the subsectors shown in the figure trend upwards until some point between the mid-70's and mid-80's where they plateau somewhat or trend downwards. According to CPS data, there were 14.1 million employed persons in the manufacturing industry in 2010 . Of these, $97 \%$ is private industry workers, $2 \%$ is self employed, and less than one percent is government and unpaid family workers. The 2010 estimate of the number of employees is down $17 \%$ from 16.9 million in 2003.

Wages: Wages in the U.S. manufacturing industry had a general upward trend from 1919 until the early 70's where they began to plateau or even trend downwards, as seen in Figure 4.16. This trend however, is similar to the trend for the wages for all those in

\section{Figure 4.14: Manufacturing Employment as a Percent of Total Non-Farm Employment (CES)}

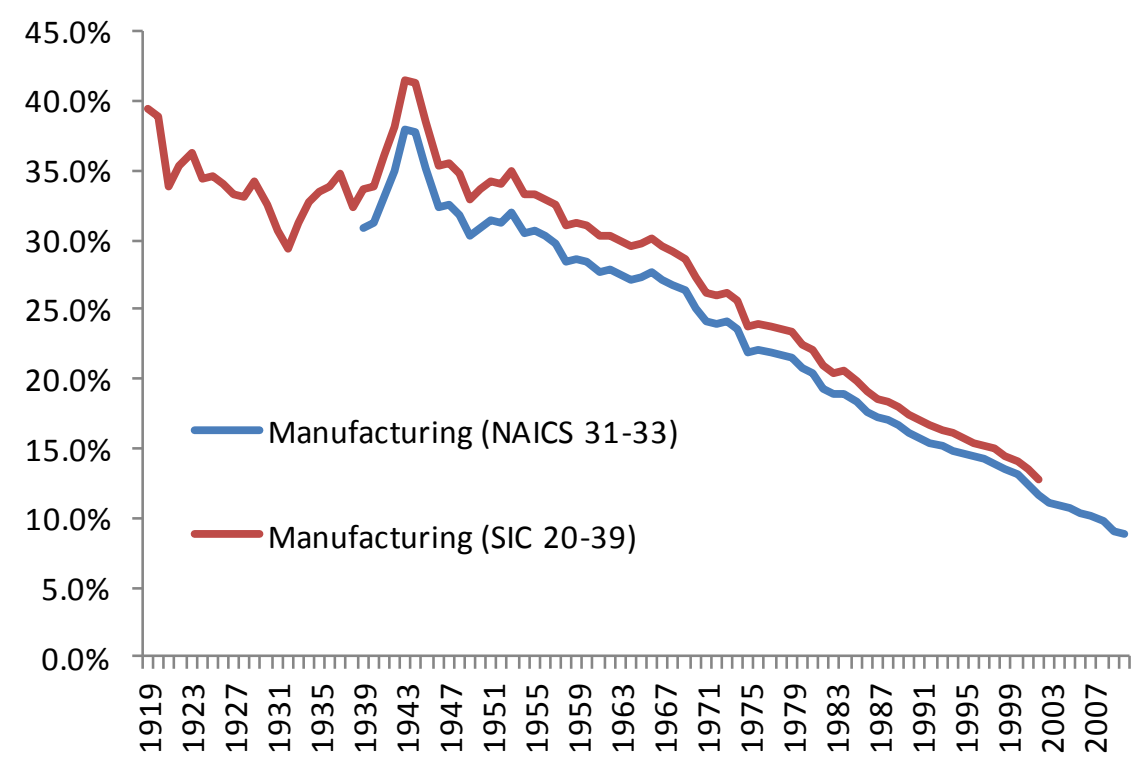

\footnotetext{
${ }^{79}$ Houseman, Susan. "Outsourcing, Offshoring, and Productivity Measurement in U.S. Manufacturing." Upjohn Institute Staff Working Paper No. 06-130. June 2006.

<http://www.upjohninst.org/publications/wp/06-130.pdf>
} 
Figure 4.15: Employment in Manufacturing and Select Subsectors, 1919-2010 (Current Employment Survey)

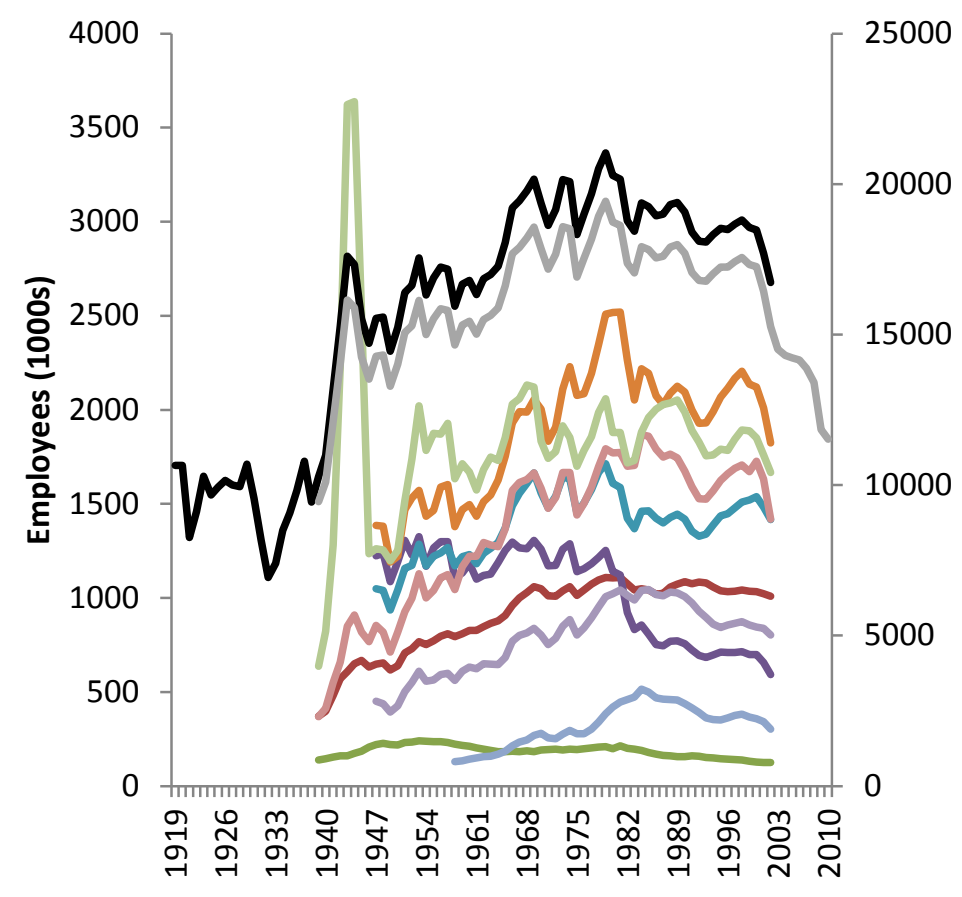

Chemicals and allied products (SIC 28)

Petroleum and coal products (SIC 29)

Primary metal Industries (SIC 33)

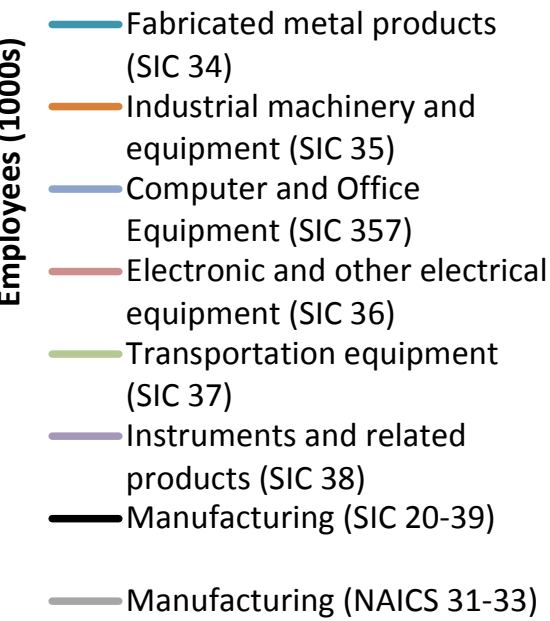

Figure 4.16: Wages in Manufacturing and Select Subsectors, 1919-2010 (Current Employment Statistics)

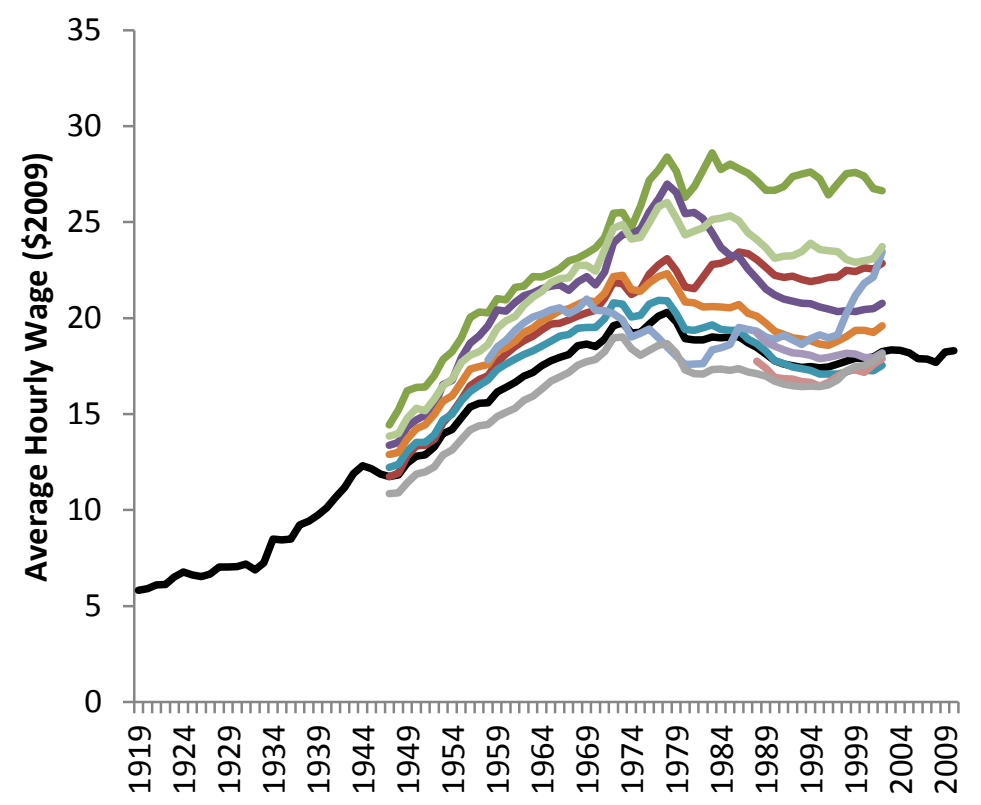

Manufacturing (SIC 20-39)*

Chemicals and allied products (SIC 28)

Petroleum and coal products (SIC 29)

Primary metal Industries (SIC 33)

Fabricated metal products (SIC 34)

Industrial machinery and equipment (SIC 35)

Computer and Office Equipment (SIC 357)

Electronic and other electrical equipment (SIC 36)

Transportation equipment (SIC 37)

Instruments and related products (SIC 38)

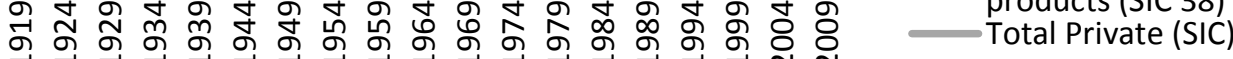

* 2003 to 2010 is NAICS $31-33$ 
private industry. The average hourly earnings for all private workers using the NAICS format from the CES was \$22.21 in 2009 while it was \$23.04 for manufacturing workers.

\subsection{National Science Foundation: Research and Development}

The National Science Foundation (NSF) is an independent federal agency created by Congress in 1950. As stated by the NSF, it was created "to promote the progress of science; to advance the national health, prosperity, and welfare; [and] to secure the national defense..." The agency collects data on research and development expenditures and provides them through its National Center for Science and Engineering Statistics (NCSES) ${ }^{80}$ The data is broken into categories by funding sources, industry, and by type of research. Since federally funded research represents less than $10 \%$ of total funding, this report will focus on non-federally funded expenditures, which reflects trends in the private industry. Total federal research funding, however, is briefly discussed. It is important to note that the funds for research and development discussed in this section, including federal funds, is activity performed within company owned or company operated facilities.

As mentioned previously, significant concern has been expressed in regards to U.S. research and development expenditures compared to those abroad. This concern is primarily in regards to its proportion of global research and development expenditures $;{ }^{81}$ however, a decline of the proportion of these activities is not unexpected and is not by itself considered a decline in the U.S. manufacturing industry. A greater concern is its nominal and real performance relative to its population and/or resources. It is in this context that this report examines research and development.

Research and development expenditures in the manufacturing industry accounted for $69.5 \%$ of the total for the U.S. Expenditures have increased significantly for the chemical industry as seen in Figure 4.17. Between 2000 and 2006 it increased $89.7 \%$. Pharmaceuticals and medicines, which increased $159.2 \%$ during the same period (see Figure 4.18), represented 84.2\% of chemical research in 2006. During the 2000 to 2006 period, computer and electronic product research expenditures decreased $7.4 \%$; however, a number of this industry's subsectors increased significantly: semiconductor and other electronic component research was up $23.8 \%$, computers and peripheral equipment were up $20.6 \%$, and other computer and electronic products were up $199.0 \%$ (see Figure 4.18). As illustrated in Figure 4.17, machinery and transportation equipment research increased $27.3 \%$ and $11.9 \%$ respectively.

Approximately $39 \%$ of total research and development expenditures in 1953 were funded by the Federal government with the remainder being from company and other sources, as illustrated in Figure 4.19. This percentage did not drop below $30 \%$ until 1989 where it began a downward trend until 2002 where it represented 8.5\%. Between 2002 and 2007 it increased to $9.9 \%$. Overall, total expenditures have had a general upward

\footnotetext{
${ }^{80}$ National Science Foundation. "Business and Industrial R\&D." < http://www.nsf.gov/statistics/industry/>

${ }^{81}$ Tassey Gregory. "Rationales and Mechanisms for Revitalizing U.S. Manufacturing R\&D Strategies." Journal of Technology Transfer. 35 (2010): 283-333.
} 
trend between 1953 and 2007 with the exception of a few years. Approximately $4 \%$ of nonfederal research expenditures was basic research, $20 \%$ applied, and $76 \%$ was development in 2007. This has changed only slightly since 1953 where it was $6 \%, 20 \%$, and $74 \%$ respectively. Federal funding for defense related research and development represented $16.2 \%$ of total 2007 research and development (not shown). Space, civilian, and nonfederal related expenditures are $1.4 \%, 9.3 \%$, and $73.9 \%$ respectively (not shown).

Figure 4.17: Company and Other Research and Development by Industry

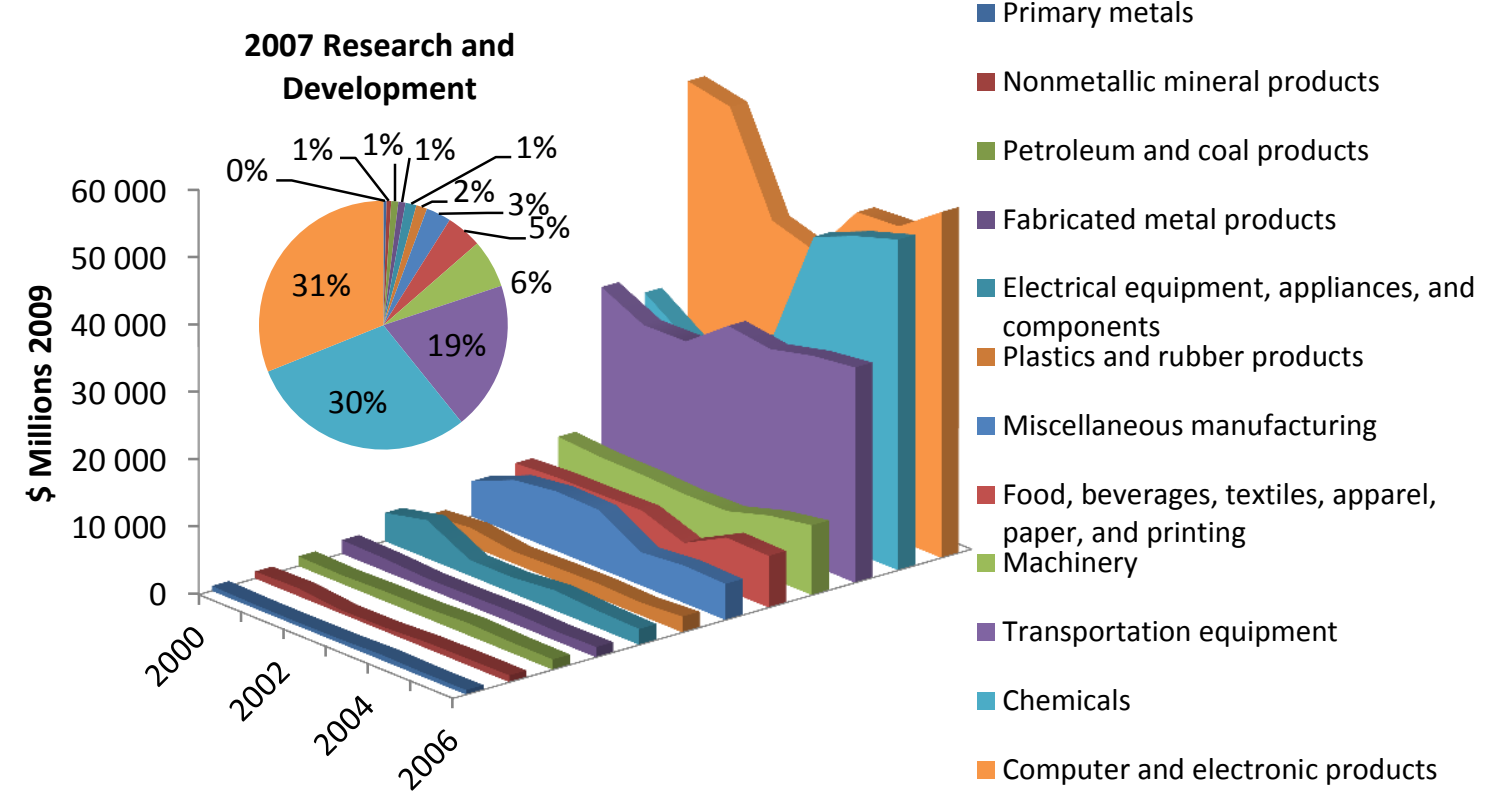


Figure 4.18: Company and Other Research and Development by Industry (subsectors of the chemical industry and computer and electronic industry)

- Other computer and electronic products

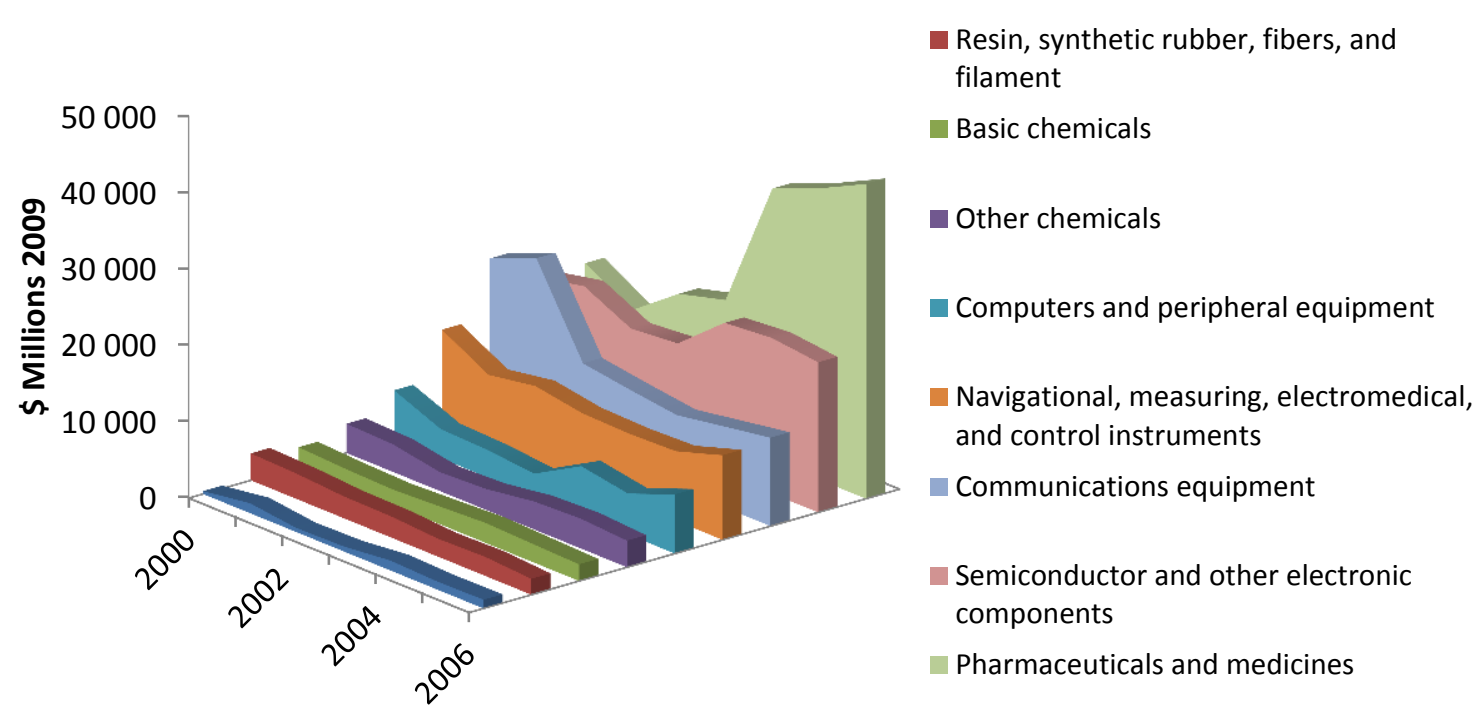

NOTE: Adjusted using the CPI

Figure 4.19: Research and Development by Source of Funds

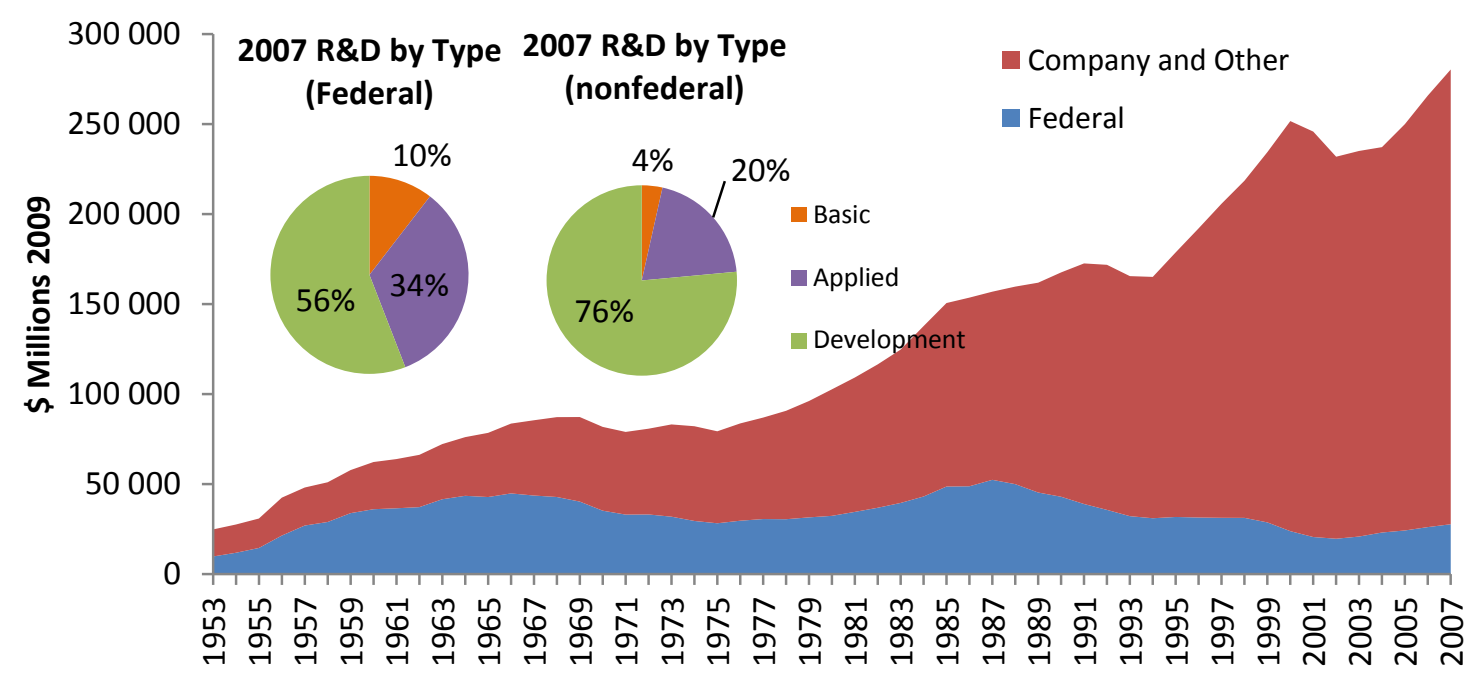




\section{Characterizing the U.S. Manufacturing Industry}

\subsection{Production}

According to UNSD data, U.S. manufacturing growth lags behind that of many countries and is growing slower than the whole of the U.S. economy. Compound annual growth is below the $20^{\text {th }}$ percentile of 180 nations. While manufacturing value added is larger in the U.S. than in any other country, U.S. manufacturing per capita has lagged slightly behind some industrialized nations, such as Germany and Japan. Out of 199 countries, at least 20 other nations have a higher manufacturing value added per capita than the U.S. in 2008, according to UNSD data. Manufacturing as a percent of total Gross Domestic Product (GDP) has declined in the U.S. as it has declined in many industrialized nations.

Among all OECD countries for which data is available in 2009, the U.S. ranks above the $70^{\text {th }}$ percentile in value added per capita (see Table 3.4) in food, apparel, wood product, and printing; refined petroleum products and nuclear fuel; chemicals; office, accounting, and computing machinery; radio, television and communications equipment; medical, precision, and optical instruments; transport equipment; and other manufacturing. That is, in per capita terms the U.S. produces more than at least $70 \%$ of those ranked. Among those OECD countries for which data is available, the U.S. is above the $70^{\text {th }}$ percentile in terms of the gross operating surplus per expenditure dollar for at least four sectors of manufacturing in 2009: refined petroleum products and nuclear fuel; chemicals; machinery and equipment; electrical machinery and apparatus; and total manufacturing. Manufacturing's share of employment has declined for all OECD countries including the U.S.

According to OECD input-output data for 39 countries, the U.S. has the largest value added in the mid-2000's for all manufacturing subsectors except basic metals; office, accounting, and computing machinery; and electrical machinery and apparatus as seen in the rankings in Table 3.9. In terms of value added per capita, the U.S. ranks $4^{\text {th }}$ in office, accounting, and computing machinery, $11^{\text {th }}$ for all manufacturing, and does not rank first for any subsector in terms of value added per capita. According to these data, the whole of the U.S. manufacturing industry impacts $\$ 6446$ billion or $27.9 \%$ of total output (see Table 3.11), slightly more than is estimated using BEA data. This percentage is lower than other countries such as China, Germany, India, and Japan which have impacts of $62.1 \%, 44.9 \%, 45.3 \%$, and $41.2 \%$ respectively.

In 2009, the total value of shipments in manufacturing was $\$ 4.44$ trillion, according to the ASM. Value added for all manufacturing was $\$ 1978.2$ billion in 2009. Approximately $9.8 \%$ of this value is computer and electronic product manufacturing as illustrated in Table 4.1. This sector increased $15.5 \%$ from $\$ 214.3$ billion in 1997 to $\$ 247.6$ billion in 2000 . During the early 2000's recession it declined to a low of $\$ 182.9$ billion in 2002 , but increased until the late 2000's recession as illustrated in Figure 4.1. Semiconductor and other electronic components manufacturing (NAICS 3344) is $3.0 \%$ of the manufacturing industry and has a net income per expenditure dollar ratio of 0.173. During the 1997 to 
2009 period, employment declined for all sectors shown in Figure 4.1: petroleum and coal products declined $6 \%$; chemicals $18 \%$; plastics and rubber $34 \%$; nonmetallic mineral products $28 \%$; primary metals $41 \%$; fabricated metal $26 \%$; machinery $32 \%$; computer and electronic products $46 \%$; electrical equipment, appliance, and components $41 \%$; and transportation $33 \%$. Each subsector's proportion of employment and value added is shown in Figure 4.3. The net income for all manufacturing in 2009 was $\$ 659.9$ billion.

The Manufacturer's Shipments, Inventories, and Orders Survey indicates that computer and electronic product manufacturing represents $8 \%$ of manufacturing shipments down from $10 \%$ in 1992. This decline is likely due to changes in the price of computer and electronic product manufacturing and not due to a decline in the volume of physical production. This industry grew by $47 \%$ between 1992 and 2009, faster than any other industry shown in Figure 4.7.

BEA GDP by industry shows manufacturing as $8 \%$ of U.S. growth between 1947 and 2009 while the largest growth sector was the finance, insurance, real estate, rental, and leasing sector with real estate representing the majority of this growth. GDP grew $501 \%$ between 1947 and 2009 while manufacturing grew $164 \%$. The slower growth in manufacturing has resulted in a downward trend in manufacturing's share of GDP. This trend seems to pervade as far back as 1947 when data was first collected. This sentiment is supported by manufacturing's share of total employment, which also has a pervading downward trend with the exception of the World War II era (see Figure 4.14). As seen in Table 4.2, the total impact of computer and electronic product manufacturing is $\$ 457.9$ billion or $1.9 \%$ of total output. Food, beverage, and tobacco products is the largest with $\$ 1319.7$ billion or $5.3 \%$ of total output. Chemical products is the second largest and petroleum and coal products is the third largest. Other industries such as machinery; electrical equipment, appliances, and components; motor vehicles, bodies, trailers, and parts; and other transportation represented $1.7 \%, 0.6 \%, 2.3 \%$, and $1.5 \%$ respectively. Manufacturing's total impact on output is $\$ 5705.2$ billion or $23 \%$ of total output.

Manufacturing labor productivity has increased significantly in recent decades, as indicated by BLS data. As seen in Figure 4.13, labor productivity in manufacturing increased $105.1 \%$ between 1987 and 2008 while private non-farm business increased $64.9 \%$; thus, manufacturing labor productivity is increasing faster than the whole of the U.S. economy. Employment levels for manufacturing have fluctuated somewhat in recent decades and have recently declined significantly. According to CES data, 15.0 million workers were employed in manufacturing in 1961. Employment peaked in 1979 to 19.4 million and declined $41 \%$ to 11.5 million in 2010. Wages in the U.S. manufacturing industry had a general upward trend from 1919 until the early 70's where they began to plateau or even trend downwards, as seen in Figure 4.16.

\subsection{Research, Development, and Technology}

Among all OECD countries for which data is available, the U.S. ranks above the 85th percentile during the 2001 to 2008 period for total research and development 
expenditures for all subsectors, as seen in Table 3.13. From 2001 through 2007, it was above the 90th percentile for all subsectors of manufacturing and above the $95^{\text {th }}$ percentile for total manufacturing. In terms of per capita research and development expenditures, 2007 U.S. values rank above the 70th percentile for a number of subsectors and total manufacturing (see Table 3.14). According to OECD patent data, as seen in Table 3.15, between 1999 and 2007 the U.S. has ranked above the $90^{\text {th }}$ percentile in terms of total number of patents and above the $80^{\text {th }}$ percentile in terms of patents per capita. During that same period, U.S. patents represented between $30 \%$ and $41 \%$ of total patents worldwide.

As indicated by World Bank data, the U.S. ranks above the $90^{\text {th }}$ percentile for 2009 patent applications (resident and nonresident), patent applications per capita (resident and nonresident), and royalty license fees (payments and receipts). Researchers per million people were above the $85^{\text {th }}$ percentile in 2006 , the latest data available. Scientific and technical journal articles authored by U.S. residents were above the $95^{\text {th }}$ percentile and articles per capita were above the $90^{\text {th }}$ percentile in 2007 , the latest available data. Research and development expenditures as a percent of GDP was above the $85^{\text {th }}$ percentile in 2008 and above the $90^{\text {th }}$ percentile in 2007. The Global Competitiveness Index ranked the U.S. as $4^{\text {th }}$ in innovation and $17^{\text {th }}$ in technological readiness among 139 countries. The IMD World Competitiveness Yearbook ranks the U.S. as $1^{\text {st }}$ for scientific infrastructure and $2^{\text {nd }}$ for technological infrastructure out of 59 countries. The 2003 Competitive Industrial Performance Index puts the U.S. above the $90^{\text {th }}$ percentile for its share of medium- and high-tech value added as a percent of total manufacturing value added; however, it puts the U.S. just above the $55^{\text {th }}$ percentile for its share of manufacturing value added as a percent of total GDP (see Table 3.17).

Between 1953 and 2007 total research and development expenditures has increased $1031 \%$, according to NSF data; however, during the 2000 to 2007 period it only increased $11 \%$. During the 2000 to 2006 period, computer and electronic product research expenditures decreased $7.4 \%$; however, a number of this industry's subsectors increased significantly: semiconductor and other electronic component research was up $23.8 \%$, computers and peripheral equipment were up $20.6 \%$, and other computer and electronic products were up $199.0 \%$ (see Figure 4.18). As illustrated in Figure 4.17, machinery and transportation equipment research increased $27.3 \%$ and $11.9 \%$ respectively. Overall, total expenditures have had a general upward trend between 1953 and 2007 with the exception of a few years.

\subsection{Stakeholder's Perspective}

Owners and Finance Services: The owners of U.S. manufacturing firms invest land, capital goods, and financial capital with the expectation of receiving a profit from the sales of manufactured goods. The primary variable available to examine and compare the returns for owners and financiers internationally is gross operating surplus per dollar of expenditure. Gross operating surplus is gross output less a subset of costs (i.e., intermediate expenditures, compensation, and taxes less subsidies) and does not take into account the depreciation of capital; therefore, it does not fully represent a return on 
investment. However, it is the best variable available. OECD data for 2004 through 2009 put the U.S. manufacturing industry as a whole above the $75^{\text {th }}$ percentile for gross operating surplus per dollar of expenditure (see Table 3.5). This data also shows that the 2005 U.S. employer enterprise birth rate (number of new enterprises divided by the number of existing enterprises) is less than the death rate; thus, more businesses were eliminated from manufacturing than were created (see Table 3.8). According to OECD input-output data for the mid-2000's, the U.S. ranks $14^{\text {th }}$ out of 39 countries or just above the $60^{\text {th }}$ percentile in terms of gross operating surplus per dollar of expenditure. The office, accounting and computing machinery subsector ranked $9^{\text {th }}$ or just above the $75^{\text {th }}$ percentile.

The Annual Survey of Manufactures provides an opportunity to examine the net income (also known as net profit or simply profit) of the U.S. manufacturing industry. Net income is different from gross operating surplus in that it accounts for depreciation of assets or capital. In 2009, the total net income from the manufacturing industry in 2009 was $\$ 659.9$ billion. Approximately $32.3 \%$ of the net income was from the production of food, beverages, textiles, apparel, paper, and printing (NAICS 311-323). Another $27.5 \%$ is from chemical manufacturing while computer and electronic product manufacturing represented $7.8 \%$ as calculated from the data in Table 4.1. Net income represented $14.9 \%$ of the total value of shipments. The net income per expenditure dollar was 0.18 for the whole of manufacturing while computer and electronic product manufacturing was slightly higher at 0.19 . Stated another way, the return on investment for manufacturing is $18 \%$ while computer and electronic product manufacturing was $19 \%$. Even with the highest costs for materials, buildings, and machinery, the return on investment for semiconductor and other electronic component manufacturing was $17 \%$ (see Appendix C).

Employees: Employees exchange their time for compensation or income. The manufacturing industry employed 12.5 million people or $4.2 \%$ of the population in the U.S. according to 2006 UNIDO data. Canada, China, Germany, India, Japan, Mexico, and the UK employ 1.9 million (6\%), 72.3 million (6\%), 6.9 million (8.4\%), 8.8 million $(0.8 \%), 7.5$ million $(5.9 \%), 4.3$ million $(4.0 \%)$, and 3.1 million $(5.2 \%)$ respectively. In the U.S., approximately 101 thousand employees work in the office, accounting, and computing machinery sector. The wages for manufacturing workers is $\$ 47.2$ thousand annually in the U.S. while Canada, China, Germany, India, Japan, Mexico, and the UK are $\$ 30.8$ thousand, $\$ 2.9$ thousand, $\$ 47.7$ thousand, $\$ 1.8$ thousand, $\$ 30.5$ thousand, $\$ 4.8$ thousand, and $\$ 41.9$ thousand respectively. OECD STAN data puts U.S. manufacturing wages above the $90^{\text {th }}$ percentile between 2001 and 2008 with its subsectors mostly ranking above the $80^{\text {th }}$ percentile. Manufacturing's share of total employment has declined in the U.S. as it has for many nations.

According to the Annual Survey of Manufactures there were 11.1 million manufacturing employees in 2009 with 908 thousand or $8 \%$ being in the computer and electronic product manufacturing sector. The average compensation for the industry as a whole was $\$ 62.9$ thousand annually with the computer and electronic product sector being 
$\$ 84.5$ thousand. The 294 thousand individuals working in the semiconductor and related device sector made $\$ 71.9$ thousand annually.

Resellers, Transportation and Warehousing, Industry Suppliers, and Professional Services: Companies and organizations provide products and services to the manufacturing industry in exchange for compensation that results in a profit. Tracking these profits is difficult since there does not exist readily available data on the profit gained through domestic manufacturing alone; therefore, this report has largely focused on the purchases of non-manufacturing products and services rather than the profit gained from the purchases. According to OECD input-output data, electronics manufacturing (ISIC 30-32), machinery manufacturing (ISIC 29, 33-35), and other manufacturing (ISIC $15-28,36-37$ ) used $\$ 115$ billion, $\$ 393$ billion, and $\$ 1000$ billion of non-manufactured products and services for a total of $\$ 1508$ billion or $6.5 \%$ of total output. The total impact of the manufacturing industry is $\$ 6446$ billion or $27.9 \%$ of output. The total impact of the manufacturing industry in other nations such as Australia, Canada, China, Germany, India, Japan, Mexico and the UK is $24.7 \%, 33.8 \%, 62.1 \%, 44.9 \%, 45.3 \%$, $41.2 \%, 41.8 \%$, and $24.8 \%$ of total output respectively.

According to BEA data, the manufacturing industry uses $\$ 1228$ billion of nonmanufactured goods and services and impacts $23.0 \%$ of total output or $\$ 5705$ billion. Computer and electronic products impacts $1.9 \%$ of output. The whole of the manufacturing industry uses $\$ 22.3$ billion of construction products, $\$ 264.7$ billion of nonmanufactured materials, $\$ 171.4$ billion of wholesale and retail trade, $\$ 87.0$ billion of utilities, $\$ 500.4$ billion of professional services, $\$ 94.4$ billion of transportation and warehousing, and $\$ 88.2$ billion of other non-manufactured products and services.

Consumers: Data on the utility that consumers gain by purchasing domestically produced manufacturing products is not readily available. Additional research is needed to gain further knowledge in this area.

Standards and Codes Organizations, Public Vested Interests, and Professional Societies: There are many organizations and individuals that have interests in the economic success of the manufacturing industry. This interest hinges on the primary stakeholders (owners, finance services, and employees), the technology produced, as well as the size of the industry. The primary stakeholders were discussed above in both the terms of domestic and international data. Assessing the technology produced by the industry must be measured in an indirect manner using research and development expenditure data, patent data, and journal publication data as there is not a direct measurement available. According to OECD STAN data, 2006 research and development expenditures in the U.S. amounted to $\$ 172.7$ billion with $\$ 1.5$ billion being in office, accounting, and computing machinery. The U.S. expenditure is often above the $90^{\text {th }}$ percentile while expenditure per capita is commonly above the $80^{\text {th }}$ percentile.

Using the OECD Patent Database for 1999 through 2007, the U.S. accounts for more than $30 \%$ of the total number of patents registered while ranking above the $90^{\text {th }}$ percentile in the number of patents and above the $80^{\text {th }}$ percentile in the number of patents per capita. 
Using World Bank data for 2000 through 2009, the U.S. ranks above the $90^{\text {th }}$ percentile in the number of patent applications per capita for residents and above the $80^{\text {th }}$ percentile for nonresidents. Research and development expenditures as a percent of GDP ranks above the $90^{\text {th }}$ percentile with the exception of 2008. In terms of the number of researchers per million people, the U.S. ranks above the $90^{\text {th }}$ percentile between 2000 and 2004 and above the $85^{\text {th }}$ percentile in 2005 and 2006. In terms of the number of scientific and technical journal articles published per capita, the U.S. ranks above the $90^{\text {th }}$ percentile.

According to 2007 National Science Foundation data on research and development funded by companies, $31 \%$ of expenditures are in computer and electronic products, $30 \%$ in chemicals, and $19 \%$ in transportation. A large percentage of the computer and electronic research is in semiconductor and other electronic components. Approximately $76 \%$ of total nonfederal research is in development, $20 \%$ in applied research, and $4 \%$ in basic research.

Three international comparative indices were discussed that ranked national competitiveness: (1) UNIDO's Competitive Industrial Performance Index; (2) the World Economic Forum's Global Competitiveness Report; and (3) the IMD World Competitiveness Center's World Competitiveness Yearbook. These indices do not specifically address the manufacturing industry, but provide an overall comparison of economic activity. Among 121 nations, the Competitive Industrial performance Index ranked the U.S. as $9^{\text {th }}, 10^{\text {th }}$, and $12^{\text {th }}$ in 1993,1998 , and 2003. The Global Competitiveness Report ranked the U.S. as $4^{\text {th }}$ in $2010-2011,2^{\text {nd }}$ in $2009-2010$, and $1^{\text {st }}$ in 2008-2009. The World Competitiveness Yearbook ranked the U.S. as $1^{\text {st }}$ out of 59 countries in 2011.

\subsection{Characteristics of the U.S. Manufacturing Industry}

As seen in the manufacturing supply chain in Figure 4.5, there are many suppliers of goods and services that also have a stake in the industry; these include resellers, providers of transportation and warehousing, raw material suppliers, suppliers of intermediate goods, and suppliers of professional services. The manufacturing industry shipped $\$ 4436.2$ billion of goods in 2009 according to the industry supply chain in Figure 4.5. The value of communications; computer hardware, software, and other equipment; professional, technical, and data services; and other items used by the industry were $\$ 5.2$ billion, $\$ 12.0$ billion, and $\$ 29.3$ billion, and $\$ 254.9$ billion, respectively. These items, represented in blue in the supply chain, represent $6.8 \%$ of the total value of manufacturing shipments. Capital expenditures on buildings and structures $(\$ 43.3$ billion), machinery and equipment ( $\$ 110.9$ billion), and maintenance and repair were $4.3 \%$. Compensation ( $\$ 695.6$ billion) was $15.7 \%$ while materials and energy (shown in green in the supply chain) were $55.0 \%$. The expenditures just mentioned, account for $82.0 \%$ of total shipments, net income accounted for $14.9 \%$, and net inventories and depreciation accounted for $3.1 \%$. 


\section{Discussion and Research Needs}

\subsection{Discussion}

There are many theories that speculate the future of the U.S. manufacturing industry. These theories must take into account and be consistent with the data available on the industry. Frequently, anecdotal observations are used to depict the industry; however, the insight from these types of observations is limited, as the manufacturing industry includes hundreds of thousands of establishments with millions of employees making trillions of dollars worth of goods. Additionally, national economies are often compared to companies competing for market share; unfortunately, this is somewhat misleading. This report brings together data on the current state of the U.S. manufacturing industry as it relates to its stakeholders and, to the extent possible, compares this data internationally to develop a quantitative depiction of the industry. This provides a structured approach to characterizing the industry and its subsectors.

There is a general concern that the U.S. manufacturing industry has lost competitiveness with Asian manufacturing, particularly China. With over 1.3 billion people (more than the combined 2009 population of the U.S., Canada, Australia, Japan, and the whole of Europe), the Chinese economy has the potential to far exceed the size of the U.S. economy. However, China's rise is recent, rapid, and has come with some costs. Many of the policies and activities to attract manufacturing have short term gains for long term losses. Air and water pollution are becoming a significant concern ${ }^{82}$ as is waste disposal, which is inadequate as significant amounts of China's waste ends up in unlicensed dumps in the countryside. ${ }^{83}$ A looming housing bubble, harsh conditions for some workers, low wages, gender imbalance in the population, and remnants of a command economy may pose challenges to China's social and economic future. ${ }^{84,85,86}$ Thus, the sustainability of China's current economic situation is unknown and may face the prospects of a slowdown in growth as many emerging economies have experienced ${ }^{87,88}$ Therefore, it is also important to bear in mind that U.S. economic concerns regarding China are not unique. The U.S. has had similar concerns regarding Japan, Mexico, Thailand, and India. ${ }^{89}$ It is important to examine U.S. manufacturing in a way that considers the entirety of the industry and its subsectors while considering the various aspects of the industry.

\footnotetext{
${ }^{82}$ BBC. "China Pollution 'Threatens Growth'.” February 28, 2011.<http://www.bbc.co.uk/news/worldasia-pacific-12595872>

${ }^{83}$ CBS News. “As Economy Grows, So Do China's Garbage Woes.” October 11, 2009.

<http://www.cbsnews.com/stories/2009/10/11/ap/asia/main5377158.shtml>

${ }^{84}$ Davis, Bob. "The Great Property Bubble of China May be Popping." June 9, 2011. <http://online.wsj.com/article/SB10001424052702304906004576367121835831168.html>

${ }^{85}$ Shepherd, Robert J. "The People's Dynasty: Culture and Society in Modern China." Modern Scholar. Lecture Series. 2010.

${ }^{86}$ Harney, Alexandra. The China Price. (London, England: The Penguin Press, 2008).

${ }^{87}$ Economist. "Converging Economies: One-Track Bind." September 24, 2011. <http://www.economist.com/node/21528985>

${ }^{88}$ Zhang, Kevin Honglin. "Is China the World Factory." In China as the World Factory. (New York: Routeledge, 2006).

${ }^{89}$ Harney, Alexandra. The China Price. (London, England: The Penguin Press, 2008).
} 
China's manufacturing industry is rapidly approaching the size of the U.S. manufacturing industry; however, China's industry is far smaller than the U.S. industry on a per capita basis.

All this is not to say that the U.S. manufacturing industry does not have deficiencies, but the U.S. produced more manufactured goods per capita than $92.6 \%$ of OECD reporting countries in 2007 and produced more than any other country in the world. Industry growth, however, has been somewhat stagnant in the U.S. when compared internationally. UNSD data suggests that U.S. manufacturing growth is below the $20^{\text {th }}$ percentile of 180 countries. Manufacturing as a percent of GDP has declined in the U.S.; however, this percentage has declined globally. As demonstrated in this report, there are many aspects involved in tracking the current state and recent trends in the U.S. manufacturing industry and no single metric provides an accurate depiction.

\subsection{Recommendations for Further Research}

Tracking manufacturing activity provides significant challenges. For example, the components of one product may be produced in several different countries; the iPod is one example. Between the design and production of the iPod there are a number of countries involved: England, Germany, France, Italy, Japan, Korea, and the United States. ${ }^{90}$ Further research is needed to understand the role the U.S. has in developing and manufacturing intermediate and finished parts.

This report has focused on the trends and current state of the U.S. manufacturing industry and, therefore, largely excludes the environment in which the manufacturing industry operates. This includes taxes, regulations, infrastructure, the labor market, and current economic conditions among other things. These are the factors that are often driving the trends in the industry and exploring these items might reveal means for improving U.S. manufacturing competitiveness.

This report primarily used gross operating surplus as a proxy to compare manufacturing industry profits or net income from various countries; however, there was little discussion on how closely these two items correlate. Further investigation might confirm the use of gross operating surplus as a proxy for profit; alternatively, further investigation might reveal additional data sets detailing international profits.

There are a number of expected returns that were not comprehensively examined due to data constraints: capital gains for financiers, profit from markup for retailers, and final product utilization. Further examination of these factors could provide further insight into the manufacturing industry. As discussed previously, there are also issues regarding price indices. Investigating this issue might ensure that time series data accurately reflects changes in the manufacturing industry.

\footnotetext{
${ }^{90}$ Bhide, Amar. The Venturesome Economy. (New Jersey: Princeton University Press, 2008): 21-23.
} 
With continuing concern about the loss of manufacturing competitiveness, it would be advantageous to compare professional, scientific, and technical services related to the U.S. manufacturing industry to those abroad. In recent years there has been considerable concern regarding the hollowing out of U.S. manufacturing. An examination of professional, scientific, and technical services in the U.S. and abroad might reveal the extent of this hollowing out trend. Related to this topic is the extent to which supply chain goods and services are imported versus those that are domestically provided. This issue could be examined more closely using the detailed input-output data provided by the BEA. The input-output data used in this report breaks the U.S. economy into a little over 60 sectors with 19 of them being manufacturing. The detailed input-output data breaks the economy into over 400 sectors with over 250 being manufacturing. Examination of these data could reveal important details about inter-industry activity as well as details about the import of manufactured goods. For example, the use of these data could quantify the value of the data and information services used by the manufacturing industry and each of its 250 subsectors.

Although this report depicts the manufacturing industry with a focus on medium- and high-tech industry, the sectors included in these categories are only generally identified. Although the OECD definition of high-tech is commonly used, it seems that there is not a well-established criteria for identifying what types of manufacturing are high-tech, medium-tech, or low-tech. It is often the case that authors refer to medium- and high-tech manufacturing and simply specify the industries to which they are referring. Additionally, those things that are considered high-tech today may not be considered high-tech in the future; that is, the industries in this category change over time. Thus, high-tech cannot be defined by specifying a set of subsectors; rather, it must be defined by a set of criteria. This improved clarity would provide a better understanding of those sectors that might be more advantageous to invest additional research and development.

This report has brought together multiple data sources of aggregate manufacturing industry data and industry subsector data to develop a quantitative depiction of the U.S. manufacturing industry as it relates to industry stakeholders. It then compared the industry to its international counterparts. This approach has not comprehensively explored all issues within the manufacturing industry; however, it has provided an evidence-based characterization that avoids using anecdotal data. 


\section{Literature Cited}

Atkinson, Robert D. and David B. Audretsch. "Economic Doctrines and Policy Differences: Has the Washington Policy Debate Been Asking the Wrong Questions?" The Information Technology and Innovation Foundation. September 2008. < http://www.itif.org/files/EconomicDoctrine.pdf>

Banister, Judith. "Manufacturing Employment and Compensation in China." November 2005.

<http://www.bls.gov/fls/chinareport.pdf >

BBC. "China Pollution 'Threatens Growth'.” February 28, 2011.<http://www.bbc.co.uk/news/world-asiapacific-12595872>

Beck, Robin. "Hydraulic Fracturing: The Fuss, The Facts, The Future.” Journal of Petroleum Technology. December (2010): 34-41.

Brodd, Ralph J. "Factors Affecting U.S. Production Decisions: Why are There No Volume Lithium-Ion Battery Manufacturers in the United States.” ATP Working Paper 05-01. June 2005.

<http://www.atp.nist.gov/eao/wp05-01/wp05-01.pdf>

Bhatnagar, Rohit and Amrik S. Sohal. "Supply Chain Competitiveness: Measuring the Impact of Location Factors, Uncertainty and Manufacturing Practices." Technovation. 25 (2005): 443-456.

Bhide, Amar. The Venturesome Economy. (New Jersey: Princeton University Press, 2008): 21-23.

Bureau of Economic Analysis. "U.S. Economic Accounts." <http://www.bea.gov/>

Bureau of Labor Statistics. "Producer Price Indexes: How Does the Producer Price Index Differ from the Consumer Price Index." <http://www.bls.gov/ppi/ppicpippi.htm>

Bureau of Labor Statistics. "BLS Productivity Statistics." < http://www.bls.gov/bls/productivity.htm>

Byrne, David, Brian K. Kovak, and Bryan Michaels, "Offshoring and Price Measurement in the Semiconductor Industry." In Susan N. Houseman and Kenneth F. Ryder, eds., Measurement Issues Arising from the Growth of Globalization. (Washington, DC: National Academy of Public Administration, 2010): 169-194.

Carbaugh, Robert J. International Economics. (Mason, OH, South Western Cengage Learning, 2011):78.

CBS News. “As Economy Grows, So Do China's Garbage Woes.” October 11, 2009.

<http://www.cbsnews.com/stories/2009/10/11/ap/asia/main5377158.shtml>

Census Bureau. "Annual Survey of Manufactures." < http://www.census.gov/manufacturing/asm/>

Census Bureau. "Manufacturers' Shipments, Inventories, and Orders."

$<$ http://www.census.gov/manufacturing/m3/>

Center for Public Policy Innovation. "The Decline in Semiconductor Manufacturing in the United States." June 2010. <http://cppionline.org/docs/The-Decline-of-Semiconductor-Manufacturing.pdf>

Committee on Prospering in the Global Economy of the 21st Century: An Agenda for American Science and Technology, National Academy of Sciences, National Academy of Engineering, Institute of Medicine. "Rising Above the Gathering Storm: Energizing and Employing America for a Brighter Economic Future." National Academies Press. <http://www.nap.edu/catalog.php?record_id=11463> 
Congressional Budget Office. "Factors Underlying the Decline in Manufacturing Employment Since 2000." December 23, 2008. <http://www.cbo.gov/ftpdocs/97xx/doc9749/12-23-Manufacturing.pdf>

Congressional Budget Office. "Taxing Capital Income: Effective Rates and Approaches to Reform." 2005. <http://www.cbo.gov/ftpdocs/67xx/doc6792/10-18-Tax.pdf>

Davidson, Adam. "Making It in America." The Atlantic. January/February 2012.

<http://www.theatlantic.com/magazine/archive/2012/01/making-it-in-america/8844/?single_page=true>

Davidson, Adam. "The Transformation of American Factory Jobs, In One Company." NPR. January 13, 2012. <http://www.npr.org/blogs/money/2012/01/13/145039131/the-transformation-of-american-factoryjobs-in-one-company? $\mathrm{ft}=1 \& \mathrm{f}=100>$

Davis, Bob. "The Great Property Bubble of China May be Popping.” June 9, 2011. <http://online.wsj.com/article/SB10001424052702304906004576367121835831168.html>

De Rassenfosse, G. and B. van Pottelsberghe. "A Policy Insight into the R\&D Patent Relationship." ULB Working Paper. 2008.

Economist. "Converging Economies: One-Track Bind." September 24, 2011. $<$ http://www.economist.com/node/21528985>

Economist. "The Dwindling Allure of Building Factories Offshore.” May 12, 2011. <http://www.economist.com/node/18682182?fsrc=rss\&story_id=18682182>

Engardio, Pete. "Can the Future Be Built in America." Bloomberg Businessweek. April 26, 2009. <http://www.businessweek.com/magazine/content/09_38/b4147046115750.htm>

Greenwald, Bruce C.N. and Judd Kahn. Globalization: The Irrational Fear that Someone in China will Take Your Job. (Hoboken, NJ: John Wiley \& Sons, 2009).

Hopp, Wallace J. and Mark L. Spearman. Factory Physics. Third Edition. (Long Grove, IL: Waveland Press, 2011). 37-38.

Harney, Alexandra. The China Price. (London, England: The Penguin Press, 2008).

Horowitz, Karen J. and Mark A. Planting. Concepts and Methods of the U.S. Input-Output Accounts. Bureau of Economic Analysis. 2009. <http://www.bea.gov/papers/pdf/IOmanual_092906.pdf>

Houseman, Susan. "Outsourcing, Offshoring, and Productivity Measurement in U.S. Manufacturing." Upjohn Institute Staff Working Paper No. 06-130. June 2006.

<http://www.upjohninst.org/publications/wp/06-130.pdf>

Houseman, Susan, Christopher Kurz, Paul Lengermann, and Benjamin Mandel. "Offshoring and the State of American manufacturing.” W.E. Upjohn Institute for Employment Research. June 2010.

〈http://www.upjohn.org/publications/wp/10-166.pdf>

IC Insights. Research Bulletin. April 21, 2011.

<http://www.icinsights.com/data/articles/documents/263.pdf>

Kelley, Charles, Mark Wang, Gordon Bitko, Michael Chase, Aaron Kofner, Julia Lowell, James Mulvenon, David Ortiz, and Kevin Pollpeter. "High-Technology Manufacturing and U.S. Competitiveness." RAND Technical Report. March 2004. 〈http://www.rand.org/pubs/technical_reports/2004/RAND_TR136.pdf>

Krugman, Paul. "Competitiveness, A Dangerous Obsession.” Foreign Affairs. Vol 73. Num 2. March/April (1994): 28-44. 
Krugman, Paul. "Making Sense of the Competitiveness Debate." Oxford Review of Economic Policy. Vol. 12 no. 3 (1996): 17-25.

Krugman, Paul R. and Robert Z. Lawrence. "Trade, Jobs, and Wages," Scientific American, April (1994): 22-27.

Mandel, Benjamin R. "Why is the U.S. Share of World Merchandise Exports Shrinking." Federal Reserve Bank of New York: Current Issues. Vol. 18, No. 1. 2012.

<http://www.newyorkfed.org/research/current_issues/ci18-1.pdf>

Miller, Ronald E. and Peter D. Blair. Input-Output Analysis: Foundations and Extensions. (New York: Cambridge University Press, 2009). 16.

National Public Radio. “Stopping the 'Brain Drain' of the U.S. Economy.” February 6, 2012.

<http://www.npr.org/2012/02/05/146434854/stopping-the-brain-drain-of-the-u-s-economy?ft=1\&f=100>

National Science Board. "Research and Development: Essential Foundation for U.S. Competitiveness in a Global Economy.” 2008. <http://www.nsf.gov/statistics/nsb0803/nsb0803.pdf>

National Science Foundation. “Advancing Measures of Innovation.” June 2006.

<http://www.nsf.gov/statistics/nsf07306/>

National Science Foundation. “Asia’s Rising Science and Technology Strength.” May 2007.

<http://www.nsf.gov/statistics/nsf07319/>

National Science Foundation. "Business and Industrial R\&D." <http://www.nsf.gov/statistics/industry/>

Neary, J. Peter. "Measuring Competitiveness.” IMF Working Paper WP/06/209. September 2006.

<http://www.imf.org/external/pubs/ft/wp/2006/wp06209.pdf>

Nordhaus, William. "The Sources of the Productivity Rebound and the Manufacturing Employment

Puzzle.” NBER Working Paper. May 2005. <http://www.nber.org/papers/w11354>

OECD. "Measuring Globalisation: OECD Handbook on Economic Globalisation Indicators.” May 2005. <http://www.oecd-ilibrary.org/economics/measuring-globalisation-oecd-handbook-on-economicglobalisation-indicators-2005_9789264108103-en >

OECD. OECD Patent Statistics Manual. 2009.

<http://browse.oecdbookshop.org/oecd/pdfs/free/9209021e.pdf>

OECD. "StatExtracts." <http://stats.oecd.org/Index.aspx>

Pisano, Gary P. and Willy C. Shih. Restoring American Competitiveness. Harvard Business Review. JulyAugust (2009).

Porter, Michael E. "Building the Microeconomic Foundations of Prosperity: Findings from the Business Competitiveness Index.” In Porter, Michael E., Klaus Schwab, Xavier Sala-i-Martin, and Augusta LopezClaros. The Global Competitiveness Report 2003-2004. (New York: Oxford University Press, 2004).

Porter, Michael E. The Competitive Advantage of Nations. $1^{\text {st }}$ ed. (New York: The Free Press, 1990).

Rowthorn, Robert and Ramana Ramaswamy. "Deindustrialization: Causes and Implications," International Monetary Fund Working Paper WP/97/42. April 1997. 
Schweitzer, Mark and Saeed Zaman. "Are we Engineering Ourselves out of Manufacturing Jobs." Federal Reserve Bank of Cleveland. January 2006.

<http://www.clevelandfed.org/research/commentary/2006/0101.pdf>

SEMI. Semiconductor, LED, and MEMS Fabs and Foundries. <http://www.semi.org/en/>

Shepherd, Robert J. "The People's Dynasty: Culture and Society in Modern China." Modern Scholar.

Lecture Series. 2010.

Sirkin, Harold L. "Made in the USA Still Means Something." Bloomberg Businessweek. April 10, 2009.

<http://www.businessweek.com/managing/content/apr2009/ca20090410_054122.htm>

Slaughter, Matthew J. "How U.S. Multinational Companies Strengthen the U.S. Economy." United States Council for International Business. March 2010.

$\langle$ http://www.uscib.org/docs/foundation_multinationals.pdf>

Tassey Gregory. "Rationales and Mechanisms for Revitalizing U.S. Manufacturing R\&D Strategies."

Journal of Technology Transfer. 35 (2010). 283-333.

Toder, Eric. "International Competitiveness: Who Competes Against Whom and for What?" Tax Policy

Center: Urban Institute and Brookings Institution. January 2012.

<http://www.taxpolicycenter.org/UploadedPDF/412477-international-competitiveness.pdf>

United Nations Statistics Division. "National Accounts Main Aggregates Database."

<http://unstats.un.org/unsd/snaama/Introduction.asp>

UNIDO. "Statistical Country Briefs." <http://www.unido.org/index.php?id=1000313>

UNIDO Strategic Research Database. Competitive Industrial Performance Index. 2003.

$<$ http://www.unido.org/index.php?id=5058>

UNIDO. "Industrial Development Scoreboard: Technical Notes."

$<$ http://www.unido.org/index.php?id=5058>

US-China Business Council. "US Manufacturing: Dying... Or Still Going Strong?” 2006.

<https://www.uschina.org/public/documents/2006/09/us-manufacturing.pdf>

Ward, William A. "Manufacturing Productivity and the Shifting US, China, and Global Job Scenes-1990 to 2005." Clemson University Center for International Trade Working Paper 052507. August 2005. <http://ageconsearch.umn.edu/bitstream/112948/2/citpaper12.pdf>

World Bank. World Development Indicators. Washington DC, World Bank, 2011. 314-317.

World Economic Forum. The Global Competitiveness Report. 2010-2011.

<http://www3.weforum.org/docs/WEF_GlobalCompetitivenessReport_2010-11.pdf>

Yamano, Norihiki and Nadim Ahmad. "The OECD Input-Output Database: 2006 Edition.

DSTI/DOC(2006)8. STI Working Paper 2006/8. October 2006.

<http://www.oecd.org/dataoecd/46/54/37585924.pdf>

Zhang, Kevin Honglin. "Is China the World Factory." In China as the World Factory. (New York:

Routeledge, 2006). 


\section{Appendix A: Global Competitiveness Index Rankings (World Economic Forum)}

Table A.1 below represents the Global Competitiveness Index Rankings for the United States and 8 other countries. The Global Competitiveness Report is a yearly report published by the World Economic Forum that ranks the world's nations according to the Global Competitiveness Index. This report is commonly cited in reference to competitiveness issues. The ranking uses a weighted average of multiple components, which are categorized into 12 pillars of economic competitiveness highlighted in grey: institutions, infrastructure, macroeconomic environment, health and primary education, higher education and training, goods market efficiency, labor market efficiency, financial market development, technological readiness, market size, business sophistication, and innovation. ${ }^{91}$ The ranking from each pillar was used to create Figure 3.8. In Table A.1, the pillars include subcategories. Although this index measures the economy as a whole, it does provide insight into areas related to manufacturing. Note that the red bars are a visual comparison between countries; the shorter the bar the higher the ranking is when compared to the countries shown. Subcategories are highlighted in yellow if the U.S. ranks below the $70^{\text {th }}$ percentile (ranks at or below $42^{\text {nd }}$ ) and red if it is below the $50^{\text {th }}$ percentile (ranks at or below $70^{\text {th }}$ ). The overall rank for the U.S. was $4^{\text {th }}$ while Switzerland, Sweden, and Singapore were ranked $1^{\text {st }}, 2^{\text {nd }}$, and $3^{\text {rd }}$ respectively.

\footnotetext{
${ }^{91}$ World Economic Forum. The Global Competitiveness Report. 2010-2011. <http://www3.weforum.org/docs/WEF_GlobalCompetitivenessReport_2010-11.pdf>
} 
Table A.1: Global Competitiveness Index Rankings among 139 countries (World Economic Forum), 2010-2011

\begin{tabular}{|c|c|c|c|c|c|c|c|c|c|c|c|c|c|}
\hline & United States & Australia & & Canada & & China & Germany & India & & Japan & Mexico & & UK \\
\hline \multirow[t]{2}{*}{ Overall Rank } & 4 & 16 & I & 10 & L & 27 & 5 & 51 & 1 & 6 & 66 & 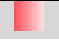 & 12 \\
\hline & United States & Australia & \multicolumn{2}{|r|}{ Canada } & & China & Germany & India & \multicolumn{2}{|r|}{ Japan } & Mexico & \multicolumn{2}{|r|}{ UK } \\
\hline \multirow{4}{*}{$\begin{array}{l}\text { Market size } \\
\text { Domestic market size index } \\
\text { foreign market size index }\end{array}$} & 1 & 18 & 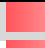 & 14 & $T$ & 2 & 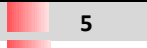 & Z & I & 3 & 12 & 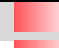 & 6 \\
\hline & 1 & 17 & 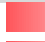 & 14 & I & 2 & 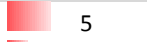 & 4 & I & 3 & 11 & 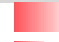 & 6 \\
\hline & 2 & 30 & 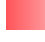 & 18 & I & 1 & 3 & 4 & 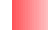 & 9 & 15 & 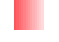 & 5 \\
\hline & United States & Australia & \multicolumn{2}{|r|}{ Canada } & \multicolumn{2}{|r|}{ China } & Germany & India & \multicolumn{2}{|r|}{ Japan } & Mexico & \multicolumn{2}{|r|}{ UK } \\
\hline Innovation & 4 & 21 & I & 11 & $T$ & 26 & 8 & 39 & 1 & 4 & 78 & 1 & 14 \\
\hline University-industry collaboration in R\&D & 1 & 13 & 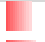 & 7 & 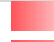 & 25 & 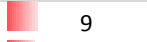 & 58 & L & 19 & 59 & I & 4 \\
\hline Utility patents per million population & 3 & 17 & 1 & 10 & 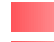 & 51 & I. & 59 & I & 2 & 60 & 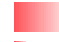 & 20 \\
\hline Quality of scientific research institutions & 4 & 10 & D & 8 & E & 39 & I & 30 & 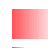 & 15 & 60 & 】 & 3 \\
\hline Availability of scientists and engineers & 【 & 45 & I & 6 & 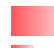 & 35 & 27 & 15 & 【 & 2 & 89 & E & 29 \\
\hline Gov't procurement of advanced tech products & 5 & 37 & 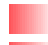 & 26 & I & 12 & 32 & 76 & 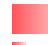 & 41 & 96 & 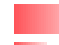 & 53 \\
\hline Capacity for innovation & 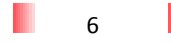 & 23 & P & 19 & 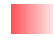 & 21 & 1 & 33 & I & 2 & 86 & 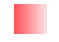 & 15 \\
\hline \multirow[t]{2}{*}{ Company spending on $R \& D$} & 【 & 23 & 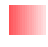 & 20 & 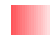 & 22 & 4 & 37 & 【 & 3 & 90 & I & 14 \\
\hline & United States & Australia & \multicolumn{2}{|r|}{ Canada } & & China & Germany & India & \multicolumn{2}{|r|}{ Japan } & Mexico & & UK \\
\hline Labor Market Efficiency & 4 & 11 & T & 6 & 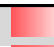 & 38 & 70 & 92 & 1 & 13 & 120 & 1 & 8 \\
\hline Rigidity of employment & 1 & 1 & I. & 8 & L & 78 & 108 & 77 & 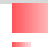 & 36 & 104 & 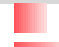 & 18 \\
\hline Redundancy costs & 1 & 6 & 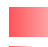 & 55 & t & 114 & 98 & 89 & I & 6 & 81 & 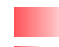 & 40 \\
\hline Brain drain & 3 & 22 & I & 9 & $=$ & 37 & 31 & 34 & 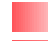 & 26 & 74 & 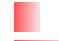 & 10 \\
\hline Hiring and firing practices & 6 & 79 & I & 15 & 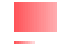 & 62 & 133 & 89 & 口 & 121 & 120 & 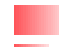 & 49 \\
\hline Pay and productivity & 9 & 53 & 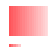 & 30 & 【 & 15 & 43 & 61 & I & 12 & 98 & 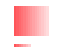 & 25 \\
\hline Reliance on professional management & 15 & 8 & ! & 5 & & 50 & 14 & 49 & 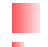 & 16 & 102 & $\underline{1}$ & 7 \\
\hline Cooperation in labor-employer relations & 33 & 43 & 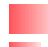 & 28 & $=$ & 58 & 18 & 49 & I & 7 & 74 & 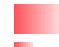 & 26 \\
\hline Flexibility of wage determination & 34 & 110 & 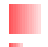 & 33 & & 56 & 136 & 61 & I & 15 & 92 & I & 20 \\
\hline Female participation in labor force & 49 & 51 & I & 24 & 【 & 23 & 44 & 128 & & 88 & 117 & 1 & 47 \\
\hline
\end{tabular}




\begin{tabular}{|c|c|c|c|c|c|c|c|c|c|c|c|}
\hline & United States & Australia & Canada & China & Germany & India & & Japan & Mexico & & UK \\
\hline Business sophistication & 8 & 29 & 16 & 41 & 3 & 44 & 1 & 1 & 67 & $T$ & 9 \\
\hline Extent of marketing & 1 & 16 & 10 & 49 & 7 & 57 & 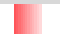 & 9 & 72 & I & 4 \\
\hline State of cluster development & 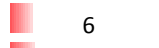 & 35 & 11 & 17 & 12 & 29 & I & 2 & 50 & 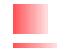 & 10 \\
\hline Control of international distribution & 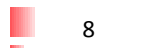 & 31 & 36 & 42 & 2 & 64 & I & 1 & 76 & 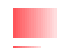 & 19 \\
\hline Willingness to delegate authority & 8 & 12 & 7 & 68 & 9 & 48 & I & 13 & 86 & 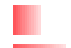 & 16 \\
\hline Local supplier quantity & 11 & 37 & 20 & 19 & 3 & 7 & 【 & 1 & 71 & 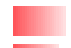 & 23 \\
\hline Production process sophistication & 11 & 24 & 15 & 55 & 2 & 43 & I & 1 & 61 & 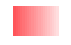 & 17 \\
\hline Local supplier quality & 14 & 16 & 7 & 54 & 3 & 60 & I & 4 & 55 & 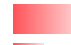 & 30 \\
\hline Value chain breadth & 15 & 78 & 33 & 41 & 1 & 42 & I & 2 & 49 & 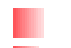 & 11 \\
\hline \multirow[t]{2}{*}{ Nature of competititive advantage } & 19 & 59 & 56 & 48 & 3 & 61 & 【 & 1 & 85 & D & 9 \\
\hline & United States & Australia & Canada & China & Germany & India & & Japan & Mexico & & UK \\
\hline Higher education and training & 9 & 14 & 8 & 60 & 19 & 85 & 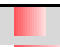 & 20 & 79 & 1 & 18 \\
\hline Tertiary education enrollment rate & 6 & 13 & 27 & 88 & 52 & 101 & 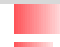 & 34 & 80 & 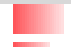 & 35 \\
\hline Local availability of research and training services & 10 & 20 & 11 & 50 & 2 & 51 & 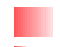 & 13 & 55 & 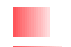 & 12 \\
\hline Extent of staff training & 10 & 20 & 12 & 57 & 8 & 59 & I & 6 & 84 & $\mathbf{E}$ & 28 \\
\hline Quality of management schools & 11 & 17 & 3 & 63 & 31 & 23 & L & 65 & 52 & I & 10 \\
\hline Internet access in schools & 14 & 28 & 13 & 22 & 39 & 70 & 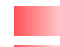 & 40 & 89 & I & 18 \\
\hline Quality of the educational system & 26 & 12 & 5 & 53 & 18 & 39 & 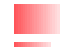 & 35 & 120 & 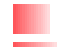 & 28 \\
\hline Secondary education enrollment rate & 45 & 1 & 19 & 92 & 18 & 108 & 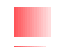 & 21 & 61 & 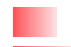 & 28 \\
\hline \multirow[t]{2}{*}{ Quality of math and science education } & 52 & 24 & 10 & 33 & 39 & 38 & 1 & 28 & 128 & + & 55 \\
\hline & United States & Australia & Canada & China & Germany & India & & Japan & Mexico & & UK \\
\hline Infrastructure & 15 & 22 & 9 & 50 & 2 & 86 & 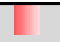 & 11 & 75 & 1 & 8 \\
\hline Available airline seat kilometers & 1 & 6 & 10 & 2 & 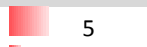 & 12 & 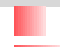 & 4 & 20 & I & 3 \\
\hline Fixed telephone lines & 16 & 23 & 12 & 57 & 5 & 110 & 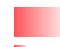 & 34 & 72 & I & 11 \\
\hline Quality of railroad infrastructure & 18 & 26 & 16 & 27 & 5 & 23 & I & 3 & 76 & 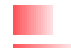 & 19 \\
\hline Quality of roads & 19 & 30 & 17 & 53 & 5 & 90 & 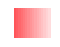 & 22 & 62 & 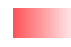 & 35 \\
\hline Quality of port infrastructure & 22 & 46 & 14 & 67 & 5 & 83 & 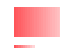 & 37 & 89 & 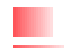 & 23 \\
\hline Quality of overall infrastructure & 23 & 34 & 13 & 72 & 9 & 91 & I & 15 & 79 & 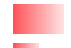 & 33 \\
\hline Quality of electricity supply & 23 & 33 & 14 & 52 & 6 & 110 & I & 5 & 91 & D. & 15 \\
\hline Quality of air transport infrastructure & 32 & 30 & 23 & 79 & 3 & 71 & & 54 & 65 & 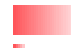 & 34 \\
\hline Mobile telephone subscriptions & 71 & 42 & 100 & 111 & 26 & 118 & & 75 & 93 & I & 24 \\
\hline
\end{tabular}




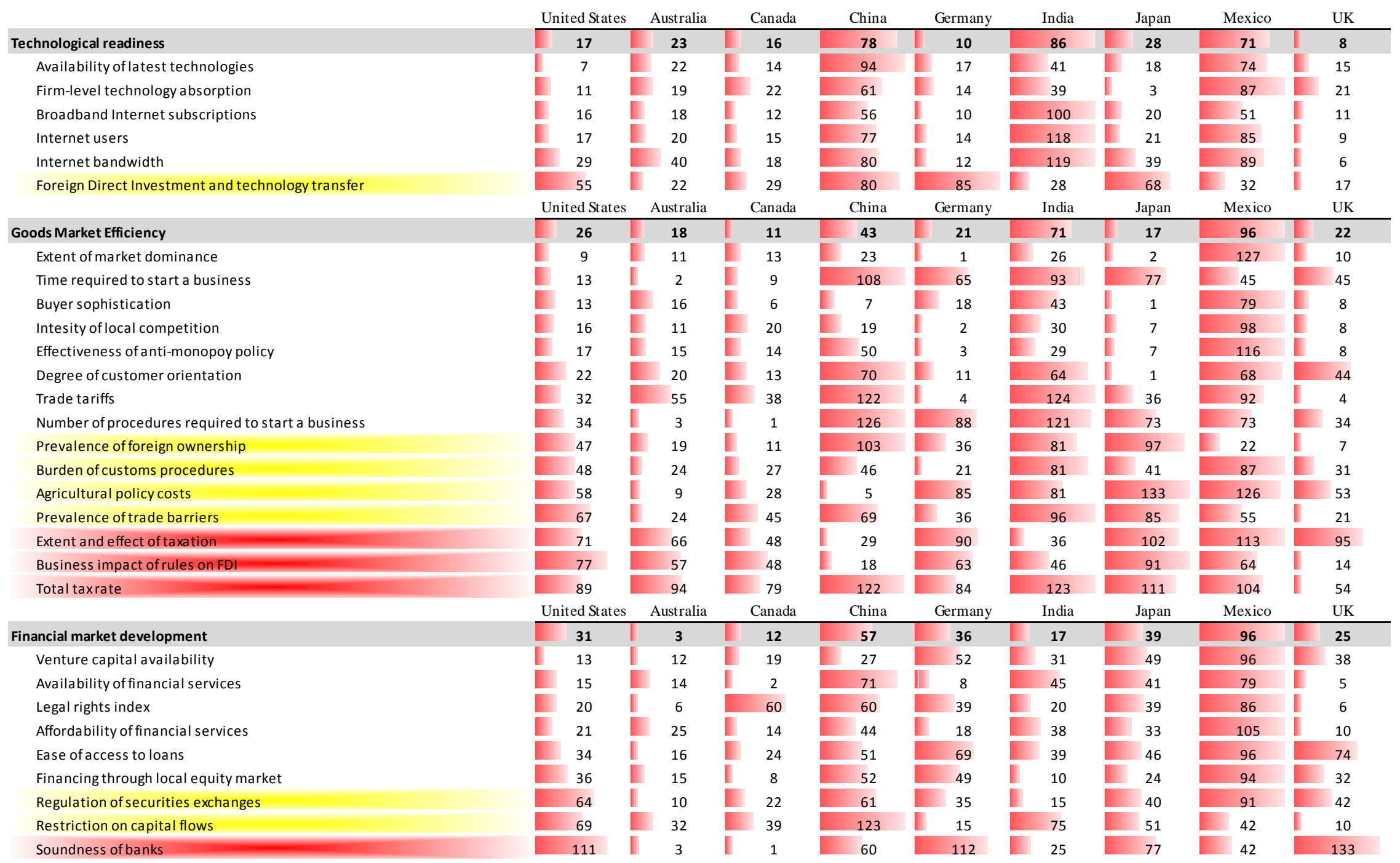




\begin{tabular}{|c|c|c|c|c|c|c|c|c|c|c|}
\hline & United States & Australia & Canada & China & Germany & India & Japan & Mexico & & UK \\
\hline Instititutions & 40 & 14 & 11 & 49 & 13 & 58 & 25 & 106 & I & 17 \\
\hline Strength of investor protection & 5 & 45 & 5 & 77 & 77 & 33 & 16 & 33 & I & 10 \\
\hline Intellectual property protection & 24 & 14 & 13 & 49 & 9 & 66 & 21 & 85 & D & 17 \\
\hline Reliability of police services & 26 & 19 & 7 & 51 & 12 & 68 & 22 & 132 & 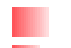 & 31 \\
\hline Efficacy of corporate boards & 28 & 7 & 4 & 85 & 15 & 76 & 19 & 112 & 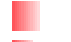 & 16 \\
\hline Ethical behavior of firms & 30 & 10 & 8 & 55 & 13 & 70 & 18 & 93 & 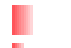 & 14 \\
\hline Efficiency of legal framework in settling disputes & 33 & 12 & 14 & 44 & 15 & 47 & 27 & 102 & 】 & 8 \\
\hline Diversion of public funds & 34 & 13 & 16 & 55 & 14 & 71 & 27 & 98 & 【 & 11 \\
\hline Judicial independence & 35 & 9 & 11 & 62 & 5 & 41 & 20 & 92 & I & 8 \\
\hline Efficiency of legal fra mework in challenging regulations & 35 & 13 & 18 & 51 & 8 & 37 & 33 & 77 & 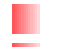 & 16 \\
\hline Property rights & 40 & 14 & 10 & 38 & 8 & 61 & 23 & 88 & I & 17 \\
\hline Irregular Payments and bribes & 40 & 16 & 12 & 63 & 20 & 83 & 11 & 91 & 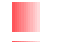 & 21 \\
\hline Protection of minority shareholders' interests & 40 & 15 & 8 & 66 & 13 & 55 & 27 & 81 & 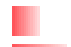 & 17 \\
\hline Transparency of government policymaking & 41 & 19 & 11 & 38 & 13 & 42 & 48 & 79 & 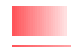 & 34 \\
\hline Burden of government regulation & 49 & 60 & 41 & 21 & 92 & 95 & 70 & 116 & L & 89 \\
\hline Public trust of politicians & 54 & 17 & 23 & 22 & 29 & 88 & 58 & 94 & 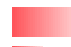 & 55 \\
\hline favoritism in decisions of government officials & 55 & 19 & 20 & 37 & 16 & 72 & 14 & 83 & I & 23 \\
\hline Strength of auditing and reporting standards & 55 & 14 & 6 & 61 & 21 & 45 & 33 & 68 & 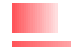 & 22 \\
\hline Wastefulness of government spending & 68 & 21 & 32 & 35 & 33 & 57 & 91 & 81 & 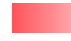 & 72 \\
\hline Business costs of crime and violence & 84 & 45 & 49 & 47 & 23 & 67 & 53 & 132 & 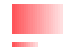 & 55 \\
\hline Organized crime & 86 & 32 & 50 & 76 & 28 & 73 & 71 & 136 & I & 39 \\
\hline \multirow[t]{2}{*}{ Business costs of terrorism } & 125 & 80 & 96 & 79 & 56 & 127 & 95 & 112 & 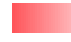 & 99 \\
\hline & United States & Australia & Canada & China & Germany & India & Japan & Mexico & & UK \\
\hline Health and Primary Education & 42 & 13 & 6 & 37 & 25 & 104 & 9 & 70 & 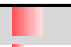 & 19 \\
\hline Business impact of malaria & 1 & 1 & 1 & 90 & 1 & 102 & 1 & 74 & I & 1 \\
\hline Malaria incidence & 1 & 1 & 1 & 80 & 1 & 108 & 1 & 81 & 【 & 1 \\
\hline Tuberculosis incidence & 6 & 20 & 8 & 86 & 9 & 101 & 45 & 42 & 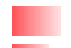 & 32 \\
\hline Life expectancy & 34 & 7 & 11 & 70 & 19 & 109 & 1 & 51 & 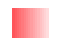 & 21 \\
\hline Quality of primary education & 34 & 14 & 9 & 35 & 36 & 98 & 20 & 120 & 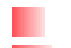 & 27 \\
\hline Infant mortality & 41 & 28 & 35 & 75 & 20 & 111 & 6 & 70 & 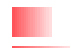 & 28 \\
\hline Business impact of tuberculosis & 53 & 35 & 9 & 74 & 11 & 87 & 50 & 44 & 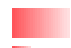 & 36 \\
\hline Primary education enrollment rate & 79 & 42 & 8 & 7 & 27 & 95 & 2 & 29 & I & 6 \\
\hline Business impact of HIV/AIDS & 80 & 53 & 25 & 56 & 12 & 99 & 42 & 78 & & 54 \\
\hline HIV prevalence & 89 & 55 & 77 & 22 & 22 & 71 & 1 & 71 & & 55 \\
\hline
\end{tabular}




\begin{tabular}{|c|c|c|c|c|c|c|c|c|c|}
\hline & United States & Australia & Canada & China & Germany & India & Japan & Mexico & UK \\
\hline Macroeconomic Environment & 87 & 17 & 36 & 4 & 23 & 73 & 105 & 28 & 56 \\
\hline Country credit rating & 11 & 14 & 4 & 32 & 6 & 50 & 16 & 45 & 18 \\
\hline Inflation & 15 & 49 & 24 & 10 & 20 & 123 & 4 & 96 & 54 \\
\hline Interest rate spread & 26 & 35 & 20 & 33 & 28 & 65 & I & 62 & 2 \\
\hline Government budget balance & 118 & 67 & 34 & 35 & 26 & 81 & 134 & 19 & 117 \\
\hline Government debt & 122 & 23 & 120 & 18 & 114 & 115 & 137 & 50 & 108 \\
\hline National savings rate & 130 & 46 & 80 & 3 & 56 & 9 & 51 & 59 & 107 \\
\hline
\end{tabular}




\section{Appendix B: IMD World Competitiveness Yearbook, 2011}

The World Competitiveness Yearbook is a product of the International Institute for Management Development's (IMD) World Competitiveness Center. The Yearbook is a ranking of nations based on their ability to create and maintain an environment where enterprises can compete. This environment is broken into 4 factors: economic performance, government efficiency, business efficiency, and infrastructure. Each of these factors is broken into 5 sub-factors for a total of 20, which are given equal weight in determining overall rank among the 59 countries evaluated. There are over 300 criteria used to determine the sub-factors. The rankings for the U.S. and a selection of other nations are shown below. Note that the red bars are a visual comparison between countries; the shorter the bar the higher the ranking is when compared to the countries shown. Subcategories are highlighted in yellow if the U.S. ranks below the $70^{\text {th }}$ percentile and red if it is below the $50^{\text {th }}$ percentile.

\section{Table B.1: IMD World Competitiveness Yearbook}

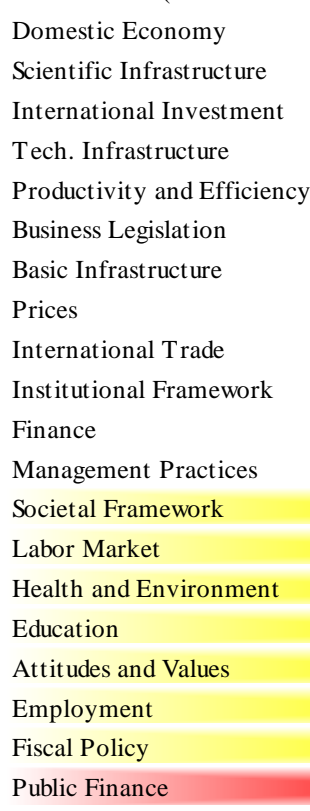

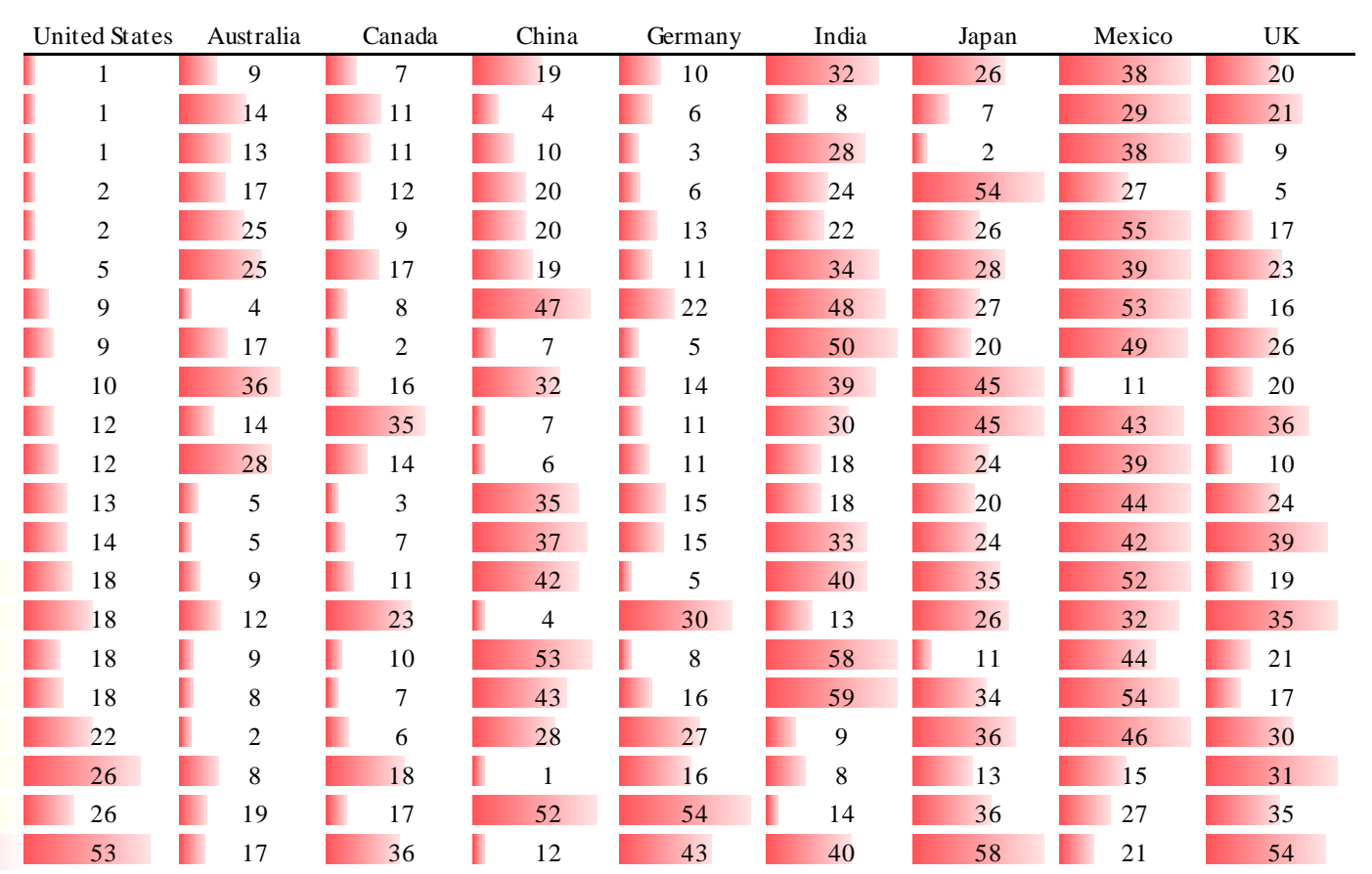




\section{Appendix C: Annual Survey of Manufactures, Medium- and High-Tech Sectors (2009)}

The Annual Survey of Manufactures (ASM) is conducted every year except for years ending in 2 or 7 when the Economic Census is conducted. The ASM provides statistics

on employment, payroll, supplemental labor costs, cost of materials consumed, operating expenses, value of shipments, value added, fuels and energy used, and inventories. It uses a sample survey of approximately 50000 establishments with new samples selected at 5year intervals. The ASM data allow the examination of multiple factors (value added, payroll, energy use, and more) of manufacturing at a detailed subsector level. The Economic Census, used for years ending in 2 or 7, is a survey of all employer establishments in the U.S. that has been taken as an integrated program at 5-year intervals since 1967. Both the ASM and the Economic Census use NAICS classification; however, prior to NAICS the Standard Industrial Classification system was used. Detailed 2009 data is shown in Table C.1, which contains the number of employees, value added, total value of shipments, net income, and other metrics for chemical manufacturing (NAICS 325); machinery manufacturing (NAICS 333); computer and electronic products manufacturing (NAICS 334); electrical equipment, appliance, and component manufacturing (NAICS 335); and transportation equipment manufacturing (NAICS 336) along with all the subsectors. 
Table C.1: Annual Survey of Manufactures: Medium- and High-tech Sectors

$\begin{array}{ll}325 & \text { Chemical mfg } \\ 3251 & \text { Basic chemical mfg } \\ 32511 & \text { Petrochemical manufacturing } \\ 325110 & \text { Petrochemical manufacturing } \\ 32512 & \text { Industrial gas manufacturing } \\ 325120 & \text { Industrial gas manufacturing } \\ 32513 & \text { Synthetic dye and pigment manufacturing } \\ 32513 \mathrm{M} & \text { Synthetic dye and pigment manufacturing } \\ 32518 & \text { Other basic inorganic chemical manufacturing } \\ 325181 & \text { Alkalies and chlorine manufacturing } \\ 325182 & \text { Carbon black manufacturing } \\ 325188 & \text { All other basic inorganic chemical manufacturing } \\ 32519 & \text { Other basic organic chemical manufacturing } \\ 32519 \mathrm{M} & \text { Other basic organic chemical manufacturing } \\ 3252 & \text { Resin, syn rubber, \& artificial syn fibers \& filaments mfg } \\ 32521 & \text { Resin and synthetic rubber manufacturing } \\ 325211 & \text { Plastics material and resin manufacturing } \\ 325212 & \text { Synthetic rubber manufacturing } \\ 32522 & \text { Artificial and synthetic fibers and filaments manufacturing } \\ 32522 \mathrm{M} & \text { Artificial and synthetic fibers and filaments manufacturing } \\ 3253 & \text { Pesticide, fertilizer, \& other agricultural chemical mfg } \\ 32531 & \text { Fertilizer manufacturing } \\ 325311 & \text { Nitrogenous fertilizer manufacturing } \\ 325312 & \text { Phosphatic fertilizer manufacturing } \\ 325314 & \text { Fertilizer (mixing only) manufacturing } \\ 32532 & \text { Pesticide and other agricultural chemical manufacturing } \\ 325320 & \text { Pesticide and other agricultural chemical manufacturing } \\ 3254 & \text { Pharmaceutical \& medicine mfg } \\ 32541 & \text { Pharmaceutical and medicine manufacturing } \\ 325411 & \text { Medicinal and botanical manufacturing } \\ & \end{array}$

\begin{tabular}{|c|c|c|c|c|c|c|c|}
\hline $\begin{array}{l}\text { Number of } \\
\text { Employees }\end{array}$ & $\begin{array}{l}\text { Value Added } \\
\quad(\$ 1000)\end{array}$ & $\begin{array}{c}\text { Total Value of } \\
\text { Shipments } \\
(\$ 1000)\end{array}$ & $\begin{array}{l}\text { Net Income } \\
\quad(\$ 1000)\end{array}$ & $\begin{array}{c}\text { Compensation } \\
\text { per Employee } \\
(\$ 1000)\end{array}$ & $\begin{array}{l}\text { Value Added } \\
\text { per Employee } \\
\quad(\$ 1000)\end{array}$ & $\begin{array}{l}\text { Net Income } \\
\text { per Employee } \\
\quad(\$ 1000)\end{array}$ & $\begin{array}{c}\text { Net Income } \\
\text { per } \\
\text { Expenditure } \\
\text { Dollar }(\$ 1000)\end{array}$ \\
\hline 724683 & 328870852 & 628945803 & 181231086 & 85.9 & 453.8 & 250.1 & 0.426 \\
\hline 142143 & 66710327 & 175439319 & 24952054 & 93.6 & 469.3 & 175.5 & 0.176 \\
\hline 9167 & 18846611 & 52086422 & 14466939 & 127.9 & 2055.9 & 1578.2 & 0.399 \\
\hline 9167 & 18846611 & 52086422 & 14466939 & 127.9 & 2055.9 & 1578.2 & 0.399 \\
\hline 9287 & 4930678 & 7499403 & 1999242 & 90.5 & 530.9 & 215.3 & 0.405 \\
\hline 9287 & 4930678 & 7499403 & 1999242 & 90.5 & 530.9 & 215.3 & 0.405 \\
\hline 9549 & 3070544 & 6212514 & 1332338 & 87.8 & 321.6 & 139.5 & 0.300 \\
\hline 9549 & 3070544 & 6212514 & 1332338 & 87.8 & 321.6 & 139.5 & 0.300 \\
\hline 37420 & 16066348 & 27796541 & 6801242 & 95.4 & 429.4 & 181.8 & 0.343 \\
\hline 5973 & 2856531 & 5376112 & 1026361 & 108.7 & 478.2 & 171.8 & 0.247 \\
\hline 1489 & 418525 & 1183144 & 78401 & 87.3 & 281.1 & 52.7 & 0.078 \\
\hline 29958 & 12791293 & 21237284 & 5696477 & 93.2 & 427.0 & 190.1 & 0.389 \\
\hline 76720 & 23796146 & 81844439 & 352292 & 89.7 & 310.2 & 4.6 & 0.005 \\
\hline 76720 & 23796146 & 81844439 & 352292 & 89.7 & 310.2 & 4.6 & 0.005 \\
\hline 81177 & 27236501 & 72112280 & 10442794 & 82.7 & 335.5 & 128.6 & 0.178 \\
\hline 67932 & 25447365 & 66857343 & 10359499 & 87.3 & 374.6 & 152.5 & 0.192 \\
\hline 59202 & 23057280 & 60744217 & 9844146 & 85.9 & 389.5 & 166.3 & 0.203 \\
\hline 8730 & 2390085 & 6113126 & 515353 & 96.8 & 273.8 & 59.0 & 0.095 \\
\hline 13246 & 1789136 & 5254937 & 83297 & 59.5 & 135.1 & 6.3 & 0.017 \\
\hline 13246 & 1789136 & 5254937 & 83297 & 59.5 & 135.1 & 6.3 & 0.017 \\
\hline 26794 & 16142416 & 32950257 & 8938460 & 75.5 & 602.5 & 333.6 & 0.396 \\
\hline 17373 & 8704599 & 20963464 & 3753707 & 74.8 & 501.0 & 216.1 & 0.235 \\
\hline 3950 & 3775018 & 7054673 & 2188935 & 92.9 & 955.7 & 554.2 & 0.492 \\
\hline 6065 & 3012934 & 8688260 & 834340 & 83.6 & 496.8 & 137.6 & 0.115 \\
\hline 7358 & 1916647 & 5220531 & 730431 & 58.0 & 260.5 & 99.3 & 0.169 \\
\hline 9422 & 7437817 & 11986793 & 5184755 & 76.6 & 789.4 & 550.3 & 0.788 \\
\hline 9422 & 7437817 & 11986793 & 5184755 & 76.6 & 789.4 & 550.3 & 0.788 \\
\hline 236439 & 140568339 & 191409938 & 94384540 & 99.9 & 594.5 & 399.2 & 1.018 \\
\hline 236439 & 140568339 & 191409938 & 94384540 & 99.9 & 594.5 & 399.2 & 1.018 \\
\hline 26647 & 6868675 & 10780248 & 2088565 & 94.9 & 257.8 & 78.4 & 0.253 \\
\hline
\end{tabular}




$\begin{array}{ll}325412 & \text { Pharmaceutical preparation manufacturing } \\ 325413 & \text { In-vitro diagnostic substance manufacturing } \\ 325414 & \text { Biological product (except diagnostic) manufacturing } \\ 3255 & \text { Paint, coating, \& adhesive mfg } \\ 32551 & \text { Paint and coating manufacturing } \\ 325510 & \text { Paint and coating manufacturing } \\ 32552 & \text { Adhesive manufacturing } \\ 325520 & \text { Adhesive manufacturing } \\ 3256 & \text { Soap, cleaning compound, \& toilet preparation mfg } \\ 32561 & \text { Soap and cleaning compound manufacturing } \\ 32561 \mathrm{M} & \text { Soap and cleaning compound manufacturing } \\ 32562 & \text { Toilet preparation manufacturing } \\ 325620 & \text { Toilet preparation manufacturing } \\ 3259 & \text { Other chemical product \& preparation mfg } \\ 32591 & \text { Printing ink manufacturing } \\ 325910 & \text { Printing ink manufacturing } \\ 32592 & \text { Explosives manufacturing } \\ 325920 & \text { Explosives manufacturing } \\ 32599 & \text { All other chemical product and preparation manufacturing } \\ 325991 & \text { Custom compounding of purchased resins } \\ 32599 \mathrm{~N} & \text { All other miscellaneous chemical product and preparation mfg } \\ 333 & \text { Machinery mfg } \\ 3331 & \text { Agriculture, construction, \& mining machinery mfg } \\ 33311 & \text { Agricultural implement manufacturing } \\ 333111 & \text { Farm machinery and equipment manufacturing } \\ 333112 & \text { Lawn and garden equipment manufacturing } \\ 33312 & \text { Construction machinery manufacturing } \\ 333120 & \text { Construction machinery manufacturing } \\ 33313 & \text { Mining and oil and gas field machinery manufacturing } \\ 33313 \mathrm{M} & \text { Mining and oil and gas field machinery manufacturing } \\ 3332 & \text { Industrial machinery mfg } \\ 33321 & \text { Sawmill and woodworking machinery manufacturing } \\ & \\ 32\end{array}$

\begin{tabular}{|c|c|c|c|c|c|c|c|}
\hline $\begin{array}{l}\text { Number of } \\
\text { Employees }\end{array}$ & $\begin{array}{l}\text { Value Added } \\
\quad(\$ 1000)\end{array}$ & $\begin{array}{l}\text { Total Value of } \\
\text { Shipments } \\
(\$ 1000)\end{array}$ & $\begin{array}{l}\text { Net Income } \\
\quad(\$ 1000)\end{array}$ & $\begin{array}{c}\text { Compensation } \\
\text { per Employee } \\
(\$ 1000)\end{array}$ & $\begin{array}{c}\text { Value Added } \\
\text { per Employee } \\
\quad(\$ 1000)\end{array}$ & $\begin{array}{l}\text { Net Income } \\
\text { per Employee } \\
(\$ 1000)\end{array}$ & $\begin{array}{c}\text { Net Income } \\
\text { per } \\
\text { Expenditure } \\
\text { Dollar }(\$ 1000) \\
\end{array}$ \\
\hline 143792 & 106165160 & 141936232 & 78832874 & 98.3 & 738.3 & 548.2 & 1.315 \\
\hline 26516 & 8134126 & 11878476 & 2507315 & 107.0 & 306.8 & 94.6 & 0.275 \\
\hline 39484 & 19400377 & 26814983 & 10955785 & 104.5 & 491.3 & 277.5 & 0.711 \\
\hline 54419 & 14000152 & 29202317 & 6960821 & 70.9 & 257.3 & 127.9 & 0.325 \\
\hline 33873 & 9703320 & 19630904 & 5345374 & 72.4 & 286.5 & 157.8 & 0.388 \\
\hline 33873 & 9703320 & 19630904 & 5345374 & 72.4 & 286.5 & 157.8 & 0.388 \\
\hline 20545 & 4296831 & 9571413 & 1615450 & 68.4 & 209.1 & 78.6 & 0.212 \\
\hline 20545 & 4296831 & 9571413 & 1615450 & 68.4 & 209.1 & 78.6 & 0.212 \\
\hline 97604 & 44800949 & 86992023 & 28531518 & 69.5 & 459.0 & 292.3 & 0.507 \\
\hline 43612 & 24824391 & 48470784 & 16739308 & 72.4 & 569.2 & 383.8 & 0.550 \\
\hline 43612 & 24824391 & 48470784 & 16739308 & 72.4 & 569.2 & 383.8 & 0.550 \\
\hline 53992 & 19976559 & 38521239 & 11792207 & 67.1 & 370.0 & 218.4 & 0.458 \\
\hline 53992 & 19976559 & 38521239 & 11792207 & 67.1 & 370.0 & 218.4 & 0.458 \\
\hline 86106 & 19412167 & 40839669 & 7020901 & 68.7 & 225.4 & 81.5 & 0.217 \\
\hline 12131 & 1827126 & 4265317 & 331346 & 63.0 & 150.6 & 27.3 & 0.086 \\
\hline 12131 & 1827126 & 4265317 & 331346 & 63.0 & 150.6 & 27.3 & 0.086 \\
\hline 6303 & 1177942 & 2045937 & 388698 & 70.8 & 186.9 & 61.7 & 0.241 \\
\hline 6303 & 1177942 & 2045937 & 388698 & 70.8 & 186.9 & 61.7 & 0.241 \\
\hline 67672 & 16407100 & 34528415 & 6300854 & 69.5 & 242.5 & 93.1 & 0.234 \\
\hline 16712 & 2276233 & 7297569 & 372921 & 63.8 & 136.2 & 22.3 & 0.056 \\
\hline 50959 & 14130867 & 27230846 & 5927935 & 71.4 & 277.3 & 116.3 & 0.292 \\
\hline 962083 & 133056578 & 287634198 & 24575525 & 66.0 & 138.3 & 25.5 & 0.097 \\
\hline 180379 & 31666182 & 75886277 & 9652216 & 66.0 & 175.6 & 53.5 & 0.151 \\
\hline 70923 & 12752651 & 30933763 & 5410521 & 61.2 & 179.8 & 76.3 & 0.219 \\
\hline 51595 & 10826116 & 23612919 & 5224116 & 65.8 & 209.8 & 101.3 & 0.294 \\
\hline 19328 & 1926535 & 7320844 & 186408 & 48.7 & 99.7 & 9.6 & 0.027 \\
\hline 56142 & 9503183 & 24689398 & 2329963 & 63.1 & 169.3 & 41.5 & 0.110 \\
\hline 56142 & 9503183 & 24689398 & 2329963 & 63.1 & 169.3 & 41.5 & 0.110 \\
\hline 53314 & 9410347 & 20263115 & 1911728 & 75.4 & 176.5 & 35.9 & 0.105 \\
\hline 53314 & 9410347 & 20263115 & 1911728 & 75.4 & 176.5 & 35.9 & 0.105 \\
\hline 109976 & 12272993 & 26417663 & -1769644 & 74.6 & 111.6 & -16.1 & -0.066 \\
\hline 3689 & 239619 & 466533 & -50750 & 48.8 & 65.0 & -13.8 & -0.105 \\
\hline
\end{tabular}




$\begin{array}{ll}333210 & \text { Sawmill and woodworking machinery manufacturing } \\ 33322 & \text { Plastics and rubber industry machinery manufacturing } \\ 333220 & \text { Plastics and rubber industry machinery manufacturing } \\ 33329 & \text { Other industrial machinery manufacturing } \\ 333295 & \text { Semiconductor machinery manufacturing } \\ 33329 \mathrm{~N} & \text { Other machinery manufacturing } \\ 3333 & \text { Commercial \& service industry machinery mfg } \\ 33331 & \text { Commercial and service industry machinery manufacturing } \\ 333313 & \text { Office machinery manufacturing } \\ 333314 & \text { Optical instrument and lens manufacturing } \\ 333315 & \text { Photographic and photocopying equipment manufacturing } \\ 33331 \mathrm{~N} & \text { All other commercial and service industry machinery mfg } \\ 3334 & \text { Ventilation, heating, AC, \& commercial refrigeration equip mfg } \\ 33341 & \text { HVAC and commercial refrigeration equipment manufacturing } \\ 333414 & \text { Heating equipment (except warm air furnaces) manufacturing } \\ 333415 & \text { AC, forced air heating, and refrigeration equipment mfg } \\ 33341 \mathrm{~N} & \text { Ventilation equipment manufacturing } \\ 3335 & \text { Metalworking machinery mfg } \\ 33351 & \text { Metalworking machinery manufacturing } \\ 333511 & \text { Industrial mold manufacturing } \\ 333512 & \text { Machine tool (metal cutting types) manufacturing } \\ 333513 & \text { Machine tool (metal forming types) manufacturing } \\ 333514 & \text { Special die and tool, die set, jig, and fixture manufacturing } \\ 333515 & \text { Cutting tool and machine tool accessory manufacturing } \\ 333516 & \text { Rolling mill machinery and equipment manufacturing } \\ 333518 & \text { Other metalworking machinery manufacturing } \\ 3336 & \text { Engine, turbine, \& power transmission equipment mfg } \\ 33361 & \text { Engine, turbine, and power transmission equipment mfg } \\ 333611 & \text { Turbine and turbine generator set unit manufacturing } \\ 333612 & \text { Speed changer, industrial high-speed drive, and gear mfg } \\ 333613 & \text { Mechanical power transmission equipment manufacturing } \\ 333618 & \text { Other engine equipment manufacturing } \\ & \end{array}$

\begin{tabular}{|c|c|c|c|c|c|c|c|}
\hline $\begin{array}{l}\text { Number of } \\
\text { Employees }\end{array}$ & $\begin{array}{l}\text { Value Added } \\
\quad(\$ 1000)\end{array}$ & $\begin{array}{c}\text { Total Value of } \\
\text { Shipments } \\
(\$ 1000)\end{array}$ & $\begin{array}{l}\text { Net Income } \\
\quad(\$ 1000)\end{array}$ & $\begin{array}{c}\text { Compensation } \\
\text { per Employee } \\
(\$ 1000)\end{array}$ & $\begin{array}{c}\text { Value Added } \\
\text { per Employee } \\
\quad(\$ 1000)\end{array}$ & $\begin{array}{l}\text { Net Income } \\
\text { per Employee } \\
(\$ 1000)\end{array}$ & $\begin{array}{c}\text { Net Income } \\
\text { per } \\
\text { Expenditure } \\
\text { Dollar }(\$ 1000) \\
\end{array}$ \\
\hline 3689 & 239619 & 466533 & -50750 & 48.8 & 65.0 & -13.8 & -0.105 \\
\hline 12627 & 1366600 & 2959693 & -13934 & 65.8 & 108.2 & -1.1 & -0.005 \\
\hline 12627 & 1366600 & 2959693 & -13934 & 65.8 & 108.2 & -1.1 & -0.005 \\
\hline 93660 & 10666774 & 22991436 & -1689804 & 76.8 & 113.9 & -18.0 & -0.072 \\
\hline 19362 & 1731996 & 5704230 & -2389732 & 104.7 & 89.5 & -123.4 & -0.311 \\
\hline 74297 & 8934778 & 17287206 & 699929 & 69.6 & 120.3 & 9.4 & 0.045 \\
\hline 75385 & 11039940 & 20930670 & 2693144 & 67.7 & 146.4 & 35.7 & 0.153 \\
\hline 75385 & 11039940 & 20930670 & 2693144 & 67.7 & 146.4 & 35.7 & 0.153 \\
\hline 5333 & 988941 & 1659541 & 457775 & 70.1 & 185.4 & 85.8 & 0.395 \\
\hline 16348 & 2384283 & 4673039 & 217089 & 82.2 & 145.8 & 13.3 & 0.051 \\
\hline 5503 & 1096295 & 1975217 & 482483 & 66.1 & 199.2 & 87.7 & 0.335 \\
\hline 48201 & 6570422 & 12622873 & 1535796 & 62.7 & 136.3 & 31.9 & 0.143 \\
\hline 126063 & 15970899 & 34646153 & 4485617 & 55.6 & 126.7 & 35.6 & 0.153 \\
\hline 126063 & 15970899 & 34646153 & 4485617 & 55.6 & 126.7 & 35.6 & 0.153 \\
\hline 16539 & 1951684 & 3786626 & -183262 & 59.7 & 118.0 & -11.1 & -0.048 \\
\hline 86454 & 11641118 & 26308906 & 4222576 & 55.8 & 134.7 & 48.8 & 0.197 \\
\hline 23070 & 2378097 & 4550622 & 446303 & 51.9 & 103.1 & 19.3 & 0.113 \\
\hline 129596 & 11970310 & 20604679 & -639099 & 62.9 & 92.4 & -4.9 & -0.032 \\
\hline 129596 & 11970310 & 20604679 & -639099 & 62.9 & 92.4 & -4.9 & -0.032 \\
\hline 30488 & 2807137 & 4221870 & -152699 & 60.8 & 92.1 & -5.0 & -0.037 \\
\hline 15652 & 1732273 & 3473464 & -300061 & 72.8 & 110.7 & -19.2 & -0.084 \\
\hline 6223 & 620475 & 1217675 & 20517 & 64.6 & 99.7 & 3.3 & 0.018 \\
\hline 40528 & 3496247 & 5745328 & -236893 & 61.9 & 86.3 & -5.8 & -0.042 \\
\hline 26469 & 2208315 & 3502270 & 28929 & 55.4 & 83.4 & 1.1 & 0.009 \\
\hline 3068 & 394536 & 789668 & 80055 & 73.1 & 128.6 & 26.1 & 0.109 \\
\hline 7168 & 711328 & 1654404 & -78949 & 77.9 & 99.2 & -11.0 & -0.048 \\
\hline 89434 & 12546873 & 35462893 & 899134 & 68.3 & 140.3 & 10.1 & 0.027 \\
\hline 89434 & 12546873 & 35462893 & 899134 & 68.3 & 140.3 & 10.1 & 0.027 \\
\hline 26200 & 4126854 & 11873050 & 686358 & 77.6 & 157.5 & 26.2 & 0.063 \\
\hline 12100 & 1481069 & 2787931 & 115969 & 61.1 & 122.4 & 9.6 & 0.047 \\
\hline 13718 & 1796014 & 3300479 & 378400 & 62.8 & 130.9 & 27.6 & 0.137 \\
\hline 37416 & 5142936 & 17501433 & -281594 & 66.2 & 137.5 & -7.5 & -0.017 \\
\hline
\end{tabular}




$\begin{array}{ll}3339 & \text { Other general purpose machinery mfg } \\ 33391 & \text { Pump and compressor manufacturing } \\ 333911 & \text { Pump and pumping equipment manufacturing } \\ 333912 & \text { Air and gas compressor manufacturing } \\ 333913 & \text { Measuring and dispensing pump manufacturing } \\ 33392 & \text { Material handling equipment manufacturing } \\ 33392 \mathrm{M} & \text { Material handling equipment manufacturing } \\ 33399 & \text { All other general purpose machinery manufacturing } \\ 333991 & \text { Power-driven hand tool manufacturing } \\ 333993 & \text { Packaging machinery manufacturing } \\ 333994 & \text { Industrial process furnace and oven manufacturing } \\ 33399 \mathrm{~N} & \text { Fluid power equipment manufacturing } \\ 33399 \mathrm{P} & \text { All other miscellaneous general purpose machinery mfg } \\ 334 & \text { Computer \& electronic product mfg } \\ 3341 & \text { Computer \& peripheral equipment mfg } \\ 33411 & \text { Computer and peripheral equipment manufacturing } \\ 334111 & \text { Electronic computer manufacturing } \\ 334112 & \text { Computer storage device manufacturing } \\ 334113 & \text { Computer terminal manufacturing } \\ 334119 & \text { Other computer peripheral equipment manufacturing } \\ 3342 & \text { Communications equipment mfg } \\ 33421 & \text { Telephone apparatus manufacturing } \\ 334210 & \text { Telephone apparatus manufacturing } \\ 33422 & \text { Broadcasting and wireless communications equipment mfg } \\ 334220 & \text { Broadcasting and wireless communications equipment mfg } \\ 33429 & \text { Other communications equipment manufacturing } \\ 334290 & \text { Other communications equipment manufacturing } \\ 3343 & \text { Audio \& video equipment mfg } \\ 33431 & \text { Audio and video equipment manufacturing } \\ 334310 & \text { Audio and video equipment manufacturing } \\ 3344 & \text { Semiconductor \& other electronic component mfg } \\ 33441 & \text { Semiconductor and other electronic component manufacturing }\end{array}$

\begin{tabular}{|c|c|c|c|c|c|c|c|}
\hline $\begin{array}{l}\text { Number of } \\
\text { Employees }\end{array}$ & $\begin{array}{l}\text { Value Added } \\
\quad(\$ 1000)\end{array}$ & $\begin{array}{l}\text { Total Value of } \\
\text { Shipments } \\
(\$ 1000)\end{array}$ & $\begin{array}{l}\text { Net Income } \\
\quad(\$ 1000)\end{array}$ & $\begin{array}{c}\text { Compensation } \\
\text { per Employee } \\
(\$ 1000)\end{array}$ & $\begin{array}{c}\text { Value Added } \\
\text { per Employee } \\
\quad(\$ 1000)\end{array}$ & $\begin{array}{l}\text { Net Income } \\
\text { per Employee } \\
\quad(\$ 1000)\end{array}$ & $\begin{array}{c}\text { Net Income } \\
\text { per } \\
\text { Expenditure } \\
\text { Dollar }(\$ 1000) \\
\end{array}$ \\
\hline 251250 & 37589382 & 73685863 & 9254154 & 67.9 & 149.6 & 36.8 & 0.147 \\
\hline 55175 & 11400046 & 20927621 & 4186622 & 76.2 & 206.6 & 75.9 & 0.249 \\
\hline 31108 & 6167791 & 11461531 & 1965195 & 77.7 & 198.3 & 63.2 & 0.214 \\
\hline 19866 & 4558489 & 8375152 & 2057085 & 75.9 & 229.5 & 103.5 & 0.308 \\
\hline 4201 & 673766 & 1090937 & 164343 & 66.6 & 160.4 & 39.1 & 0.179 \\
\hline 73853 & 10950707 & 23479360 & 3314426 & 61.0 & 148.3 & 44.9 & 0.167 \\
\hline 73853 & 10950707 & 23479360 & 3314426 & 61.0 & 148.3 & 44.9 & 0.167 \\
\hline 122223 & 15238628 & 29278883 & 1753107 & 68.3 & 124.7 & 14.3 & 0.066 \\
\hline 5032 & 822091 & 1563263 & 369862 & 56.6 & 163.4 & 73.5 & 0.337 \\
\hline 17451 & 2052170 & 4127960 & 95187 & 74.6 & 117.6 & 5.5 & 0.024 \\
\hline 9766 & 1116524 & 2071558 & 154303 & 65.4 & 114.3 & 15.8 & 0.083 \\
\hline 29148 & 3449954 & 6965101 & 171745 & 71.2 & 118.4 & 5.9 & 0.027 \\
\hline 60826 & 7797889 & 14551000 & 962011 & 66.5 & 128.2 & 15.8 & 0.073 \\
\hline 908299 & 193242334 & 327991364 & 51326615 & 84.5 & 212.8 & 56.5 & 0.194 \\
\hline 90407 & 25973603 & 52530237 & 11156089 & 72.6 & 287.3 & 123.4 & 0.277 \\
\hline 90407 & 25973603 & 52530237 & 11156089 & 72.6 & 287.3 & 123.4 & 0.277 \\
\hline 39640 & 18163961 & 36155504 & 10003285 & 82.1 & 458.2 & 252.4 & 0.390 \\
\hline 13683 & 3195160 & 6321021 & 753694 & 67.8 & 233.5 & 55.1 & 0.141 \\
\hline 1678 & 217110 & 467003 & 21272 & 89.2 & 129.4 & 12.7 & 0.048 \\
\hline 35406 & 4397372 & 9586709 & 377839 & 63.1 & 124.2 & 10.7 & 0.043 \\
\hline 115293 & 24940758 & 45164081 & 6546738 & 89.3 & 216.3 & 56.8 & 0.172 \\
\hline 23938 & 3637637 & 8551513 & 548649 & 77.4 & 152.0 & 22.9 & 0.070 \\
\hline 23938 & 3637637 & 8551513 & 548649 & 77.4 & 152.0 & 22.9 & 0.070 \\
\hline 76502 & 19002222 & 32610694 & 5415116 & 95.9 & 248.4 & 70.8 & 0.202 \\
\hline 76502 & 19002222 & 32610694 & 5415116 & 95.9 & 248.4 & 70.8 & 0.202 \\
\hline 14853 & 2300898 & 4001873 & 582974 & 74.2 & 154.9 & 39.2 & 0.173 \\
\hline 14853 & 2300898 & 4001873 & 582974 & 74.2 & 154.9 & 39.2 & 0.173 \\
\hline 10283 & 1463934 & 3275474 & -269072 & 61.0 & 142.4 & -26.2 & -0.081 \\
\hline 10283 & 1463934 & 3275474 & -269072 & 61.0 & 142.4 & -26.2 & -0.081 \\
\hline 10283 & 1463934 & 3275474 & -269072 & 61.0 & 142.4 & -26.2 & -0.081 \\
\hline 293537 & 58360636 & 96459857 & 13056896 & 71.9 & 198.8 & 44.5 & 0.173 \\
\hline 293537 & 58360636 & 96459857 & 13056896 & 71.9 & 198.8 & 44.5 & 0.173 \\
\hline
\end{tabular}


334411

334412

334413

334414

334415

334416

334417

334418

334419

3345

33451

334510

334511

334512

334513

334514

334515

334516

334517

334518

334519 Other measuring and controlling device manufacturing

3346 Mfg \& reproducing magnetic \& optical media

33461 Manufacturing and reproducing magnetic and optical media

334611 Software reproducing

334612 Audio and video media reproducing

334613 Magnetic and optical recording media manufacturing

335 Electrical equipment, appliance, \& component mfg

$3351 \quad$ Electric lighting equipment $\mathrm{mfg}$

33511 Electric lamp bulb and parts manufacturing

335110 Electric lamp bulb and parts manufacturing

$33512 \quad$ Lighting fixture manufacturing

33512M Lighting fixture manufacturing

\begin{tabular}{|c|c|c|c|c|c|c|c|}
\hline $\begin{array}{l}\text { Number of } \\
\text { Employees }\end{array}$ & $\begin{array}{l}\text { Value Added } \\
\quad(\$ 1000)\end{array}$ & $\begin{array}{c}\text { Total Value of } \\
\text { Shipments } \\
(\$ 1000)\end{array}$ & $\begin{array}{l}\text { Net Income } \\
\quad(\$ 1000)\end{array}$ & $\begin{array}{c}\text { Compensation } \\
\text { per Employee } \\
(\$ 1000)\end{array}$ & $\begin{array}{l}\text { Value Added } \\
\text { per Employee } \\
\quad(\$ 1000)\end{array}$ & $\begin{array}{l}\text { Net Income } \\
\text { per Employee } \\
\quad(\$ 1000)\end{array}$ & $\begin{array}{c}\text { Net Income } \\
\text { per } \\
\text { Expenditure } \\
\text { Dollar }(\$ 1000) \\
\end{array}$ \\
\hline 4992 & 591801 & 1106990 & -24634 & 70.8 & 118.5 & -4.9 & -0.023 \\
\hline 24772 & 2101606 & 3749722 & 102827 & 50.9 & 84.8 & 4.2 & 0.029 \\
\hline 120257 & 41433504 & 59240375 & 11930457 & 92.3 & 344.5 & 99.2 & 0.292 \\
\hline 6108 & 499912 & 824102 & 25809 & 48.7 & 81.8 & 4.2 & 0.035 \\
\hline 3876 & 339677 & 548694 & -11329 & 54.7 & 87.6 & -2.9 & -0.022 \\
\hline 10029 & 773421 & 1687131 & 7979 & 51.2 & 77.1 & 0.8 & 0.005 \\
\hline 19424 & 2575532 & 3987346 & 652273 & 61.7 & 132.6 & 33.6 & 0.208 \\
\hline 59171 & 5455307 & 17332394 & 388101 & 58.1 & 92.2 & 6.6 & 0.024 \\
\hline 44910 & 4589874 & 7983103 & -1471 & 60.5 & 102.2 & 0.0 & 0.000 \\
\hline 375344 & 79359432 & 125081153 & 20331363 & 97.9 & 211.4 & 54.2 & 0.198 \\
\hline 375344 & 79359432 & 125081153 & 20331363 & 97.9 & 211.4 & 54.2 & 0.198 \\
\hline 63926 & 16469553 & 24913089 & 5157889 & 98.7 & 257.6 & 80.7 & 0.267 \\
\hline 142920 & 33399152 & 50552170 & 10000996 & 111.4 & 233.7 & 70.0 & 0.249 \\
\hline 10646 & 1476840 & 2474232 & 378049 & 68.2 & 138.7 & 35.5 & 0.184 \\
\hline 32563 & 4772189 & 7688300 & 685862 & 73.8 & 146.6 & 21.1 & 0.101 \\
\hline 12384 & 2323936 & 4961859 & 813849 & 74.2 & 187.7 & 65.7 & 0.197 \\
\hline 31163 & 5233149 & 7987445 & 167041 & 93.9 & 167.9 & 5.4 & 0.022 \\
\hline 36827 & 7687180 & 12177335 & 1244580 & 95.3 & 208.7 & 33.8 & 0.116 \\
\hline 14361 & 2989021 & 6036626 & 703942 & 107.4 & 208.1 & 49.0 & 0.133 \\
\hline 1678 & 186132 & 330417 & - & 59.7 & 110.9 & - & - \\
\hline 28876 & 4822280 & 7959681 & 1154040 & 83.1 & 167.0 & 40.0 & 0.176 \\
\hline 23436 & 3143970 & 5480561 & 504596 & 62.2 & 134.2 & 21.5 & 0.108 \\
\hline 23436 & 3143970 & 5480561 & 504596 & 62.2 & 134.2 & 21.5 & 0.108 \\
\hline 2498 & 355831 & 624192 & - & 60.7 & 142.4 & - & - \\
\hline 14973 & 2047940 & 2811913 & 638754 & 50.4 & 136.8 & 42.7 & 0.320 \\
\hline 5965 & 740199 & 2044456 & - & 92.5 & 124.1 & - & - \\
\hline 352940 & 50498178 & 106650713 & 13768428 & 61.8 & 143.1 & 39.0 & 0.155 \\
\hline 47784 & 5814469 & 11540560 & 739537 & 58.5 & 121.7 & 15.5 & 0.071 \\
\hline 7719 & 957935 & 1941446 & -56916 & 73.3 & 124.1 & -7.4 & -0.030 \\
\hline 7719 & 957935 & 1941446 & -56916 & 73.3 & 124.1 & -7.4 & -0.030 \\
\hline 40065 & 4856534 & 9599114 & 796454 & 55.7 & 121.2 & 19.9 & 0.094 \\
\hline 40065 & 4856534 & 9599114 & 796454 & 55.7 & 121.2 & 19.9 & 0.094 \\
\hline
\end{tabular}




$\begin{array}{ll}3352 & \text { Household appliance mfg } \\ 33521 & \text { Small electrical appliance manufacturing } \\ 33521 \mathrm{M} & \text { Small electrical appliance manufacturing } \\ 33522 & \text { Major appliance manufacturing } \\ 335221 & \text { Household cooking appliance manufacturing } \\ 335222 & \text { Household refrigerator and home freezer manufacturing } \\ 335224 & \text { Household laundry equipment manufacturing } \\ 335228 & \text { Other major household appliance manufacturing } \\ 3353 & \text { Electrical equipment mfg } \\ 33531 & \text { Electrical equipment manufacturing } \\ 335311 & \text { Power, distribution, and specialty transformer manufacturing } \\ 335312 & \text { Motor and generator manufacturing } \\ 335313 & \text { Switchgear and switchboard apparatus manufacturing } \\ 335314 & \text { Relay and industrial control manufacturing } \\ 3359 & \text { Other electrical equipment \& component mfg } \\ 33591 & \text { Battery manufacturing } \\ 335911 & \text { Storage battery manufacturing } \\ 335912 & \text { Primary battery manufacturing } \\ 33592 & \text { Communication and energy wire and cable manufacturing } \\ 33592 \mathrm{M} & \text { Communication and energy wire and cable manufacturing } \\ 33593 & \text { Wiring device manufacturing } \\ 33593 \mathrm{M} & \text { Wiring device manufacturing } \\ 33599 & \text { All other electrical equipment and component manufacturing } \\ 335991 & \text { Carbon and graphite product manufacturing } \\ 335999 & \text { All other miscellaneous electrical equipment mfg } \\ 336 & \text { Transportation equipment mfg } \\ 3361 & \text { Motor vehicle mfg } \\ 33611 & \text { Automobile and light duty motor vehicle manufacturing } \\ 336111 & \text { Automobile manufacturing } \\ 336112 & \text { Light truck and utility vehicle manufacturing } \\ 33612 & \text { Heavy duty truck manufacturing } \\ 336120 & \text { Heavy duty truck manufacturing } \\ & \end{array}$

\begin{tabular}{|c|c|c|c|c|c|c|c|}
\hline $\begin{array}{l}\text { Number of } \\
\text { Employees }\end{array}$ & $\begin{array}{l}\text { Value Added } \\
\qquad(\$ 1000)\end{array}$ & $\begin{array}{l}\text { Total Value of } \\
\text { Shipments } \\
(\$ 1000)\end{array}$ & $\begin{array}{l}\text { Net Income } \\
(\$ 1000)\end{array}$ & $\begin{array}{c}\text { Compensation } \\
\text { per Employee } \\
(\$ 1000)\end{array}$ & $\begin{array}{c}\text { Value Added } \\
\text { per Employee } \\
\quad(\$ 1000)\end{array}$ & $\begin{array}{l}\text { Net Income } \\
\text { per Employee } \\
(\$ 1000)\end{array}$ & $\begin{array}{c}\text { Net Income } \\
\text { per } \\
\text { Expenditure } \\
\text { Dollar }(\$ 1000) \\
\end{array}$ \\
\hline 48581 & 8451085 & 18707942 & 3289821 & 55.6 & 174.0 & 67.7 & 0.227 \\
\hline 10676 & 1883992 & 3875919 & 549109 & 52.0 & 176.5 & 51.4 & 0.189 \\
\hline 10676 & 1883992 & 3875919 & 549109 & 52.0 & 176.5 & 51.4 & 0.189 \\
\hline 37905 & 6567093 & 14832023 & 2740713 & 56.6 & 173.3 & 72.3 & 0.237 \\
\hline 10014 & 1438911 & 3835185 & 540600 & 47.6 & 143.7 & 54.0 & 0.176 \\
\hline 10449 & 1707879 & 3649074 & 704189 & 62.4 & 163.4 & 67.4 & 0.247 \\
\hline 7927 & 1295279 & 3357541 & - & 57.3 & 163.4 & - & - \\
\hline 9516 & 2125024 & 3990223 & - & 59.1 & 223.3 & - & - \\
\hline 124722 & 17929414 & 36420717 & 5816333 & 62.5 & 143.8 & 46.6 & 0.198 \\
\hline 124722 & 17929414 & 36420717 & 5816333 & 62.5 & 143.8 & 46.6 & 0.198 \\
\hline 19185 & 2891941 & 5989002 & 837196 & 60.3 & 150.7 & 43.6 & 0.169 \\
\hline 37640 & 5098260 & 10855168 & 1851752 & 55.3 & 135.4 & 49.2 & 0.217 \\
\hline 33917 & 5289214 & 10598214 & 1689870 & 68.2 & 155.9 & 49.8 & 0.195 \\
\hline 33980 & 4649998 & 8978333 & 1437516 & 66.2 & 136.8 & 42.3 & 0.199 \\
\hline 131852 & 18303209 & 39981495 & 3922735 & 64.5 & 138.8 & 29.8 & 0.114 \\
\hline 25666 & 4187587 & 9220680 & 1693654 & 61.7 & 163.2 & 66.0 & 0.236 \\
\hline 18430 & 2379930 & 5508397 & 577409 & 59.6 & 129.1 & 31.3 & 0.124 \\
\hline 7235 & 1807657 & 3712283 & 1116249 & 66.9 & 249.8 & 154.3 & 0.442 \\
\hline 29566 & 3969359 & 11404357 & 966411 & 60.7 & 134.3 & 32.7 & 0.095 \\
\hline 29566 & 3969359 & 11404357 & 966411 & 60.7 & 134.3 & 32.7 & 0.095 \\
\hline 39558 & 5490955 & 9901061 & 1595780 & 58.8 & 138.8 & 40.3 & 0.204 \\
\hline 39558 & 5490955 & 9901061 & 1595780 & 58.8 & 138.8 & 40.3 & 0.204 \\
\hline 37063 & 4655309 & 9455398 & -333112 & 75.5 & 125.6 & -9.0 & -0.036 \\
\hline 7790 & 874379 & 1982585 & -186283 & 62.2 & 112.2 & -23.9 & -0.093 \\
\hline 29273 & 3780930 & 7472813 & -146827 & 79.1 & 129.2 & -5.0 & -0.020 \\
\hline 1240320 & 229642082 & 545018370 & 65962476 & 78.9 & 185.1 & 53.2 & 0.141 \\
\hline 123484 & 41968097 & 149900446 & 19353433 & 93.6 & 339.9 & 156.7 & 0.154 \\
\hline 101510 & 38798362 & 134129035 & 18707916 & 98.0 & 382.2 & 184.3 & 0.168 \\
\hline 51440 & 13338967 & 53724061 & 3335421 & 95.8 & 259.3 & 64.8 & 0.069 \\
\hline 50070 & 25459395 & 80404974 & 15372495 & 100.1 & 508.5 & 307.0 & 0.245 \\
\hline 21974 & 3169734 & 15771411 & 645516 & 73.7 & 144.2 & 29.4 & 0.044 \\
\hline 21974 & 3169734 & 15771411 & 645516 & 73.7 & 144.2 & 29.4 & 0.044 \\
\hline
\end{tabular}




$\begin{array}{ll}3362 & \text { Motor vehicle body \& trailer mfg } \\ 33621 & \text { Motor vehicle body and trailer manufacturing } \\ 336211 & \text { Motor vehicle body manufacturing } \\ 336212 & \text { Truck trailer manufacturing } \\ 336213 & \text { Motor home manufacturing } \\ 336214 & \text { Travel trailer and camper manufacturing } \\ 3363 & \text { Motor vehicle parts mfg } \\ 33631 & \text { Motor vehicle gasoline engine and engine parts manufacturing } \\ 33631 \mathrm{M} & \text { Motor vehicle gasoline engine and engine parts manufacturing } \\ 33632 & \text { Motor vehicle electrical and electronic equipment mfg } \\ 33632 \mathrm{M} & \text { Motor vehicle electrical and electronic equipment mfg } \\ 33633 & \text { Motor vehicle steering and suspension component mfg } \\ 336330 & \text { Motor vehicle steering and suspension component mfg } \\ 33634 & \text { Motor vehicle brake system manufacturing } \\ 336340 & \text { Motor vehicle brake system manufacturing } \\ 33635 & \text { Motor vehicle transmission and power train parts mfg } \\ 336350 & \text { Motor vehicle transmission and power train parts mfg } \\ 33636 & \text { Motor vehicle seating and interior trim manufacturing } \\ 336360 & \text { Motor vehicle seating and interior trim manufacturing } \\ 33637 & \text { Motor vehicle metal stamping } \\ 336370 & \text { Motor vehicle metal stamping } \\ 33639 & \text { Other motor vehicle parts manufacturing } \\ 336391 & \text { Motor vehicle air-conditioning manufacturing } \\ 336399 & \text { All other miscellaneous motor vehicle parts manufacturing } \\ 3364 & \text { Aerospace product \& parts mfg } \\ 33641 & \text { Aerospace product and parts manufacturing } \\ 336411 & \text { Aircraft manufacturing } \\ 336412 & \text { Aircraft engine and engine parts manufacturing } \\ 336413 & \text { Other aircraft parts and auxiliary equipment manufacturing } \\ 336414 & \text { Guided missile and space vehicle manufacturing } \\ 336415 & \text { Space vehicle propulsion unit and propulsion unit parts mfg } \\ 336419 & \text { Other guided missile and space vehicle parts manufacturing } \\ & \end{array}$

\begin{tabular}{|c|c|c|c|c|c|c|c|}
\hline $\begin{array}{l}\text { Number of } \\
\text { Employees }\end{array}$ & $\begin{array}{l}\text { Value Added } \\
(\$ 1000)\end{array}$ & $\begin{array}{l}\text { Total Value of } \\
\text { Shipments } \\
(\$ 1000)\end{array}$ & $\begin{array}{l}\text { Net Income } \\
\quad(\$ 1000)\end{array}$ & $\begin{array}{c}\text { Compensation } \\
\text { per Employee } \\
(\$ 1000)\end{array}$ & $\begin{array}{l}\text { Value Added } \\
\text { per Employee } \\
(\$ 1000)\end{array}$ & $\begin{array}{l}\text { Net Income } \\
\text { per Employee } \\
\quad(\$ 1000)\end{array}$ & $\begin{array}{c}\text { Net Income } \\
\text { per } \\
\text { Expenditure } \\
\text { Dollar }(\$ 1000) \\
\end{array}$ \\
\hline 89012 & 6877283 & 21289121 & 5190 & 49.9 & 77.3 & 0.1 & 0.000 \\
\hline 89012 & 6877283 & 21289121 & 5190 & 49.9 & 77.3 & 0.1 & 0.000 \\
\hline 37561 & 3099055 & 9571235 & -111467 & 54.0 & 82.5 & -3.0 & -0.012 \\
\hline 17781 & 1341215 & 4094631 & 68530 & 47.1 & 75.4 & 3.9 & 0.018 \\
\hline 6889 & 454220 & 1715710 & -37815 & 47.9 & 65.9 & -5.5 & -0.023 \\
\hline 26781 & 1982792 & 5907545 & 85943 & 46.6 & 74.0 & 3.2 & 0.015 \\
\hline 403660 & 51569867 & 130520776 & 5401701 & 62.5 & 127.8 & 13.4 & 0.046 \\
\hline 43338 & 6673109 & 16122589 & 983186 & 70.1 & 154.0 & 22.7 & 0.070 \\
\hline 43338 & 6673109 & 16122589 & 983186 & 70.1 & 154.0 & 22.7 & 0.070 \\
\hline 51816 & 6250356 & 13796310 & 483295 & 65.1 & 120.6 & 9.3 & 0.038 \\
\hline 51816 & 6250356 & 13796310 & 483295 & 65.1 & 120.6 & 9.3 & 0.038 \\
\hline 33338 & 3032241 & 8092743 & -83538 & 54.7 & 91.0 & -2.5 & -0.011 \\
\hline 33338 & 3032241 & 8092743 & -83538 & 54.7 & 91.0 & -2.5 & -0.011 \\
\hline 20021 & 2994044 & 7541072 & 890961 & 55.7 & 149.5 & 44.5 & 0.142 \\
\hline 20021 & 2994044 & 7541072 & 890961 & 55.7 & 149.5 & 44.5 & 0.142 \\
\hline 46946 & 9417340 & 21046860 & 1385509 & 85.1 & 200.6 & 29.5 & 0.076 \\
\hline 46946 & 9417340 & 21046860 & 1385509 & 85.1 & 200.6 & 29.5 & 0.076 \\
\hline 37555 & 3906049 & 12941768 & 283320 & 56.3 & 104.0 & 7.5 & 0.023 \\
\hline 37555 & 3906049 & 12941768 & 283320 & 56.3 & 104.0 & 7.5 & 0.023 \\
\hline 65146 & 7562837 & 17738909 & 383861 & 63.8 & 116.1 & 5.9 & 0.024 \\
\hline 65146 & 7562837 & 17738909 & 383861 & 63.8 & 116.1 & 5.9 & 0.024 \\
\hline 105501 & 11733891 & 33240525 & 1075104 & 53.1 & 111.2 & 10.2 & 0.035 \\
\hline 11201 & 903056 & 3539306 & -317057 & 56.8 & 80.6 & -28.3 & -0.087 \\
\hline 94300 & 10830835 & 29701219 & 1392161 & 52.7 & 114.9 & 14.8 & 0.052 \\
\hline 429777 & 99173054 & 178924241 & 35161491 & 99.3 & 230.8 & 81.8 & 0.238 \\
\hline 429777 & 99173054 & 178924241 & 35161491 & 99.3 & 230.8 & 81.8 & 0.238 \\
\hline 182045 & 49349285 & 95409243 & 19771945 & 104.7 & 271.1 & 108.6 & 0.248 \\
\hline 63393 & 14726478 & 29573759 & 5755190 & 88.3 & 232.3 & 90.8 & 0.252 \\
\hline 110853 & 21622751 & 32050688 & 8248127 & 84.1 & 195.1 & 74.4 & 0.341 \\
\hline 50338 & 9646809 & 16141661 & 758293 & 128.9 & 191.6 & 15.1 & 0.047 \\
\hline 15486 & 3076885 & 4521328 & 773901 & 103.1 & 198.7 & 50.0 & 0.216 \\
\hline 7662 & 750847 & 1227563 & -145963 & 79.4 & 98.0 & -19.1 & -0.111 \\
\hline
\end{tabular}


3365 Railroad rolling stock mfg

$33651 \quad$ Railroad rolling stock manufacturing

336510 Railroad rolling stock manufacturing

$3366 \quad$ Ship \& boat building

$33661 \quad$ Ship and boat building

336611 Ship building and repairing

336612 Boat building

3369 Other transportation equipment $\mathrm{mfg}$

33699 Other transportation equipment manufacturing

336991 Motorcycle, bicycle, and parts manufacturing

336992 Military armored vehicle, tank, and tank component mfg

336999 All other transportation equipment manufacturing

\begin{tabular}{cccccccc}
$\begin{array}{c}\text { Number of } \\
\text { Employees }\end{array}$ & $\begin{array}{c}\text { Value Added } \\
(\$ 1000)\end{array}$ & $\begin{array}{c}\text { Total Value of } \\
\text { Shipments } \\
(\$ 1000)\end{array}$ & $\begin{array}{c}\text { Net Income } \\
(\$ 1000)\end{array}$ & $\begin{array}{c}\text { Compensation } \\
\text { per Employee } \\
(\$ 1000)\end{array}$ & $\begin{array}{c}\text { Value Added } \\
\text { per Employee } \\
(\$ 1000)\end{array}$ & $\begin{array}{c}\text { Net Income } \\
\text { per Employee } \\
(\$ 1000)\end{array}$ & $\begin{array}{c}\text { Net Income } \\
\text { per } \\
\text { Expenditure } \\
\text { Dollar }(\$ 1000)\end{array}$ \\
\hline 25078 & 4352692 & 12019211 & 1055417 & 77.0 & 173.6 & 42.1 & 0.098 \\
25078 & 4352692 & 12019211 & 1055417 & 77.0 & 173.6 & 42.1 & 0.098 \\
25078 & 4352692 & 12019211 & 1055417 & 77.0 & 173.6 & 42.1 & 0.098 \\
126824 & 16322216 & 27247521 & 1021226 & 69.8 & 128.7 & 8.1 & 0.040 \\
126824 & 16322216 & 27247521 & 1021226 & 69.8 & 128.7 & 8.1 & 0.040 \\
100372 & 14125452 & 21801484 & 1468171 & 75.7 & 140.7 & 14.6 & 0.074 \\
26453 & 2196764 & 5446037 & -446947 & 47.5 & 83.0 & -16.9 & -0.082 \\
42485 & 9378874 & 25117054 & 3964019 & 75.9 & 220.8 & 93.3 & 0.192 \\
42485 & 9378874 & 25117054 & 3964019 & 75.9 & 220.8 & 93.3 & 0.192 \\
10506 & 2456478 & 5097019 & 924983 & 63.7 & 233.8 & 88.0 & 0.236 \\
20285 & 5222991 & 14807987 & 2807727 & 87.4 & 257.5 & 138.4 & 0.237 \\
11695 & 1699406 & 5212048 & 231308 & 66.9 & 145.3 & 19.8 & 0.048
\end{tabular}




\section{Appendix D: Schematic Data Map (ASM)}

The Annual Survey of Manufactures (ASM) is conducted every year except for years ending in 2 or 7 when the Economic Census is conducted. The ASM provides statistics on employment, payroll, supplemental labor costs, cost of materials consumed, operating expenses, value of shipments, value added, fuels and energy used, and inventories. It uses a sample survey of approximately 50000 establishments with new samples selected at 5year intervals. The ASM data allows the examination of multiple factors (value added, payroll, energy use, and more) of manufacturing at a detailed subsector level. The Economic Census, used for years ending in 2 or 7 , is a survey of all employer establishments in the U.S. that has been taken as an integrated program at 5-year intervals since 1967. Both the ASM and the Economic Census use NAICS classification; however, prior to NAICS the Standard Industrial Classification system was used.

Table D.1 contains items from the Annual Survey of Manufactures. The color scheme matches that of the color scheme in the manufacturing supply chains in Tables D.2 through D.7 indicating that the items in the table were used to calculate the items in the schematic. For example, the items labeled in green in Table D.1 are used to calculate the items in green in Table D.2. Table D.2 contains the entirety of the manufacturing industry while D.3 through D.7 are a selection of sectors. The sectors were chosen based on being related to the medium- and high-technology manufacturing industry. 
Table D.1: Supply Chain Components

\begin{tabular}{|c|c|}
\hline AS M Data Item & Schematic name \\
\hline Number of employees & Payroll, Benefits, and employ ment \\
\hline Annual payroll & Payroll, Benefits, and employment \\
\hline Total fringe benefits & Payroll, Benefits, and employment \\
\hline \multicolumn{2}{|l|}{ Employer's cost for health insurance } \\
\hline \multicolumn{2}{|l|}{ Employer's cost for defined benefit pension plans } \\
\hline \multicolumn{2}{|l|}{ Employer's cost for defined contribution plans } \\
\hline \multicolumn{2}{|l|}{ Employer's cost for other fringe benefits } \\
\hline \multicolumn{2}{|l|}{ Production workers avg per year } \\
\hline \multicolumn{2}{|l|}{ Production workers hours $(1,000)$} \\
\hline \multicolumn{2}{|l|}{ Production workers wages } \\
\hline \multicolumn{2}{|l|}{ Total cost of materials } \\
\hline Materials, parts, containers, packaging, etc. used & Materials, parts, containers, packaging, etc used \\
\hline Cost of resales & Contract work and resales \\
\hline Contract work & Contract work and resales \\
\hline Cost of purchased fuels & Purchased fuels and electricity \\
\hline Purchased electricity & Purchased fuels and electricity \\
\hline \multicolumn{2}{|l|}{ Quantity of electricity purchased } \\
\hline \multicolumn{2}{|l|}{ Quantity of generated electricity } \\
\hline \multicolumn{2}{|l|}{ Quantity of electricity sold or transferred } \\
\hline Total value of shipments & Shipments \\
\hline \multicolumn{2}{|l|}{ Value of products shipments } \\
\hline \multicolumn{2}{|l|}{ Total miscellaneous receipts } \\
\hline \multicolumn{2}{|l|}{ Value of resales } \\
\hline \multicolumn{2}{|l|}{ Contract receipts } \\
\hline \multicolumn{2}{|l|}{ Other miscellaneous receipts } \\
\hline \multicolumn{2}{|l|}{ Value of interplant transfers } \\
\hline Value added & Value added \\
\hline \multicolumn{2}{|l|}{ Total EOY inventories } \\
\hline Finished goods inventories, EOY & Net Inventories Shipped \\
\hline Work-in-process inventories, EOY & Net Inventories Shipped \\
\hline \multicolumn{2}{|l|}{ Materials and supplies inventories, EOY } \\
\hline Total BOY inventories & \\
\hline Finished goods inventories, BOY & Net Inventories Shipped \\
\hline Work-in-process inventories, $\mathrm{BOY}$ & Net Inventories Shipped \\
\hline Materials and supplies inventories, BOY & \\
\hline Total capital expenditures (new and used) & \\
\hline Capital expenditures: buildings \& other structures (new and used) & Capital expenditures: buildings and other structures (new and used) \\
\hline Capital expenditures: machinery and equipment (new and used) & \\
\hline Capital expenditures: autos, trucks, etc. for highway use & Capital expenditures: machinery and equipment (new and used) \\
\hline Capital expenditures: computer and data processing equipment & Computer hardware, software, and other equipment \\
\hline Capital expenditures: all other machinery and equipment & Capital expenditures: machinery and equipment (new and used) \\
\hline Total depreciation & Depreciation \\
\hline Total rental payments & \\
\hline Buildings rentals & Capital expenditures: buildings and other structures (new and used): Rental \\
\hline Machinery rentals & Capital expenditures: machinery and equipment (new and used): Rental \\
\hline Total other expenses & \\
\hline Temporary staff and leased employee expenses & Other costs \\
\hline Expensed computer hardware and other equipment & Computer hardware, software, and other equipment \\
\hline Expensed purchases of software & Computer hardware, software, and other equipment \\
\hline Data processing and other purchased computer services & Professional, technical, and data services \\
\hline Communication services & Communication services \\
\hline Repair and maintenance services of buildings and/or machinery & Maintenance and repair \\
\hline Refuse removal (including hazardous waste) services & Refuse removal \\
\hline Advertising and promotional services & Other costs \\
\hline Purchased professional and technical services & Professional, technical, and data services \\
\hline Taxes and license fees & Other costs \\
\hline All other expenses & Other costs \\
\hline
\end{tabular}


Table D.2: Manufacturing Supply Chain

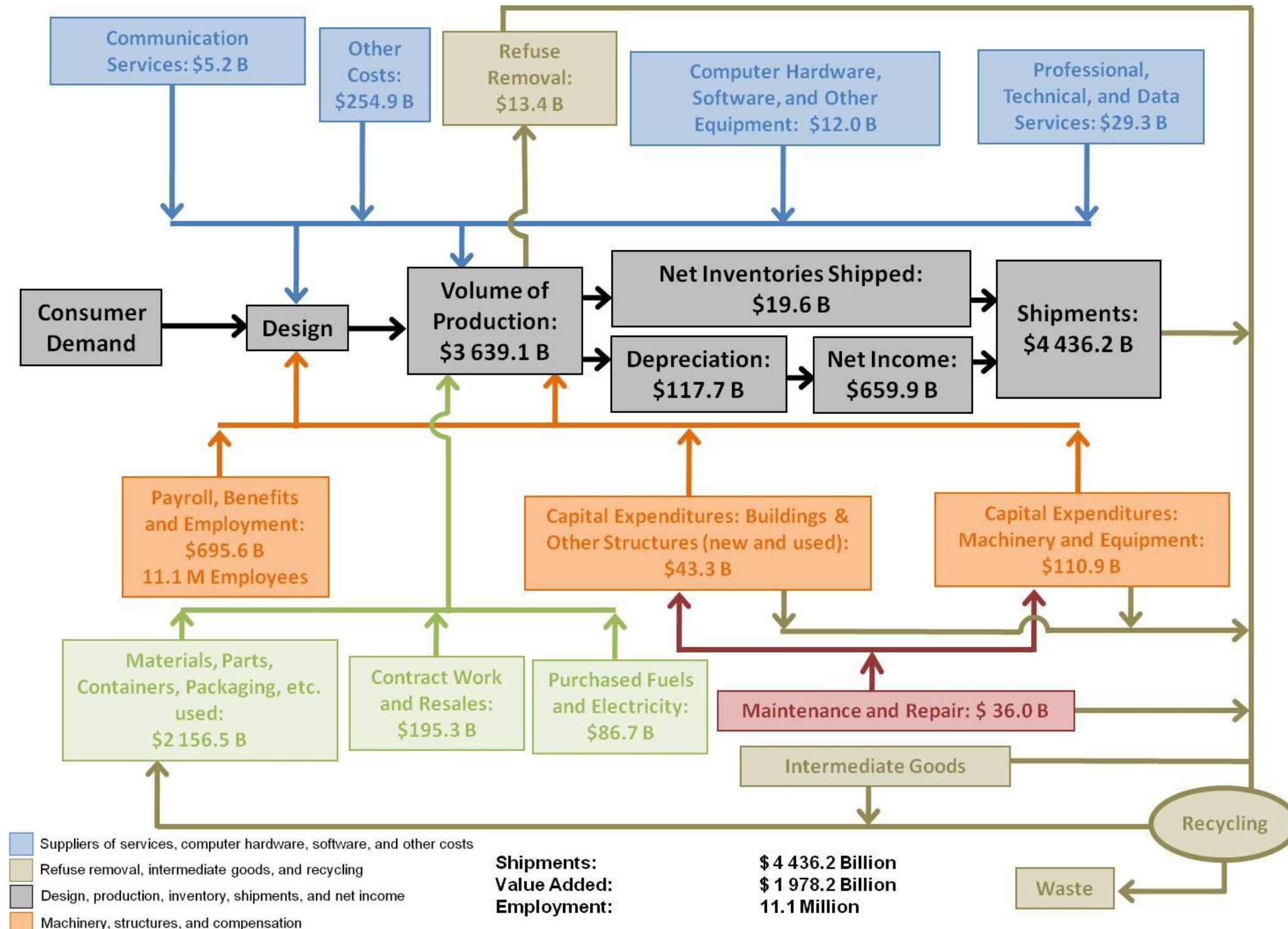


Table D.3: Manufacturing Supply Chain, NAICS 325: Chemical Manufacturing

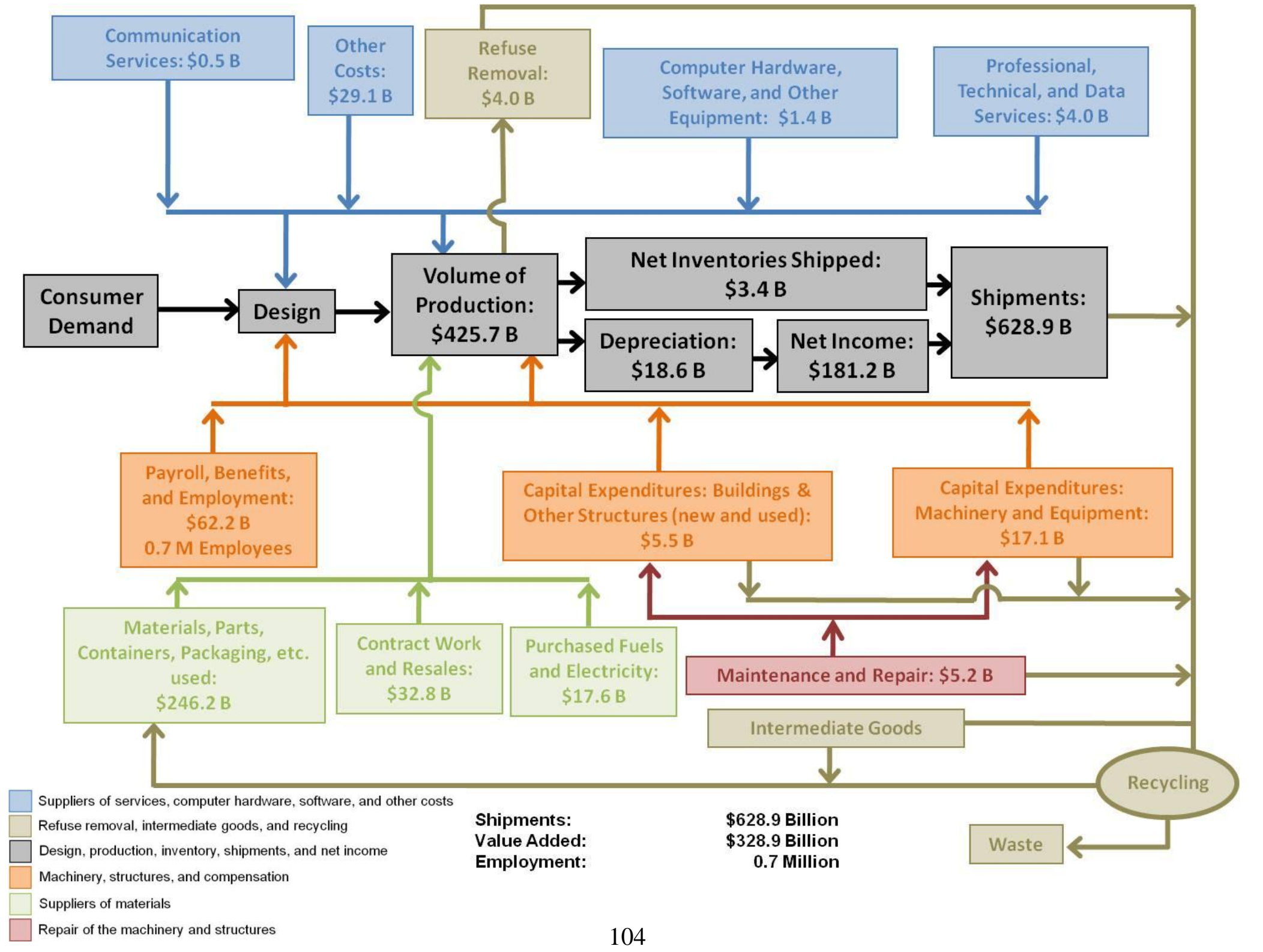


Table D.4: Manufacturing Supply Chain, NAICS 333: Machinery Manufacturing

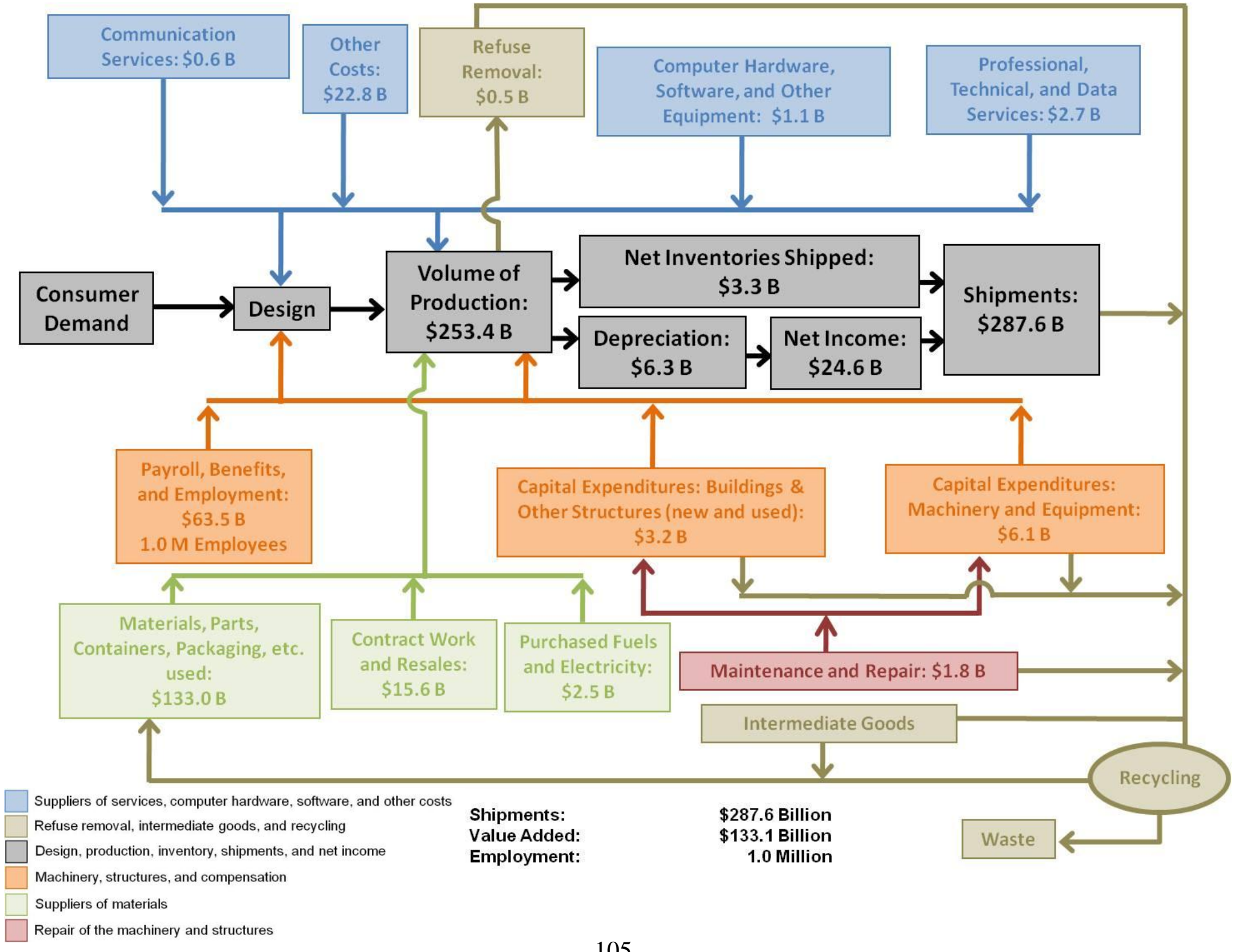


Table D.5: Manufacturing Supply Chain, NAICS 334: Computer and Electronic Product Manufacturing

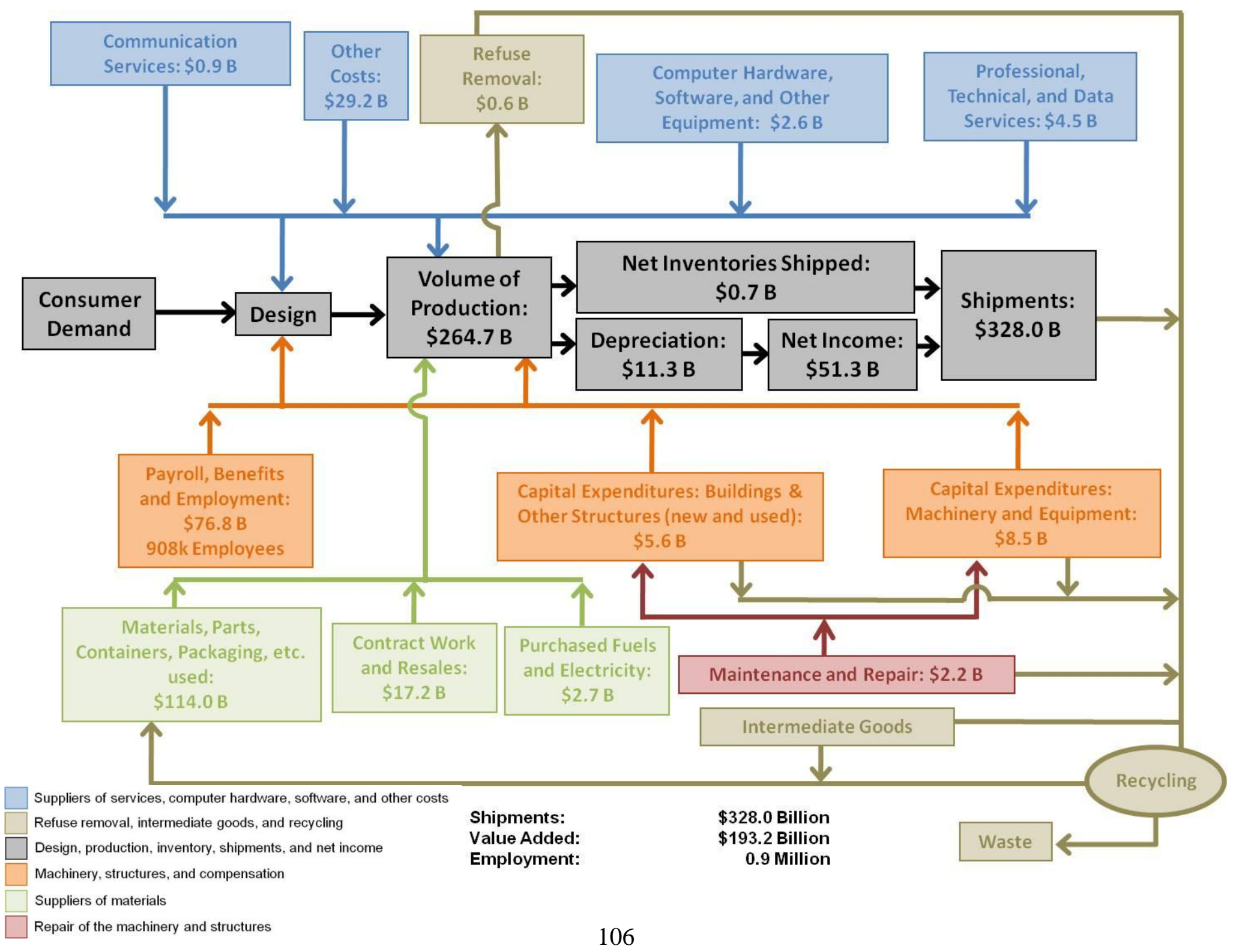


Table D.6: Manufacturing Supply Chain, NAICS 335: Electrical Equipment, Appliance, and Component Manufacturing

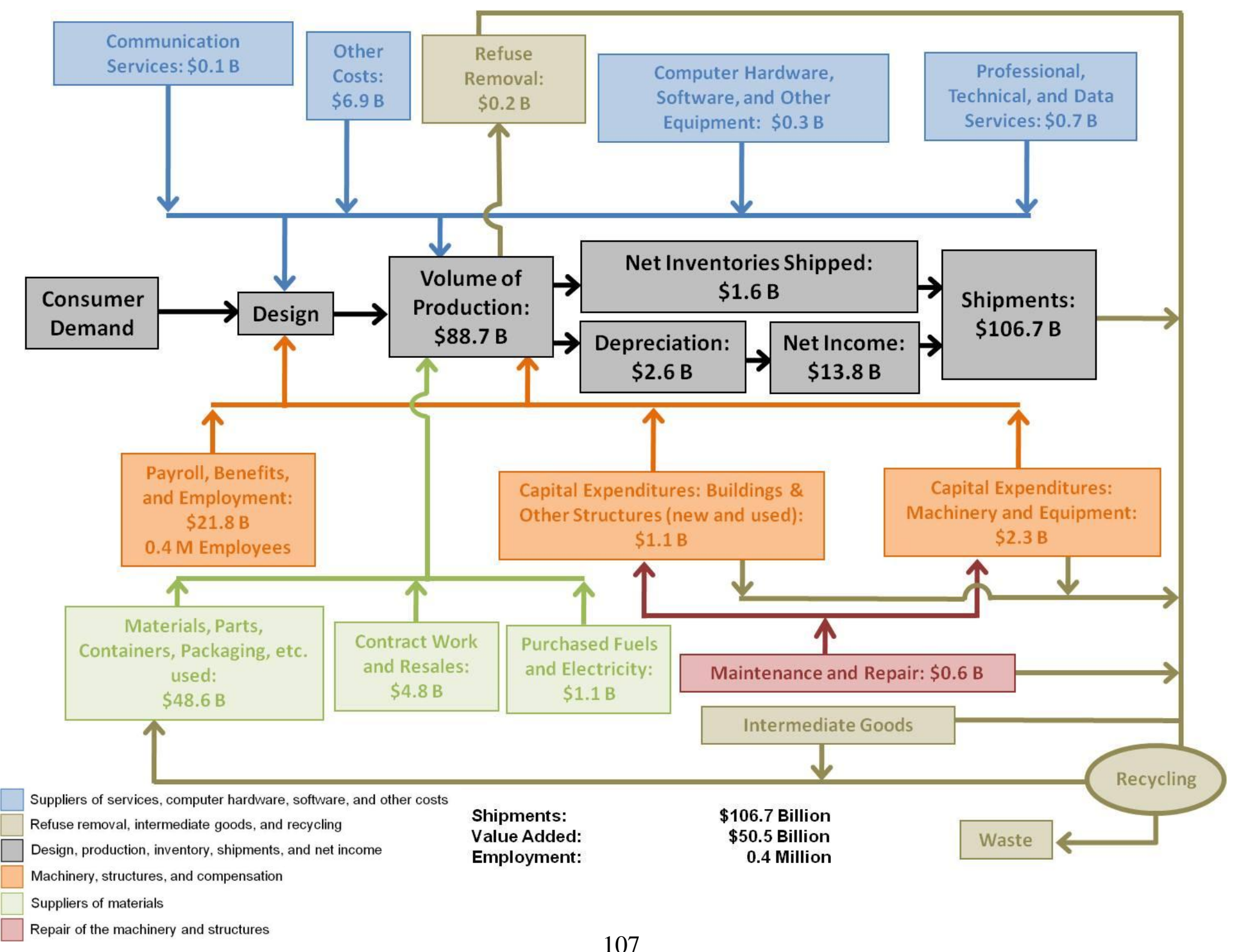


Table D.7: Manufacturing Supply Chain, NAICS 336: Transportation Equipment Manufacturing

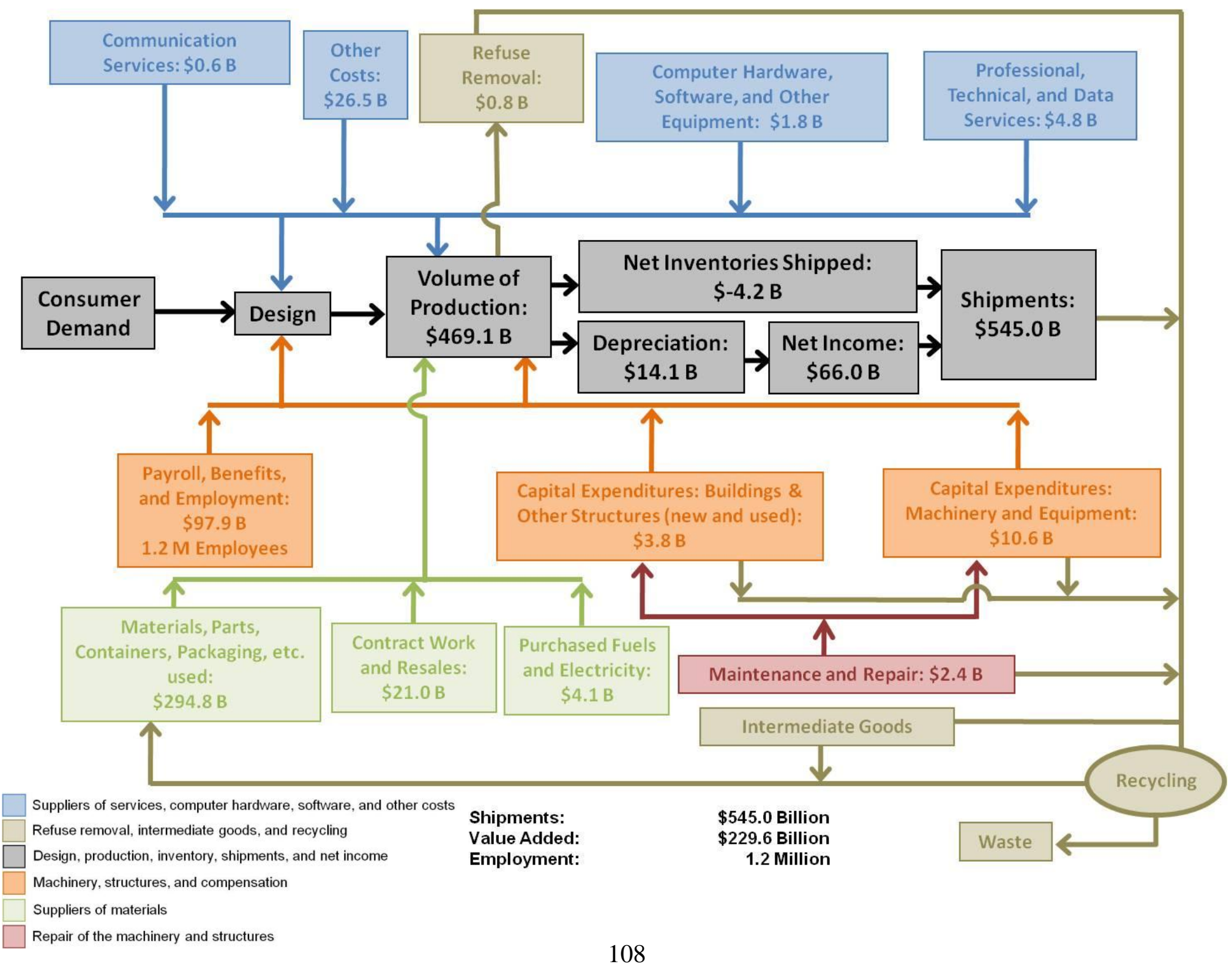




\section{Appendix E: Glossary of Terms}

Each dataset used in this report contains a set of terms to describe the boundaries of the data. A single term does not fully describe what the dataset includes and different organizations may define terms differently. Data from the Bureau of Economic Analysis, for example, defines value added differently than the Annual Survey of Manufactures. In order to understand these datasets completely, the terms describing them must be defined. Some datasets contain a significant number of inter-related variables, each being described with unique terms. The manufacturing supply chain in Table D.1, for instance, contains data from the Annual Survey of Manufactures. This dataset contains numerous terms, which need to be defined so the reader can understand the inter-relationships of the data and the meaning of the data. This section provides definitions for the various terms used in this report and in doing so outlines many of the inter-relationships in various datasets. Definitions of terms used by specific organizations are taken verbatim from the source and have the organization or data source name in parentheses. Terms specific to this report have the location in the report where they are used. The sources for definitions include the following:

Annual Survey of Manufactures (ASM).

<http://www.census.gov/manufacturing/asm/index.html>

Bureau of Economic Analysis (BEA). Horowitz, Karen J. and Mark A. Planting. (2009) Concepts and Methods of the U.S. Input-Output Accounts. Bureau of Economic Analysis. <http://www.bea.gov/papers/pdf/IOmanual_092906.pdf>

Organization for Economic Co-operation and Development (OECD). "StatExtracts." $<$ http://stats.oecd.org/Index.aspx>

United Nations Statistics Division (UNSD). "National Accounts Main Aggregates Database." <http://unstats.un.org/unsd/snaama/Introduction.asp>

U.S. Census Bureau. "Manufacturers' Shipments, Inventories, and Orders." <http://www.census.gov/manufacturing/m3/>

Advertising and promotional services (ASM): Included in the cost of selected advertising and promotional services are payments made to other companies for these services which were paid directly by the establishment. These include payments for printing, media coverage, and other services and materials. Excluded are the salaries paid to employees of this establishment for these services.

All other expenses (ASM): Included in the cost of all other expenses are payments made to other companies for services other than those listed elsewhere. These include, but are not limited to, items such as insurance, travel, training, transportation and office supplies. 
Annual payroll (ASM): This item includes the gross earnings of all employees on the payrolls of operating manufacturing establishments paid in the calendar year. Respondents are told they could follow the definition of payrolls used for calculating the federal withholding tax. It includes all forms of compensation, such as salaries, wages, commissions, dismissal pay, bonuses, vacation and sick leave pay, and compensation in kind, prior to such deductions as employees' social security contributions, withholding taxes, group insurance, union dues, and savings bonds. The total includes salaries of officers of corporations; it excludes payments to proprietors or partners of unincorporated concerns. Also excluded are payments to members of Armed Forces and pensioners carried on the active payrolls of manufacturing establishments.

The census definition of payrolls is identical to that recommended to all federal statistical agencies by the Office of Management and Budget. It should be noted that this definition does not include employers' social security contributions or other nonpayroll labor costs, such as employees' pension plans, group insurance premiums, and workers' compensation.

Note: Beginning with the 2006 ASM, for employment and related fields (payroll, production hours, benefits), respondents were asked to report only those full- and part-time employees whose payroll was reported on the IRS Form 941 filing for the Employer Identification Number (EIN) used by that manufacturing establishment. Other temporary workers and workers whose payroll was reported under a different company's EIN were reported elsewhere on the form. In 2002, these data constituted between 1 and $11 / 2 \%$ of the total for these fields. Comparisons with data prior to 2006 should be used with caution.

Buildings rentals (ASM): This item includes rental payments for the use of all items for which depreciation reserves would be maintained if they were owned by the establishment, e.g., structures and buildings, and production, office, and transportation equipment. Excluded are royalties and other payments for the use of intangibles and depletable assets and land rents where separable.

When an establishment of a multiestablishment company was charged rent by another part of the same company for the use of assets owned by the company, it was instructed to exclude that cost from rental payments.

If there were assets at an establishment rented from another company and the rents were paid centrally by the head office of the establishment, the company was instructed to report these rental payments as if they were paid directly by the establishment.

Capital expenditures: all other machinery and equipment (ASM): Represents the total new and used capital expenditures reported by establishments in operation and any known plants under construction. 
These data include expenditures for:

1. Permanent additions and major alterations to manufacturing and mining establishments.

2. New and used machinery and equipment used for replacement and additions to plant capacity, if they are of the type for which depreciation, depletion, or (for mining establishments) Office of Minerals Exploration accounts are ordinarily maintained. In addition, for mining establishments, these data include expenditures made during the year for development and exploration of mineral properties. For manufacturing establishments, these data are broken down into three types:

a. Automobiles, trucks, etc. for highway use. These include vehicles acquired under a lease-purchase agreement and exclude vehicles leased or normally designed to transport materials, property, or equipment on mining, construction, petroleum development, and similar projects. These vehicles are of such size or weight as to be normally restricted by state laws or regulations from operating on public highways. Also excluded are vehicles that are purchased by a company for highway use.

b. Computers and peripheral data processing equipment. This item includes all purchases of computers and related equipment.

c. All other expenditures for machinery and equipment excluding automobiles and computer equipment.

Capital expenditures include work done by contract, as well as by the establishment's own workforce.

These data exclude expenditures for land and mineral rights and cost of maintenance and repairs charged as current operating expenses.

Capital expenditures: autos, trucks, etc. for highway use (ASM): Represents the total new and used capital expenditures reported by establishments in operation and any known plants under construction.

These data include expenditures for:

1. Permanent additions and major alterations to manufacturing and mining establishments.

2. New and used machinery and equipment used for replacement and additions to plant capacity, if they are of the type for which depreciation, depletion, or (for mining establishments) Office of Minerals Exploration accounts are ordinarily maintained. In addition, for mining establishments, these data include expenditures made during the year for development and exploration of mineral properties. For manufacturing establishments, these data are broken down into three types:

a. Automobiles, trucks, etc. for highway use. These include vehicles acquired under a lease-purchase agreement and exclude vehicles leased or 
normally designed to transport materials, property, or equipment on mining, construction, petroleum development, and similar projects. These vehicles are of such size or weight as to be normally restricted by state laws or regulations from operating on public highways. Also excluded are vehicles that are purchased by a company for highway use.

b. Computers and peripheral data processing equipment. This item includes all purchases of computers and related equipment.

c. All other expenditures for machinery and equipment excluding automobiles and computer equipment.

Capital expenditures include work done by contract, as well as by the establishment's own workforce.

These data exclude expenditures for land and mineral rights and cost of maintenance and repairs charged as current operating expenses.

Capital expenditures: buildings and other structures (new and used) (ASM): Represents the total new and used capital expenditures reported by establishments in operation and any known plants under construction.

These data include expenditures for:

1. Permanent additions and major alterations to manufacturing and mining establishments.

2. New and used machinery and equipment used for replacement and additions to plant capacity, if they are of the type for which depreciation, depletion, or (for mining establishments) Office of Minerals Exploration accounts are ordinarily maintained. In addition, for mining establishments, these data include expenditures made during the year for development and exploration of mineral properties. For manufacturing establishments, these data are broken down into three types:

a. Automobiles, trucks, etc. for highway use. These include vehicles acquired under a lease-purchase agreement and exclude vehicles leased or normally designed to transport materials, property, or equipment on mining, construction, petroleum development, and similar projects. These vehicles are of such size or weight as to be normally restricted by state laws or regulations from operating on public highways. Also excluded are vehicles that are purchased by a company for highway use.

b. Computers and peripheral data processing equipment. This item includes all purchases of computers and related equipment.

c. All other expenditures for machinery and equipment excluding automobiles and computer equipment.

Capital expenditures include work done by contract, as well as by the establishment's own workforce. 
These data exclude expenditures for land and mineral rights and cost of maintenance and repairs charged as current operating expenses.

Capital expenditures: buildings and other structures (new and used) (Figure 4.5): This item is the sum of capital expenditures: buildings and other structures (new and used) and buildings rentals from the ASM.

Capital expenditures: computer and data processing equipment (ASM): Represents the total new and used capital expenditures reported by establishments in operation and any known plants under construction.

These data include expenditures for:

1. Permanent additions and major alterations to manufacturing and mining establishments.

2. New and used machinery and equipment used for replacement and additions to plant capacity, if they are of the type for which depreciation, depletion, or (for mining establishments) Office of Minerals Exploration accounts are ordinarily maintained. In addition, for mining establishments, these data include expenditures made during the year for development and exploration of mineral properties. For manufacturing establishments, these data are broken down into three types:

a. Automobiles, trucks, etc. for highway use. These include vehicles acquired under a lease-purchase agreement and exclude vehicles leased or normally designed to transport materials, property, or equipment on mining, construction, petroleum development, and similar projects. These vehicles are of such size or weight as to be normally restricted by state laws or regulations from operating on public highways. Also excluded are vehicles that are purchased by a company for highway use.

b. Computers and peripheral data processing equipment. This item includes all purchases of computers and related equipment.

c. All other expenditures for machinery and equipment excluding automobiles and computer equipment.

Capital expenditures include work done by contract, as well as by the establishment's own workforce.

These data exclude expenditures for land and mineral rights and cost of maintenance and repairs charged as current operating expenses.

Capital expenditures: machinery and equipment (new and used) (ASM):

Represents the total new and used capital expenditures reported by establishments in operation and any known plants under construction.

These data include expenditures for: 
1. Permanent additions and major alterations to manufacturing and mining establishments.

2. New and used machinery and equipment used for replacement and additions to plant capacity, if they are of the type for which depreciation, depletion, or (for mining establishments) Office of Minerals Exploration accounts are ordinarily maintained. In addition, for mining establishments, these data include expenditures made during the year for development and exploration of mineral properties. For manufacturing establishments, these data are broken down into three types:

a. Automobiles, trucks, etc. for highway use. These include vehicles acquired under a lease-purchase agreement and exclude vehicles leased or normally designed to transport materials, property, or equipment on mining, construction, petroleum development, and similar projects. These vehicles are of such size or weight as to be normally restricted by state laws or regulations from operating on public highways. Also excluded are vehicles that are purchased by a company for highway use.

b. Computers and peripheral data processing equipment. This item includes all purchases of computers and related equipment.

c. All other expenditures for machinery and equipment excluding automobiles and computer equipment.

Capital expenditures include work done by contract, as well as by the establishment's own workforce.

These data exclude expenditures for land and mineral rights and cost of maintenance and repairs charged as current operating expenses.

Capital expenditures: machinery and equipment (Figure 4.5): This item is the sum of the following items from the ASM: capital expenditures: autos, trucks, etc. for highway use, capital expenditures: all other machinery and equipment, and machinery rentals.

Capital Gains (Table 2.1): An increase in the value of a capital asset

Capital Goods (Table 2.1): Human made goods used in the production of other goods.

Commodity (BEA): A commodity is a product or service. It may be produced by one or by many industries. Commodity output represents the total output of the product or service, regardless of the industry that produced it.

If an industry and the commodity produced by the industry have the same name, the commodity is considered to be the primary product of that industry. Any other commodity produced by that industry is a secondary product of that industry. 
Communication services (ASM): Included in the cost of selected purchased services for communication are the actual expenses incurred or payable during the year for any type of communication. Such types of communication include telephone, data transmission, telegraph, Internet connectivity, fax, telex, photo transmission, paging, cellular telephone, online access and related services, etc.

Computer hardware, software, and other equipment (Figure 4.5): This item is the sum of Expensed computer hardware and other equipment, expensed purchases of software, and capital expenditures: computer and data processing equipment from the ASM.

Contract receipts (ASM): Miscellaneous receipts represent receipts from activities of the establishment other than the manufacturing of products from its own materials. Service activities such as installation, repair, and training are miscellaneous receipts. Assembly of products from materials owned by others and the sale of products bought and resold without further value added are other examples of miscellaneous receipts. Miscellaneous receipts are collected using the following categories:

1. Reported contract work - receipts for work or services that a plant performed for others on their materials.

2. Value of resales - sales of products bought and sold without further manufacture, processing, or assembly.

3. Other miscellaneous receipts - such as repair work, installation, sales of scrap, etc.

Contract work (ASM): This term refers to direct charges actually paid or payable for items consumed or put into production during the year, including freight charges and other direct charges incurred by the establishment in acquiring these materials. It includes the cost of materials or fuel consumed, whether purchased by the individual establishment from other companies, transferred to it from other establishments of the same company, or withdrawn from inventory during the year.

Included in this item are:

1. Cost of parts, components, containers, etc. Includes all raw materials, semifinished goods, parts, containers, scrap, and supplies put into production or used as operating supplies and for repair and maintenance during the year.

2. Cost of products bought and sold in the same condition.

3. Cost of fuels consumed for heat and power. Includes the cost of materials or fuel consumed, whether purchased by the individual establishment from other companies, transferred to it from other establishments of the same company, or withdrawn from inventory during the year.

4. Cost of purchased electricity. The cost of purchased electric energy represents the amount actually used during the year for heat and power. In addition, information was collected on the quantity of electric energy generated by the establishment 
and the quantity of electric energy sold or transferred to other plants of the same company.

5. Cost of contract work. This term applies to work done by others on materials furnished by the manufacturing establishment. The actual cost of the material is to be reported on the cost of materials, parts, and containers line of this item. The term "contract work" refers to the fee a company pays to another company to perform a service.

Contract work and resales (Figure 4.5): This item is the sum of the cost of resales and contract work from the ASM.

Cost of purchased fuels (ASM): This term refers to direct charges actually paid or payable for items consumed or put into production during the year, including freight charges and other direct charges incurred by the establishment in acquiring these materials. It includes the cost of materials or fuel consumed, whether purchased by the individual establishment from other companies, transferred to it from other establishments of the same company, or withdrawn from inventory during the year.

Included in this item are:

1. Cost of parts, components, containers, etc. Includes all raw materials, semifinished goods, parts, containers, scrap, and supplies put into production or used as operating supplies and for repair and maintenance during the year.

2. Cost of products bought and sold in the same condition.

3. Cost of fuels consumed for heat and power. Includes the cost of materials or fuel consumed, whether purchased by the individual establishment from other companies, transferred to it from other establishments of the same company, or withdrawn from inventory during the year.

4. Cost of purchased electricity. The cost of purchased electric energy represents the amount actually used during the year for heat and power. In addition, information was collected on the quantity of electric energy generated by the establishment and the quantity of electric energy sold or transferred to other plants of the same company.

5. Cost of contract work. This term applies to work done by others on materials furnished by the manufacturing establishment. The actual cost of the material is to be reported on the cost of materials, parts, and containers line of this item. The term "contract work" refers to the fee a company pays to another company to perform a service.

Cost of resales (ASM): This term refers to direct charges actually paid or payable for items consumed or put into production during the year, including freight charges and other direct charges incurred by the establishment in acquiring these materials. It includes the cost of materials or fuel consumed, whether purchased by the individual establishment from other companies, transferred to it from other establishments of the same company, or withdrawn from inventory during the year. 
Included in this item are:

1. Cost of parts, components, containers, etc. Includes all raw materials, semifinished goods, parts, containers, scrap, and supplies put into production or used as operating supplies and for repair and maintenance during the year.

2. Cost of products bought and sold in the same condition.

3. Cost of fuels consumed for heat and power. Includes the cost of materials or fuel consumed, whether purchased by the individual establishment from other companies, transferred to it from other establishments of the same company, or withdrawn from inventory during the year.

4. Cost of purchased electricity. The cost of purchased electric energy represents the amount actually used during the year for heat and power. In addition, information was collected on the quantity of electric energy generated by the establishment and the quantity of electric energy sold or transferred to other plants of the same company.

5. Cost of contract work. This term applies to work done by others on materials furnished by the manufacturing establishment. The actual cost of the material is to be reported on the cost of materials, parts, and containers line of this item. The term "contract work" refers to the fee a company pays to another company to perform a service.

Data processing and other purchased computer services (ASM): Included in the cost of selected data processing and other purchased computer services are purchases of computer facilities management services, computer input preparation, data storage, computer time rental, optical scanning services, and other computerrelated advice and services, including training. Excluded are services such as expensed integrated systems, repair and maintenance of computer equipment, payroll processing and credit card transaction fees, and expenses for telecommunication services (e.g., Internet connectivity, telephone).

Economic Success (Table 2.1): A constant and suitable magnitude of production resulting in competitive benefits (profits, capital gains, income, and product utilization) for an industry's stakeholders.

Employer's cost for health insurance (ASM): This item is the employer's costs for social security tax, unemployment tax, workers' compensation insurance, state disability insurance pension plans, stock purchase plans, union-negotiated benefits, life insurance premiums, and insurance premiums on hospital and medical plans for employees. Also included are the employer's costs for benefits to individual employees such as stock purchase plans, deferred profit-sharing plans, and defined benefit and defined contribution retirement plans. They exclude such items as company-operated cafeterias, in-plant medical services, free parking lots, discounts on employee purchases, and uniforms and work clothing for employees.

These figures represent the total amount of employer-paid benefits for all categories shown, and are inclusive of payments made on behalf of individuals that may not be 
included in the current payroll values . Consequently, for some manufacturing industries, payroll and benefits values may not move in tandem when compared to prior year tabulation totals.

Note: Beginning with the 2006 ASM, for employment and related fields (payroll, production hours, benefits), respondents were asked to report only those full- and part-time employees whose payroll was reported on the IRS Form 941 filing for the Employer Identification Number (EIN) used by that manufacturing establishment. Other temporary workers and workers whose payroll was reported under a different company's EIN were reported elsewhere on the form. In 2002, these data constituted between 1 and $11 / 2 \%$ of the total for these fields. Comparisons with data prior to 2006 should be used with caution.

Employer's cost for defined benefit pension plans (ASM): This item is the employer's costs for social security tax, unemployment tax, workers' compensation insurance, state disability insurance pension plans, stock purchase plans, unionnegotiated benefits, life insurance premiums, and insurance premiums on hospital and medical plans for employees. Also included are the employer's costs for benefits to individual employees such as stock purchase plans, deferred profit-sharing plans, and defined benefit and defined contribution retirement plans. They exclude such items as company-operated cafeterias, in-plant medical services, free parking lots, discounts on employee purchases, and uniforms and work clothing for employees.

These figures represent the total amount of employer-paid benefits for all categories shown, and are inclusive of payments made on behalf of individuals that may not be included in the current payroll values . Consequently, for some manufacturing industries, payroll and benefits values may not move in tandem when compared to prior year tabulation totals.

Note: Beginning with the 2006 ASM, for employment and related fields (payroll, production hours, benefits), respondents were asked to report only those full- and part-time employees whose payroll was reported on the IRS Form 941 filing for the Employer Identification Number (EIN) used by that manufacturing establishment. Other temporary workers and workers whose payroll was reported under a different company's EIN were reported elsewhere on the form. In 2002, these data constituted between 1 and $11 / 2 \%$ of the total for these fields. Comparisons with data prior to 2006 should be used with caution.

Employer's cost for defined contribution plans (ASM): This item is the employer's costs for social security tax, unemployment tax, workers' compensation insurance, state disability insurance pension plans, stock purchase plans, unionnegotiated benefits, life insurance premiums, and insurance premiums on hospital and medical plans for employees. Also included are the employer's costs for benefits to individual employees such as stock purchase plans, deferred profit-sharing plans, and defined benefit and defined contribution retirement plans. They exclude such 
items as company-operated cafeterias, in-plant medical services, free parking lots, discounts on employee purchases, and uniforms and work clothing for employees.

These figures represent the total amount of employer-paid benefits for all categories shown, and are inclusive of payments made on behalf of individuals that may not be included in the current payroll values . Consequently, for some manufacturing industries, payroll and benefits values may not move in tandem when compared to prior year tabulation totals.

Note: Beginning with the 2006 ASM, for employment and related fields (payroll, production hours, benefits), respondents were asked to report only those full- and part-time employees whose payroll was reported on the IRS Form 941 filing for the Employer Identification Number (EIN) used by that manufacturing establishment. Other temporary workers and workers whose payroll was reported under a different company's EIN were reported elsewhere on the form. In 2002, these data constituted between 1 and $11 / 2 \%$ of the total for these fields. Comparisons with data prior to 2006 should be used with caution.

Employer's cost for other fringe benefits (ASM): This item is the employer's costs for social security tax, unemployment tax, workers' compensation insurance, state disability insurance pension plans, stock purchase plans, union-negotiated benefits, life insurance premiums, and insurance premiums on hospital and medical plans for employees. Also included are the employer's costs for benefits to individual employees such as stock purchase plans, deferred profit-sharing plans, and defined benefit and defined contribution retirement plans. They exclude such items as company-operated cafeterias, in-plant medical services, free parking lots, discounts on employee purchases, and uniforms and work clothing for employees.

These figures represent the total amount of employer-paid benefits for all categories shown, and are inclusive of payments made on behalf of individuals that may not be included in the current payroll values . Consequently, for some manufacturing industries, payroll and benefits values may not move in tandem when compared to prior year tabulation totals.

Note: Beginning with the 2006 ASM, for employment and related fields (payroll, production hours, benefits), respondents were asked to report only those full- and part-time employees whose payroll was reported on the IRS Form 941 filing for the Employer Identification Number (EIN) used by that manufacturing establishment. Other temporary workers and workers whose payroll was reported under a different company's EIN were reported elsewhere on the form. In 2002, these data constituted between 1 and $11 / 2 \%$ of the total for these fields. Comparisons with data prior to 2006 should be used with caution.

Establishment (BEA): An economic unit — business or industrial — at a single physical location where business is conducted or where services or industrial operations are performed. Examples include a factory, mill, store, hotel, movie 
theater, mine, farm, ranch, bank, railroad depot, airline terminal, sales office, warehouse, or central administrative office. One or more establishments make up an enterprise or a company. However, a single establishment may be comprised of subunits, departments, or divisions. In the industry classification systems-SIC and NAICS - the establishment is the basic unit for collecting many types of economic information.

Expensed computer hardware and other equipment (ASM): Included in the cost of selected expensed computer hardware and other equipment are actual expenses incurred or payable during the year for this item. Purchases of copiers, fax machines, telephones, shop and lab equipment, CPUs, and monitors are all included. Excluded are services provided by other establishments of the same company (such as software and data processing services).

Expensed purchases of software (ASM): Included in the cost of selected expensed purchases of software are actual expenses incurred or payable during the year for this item. Purchases of software developed or customized by others, web-design services and purchases, licensing agreements, upgrades of software, and maintenance fees related to software upgrades and alterations are all included.

Financial Capital (Table 2.1): Funds provided by investors to purchase real capital equipment for production.

Final Product Utilization (Table 2.1): The utility gained from the end user of a product.

Finished goods inventories, BOY (ASM): Respondents were asked to report their beginning of year and end of year inventories at cost or market. Effective with the 1982 Economic Census, this change to a uniform instruction for reporting inventories was introduced for all sector reports. Prior to 1982, respondents were permitted to value inventories using any generally accepted accounting method (FIFO, LIFO, or market, to name a few). Beginning in 1982, LIFO users were asked to first report inventory values prior to the LIFO adjustment and then to report the LIFO reserve and the LIFO value after adjustment for the reserve.

Inventory data by stage of fabrication

Total inventories and three detailed components were collected:

1. Finished goods

2. Work-in-process

3. Materials, supplies, fuels, etc.

Materials inventories refer to goods that are raw inputs to the manufacturing process, and that will be substantially altered to produce an establishment's output. Work-in-process inventories refer to goods that have been substantially transformed 
in the manufacturing process, but that are not yet the final output of the establishment. Finished goods are goods that represent the final output of the establishment, but that are still within ownership of the establishment.

When using inventory data by stage of fabrication for "all industries" and at the three-digit subsector level, it should be noted that an item treated as a finished product by an establishment in one industry may be reported as a raw material by an establishment in a different industry. For example, the finished product inventories of a steel mill would be reported as raw materials by a stamping plant. Such differences are present in the inventory figures by stage of fabrication shown for all publication levels.

Finished goods inventories, EOY (ASM): Respondents were asked to report their beginning of year and end of year inventories at cost or market. Effective with the 1982 Economic Census, this change to a uniform instruction for reporting inventories was introduced for all sector reports. Prior to 1982, respondents were permitted to value inventories using any generally accepted accounting method (FIFO, LIFO, or market, to name a few). Beginning in 1982, LIFO users were asked to first report inventory values prior to the LIFO adjustment and then to report the LIFO reserve and the LIFO value after adjustment for the reserve.

\section{Inventory data by stage of fabrication}

Total inventories and three detailed components were collected:

1. Finished goods

2. Work-in-process

3. Materials, supplies, fuels, etc.

Materials inventories refer to goods that are raw inputs to the manufacturing process, and that will be substantially altered to produce an establishment's output. Work-in-process inventories refer to goods that have been substantially transformed in the manufacturing process, but that are not yet the final output of the establishment. Finished goods are goods that represent the final output of the establishment, but that are still within ownership of the establishment.

When using inventory data by stage of fabrication for "all industries" and at the threedigit subsector level, it should be noted that an item treated as a finished product by an establishment in one industry may be reported as a raw material by an establishment in a different industry. For example, the finished product inventories of a steel mill would be reported as raw materials by a stamping plant. Such differences are present in the inventory figures by stage of fabrication shown for all publication levels.

Final use (BEA): The consumption of the goods and services that are produced and distributed in the economy. In the I-O accounts, final-use transactions consist of the transactions that make up the final-expenditure components of GDP: Personal 
consumption expenditures; private fixed investment; change in private inventories; exports of goods and services; imports of goods and services; and Federal, state, and local government consumption expenditures and gross investment (including investment by government enterprises).

Gross Domestic Product (BEA): The market value of the goods and services produced by labor and property located within the borders of the United States. In 1991, GDP replaced gross national product (GNP) as the featured measure of U.S. production.

Gross operating surplus (Table 3.5 and Table 3.10): Gross output less a subset of costs (i.e., intermediate expenditures, compensation, and taxes less subsidies). It is similar to profit with the exception that it does not take into account the depreciation of capital.

Gross operating surplus (BEA): It is a profits-like measure that includes proprietors' income, corporate profits, net interest, business transfer payments, etc. GOS can be calculated as gross output less (1) intermediate inputs, (2) employee compensation, and (3) "taxes on production and imports less subsidies."

Intermediate Inputs (BEA): Purchases of goods and services - such as energy, materials, and purchased services - that are used for the production of other goods and services rather than for final consumption. These inputs are sometimes referred to as current-account expenditures. They do not include any capital-account purchases nor do they include the inputs from the primary factors of production (capital and labor) that are components of value added.

Labor (Table 2.1): Human effort used in production, which includes technical and marketing expertise.

Land (Table 2.1):Naturally-occurring goods such as water, air, soil, mineral, and flora used in the formation of products.

Machinery rentals (ASM): This item includes rental payments for the use of all items for which depreciation reserves would be maintained if they were owned by the establishment, e.g., structures and buildings, and production, office, and transportation equipment. Excluded are royalties and other payments for the use of intangibles and depletable assets and land rents where separable.

When an establishment of a multiestablishment company was charged rent by another part of the same company for the use of assets owned by the company, it was instructed to exclude that cost from rental payments.

If there were assets at an establishment rented from another company and the rents were paid centrally by the head office of the establishment, the company was instructed to report these rental payments as if they were paid directly by the establishment. 
Maintenance and repair (Figure 4.5): See repair and maintenance services of buildings and/or machinery

Make table (BEA): Matrix that shows the value in producers' prices of each commodity produced by each industry. The entries in a row represent the dollar value of commodities produced by the industry at the beginning of the row. The entries in a column represent the dollar value of production by each industry of the commodity at the top of the column. It is one of the two primary tables in the I-O accounts. The make table, together with the use table, is used to derive the I-O total requirements tables.

Materials and supplies inventories, EOY (ASM): Respondents were asked to report their beginning of year and end of year inventories at cost or market. Effective with the 1982 Economic Census, this change to a uniform instruction for reporting inventories was introduced for all sector reports. Prior to 1982, respondents were permitted to value inventories using any generally accepted accounting method (FIFO, LIFO, or market, to name a few). Beginning in 1982, LIFO users were asked to first report inventory values prior to the LIFO adjustment and then to report the LIFO reserve and the LIFO value after adjustment for the reserve.

Inventory data by stage of fabrication

Total inventories and three detailed components were collected:

1. Finished goods

2. Work-in-process

3. Materials, supplies, fuels, etc.

Materials inventories refer to goods that are raw inputs to the manufacturing process, and that will be substantially altered to produce an establishment's output. Work-in-process inventories refer to goods that have been substantially transformed in the manufacturing process, but that are not yet the final output of the establishment. Finished goods are goods that represent the final output of the establishment, but that are still within ownership of the establishment.

When using inventory data by stage of fabrication for "all industries" and at the three-digit subsector level, it should be noted that an item treated as a finished product by an establishment in one industry may be reported as a raw material by an establishment in a different industry. For example, the finished product inventories of a steel mill would be reported as raw materials by a stamping plant. Such differences are present in the inventory figures by stage of fabrication shown for all publication levels.

Materials and supplies inventories, BOY (ASM): Respondents were asked to report their beginning of year and end of year inventories at cost or market. 
Effective with the 1982 Economic Census, this change to a uniform instruction for reporting inventories was introduced for all sector reports. Prior to 1982, respondents were permitted to value inventories using any generally accepted accounting method (FIFO, LIFO, or market, to name a few). Beginning in 1982, LIFO users were asked to first report inventory values prior to the LIFO adjustment and then to report the LIFO reserve and the LIFO value after adjustment for the reserve.

Inventory data by stage of fabrication

Total inventories and three detailed components were collected:

1. Finished goods

2. Work-in-process

3. Materials, supplies, fuels, etc.

Materials inventories refer to goods that are raw inputs to the manufacturing process, and that will be substantially altered to produce an establishment's output. Work-in-process inventories refer to goods that have been substantially transformed in the manufacturing process, but that are not yet the final output of the establishment. Finished goods are goods that represent the final output of the establishment, but that are still within ownership of the establishment.

When using inventory data by stage of fabrication for "all industries" and at the three-digit subsector level, it should be noted that an item treated as a finished product by an establishment in one industry may be reported as a raw material by an establishment in a different industry. For example, the finished product inventories of a steel mill would be reported as raw materials by a stamping plant. Such differences are present in the inventory figures by stage of fabrication shown for all publication levels.

Materials, parts, containers, packaging, etc. used (ASM): This term refers to direct charges actually paid or payable for items consumed or put into production during the year, including freight charges and other direct charges incurred by the establishment in acquiring these materials. It includes the cost of materials or fuel consumed, whether purchased by the individual establishment from other companies, transferred to it from other establishments of the same company, or withdrawn from inventory during the year.

Included in this item are:

1. Cost of parts, components, containers, etc. Includes all raw materials, semifinished goods, parts, containers, scrap, and supplies put into production or used as operating supplies and for repair and maintenance during the year.

2. Cost of products bought and sold in the same condition. 
3. Cost of fuels consumed for heat and power. Includes the cost of materials or fuel consumed, whether purchased by the individual establishment from other companies, transferred to it from other establishments of the same company, or withdrawn from inventory during the year.

4. Cost of purchased electricity. The cost of purchased electric energy represents the amount actually used during the year for heat and power. In addition, information was collected on the quantity of electric energy generated by the establishment and the quantity of electric energy sold or transferred to other plants of the same company.

5. Cost of contract work. This term applies to work done by others on materials furnished by the manufacturing establishment. The actual cost of the material is to be reported on the cost of materials, parts, and containers line of this item. The term "contract work" refers to the fee a company pays to another company to perform a service.

Net Income (Manufacturing Supply Chain and Table 4.1): The total value of shipments less all costs (communication services; other costs; refuse removal; computer hardware, software, and other equipment; professional, technical, and data services, payroll and benefits; capital expenditures; materials, parts, containers, packaging, etc used; contract work and resales; purchased fuels and electicity; and maintenance and repair) and depreciation.

Net Inventories Shipped (Manufacturing Supply Chain and Table 4.1): The total beginning of year (BOY) inventories (finished goods and work-in-process inventories) less the total end of year (EOY) inventories (finished goods and workin-process inventories).

Other Costs (Figure 4.5): The sum of Taxes and license fees, advertising and promotional services, temporary staff and leased employee expenses, and all other expenses from the ASM.

Other misc. receipts (ASM): Miscellaneous receipts represent receipts from activities of the establishment other than the manufacturing of products from its own materials. Service activities such as installation, repair, and training are miscellaneous receipts. Assembly of products from materials owned by others and the sale of products bought and resold without further value added are other examples of miscellaneous receipts. Miscellaneous receipts are collected using the following categories:

1. Reported contract work - receipts for work or services that a plant performed for others on their materials.

2. Value of resales - sales of products bought and sold without further manufacture, processing, or assembly.

3. Other miscellaneous receipts - such as repair work, installation, sales of scrap, etc. 
Payroll, Benefits, and Employment (Figure 4.5): This is the sum of annual payroll and total fringe benefits from the ASM shown with the number of employees.

Production workers wages (ASM): "Production workers" refers to workers up through the line-supervisor level engaged in fabricating, processing, assembling, inspecting, receiving, packing, warehoursing, shipping (but not delivering) maintenance, repair, janitorial, guard services, product development, auxiliary production for the plant's own use (e.g., power plant workers), recordkeeping, and other closely associated services (including truck drivers delivering ready-mixed concrete).

"Payroll" includes the gross earnings of all employees on the payrolls of operating manufacturing establishments paid in the calendar year. Respondents were told they could follow the definition of payrolls used for calculating the federal withholding tax. It includes all forms of compensation, such as salaries, wages, commissions, dismissal pay, bonuses, vacation and sick leave pay, and compensation in kind, prior to such deductions as employees' social security contributions, withholding taxes, group insurance, union dues, and savings bonds. The total includes salaries of officers of corporations; it excludes payments to proprietors or partners of unincorporated concerns. Also excluded are payments to members of Armed Forces and pensioners carried on the active payrolls of manufacturing establishments.

The census definition of payrolls is identical to that recommended to all federal statistical agencies by the Office of Management and Budget. It should be noted that this definition does not include employers' social security contributions or other nonpayroll labor costs, such as employees' pension plans, group insurance premiums, and workers' compensation.

Note: Beginning with the 2006 ASM, for employment and related fields (payroll, production hours, benefits), respondents were asked to report only those full- and parttime employees whose payroll was reported on the IRS Form 941 filing for the Employer Identification Number (EIN) used by that manufacturing establishment. Other temporary workers and workers whose payroll was reported under a different company's EIN were reported elsewhere on the form. In 2002, these data constituted between 1 and 1 1/2\% of the total for these fields. Comparisons with data prior to 2006 should be used with caution.

Professional, Technical, and Data Services (Figure 4.5): This is the sum of data processing and other purchased computer services and purchased professional and technical services from the ASM.

Profit from Fees (Table 2.1): The financial benefit realized when revenues exceed costs and taxes for a service.

Profit from Markup (Table 2.1): The difference between the cost of a good and its selling price. 
Profit from Sales (Table 2.1): The financial benefit realized when revenues exceed costs and taxes for a product.

Purchased electricity (ASM): This term refers to direct charges actually paid or payable for items consumed or put into production during the year, including freight charges and other direct charges incurred by the establishment in acquiring these materials. It includes the cost of materials or fuel consumed, whether purchased by the individual establishment from other companies, transferred to it from other establishments of the same company, or withdrawn from inventory during the year.

Included in this item are:

1. Cost of parts, components, containers, etc. Includes all raw materials, semifinished goods, parts, containers, scrap, and supplies put into production or used as operating supplies and for repair and maintenance during the year.

2. Cost of products bought and sold in the same condition.

3. Cost of fuels consumed for heat and power. Includes the cost of materials or fuel consumed, whether purchased by the individual establishment from other companies, transferred to it from other establishments of the same company, or withdrawn from inventory during the year.

4. Cost of purchased electricity. The cost of purchased electric energy represents the amount actually used during the year for heat and power. In addition, information was collected on the quantity of electric energy generated by the establishment and the quantity of electric energy sold or transferred to other plants of the same company.

5. Cost of contract work. This term applies to work done by others on materials furnished by the manufacturing establishment. The actual cost of the material is to be reported on the cost of materials, parts, and containers line of this item. The term "contract work" refers to the fee a company pays to another company to perform a service.

Purchased fuels and electricity (Figure 4.5): This item is the sum of the cost of purchased fuels and purchased electricity from the ASM.

Purchased professional and technical services (ASM): Included in the cost of selected purchased professional and technical services are payments made to other companies for these services which were paid directly by the establishment. These include payments for management consulting, accounting, auditing, bookkeeping, legal, actuarial, payroll processing, architectural, engineering, and other professional services. Excluded are the salaries paid to employees of this establishment for these services.

Purchasing Price (Table 2.1): Market value of goods sold 
Redefinition (BEA): Redefinitions, one of the three methods for handling secondary products, are made as part of the preparation of the supplementary I-O make and use tables.

Redefinitions are made when an industry's production of a secondary product has very different inputs ("recipe") than those for the production of its primary product. In such a case, the secondary product (output and inputs) is moved ("redefined") from the industry in which the output occurs to the industry in which the product is primary. For example, the output and associated inputs for restaurants located in hotels are moved from the hotels and lodging places industry to the eating and drinking places industry.

Redefinitions do not affect the definition of the commodity or the measurement of commodity output, which consists of all of the output of that commodity wherever it's produced. However, redefinitions do affect industry output.

Refuse removal (including hazardous waste) services (ASM): Included in the cost of selected purchased refuse removal services are payments made to other companies for these services which were paid directly by the establishment, including costs for hazardous waste removal or treatment. Excluded are all costs included in rental payments or as capital expenditures and the salaries paid to employees of the establishment for these services.

\section{Repair and maintenance services of buildings and/or machinery (ASM):} Included in the cost of selected purchased services for the repair and maintenance services of buildings and/or machinery are payments made for all maintenance and repair work on buildings and equipment. Payments made to other establishments of the same company and for repair and maintenance of any leased property also are included. Excluded from this item are extensive repairs or reconstruction that was capitalized, which is considered capital expenditures; costs incurred directly by the establishment in using its own work force to perform repairs and maintenance work; and repairs and maintenance provided by the building or machinery owner as part of the rental contract.

Requirements table (BEA): There are four I-O requirements tables: Commodityby-industry direct requirements, commodity-by-commodity total requirements, industry-by-commodity total requirements, and industry-by-industry total requirements.

Secondary product (BEA): A good or service that is produced by an industry in addition to its primary product. Secondary products are the primary product of another industry. Secondary products in the I-O accounts are termed redefinitions, reclassifications, and other secondary products.

Shipments (Manufacturers' Shipments, Inventories, and Orders Survey): Manufacturers' shipments measure the dollar value of products sold by 
manufacturing establishments and are based on net selling values, f.o.b. (free on board) plant, after discounts and allowances are excluded. Freight charges and excise taxes are excluded. Where the products of an industry are customarily delivered to distributors or consumers by the manufacturing establishment (such as in certain foods industries - fluid milk, bakery, soft drinks), the value is based on delivered price rather than f.o.b. plant price. Multi-industry companies report value information for each industry category as if it were a separate economic unit. Thus, products transferred from one plant to another are valued at their full economic value.

Standard make and use tables (BEA): The featured tables in the 1997 benchmark I-O, these tables are based on NAICS. They are constructed before the redefinitions of selected secondary products. (In the 1992 I-O accounts, these make and use tables were referred to as "alternative" tables.)

Supplementary make and use tables (BEA): A second set of tables in the 1997 benchmark I-O, these tables are derived from the standard make and use tables. The estimates in the supplementary make and use tables are after the redefinitions of selected secondary products. (In the 1992 I-O accounts, these make and use tables and the requirements tables were referred to as "traditional" tables, and the NIPA bridge tables were referred to as "supplementary" tables.)

Taxes and license fees (ASM): Includes payments made to government agencies for business and property taxes and licensing fees. Income taxes are excluded from this item.

Temporary staff and leased employee expenses (ASM): Included in the cost of selected temporary staff and leased employee expenses are total costs which were paid directly by the establishment to Professional Employer Organizations (PEOs) and staffing agencies for personnel. These include all charges for payroll, benefits, and services.

Total BOY inventories (ASM): Respondents were asked to report their beginning of year and end of year inventories at cost or market. Effective with the 1982

Economic Census, this change to a uniform instruction for reporting inventories was introduced for all sector reports. Prior to 1982, respondents were permitted to value inventories using any generally accepted accounting method (FIFO, LIFO, or market, to name a few). Beginning in 1982, LIFO users were asked to first report inventory values prior to the LIFO adjustment and then to report the LIFO reserve and the LIFO value after adjustment for the reserve.

\section{Inventory data by stage of fabrication}

Total inventories and three detailed components were collected:

1. Finished goods 
2. Work-in-process

3. Materials, supplies, fuels, etc.

Materials inventories refer to goods that are raw inputs to the manufacturing process, and that will be substantially altered to produce an establishment's output. Work-in-process inventories refer to goods that have been substantially transformed in the manufacturing process, but that are not yet the final output of the establishment. Finished goods are goods that represent the final output of the establishment, but that are still within ownership of the establishment.

When using inventory data by stage of fabrication for "all industries" and at the three-digit subsector level, it should be noted that an item treated as a finished product by an establishment in one industry may be reported as a raw material by an establishment in a different industry. For example, the finished product inventories of a steel mill would be reported as raw materials by a stamping plant. Such differences are present in the inventory figures by stage of fabrication shown for all publication levels.

Total capital expenditures (new and used) (ASM): Represents the total new and used capital expenditures reported by establishments in operation and any known plants under construction.

These data include expenditures for:

1. Permanent additions and major alterations to manufacturing and mining establishments.

2. New and used machinery and equipment used for replacement and additions to plant capacity, if they are of the type for which depreciation, depletion, or (for mining establishments) Office of Minerals Exploration accounts are ordinarily maintained. In addition, for mining establishments, these data include expenditures made during the year for development and exploration of mineral properties. For manufacturing establishments, these data are broken down into three types:

a. Automobiles, trucks, etc. for highway use. These include vehicles acquired under a lease-purchase agreement and exclude vehicles leased or normally designed to transport materials, property, or equipment on mining, construction, petroleum development, and similar projects. These vehicles are of such size or weight as to be normally restricted by state laws or regulations from operating on public highways. Also excluded are vehicles that are purchased by a company for highway use.

b. Computers and peripheral data processing equipment. This item includes all purchases of computers and related equipment.

c. All other expenditures for machinery and equipment excluding automobiles and computer equipment. 
Capital expenditures include work done by contract, as well as by the establishment's own workforce.

These data exclude expenditures for land and mineral rights and cost of maintenance and repairs charged as current operating expenses.

Total cost of materials (ASM): This term refers to direct charges actually paid or payable for items consumed or put into production during the year, including freight charges and other direct charges incurred by the establishment in acquiring these materials. It includes the cost of materials or fuel consumed, whether purchased by the individual establishment from other companies, transferred to it from other establishments of the same company, or withdrawn from inventory during the year.

Included in this item are:

1. Cost of parts, components, containers, etc. Includes all raw materials, semifinished goods, parts, containers, scrap, and supplies put into production or used as operating supplies and for repair and maintenance during the year.

2. Cost of products bought and sold in the same condition.

3. Cost of fuels consumed for heat and power. Includes the cost of materials or fuel consumed, whether purchased by the individual establishment from other companies, transferred to it from other establishments of the same company, or withdrawn from inventory during the year.

4. Cost of purchased electricity. The cost of purchased electric energy represents the amount actually used during the year for heat and power. In addition, information was collected on the quantity of electric energy generated by the establishment and the quantity of electric energy sold or transferred to other plants of the same company.

5. Cost of contract work. This term applies to work done by others on materials furnished by the manufacturing establishment. The actual cost of the material is to be reported on the cost of materials, parts, and containers line of this item. The term "contract work" refers to the fee a company pays to another company to perform a service.

Aggregate of total cost of materials and total value of shipments includes extensive duplication, since products of some industries are used as materials of others.

Total depreciation (ASM): This item includes depreciation and amortization charged during the year against assets. Depreciation charged against fixed assets acquired since the beginning of the year and against assets sold or retired during the year are components of this category. Respondents were requested to make certain that they did not report accumulated depreciation.

Total EOY inventories (ASM): Respondents were asked to report their beginning of year and end of year inventories at cost or market. Effective with the 1982 Economic Census, this change to a uniform instruction for reporting inventories was 
introduced for all sector reports. Prior to 1982, respondents were permitted to value inventories using any generally accepted accounting method (FIFO, LIFO, or market, to name a few). Beginning in 1982, LIFO users were asked to first report inventory values prior to the LIFO adjustment and then to report the LIFO reserve and the LIFO value after adjustment for the reserve.

\section{Inventory data by stage of fabrication}

Total inventories and three detailed components were collected:

1. Finished goods

2. Work-in-process

3. Materials, supplies, fuels, etc.

Materials inventories refer to goods that are raw inputs to the manufacturing process, and that will be substantially altered to produce an establishment's output. Work-in-process inventories refer to goods that have been substantially transformed in the manufacturing process, but that are not yet the final output of the establishment. Finished goods are goods that represent the final output of the establishment, but that are still within ownership of the establishment.

When using inventory data by stage of fabrication for "all industries" and at the three-digit subsector level, it should be noted that an item treated as a finished product by an establishment in one industry may be reported as a raw material by an establishment in a different industry. For example, the finished product inventories of a steel mill would be reported as raw materials by a stamping plant. Such differences are present in the inventory figures by stage of fabrication shown for all publication levels.

Total Fringe Benefits (ASM): This item is the employer's costs for social security tax, unemployment tax, workers' compensation insurance, state disability insurance pension plans, stock purchase plans, union-negotiated benefits, life insurance premiums, and insurance premiums on hospital and medical plans for employees. Also included are the employer's costs for benefits to individual employees such as stock purchase plans, deferred profit-sharing plans, and defined benefit and defined contribution retirement plans. They exclude such items as company-operated cafeterias, in-plant medical services, free parking lots, discounts on employee purchases, and uniforms and work clothing for employees.

These figures represent the total amount of employer-paid benefits for all categories shown, and are inclusive of payments made on behalf of individuals that may not be included in the current payroll values . Consequently, for some manufacturing industries, payroll and benefits values may not move in tandem when compared to prior year tabulation totals. 
Note: Beginning with the 2006 ASM, for employment and related fields (payroll, production hours, benefits), respondents were asked to report only those full- and part-time employees whose payroll was reported on the IRS Form 941 filing for the Employer Identification Number (EIN) used by that manufacturing establishment. Other temporary workers and workers whose payroll was reported under a different company's EIN were reported elsewhere on the form. In 2002, these data constituted between 1 and 1 1/2\% of the total for these fields. Comparisons with data prior to 2006 should be used with caution.

Total misc. receipts (ASM): Miscellaneous receipts represent receipts from activities of the establishment other than the manufacturing of products from its own materials. Service activities such as installation, repair, and training are miscellaneous receipts. Assembly of products from materials owned by others and the sale of products bought and resold without further value added are other examples of miscellaneous receipts. Miscellaneous receipts are collected using the following categories:

1. Reported contract work - receipts for work or services that a plant performed for others on their materials.

2. Value of resales - sales of products bought and sold without further manufacture, processing, or assembly.

3. Other miscellaneous receipts - such as repair work, installation, sales of scrap, etc.

Total other expenses (ASM): Included in the total cost of other expenses are the totals for the following:

- Temporary staff and leased employee expenses

- Expensed computer hardware and other equipment

- Expensed purchases of software

- Data processing and other purchased computer services

- Communication services

- Repair and maintenance services of buildings and or machinery

- Refuse removal (including hazardous waste) services

- Advertising and promotional services

- Purchased professional and technical services

- Taxes and license fees

- All other expenses

Total rental payments (ASM): This item includes rental payments for the use of all items for which depreciation reserves would be maintained if they were owned by the establishment, e.g., structures and buildings, and production, office, and transportation equipment. Excluded are royalties and other payments for the use of intangibles and depletable assets and land rents where separable. 
When an establishment of a multiestablishment company was charged rent by another part of the same company for the use of assets owned by the company, it was instructed to exclude that cost from rental payments.

If there were assets at an establishment rented from another company and the rents were paid centrally by the head office of the establishment, the company was instructed to report these rental payments as if they were paid directly by the establishment.

Total requirements tables (BEA): Three I-O tables showing the output required to meet a given level of final use. The three tables are the commodity-by-commodity total requirements table, the industry-by-commodity total requirements table, and the industry-by-industry total requirements table. All three tables are calculated from the supplementary make and use tables.

Total value of shipments (ASM): This item covers the received or receivable net selling values, f.o.b. plant (exclusive of freight and taxes), of all products shipped as well as all miscellaneous receipts, such as receipts for contract work performed for others, installation and repair, sales of scrap, and sales of products bought and sold without further processing. Included are all items made by or for the establishments from material owned by it, whether sold, transferred to other plants of the same company, or shipped on consignment. The net selling value of products made in one plant on a contract basis from materials owned by another was reported by the plant providing the materials.

In the case of multiunit companies, the manufacturer was requested to report the value of products transferred to other establishments of the same company at full economic or commercial value, including not only the direct cost of production but also a reasonable proportion of "all other costs" (including company overhead) and profit.

Data represent total value of shipments for most industries. For industries 311411 , 311412, 311421, 311422, 311711, 311712, 311941, 311999, 312140, 312210, 312221 , and 312229 , value of production is shown. For industry 336611, value of work done is shown.

In addition to the value for NAICS-defined products, aggregates of the following categories of miscellaneous receipts are reported as part of a total establishment's value of products shipments:

1. Reported contract work - receipts for work or services that a plant performed for others on their materials;

2. Value of resales - sales of products bought and sold without further manufacture, processing, or assembly; and

3. Other miscellaneous receipts - includes repair work, installation, sales of scrap, etc. 
Use table (BEA): Matrix that shows the consumption of commodities by each industry or final user. The entries in a row represent the dollar value of the commodity consumed by each industry or final user. The total output of each commodity is the sum of all intermediate uses of the commodity by industries and all sales to final users, or the sum of the row entries. The entries in a column represent the dollar value of each commodity and value-added component used by the industry. The total output of each industry is the sum of all intermediate uses of all commodities and value added, or the sum of the column entries. For the economy as a whole, the total of all final uses of commodities equals the sum of all value added by all industries, or GDP. Use tables are produced for industries both before redefinitions and after redefinitions. It is one of the two primary tables in the I-O accounts. The use table, together with the make table, is used to derive the I-O total requirements tables.

Value added (ASM): This measure of manufacturing activity is derived by subtracting the cost of materials, supplies, containers, fuel, purchased electricity, and contract work from the value of shipments (products manufactured plus receipts for services rendered). The result of this calculation is adjusted by the addition of value added by merchandising operations (i.e., the difference between the sales value and the cost of merchandise sold without further manufacture, processing, or assembly) plus the net change in finished goods and work-in-process between the beginning and end of year inventories.

For those industries where value of production is collected instead of value of shipments, value added is adjusted only for the change in work-in-process inventories between the beginning and end of year. For those industries where value of work done is collected, the value added does not include an adjustment for the change in finished goods or work-in-process inventories.

This item avoids the duplication in the figure for value of shipments that results from the use of products of some establishments as materials by others. Value added is considered to be the best value measure available for comparing the relative economic importance of manufacturing among industries and geographic areas.

Value added (BEA): The difference between an industry's or an establishment's total output and the cost of its intermediate inputs. It equals gross output (sales or receipts and other operating income, plus inventory change) minus intermediate inputs (consumption of goods and services purchased from other industries or imported). Value added consists of compensation of employees, taxes on production and imports less subsidies (formerly indirect business taxes and nontax payments), and gross operating surplus (formerly "other value added"). 
Value added (OECD): The value added used by the OECD is stated to be consistent with that described in the 1993 System of National Accounts. ${ }^{92}$

Value added (UNSD): Gross value added is the value of output less the value of intermediate consumption; it is a measure of the contribution to GDP made by an individual producer, industry or sector; gross value added is the source from which the primary incomes of the System of National Accounts (SNA) are generated and is therefore carried forward into the primary distribution of income account.

Value of interplant transfers (ASM): In the case of multiunit companies, the manufacturer was requested to report the value of products transferred to other establishments of the same company at full economic or commercial value, including not only the direct cost of production but also a reasonable proportion of "all other costs" (including company overhead) and profit.

Value of products shipments (ASM): This item covers the received or receivable net selling values, f.o.b. plant (exclusive of freight and taxes), of all products shipped. Miscellaneous receipts, such as receipts for contract work performed for others, installation and repair, sales of scrap, and sales of products bought and sold without further processing are excluded from this item. Included are all items made by or for the establishments from material owned by it, whether sold, transferred to other plants of the same company, or shipped on consignment. The net selling value of products made in one plant on a contract basis from materials owned by another was reported by the plant providing the materials.

In the case of multiunit companies, the manufacturer was requested to report the value of products transferred to other establishments of the same company at full economic or commercial value, including not only the direct cost of production but also a reasonable proportion of "all other costs" (including company overhead) and profit.

Data represent total value of shipments for most industries. For industries 311411 , 311412, 311421, 311422, 311711, 311712, 311941, 311999, 312140, 312210, 312221 , and 312229 , value of production is shown. For industry 336611 , value of work done is shown.

Value of resales (ASM): Miscellaneous receipts represent receipts from activities of the establishment other than the manufacturing of products from its own materials. Service activities such as installation, repair, and training are miscellaneous receipts. Assembly of products from materials owned by others and the sale of products bought and resold without further value added are other examples of miscellaneous receipts. Miscellaneous receipts are collected using the following categories:

\footnotetext{
${ }^{92}$ Yamano, Norihiko and Nadim Ahmad. (2006) “The OECD Input-Output Database: 2006 Edition.” STI Working Paper 2006/8. Organisation for Economic Co-operation and Development. October 20, 2006. <http://www.oecd.org/dataoecd/46/54/37585924.pdf>
} 
1. Reported contract work - receipts for work or services that a plant performed for others on their materials.

2. Value of resales - sales of products bought and sold without further manufacture, processing, or assembly.

3. Other miscellaneous receipts - such as repair work, installation, sales of scrap, etc.

Volume of Production (Figure 4.5): This item is the sum of all expenditures shown in Figure 4.5, including communication services; other costs; refuse removal; computer hardware, software, and other equipment; professional, technical, and data services; payroll and benefits; capital expenditures: Buildings and other structures; capital expenditures: machinery and equipment; materials, parts, containers, packaging, etc. used; contract work and resales; and purchased fuels and electricity.

Work-in- process inventories, BOY (ASM): Respondents were asked to report their beginning of year and end of year inventories at cost or market. Effective with the 1982 Economic Census, this change to a uniform instruction for reporting inventories was introduced for all sector reports. Prior to 1982, respondents were permitted to value inventories using any generally accepted accounting method (FIFO, LIFO, or market, to name a few). Beginning in 1982, LIFO users were asked to first report inventory values prior to the LIFO adjustment and then to report the LIFO reserve and the LIFO value after adjustment for the reserve.

Inventory data by stage of fabrication

Total inventories and three detailed components were collected:

1. Finished goods

2. Work-in-process

3. Materials, supplies, fuels, etc.

Materials inventories refer to goods that are raw inputs to the manufacturing process, and that will be substantially altered to produce an establishment's output. Work-in-process inventories refer to goods that have been substantially transformed in the manufacturing process, but that are not yet the final output of the establishment. Finished goods are goods that represent the final output of the establishment, but that are still within ownership of the establishment.

When using inventory data by stage of fabrication for "all industries" and at the three-digit subsector level, it should be noted that an item treated as a finished product by an establishment in one industry may be reported as a raw material by an establishment in a different industry. For example, the finished product inventories of a steel mill would be reported as raw materials by a stamping plant. Such differences are present in the inventory figures by stage of fabrication shown for all publication levels. 
Work-in- process inventories, EOY (ASM): Respondents were asked to report their beginning of year and end of year inventories at cost or market. Effective with the 1982 Economic Census, this change to a uniform instruction for reporting inventories was introduced for all sector reports. Prior to 1982, respondents were permitted to value inventories using any generally accepted accounting method (FIFO, LIFO, or market, to name a few). Beginning in 1982, LIFO users were asked to first report inventory values prior to the LIFO adjustment and then to report the LIFO reserve and the LIFO value after adjustment for the reserve.

\section{Inventory data by stage of fabrication}

Total inventories and three detailed components were collected:

1. Finished goods

2. Work-in-process

3. Materials, supplies, fuels, etc.

Materials inventories refer to goods that are raw inputs to the manufacturing process, and that will be substantially altered to produce an establishment's output. Work-in-process inventories refer to goods that have been substantially transformed in the manufacturing process, but that are not yet the final output of the establishment. Finished goods are goods that represent the final output of the establishment, but that are still within ownership of the establishment.

When using inventory data by stage of fabrication for "all industries" and at the three-digit subsector level, it should be noted that an item treated as a finished product by an establishment in one industry may be reported as a raw material by an establishment in a different industry. For example, the finished product inventories of a steel mill would be reported as raw materials by a stamping plant. Such differences are present in the inventory figures by stage of fabrication shown for all publication levels. 